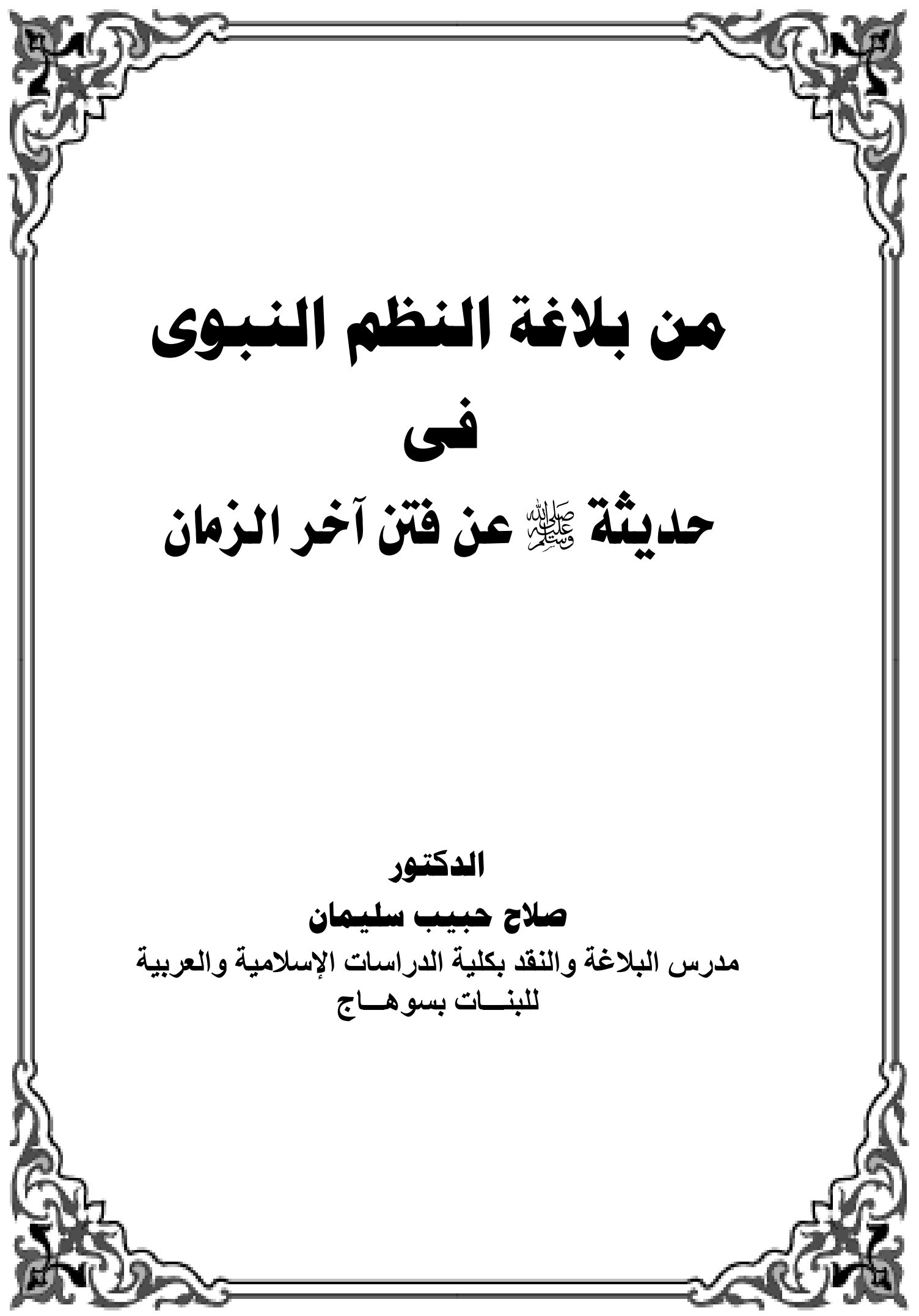




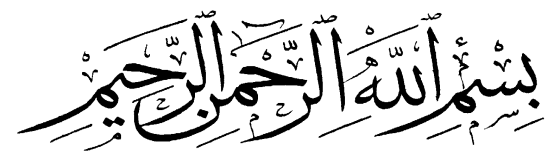

\section{هقدمهة البحـث}

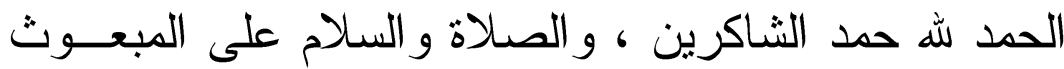

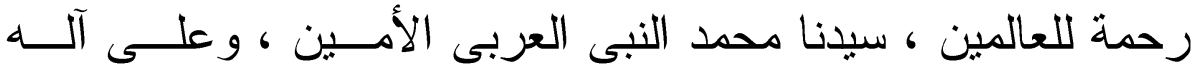

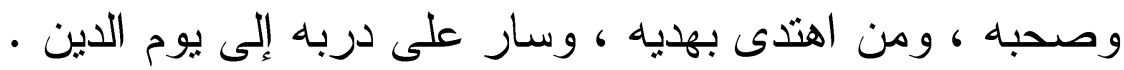

\section{وبنديد}

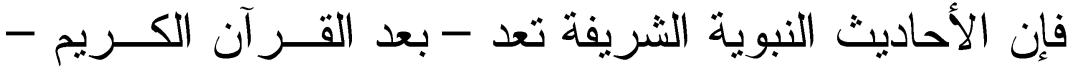

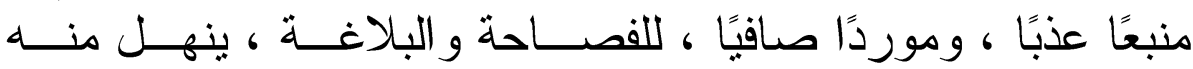

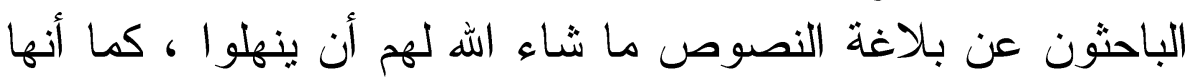

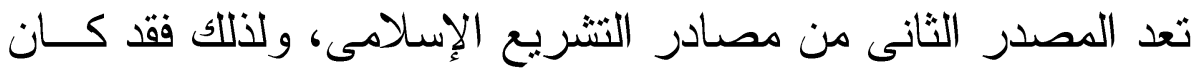

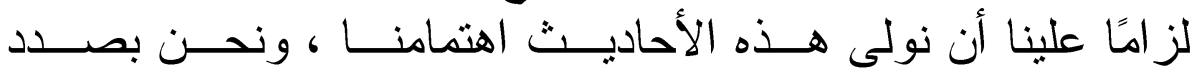

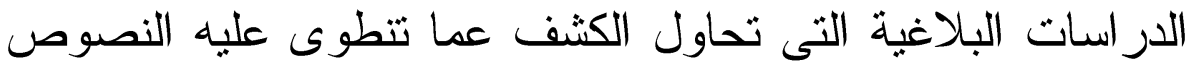

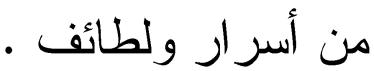

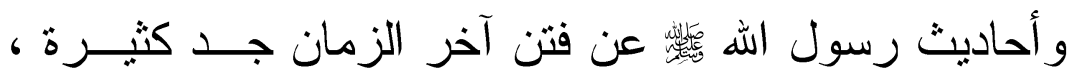

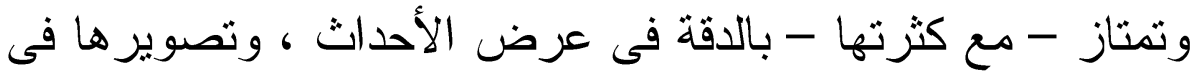

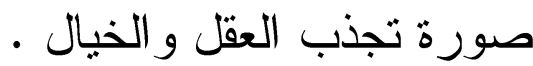

وكان مما جذب انتباهى ، و أنا أنصفح أحاديث رسول اله له

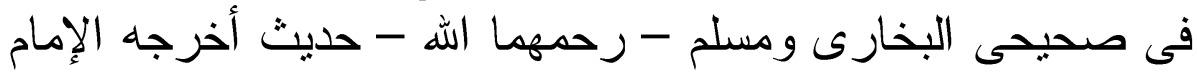

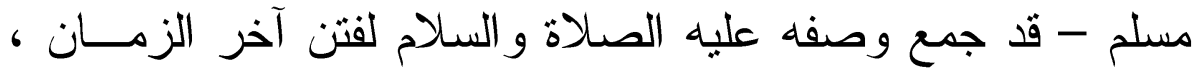

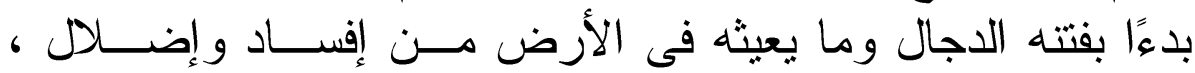

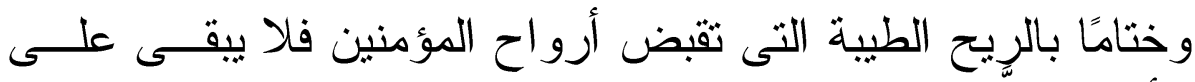

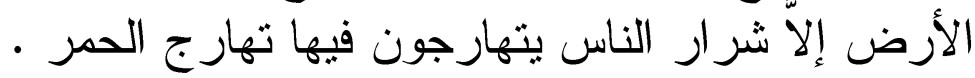




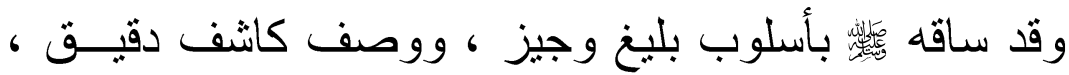

يجعل الخيال يتمثل هذه الأحداث وكأنها و اقعة مشاهدة .

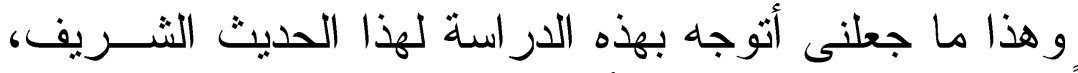

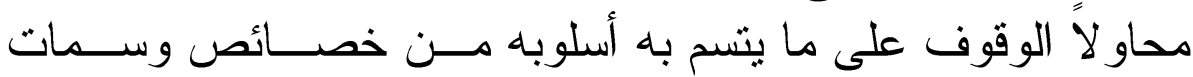

بلاغية.

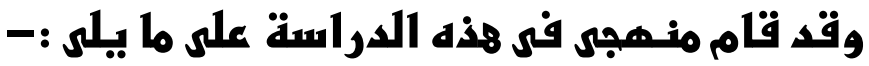

أولاً: التقديم للحديثث الشريف بما يبين المكانة البلاغبـــة للأحاديـــث

النبوية عمومًا ، ولهذا الحديث على وجه الخصوص .

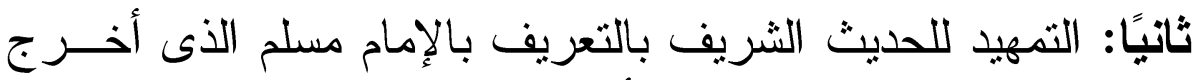

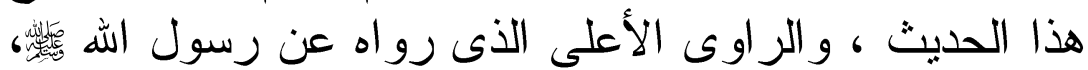

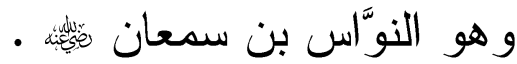

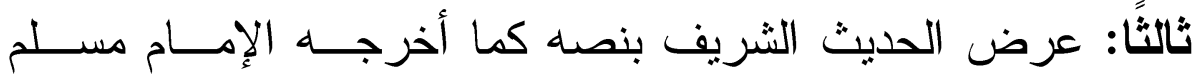

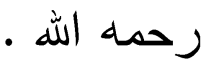

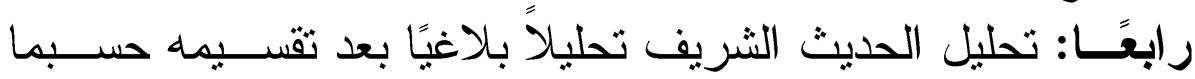

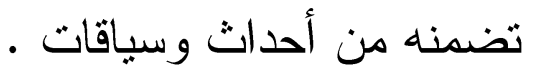

خامستا: خاتمه البحث ، و التى تضمنت الإشارة إلى أهم النتائج التى

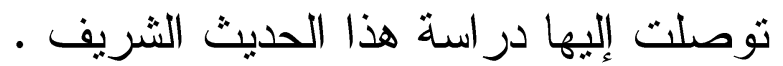

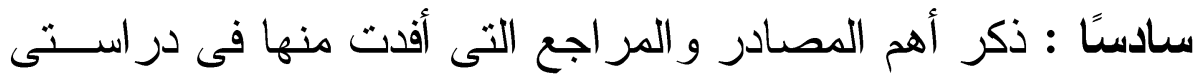

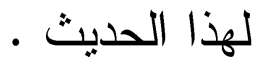

والله أسـأل أن ينفعنى بهذا العمل وينفع به 

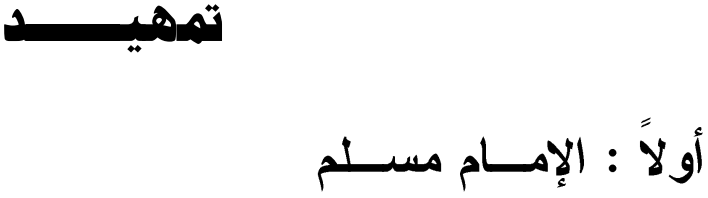

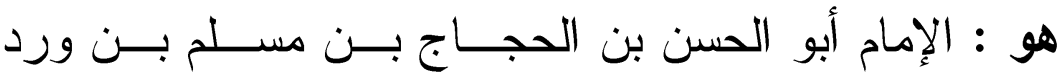

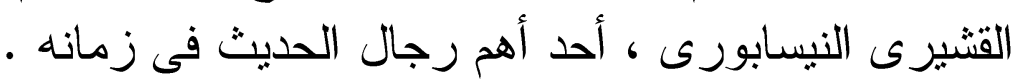

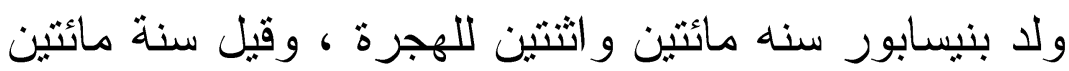

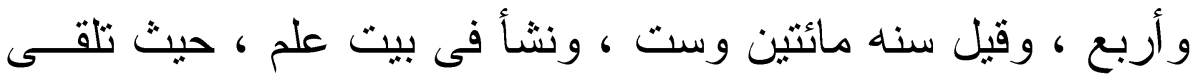

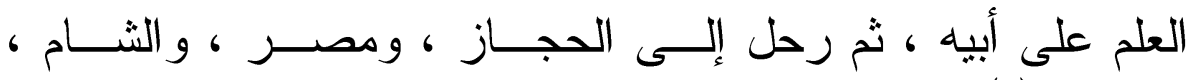
و العراق. (')

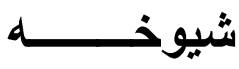

تتلمذ الإمام مسلم على يد العديد من علماء الحديث ، و الفقه،

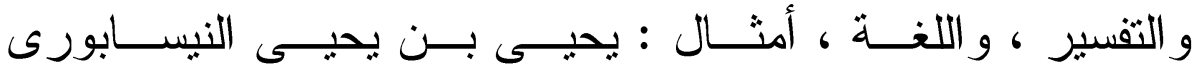

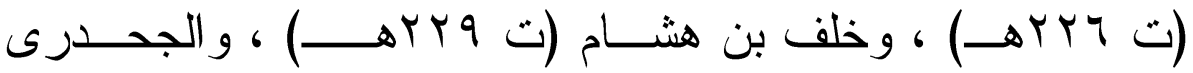

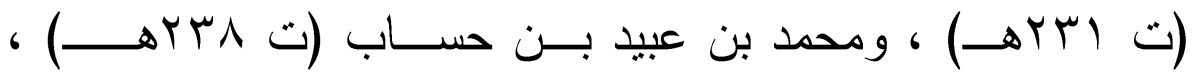

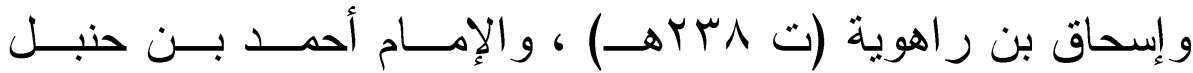

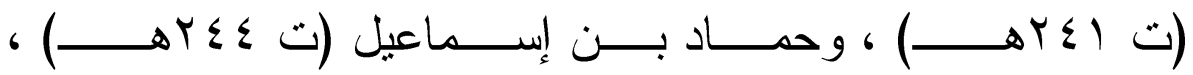

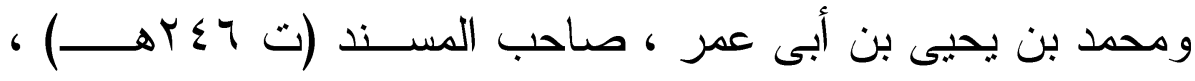

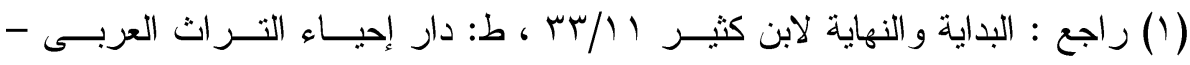

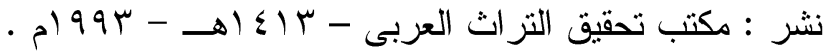

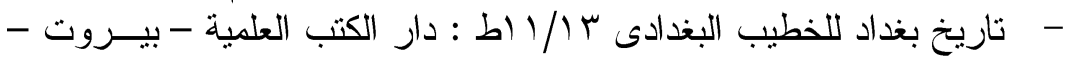

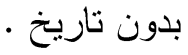

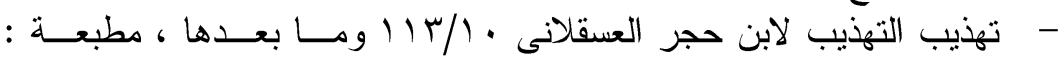

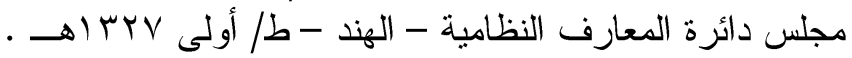

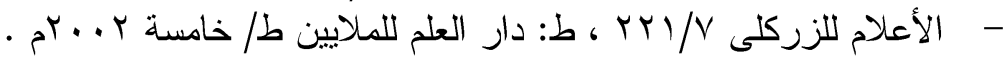


و الفضل بن سهل البغدادى (ت ب00 بهــ) ، والإمام الحافظ محمـــ

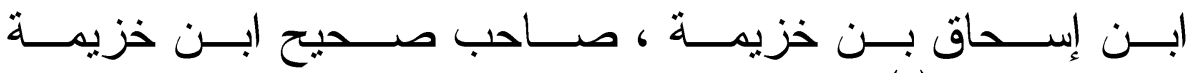

(l). (ت البن (1)

تلامذت

تلفذ على يديه العديد من علماء الحديث و الراوية ، نــذكر

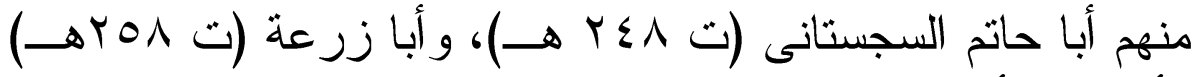

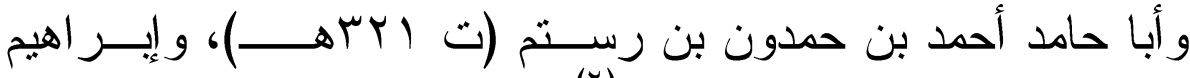

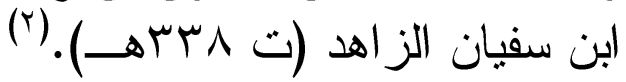

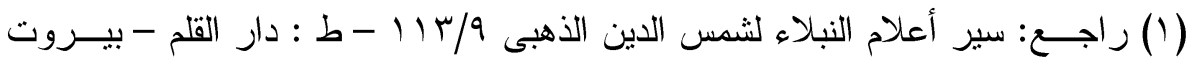

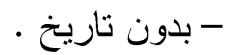

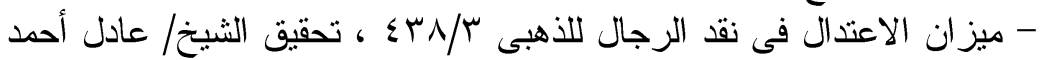

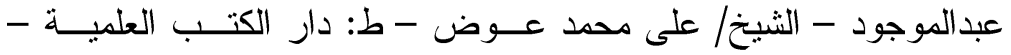

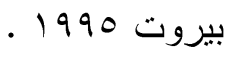

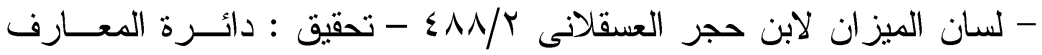

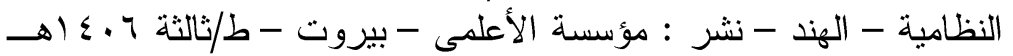

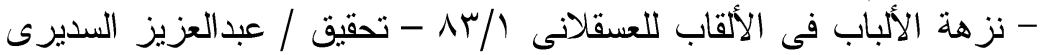

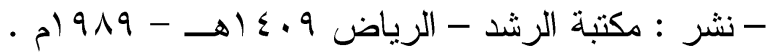

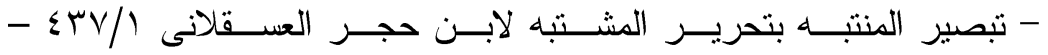

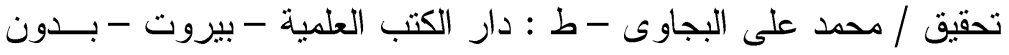
ن تاريخ

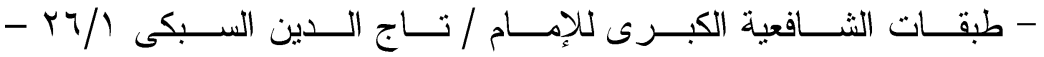

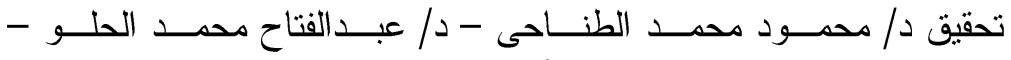

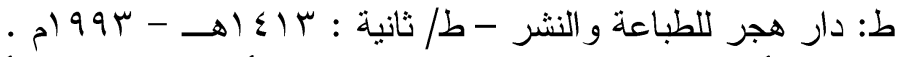

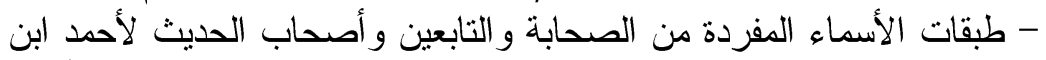

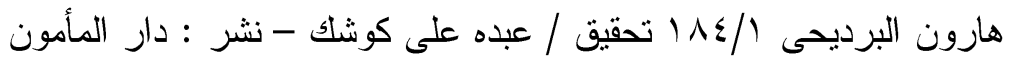

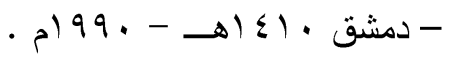

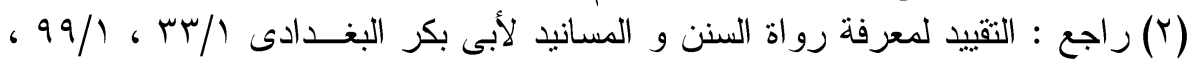

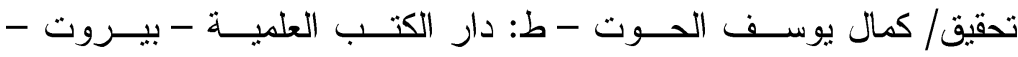

$$
\text { . } 9191-1 \leq
$$




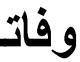

توفى الإمام مسلم - رحمه الله - بنيسابور ليلة الأحد لخمس

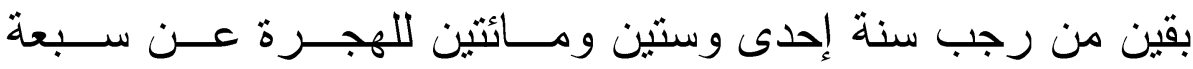

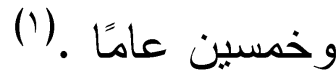

\section{مؤلقاتــهـ}

خلف الإمام مسلم لطلاب العلم الكثير من المصنفات النافعة، وكتب العلم القيمة ، منها : الصحيح ، و الذى جمع فيه اثنى عشــر

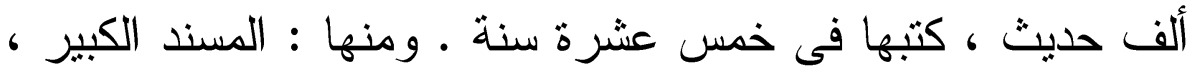

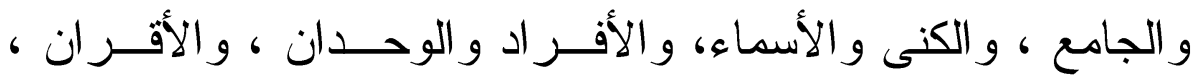

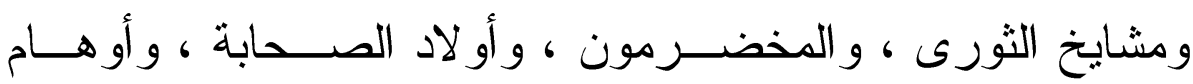

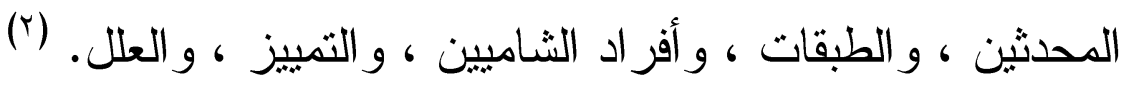
ثنانيًا : النَّوََّسُ بنُْ سَمْعَانَ

هو النََّّاسُ - بفتح النون و الواو المشــددتين - ابــن ســمعان

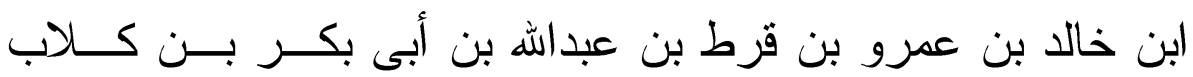

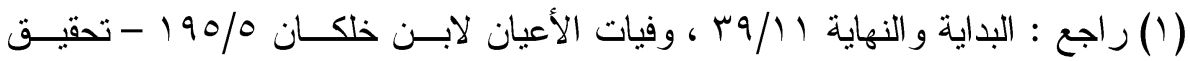

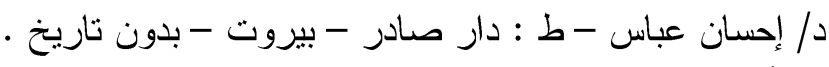

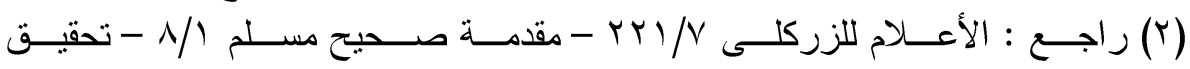

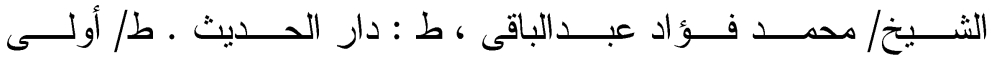

. $199 V-\rightarrow 1 \leqslant 11$ 
ابن ربيعة بن عامر بن صعصعة العامرى الكلابى ، معـدود فـى • الشاميين

صحابى جليل ، كان له و لأبيه صحبة ، فروى عن رســول ،

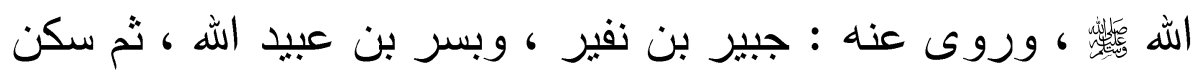

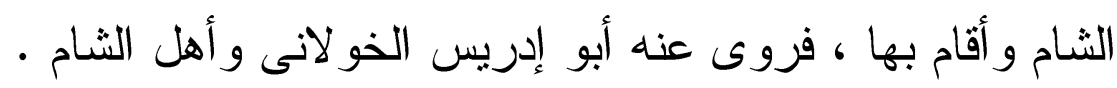

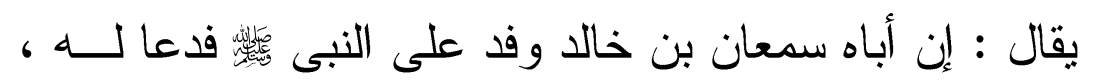

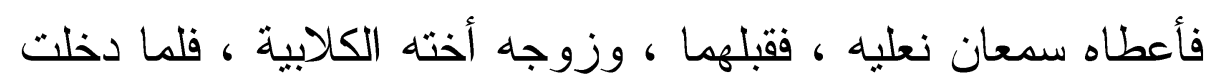
على النبى

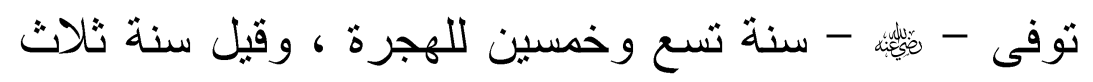
وخمسين ، وكان له - رحمه اله - ثناث وسنون سنة . (') وخدين

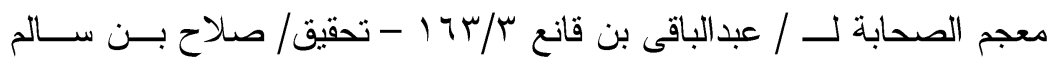

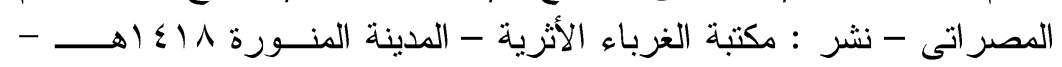

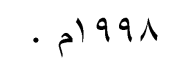

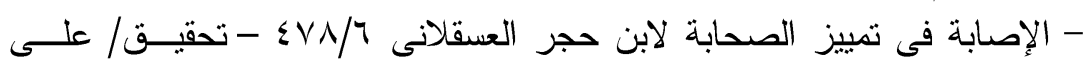

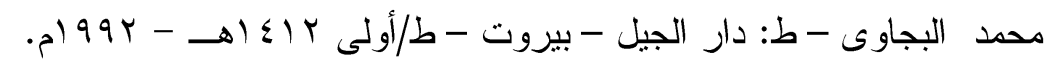

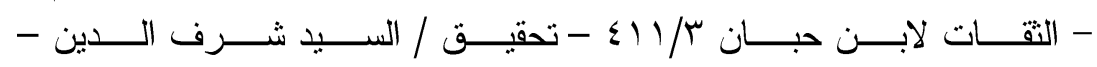

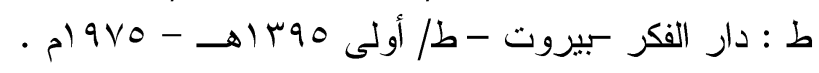

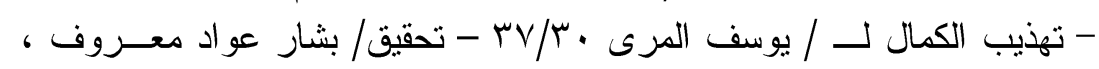

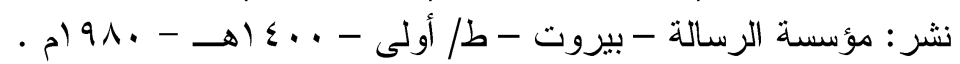

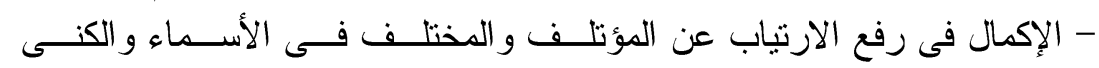

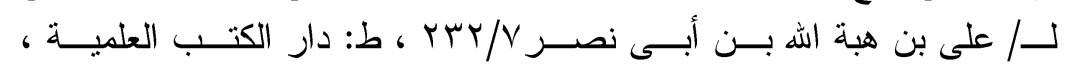

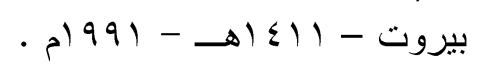




\section{نم المدبث الشربه}

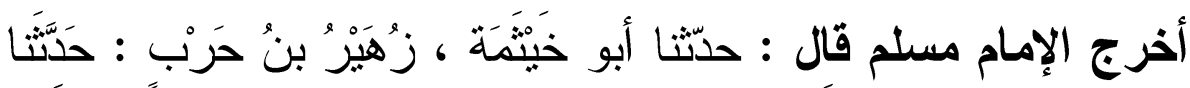

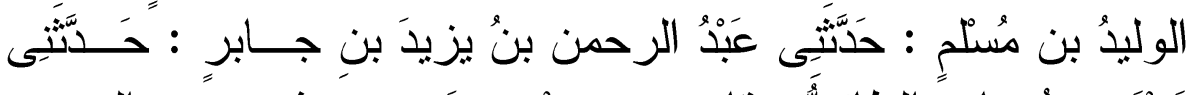

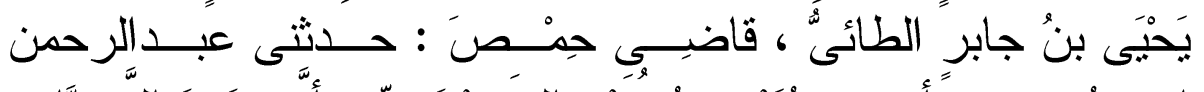

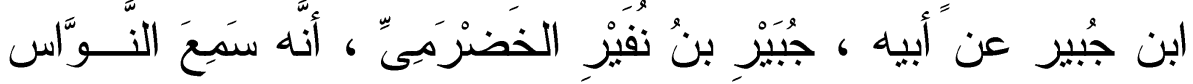

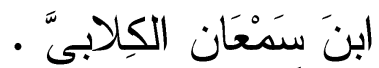

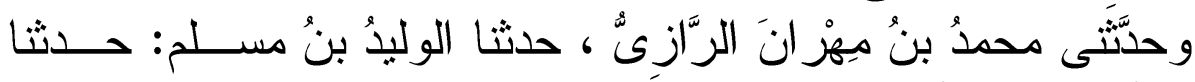

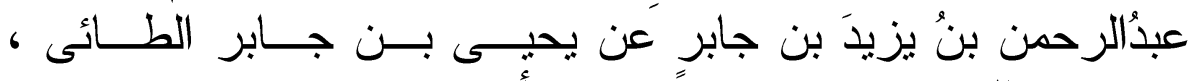

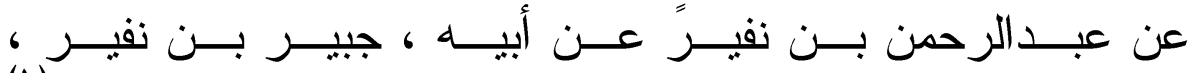

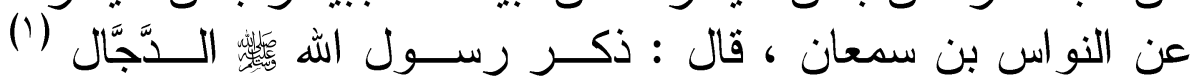

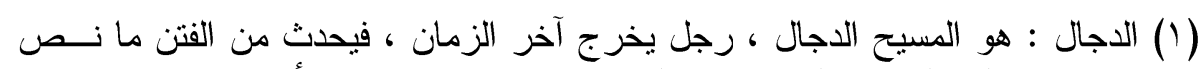

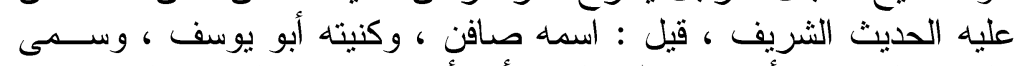

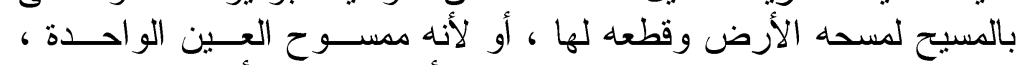

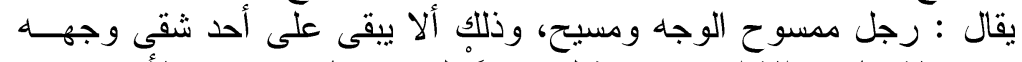

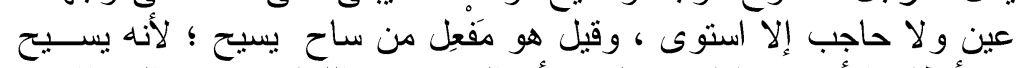

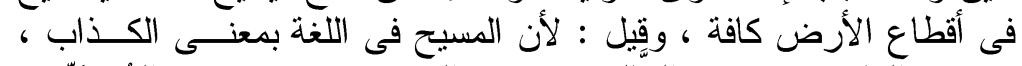

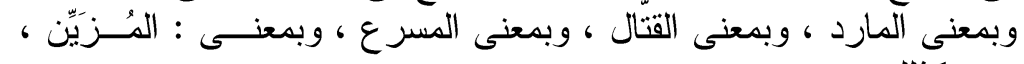

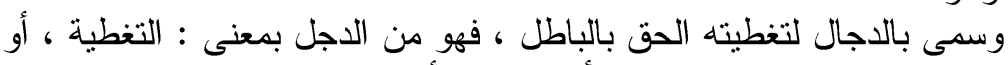

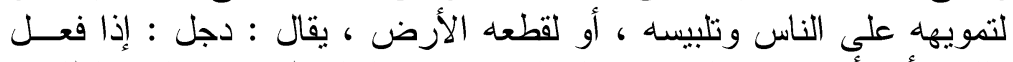

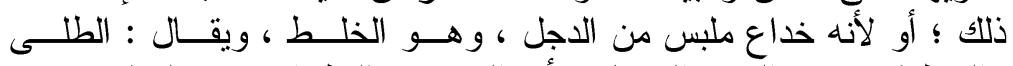

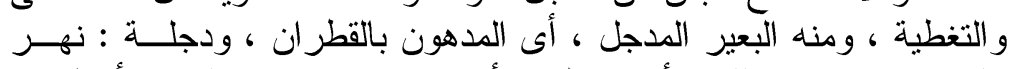

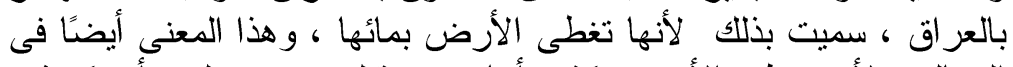

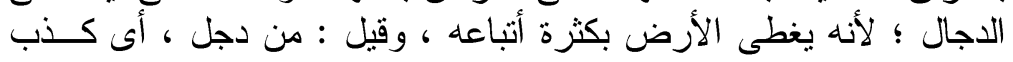

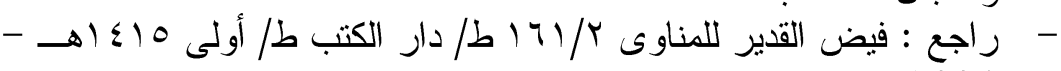
. 1992

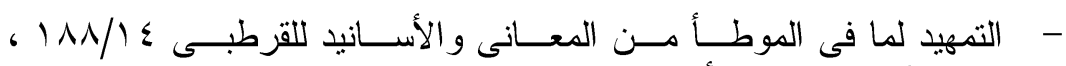

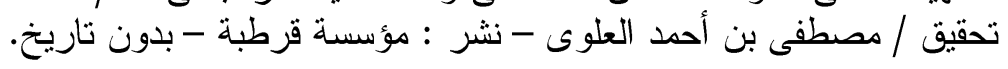




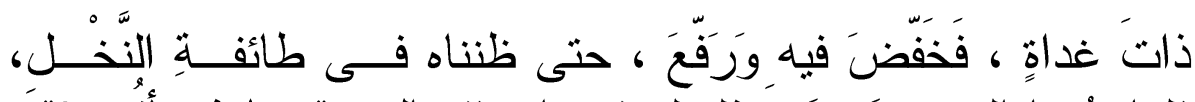

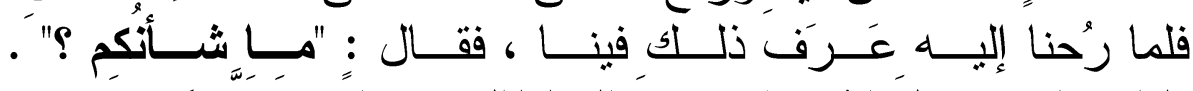

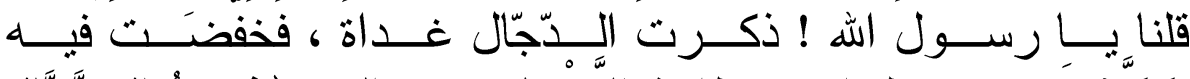

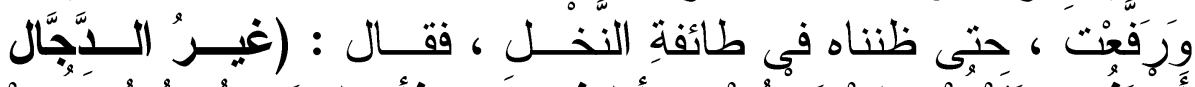

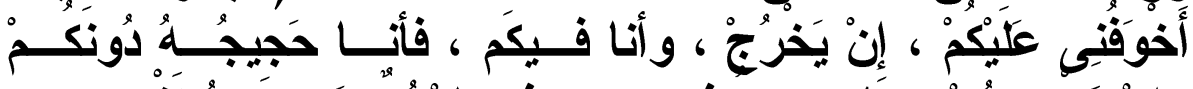

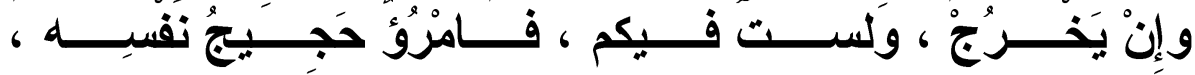

= - - الفائق للزمخشرى (مسح) تحقيق / على محمد البجاوى - محمد أبو الفضل دائل

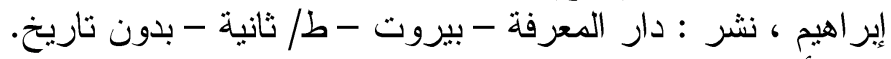

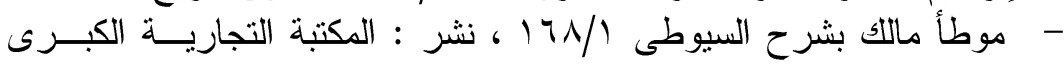

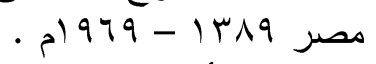

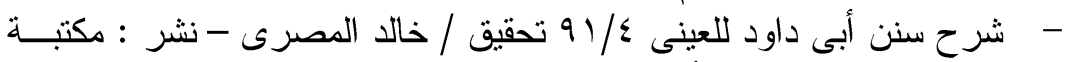

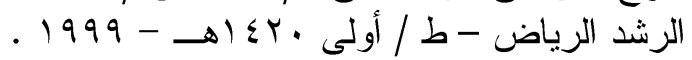

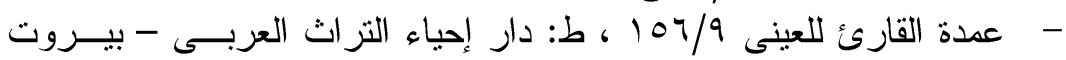

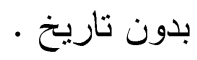

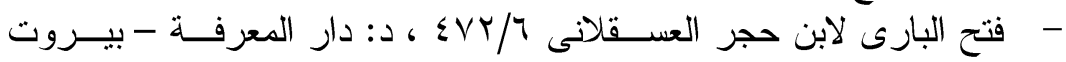

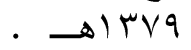

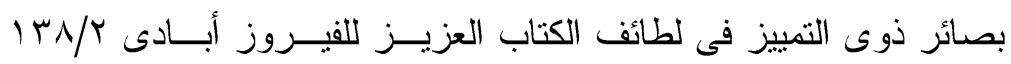

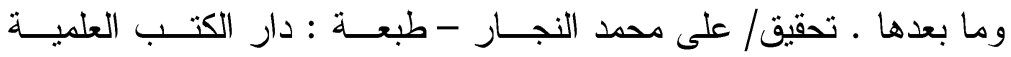

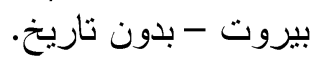

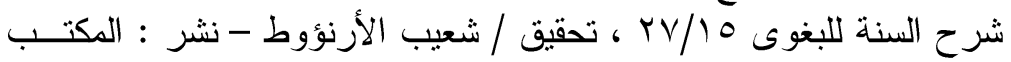

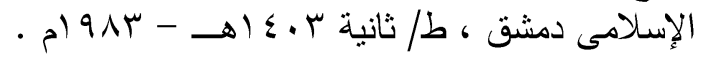

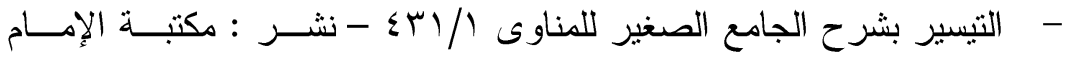

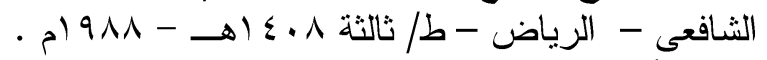

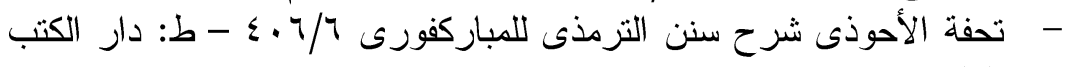

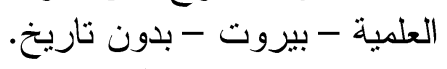

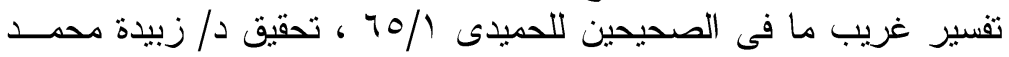

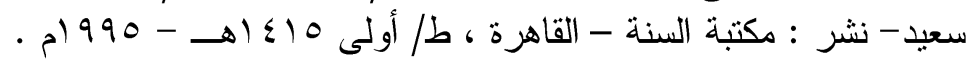

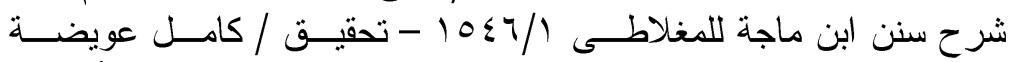

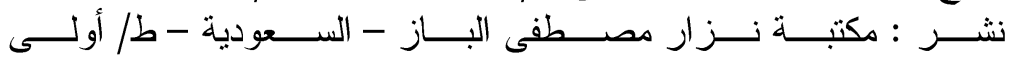

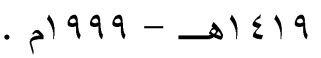

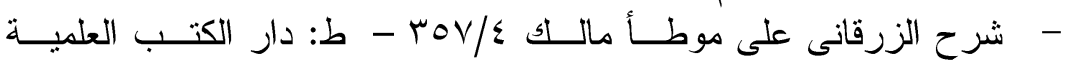
بيروت - بدون تاريخ. 


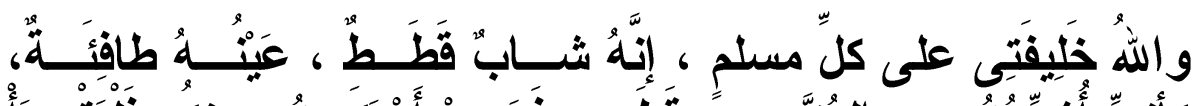

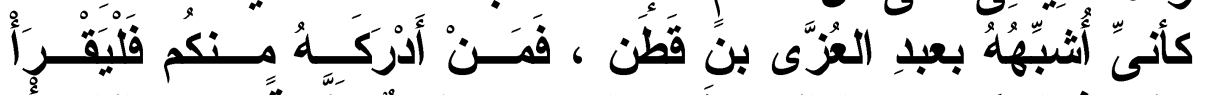

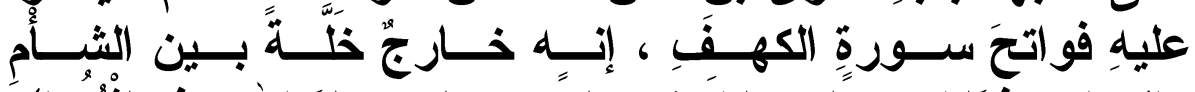

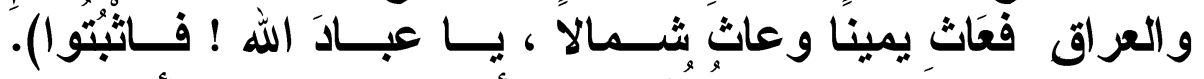

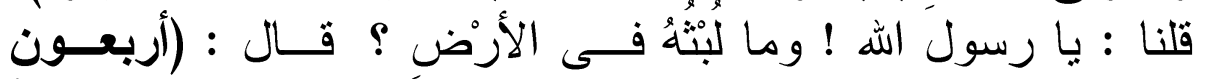

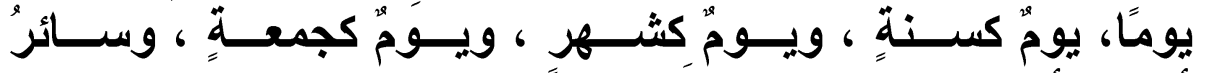

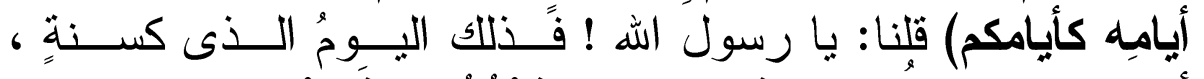

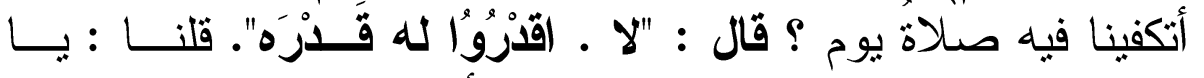

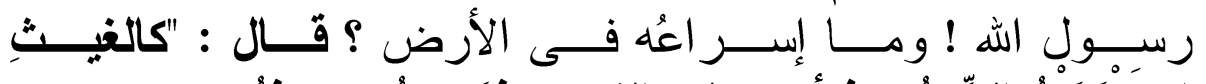

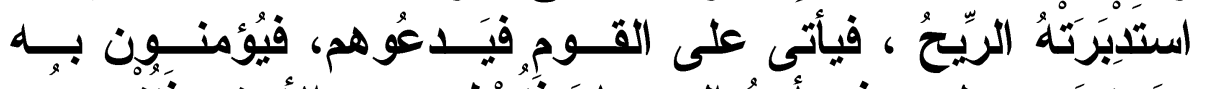

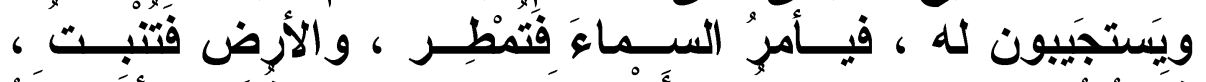

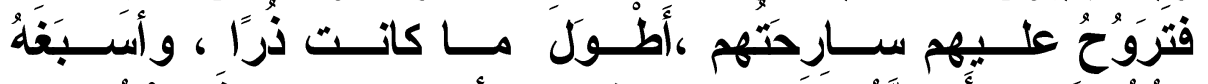

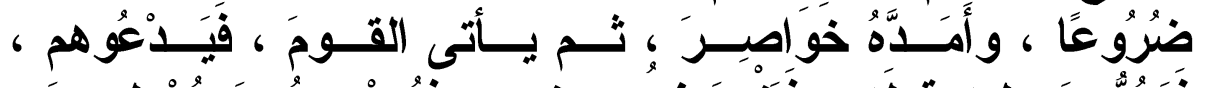

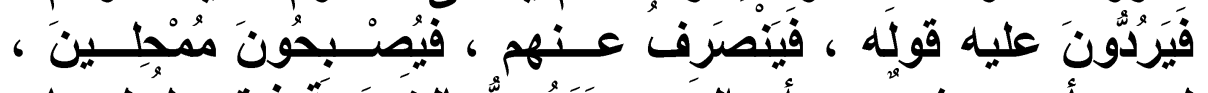

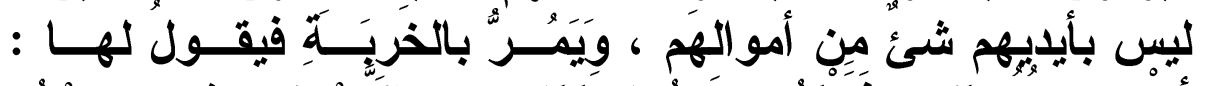

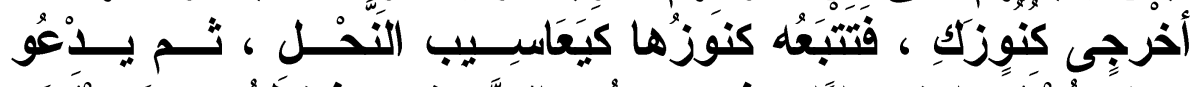

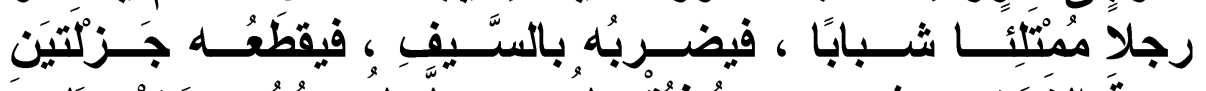

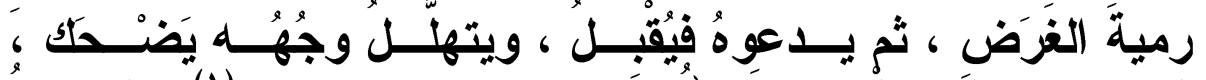

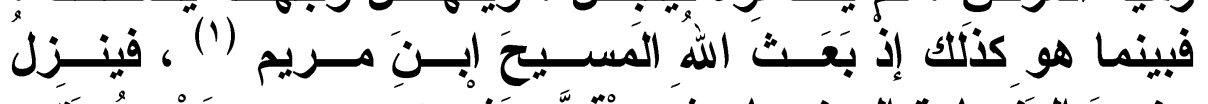

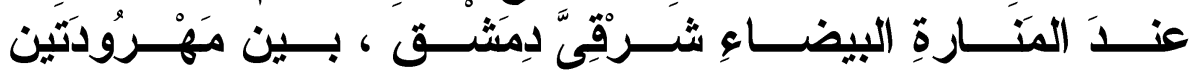

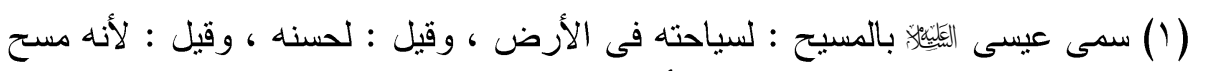

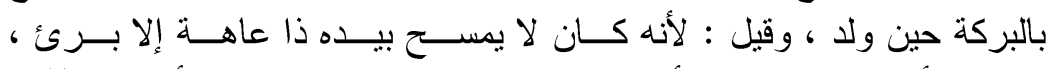

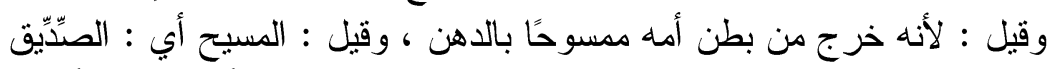

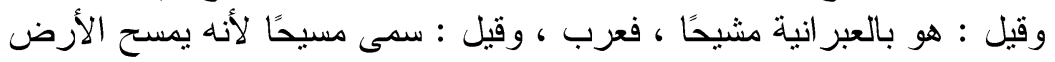

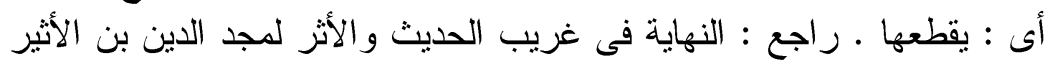

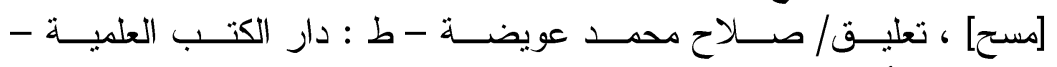

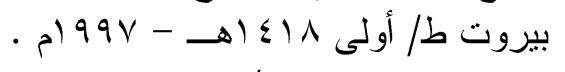

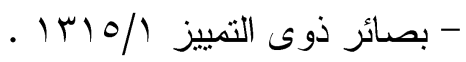




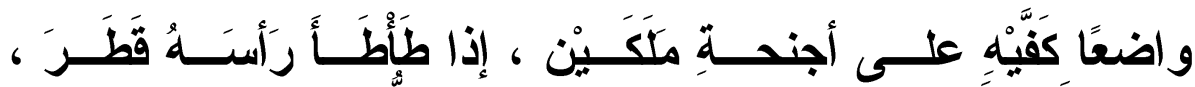

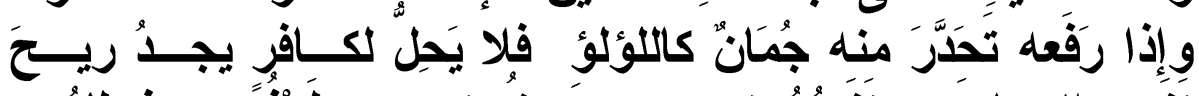

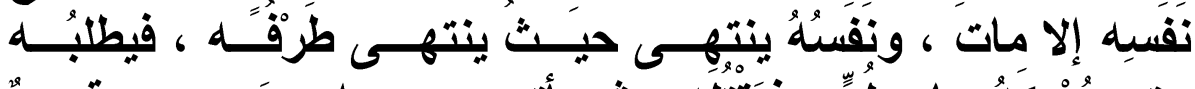

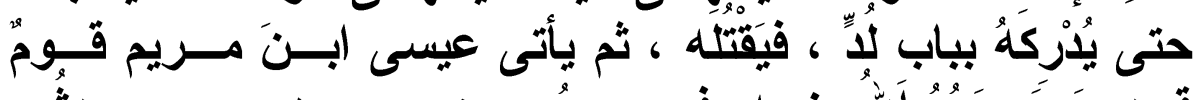

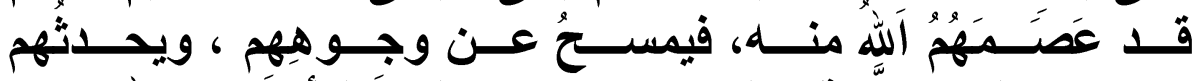

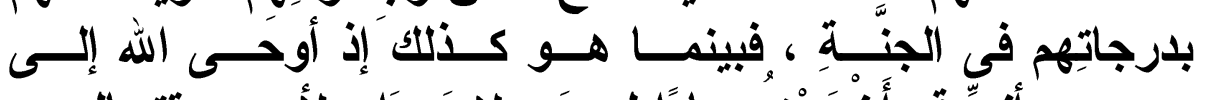

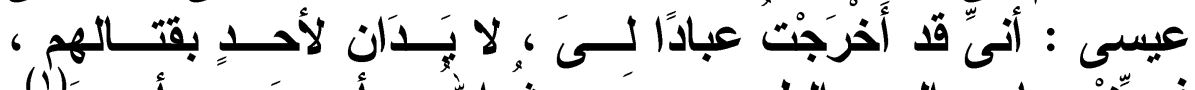

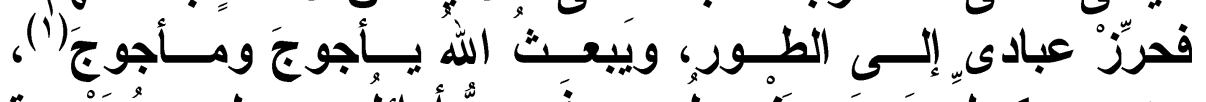

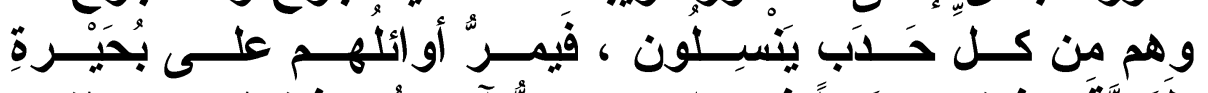

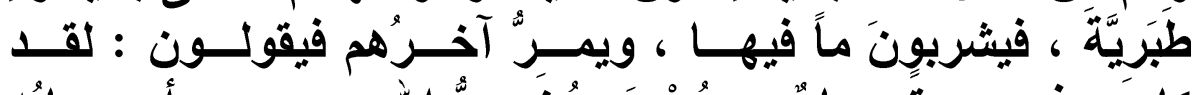

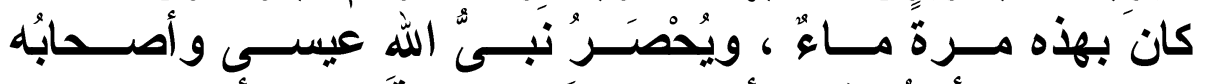

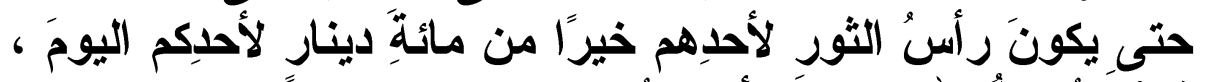

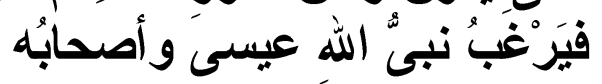

(1) يأجوج ومأجوج : قيل هم من ولا يافث بن نوح ، موجودون خلف السد الــــى بنــاه

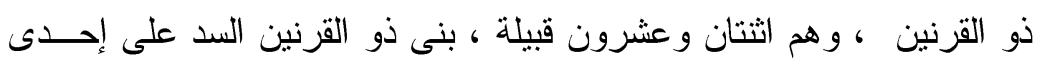

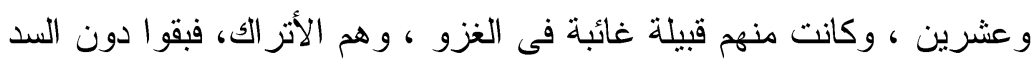

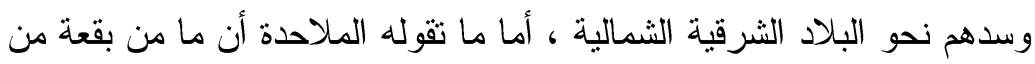

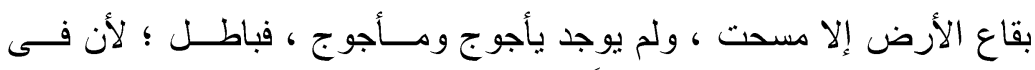

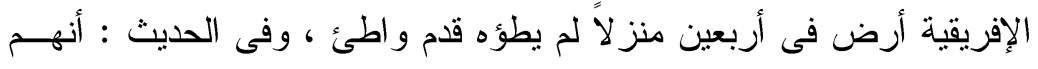

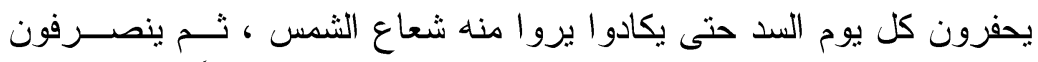

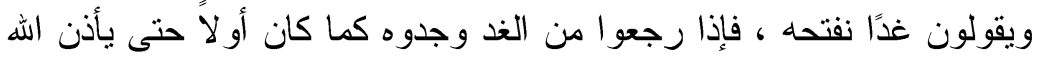

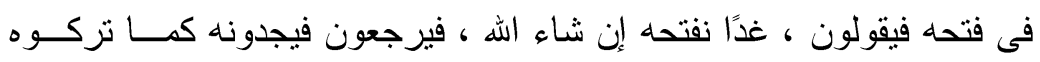

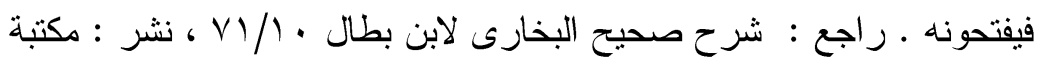

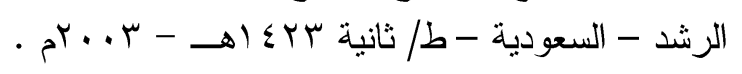

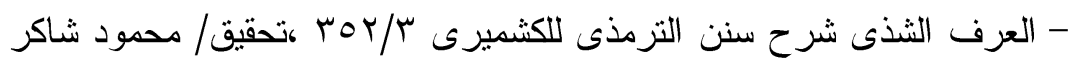

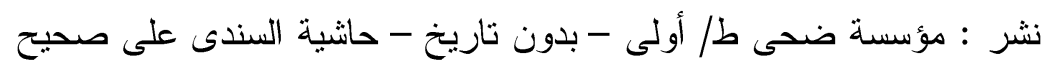

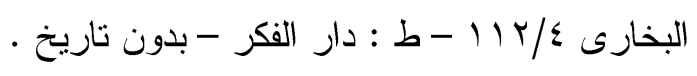




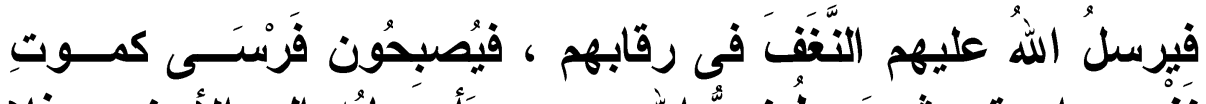

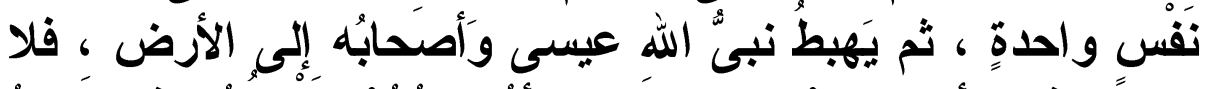

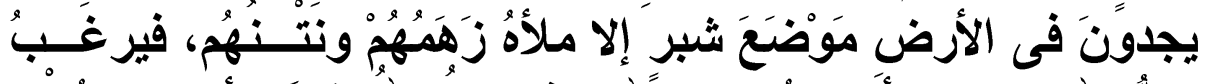

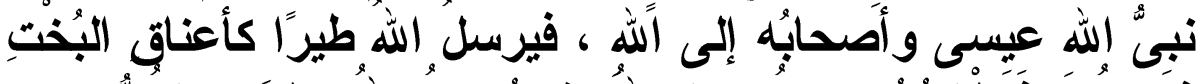

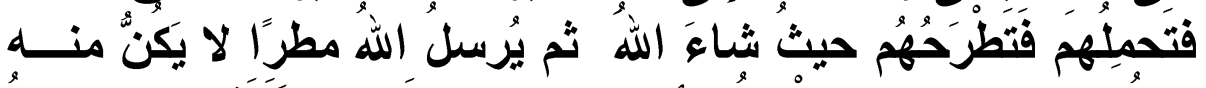

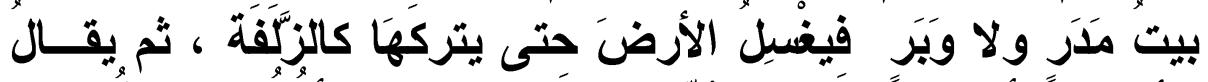

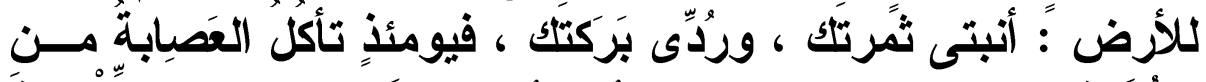

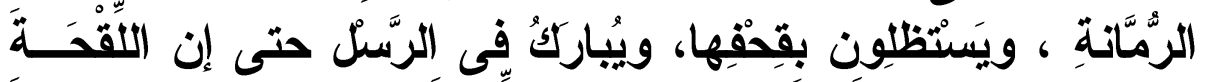

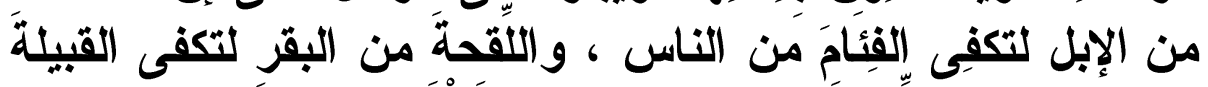

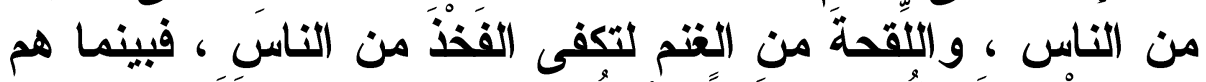

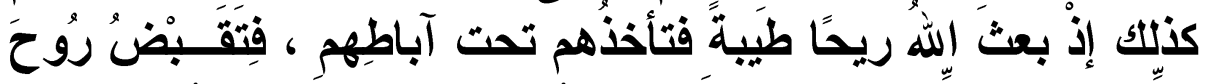

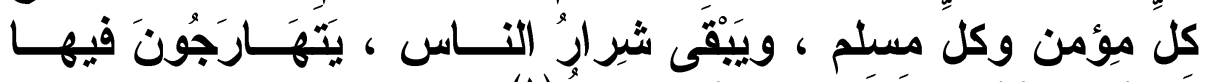

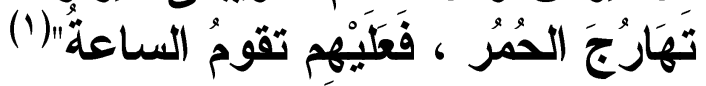

(1) راجع نص الحديث فى صحيح مسلم . ك : الفتن وأثر اط الساعة ، ب: ذكر الدجال

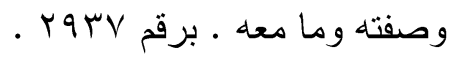

- وصحيح مسلم بشرح النووى MYT/9 وما بعدها ، نشر : مكتبــة الإيمسان -

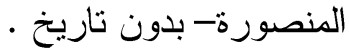


-YOYA-
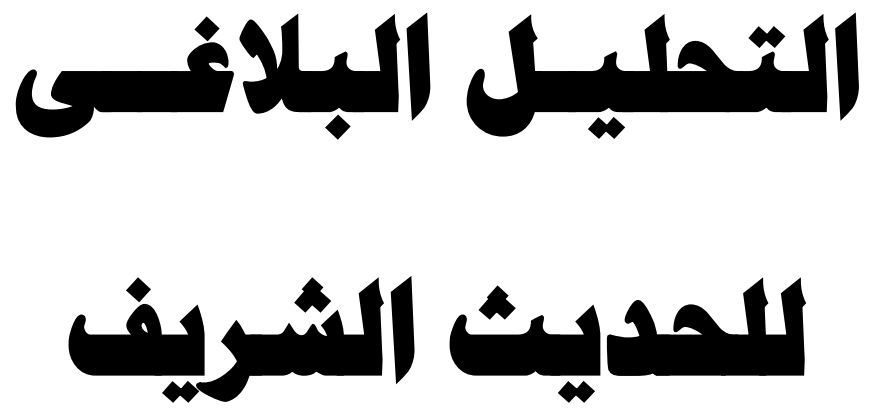


\section{وصفه}

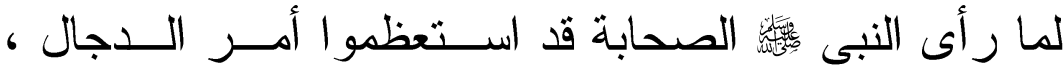

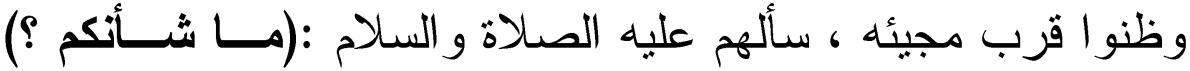

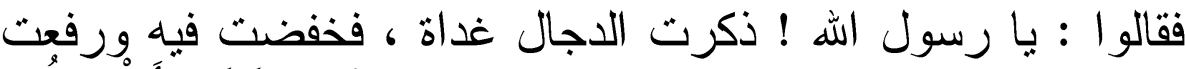

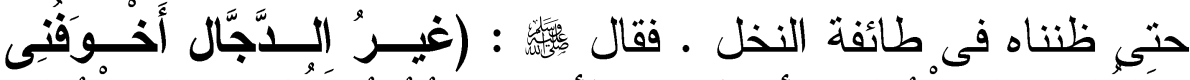

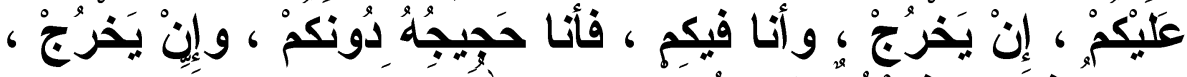

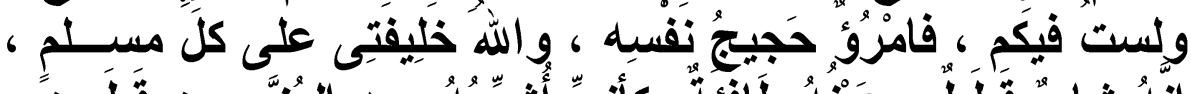

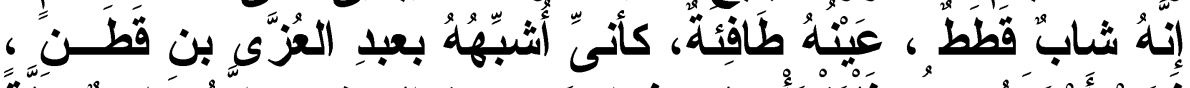

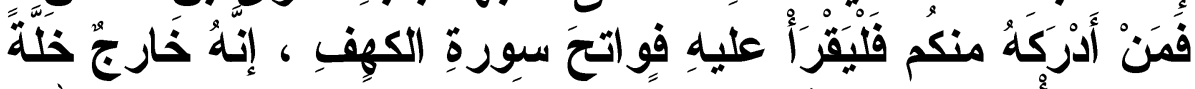

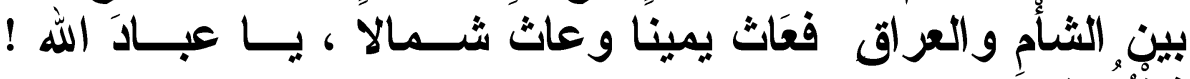

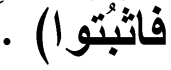

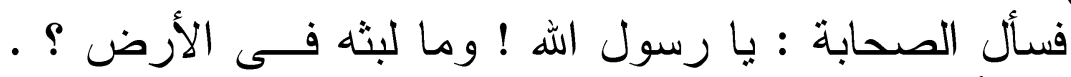

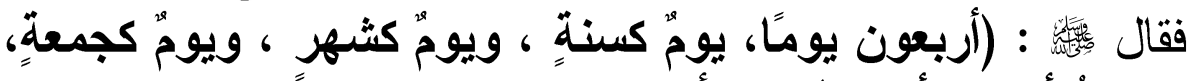

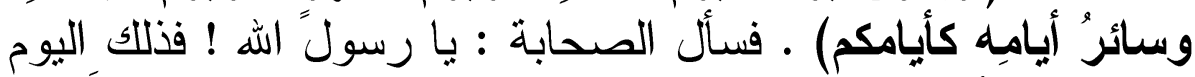

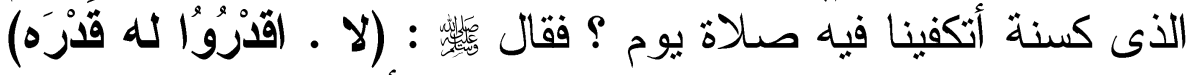

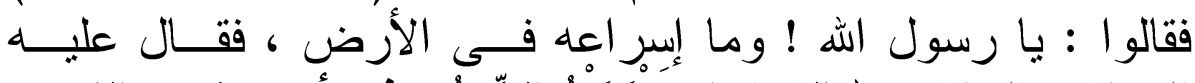

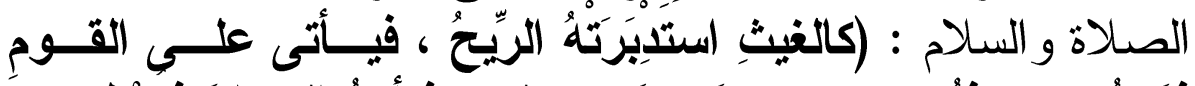

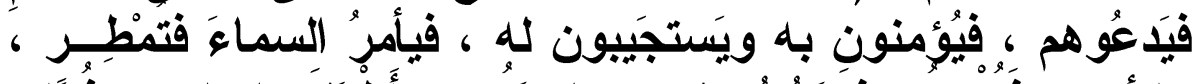

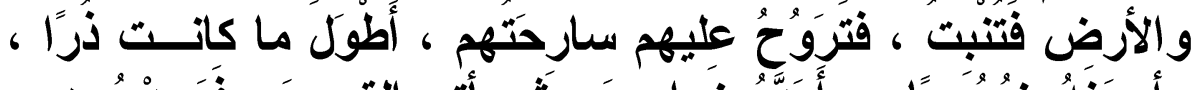

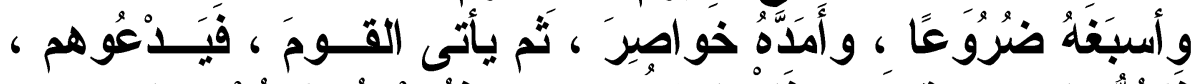

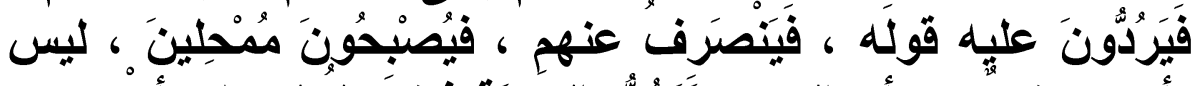

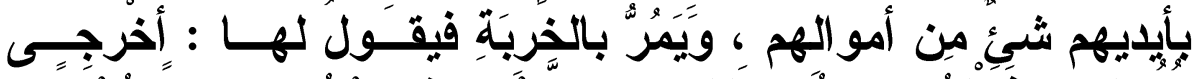

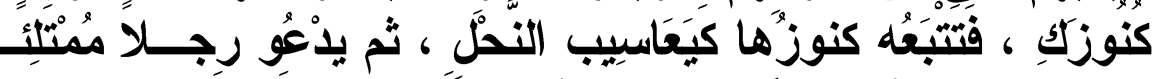

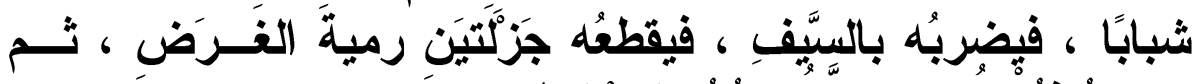

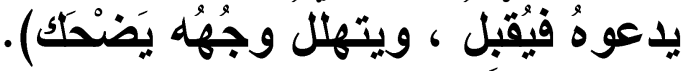




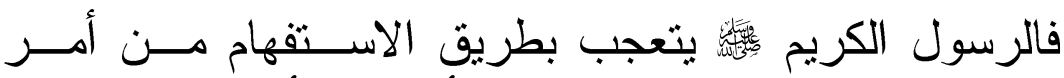

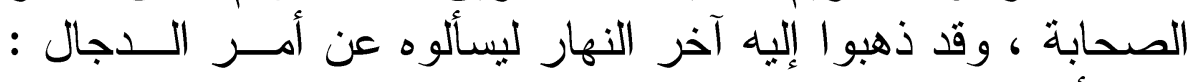

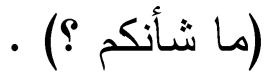

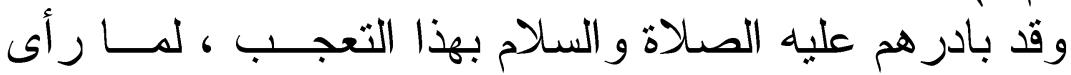

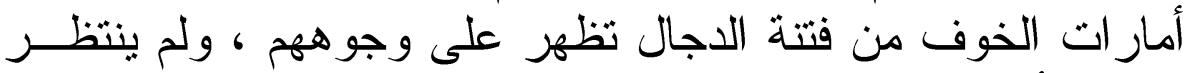

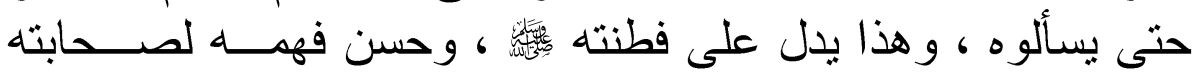

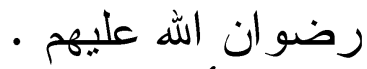

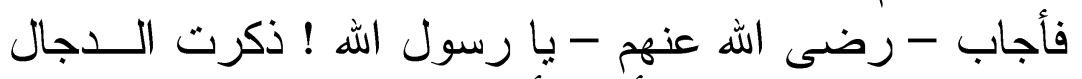

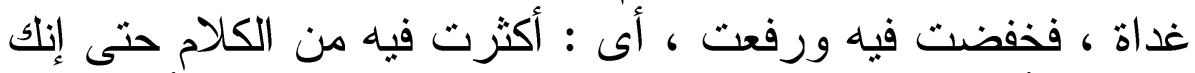

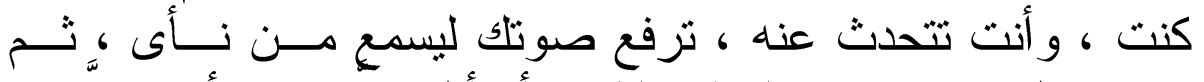

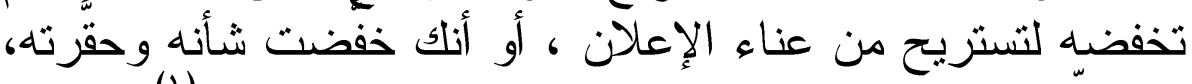

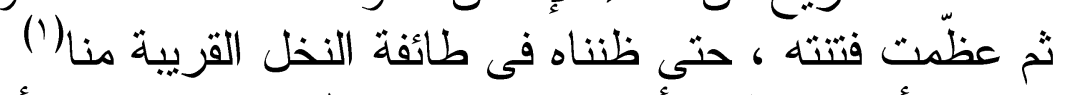

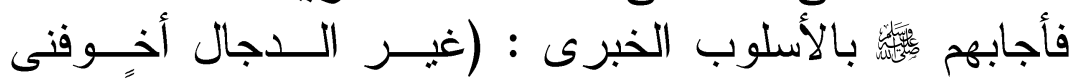

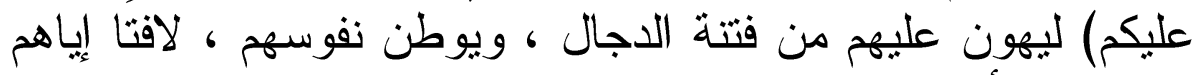

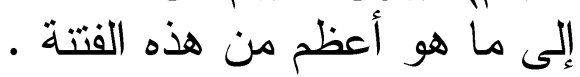

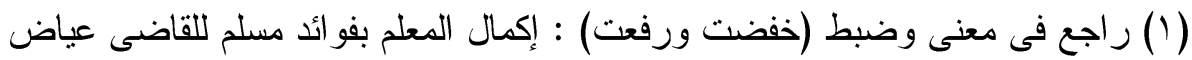

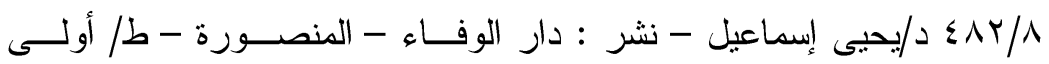

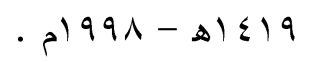

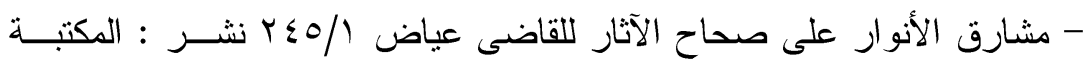

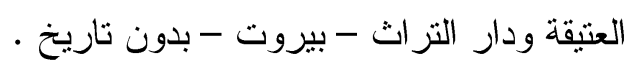

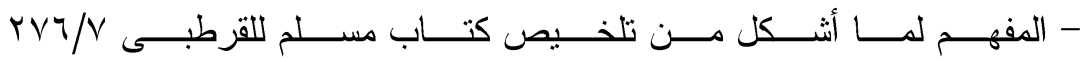

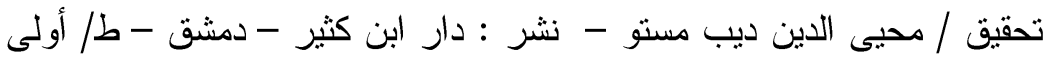

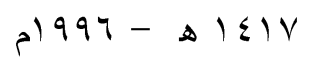

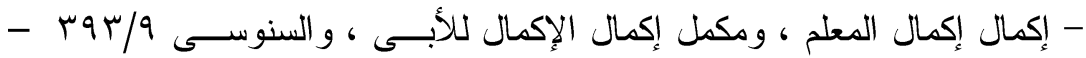

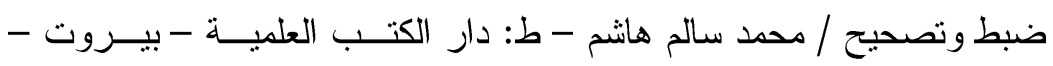

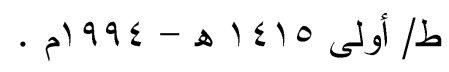




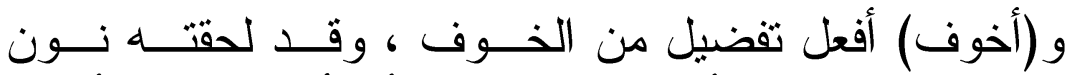

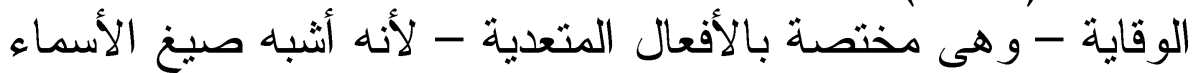

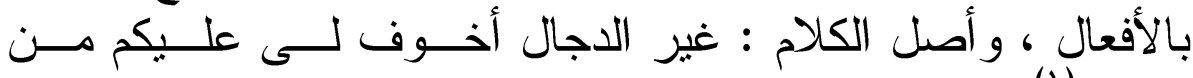

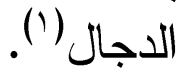

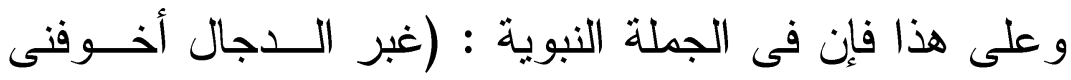

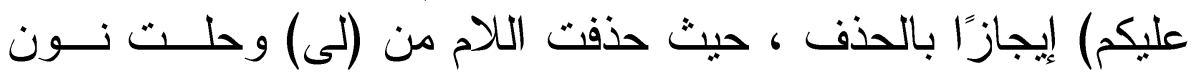

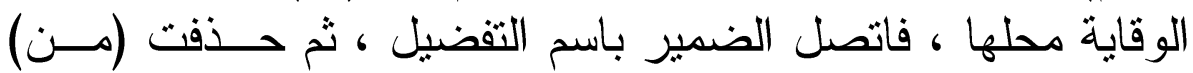

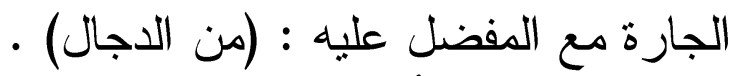

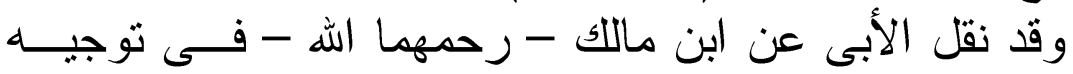

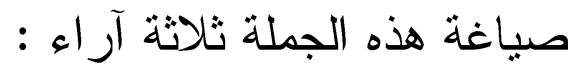

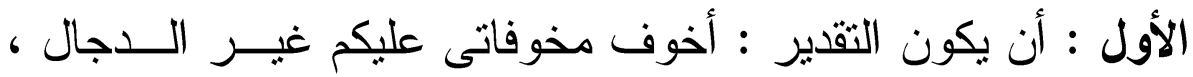

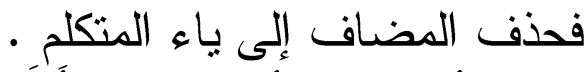

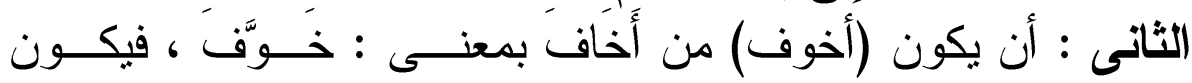
المعنى : غير الدجال أثد موجبات خوفى عليكم .

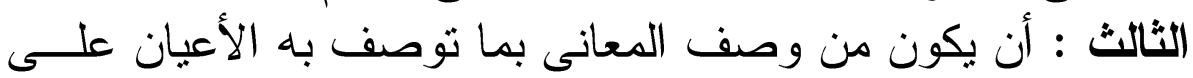

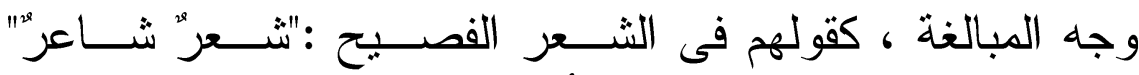

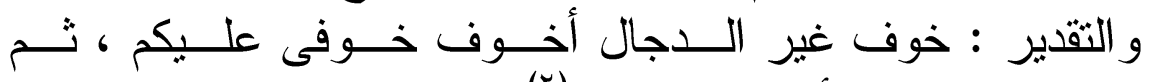
حذف المضاف الأول ، ثم الثانى (r).

وعلى هذا التوجيه الأخير يكون الأسلوب من باب المجــاز

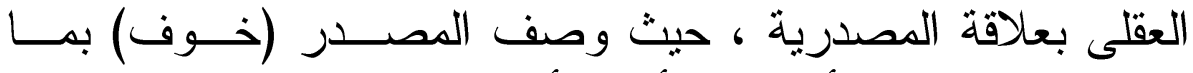

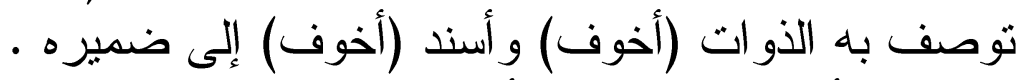

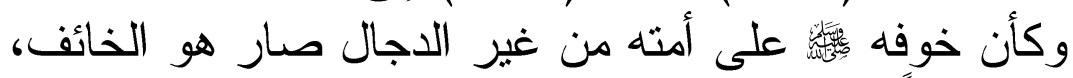

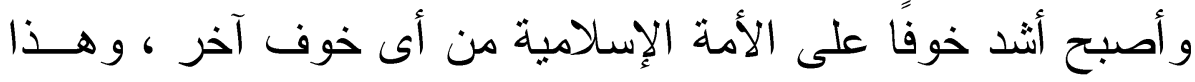

(1) راجع : المفهم rVV/V ، و إكمال إكمال المعلم

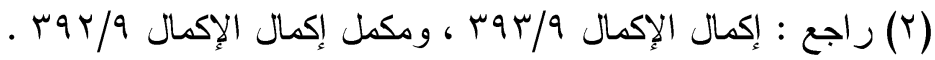




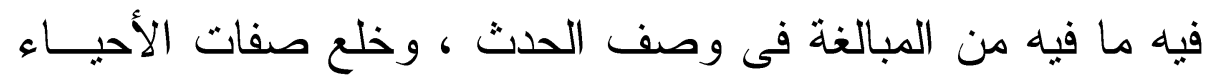

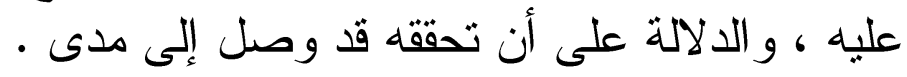

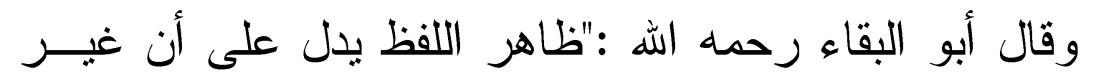

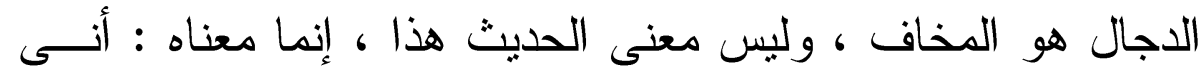

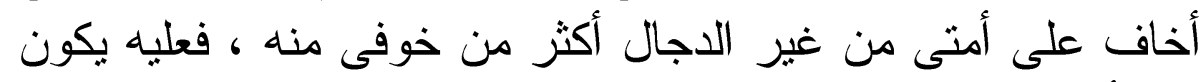

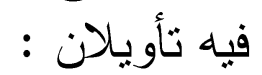

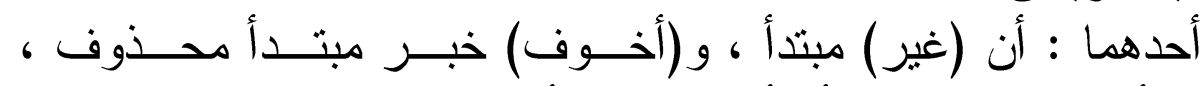

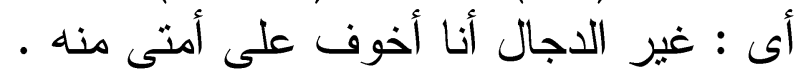

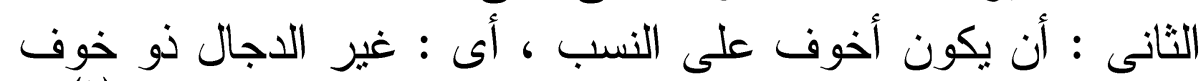

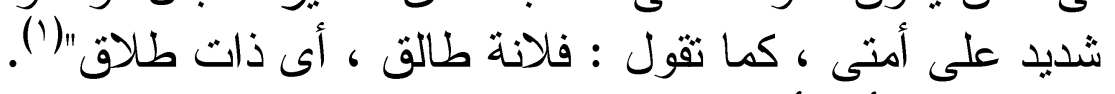

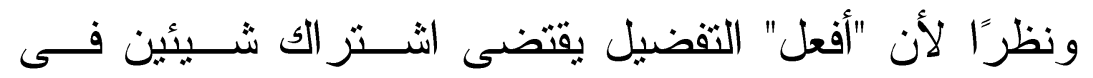

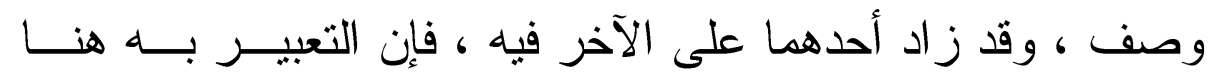

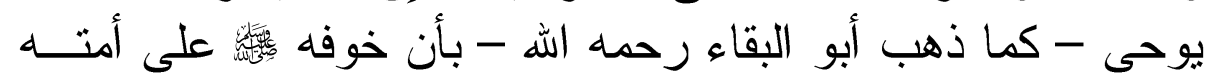

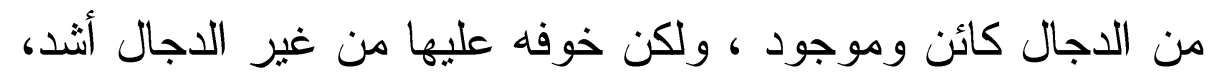

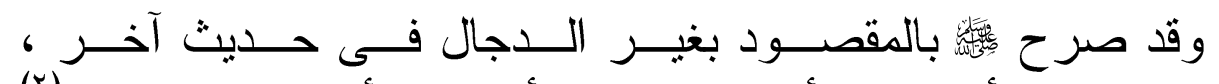

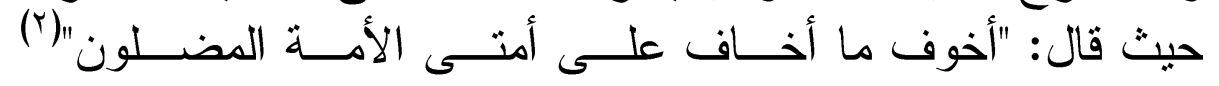

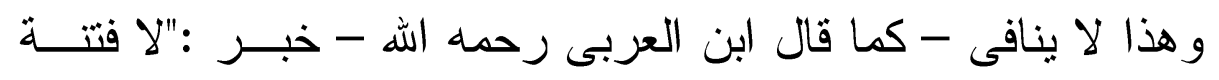

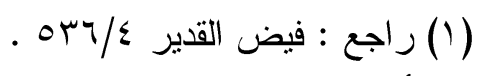

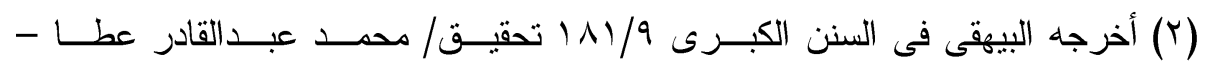

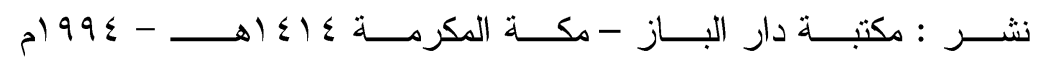

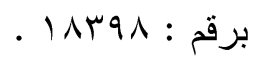

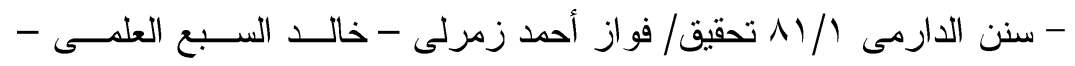

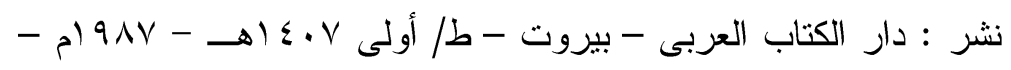

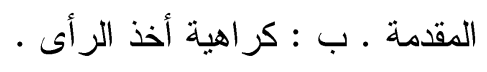




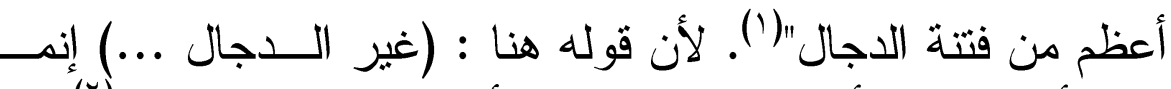

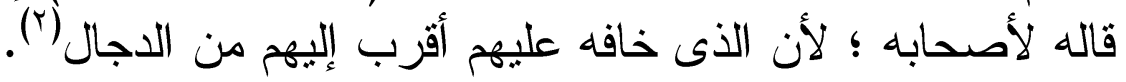

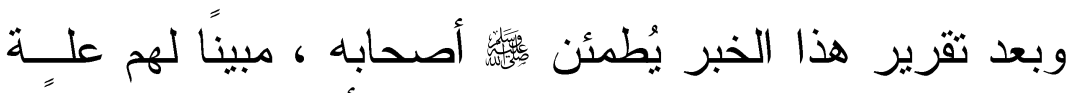

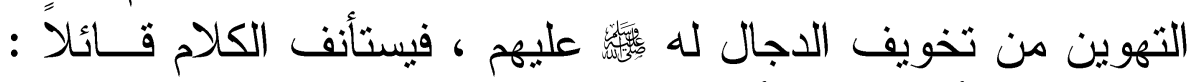

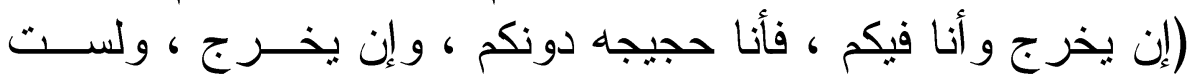

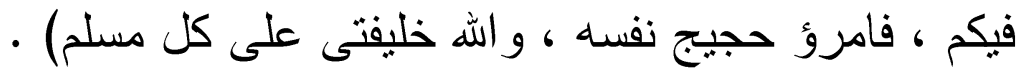

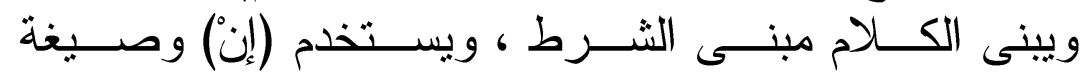

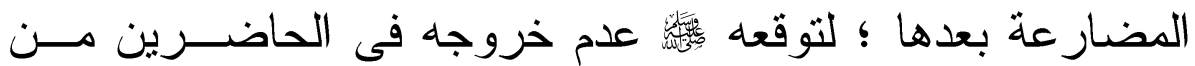

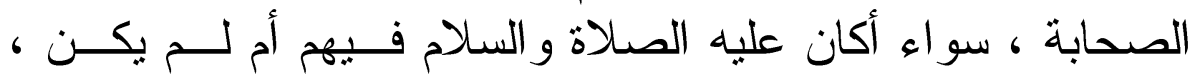

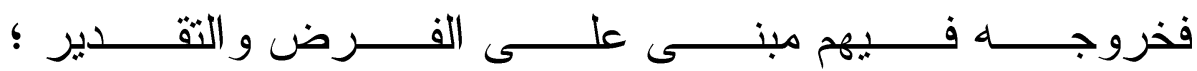
ولذلك استخدم النظم الشريف (إنْ) دون (إذا) لأنها هى التى تستخدم

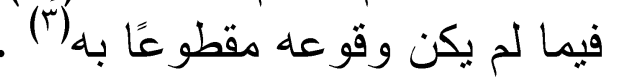

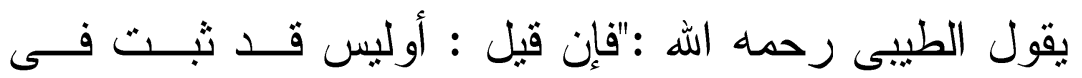

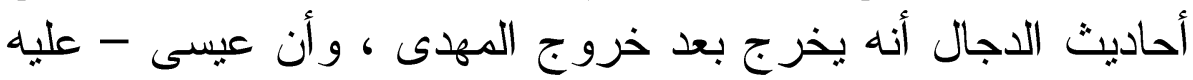

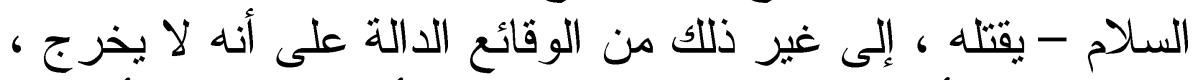

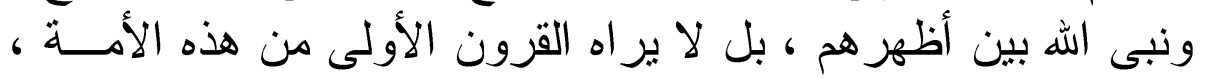

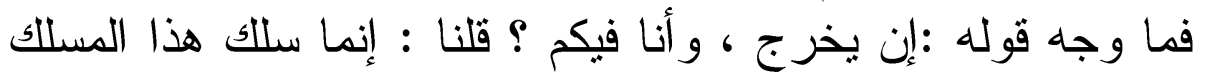

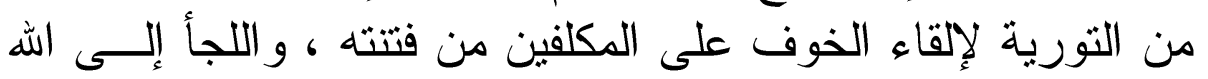

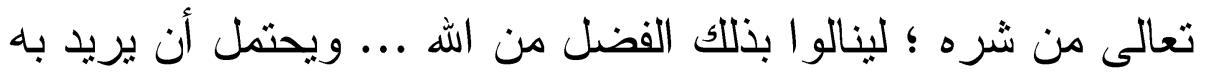

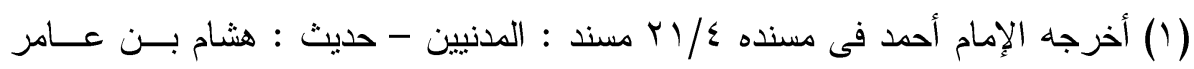

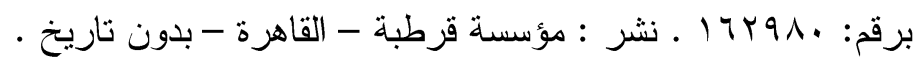

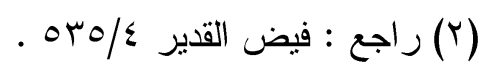

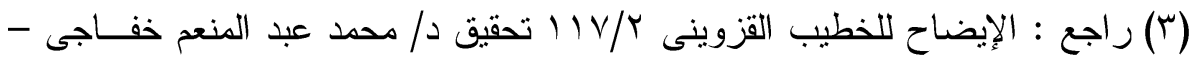

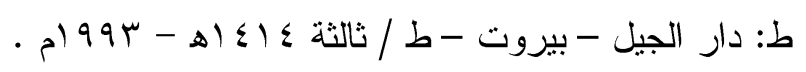




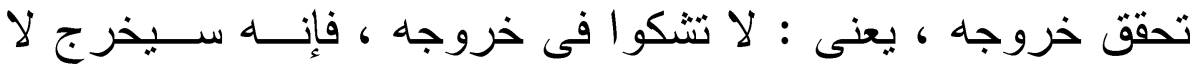

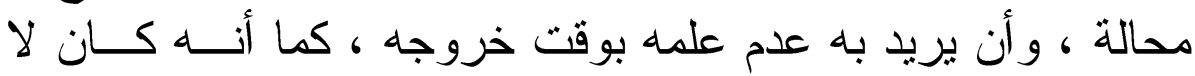

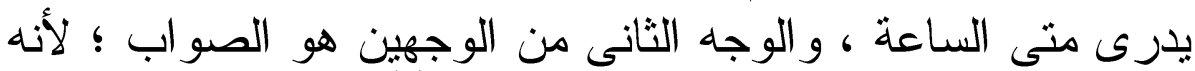

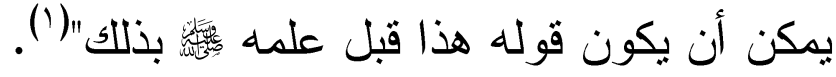

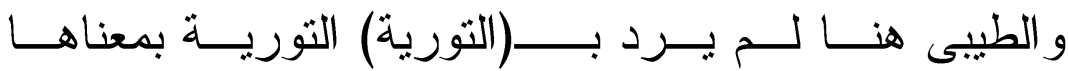

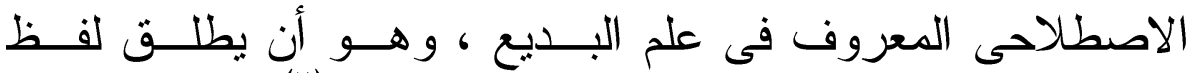

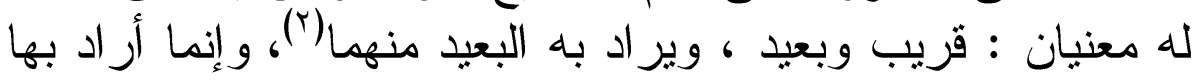

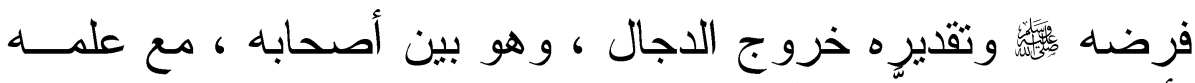

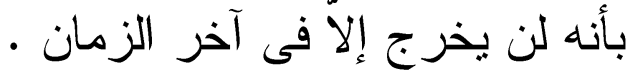

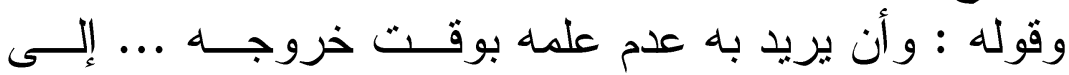

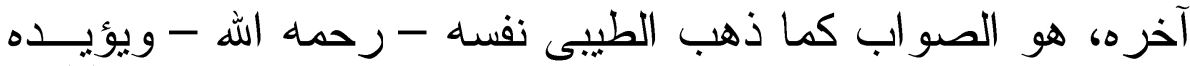

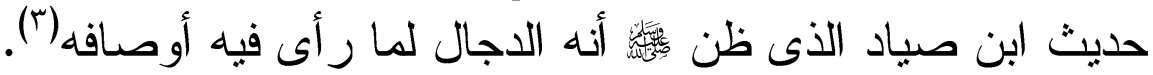

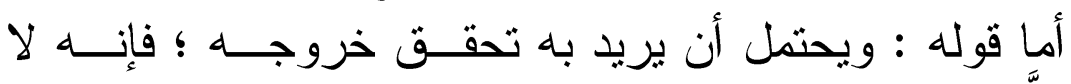
يستقيم إلاً بحمل (إن) فى هذا المقام على معنى (إذا) .

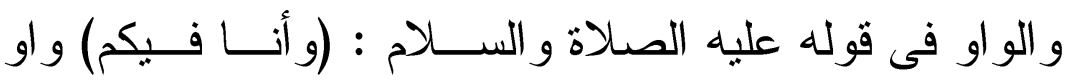
الحال ، و المعنى : إن يخر ج حالة وجودى معكم ، و الفاء فى قوله : (فأنا حجيجه) و اقعة فى جو اب الشرط لربط الشرط بالجو اب. و (حجيج) فعيل بمعنى فاعل ، أى : محاجــه و مخاصــمه ،

(1) راجع : الكاثف عن حقائق السنن للطيبى • 110/1 وما بعدها ـ تعليق / محمد على

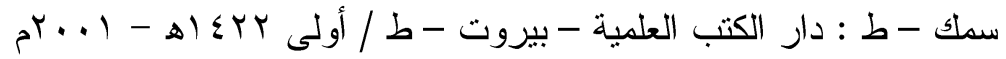

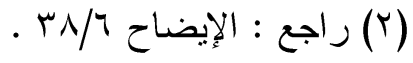

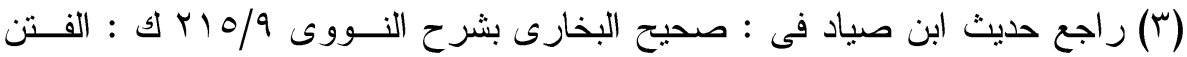

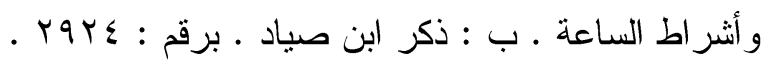


ومقاطعه بالحجة بإظهار كذبه و إفساد قوله (1).

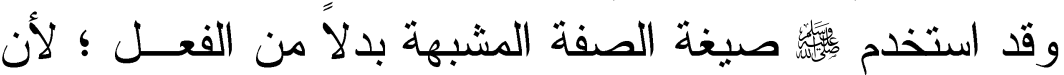

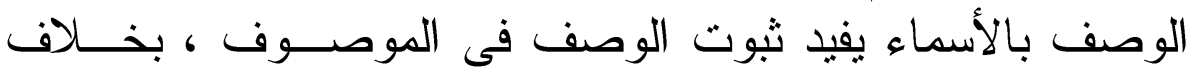

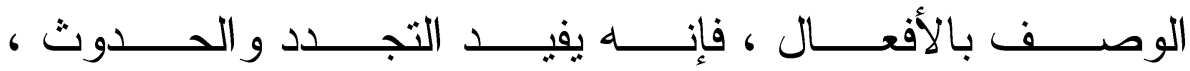

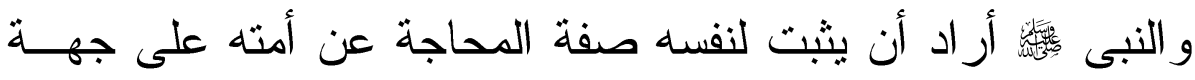

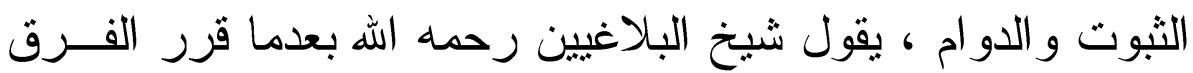

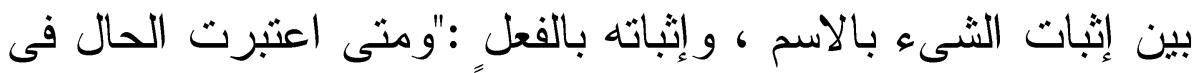

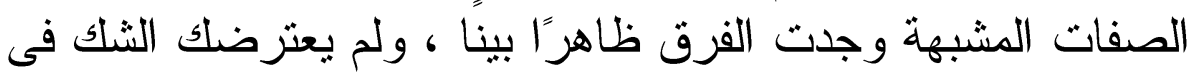

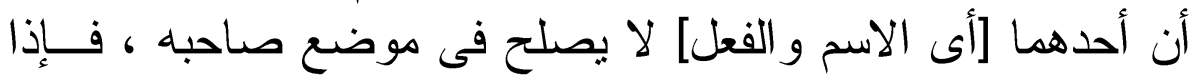

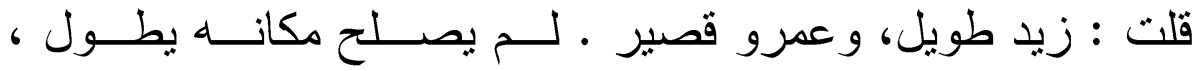

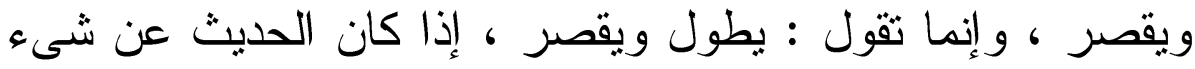

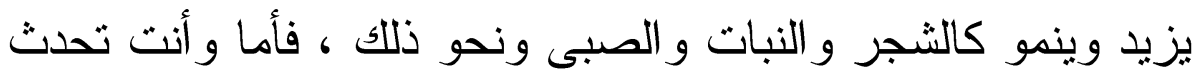

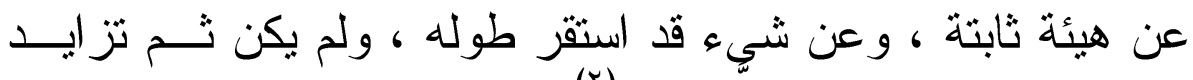

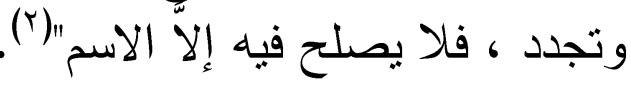

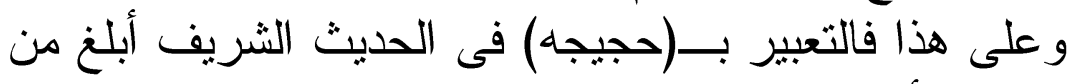

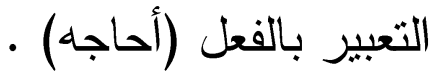

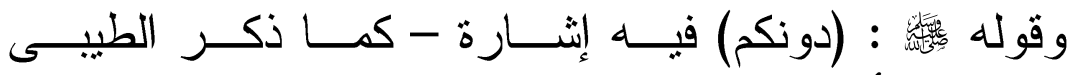

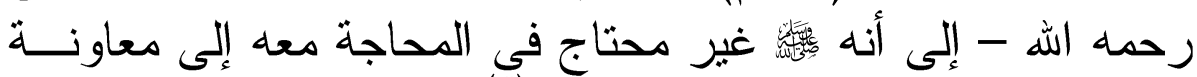

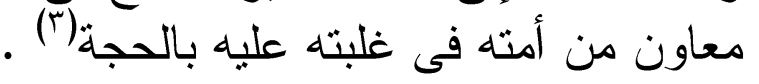

(1) راجع : الدفهم (1)

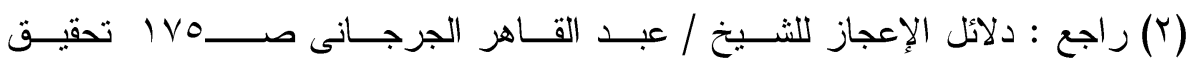

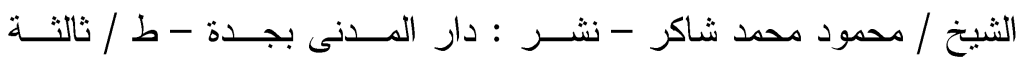

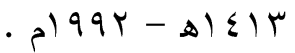

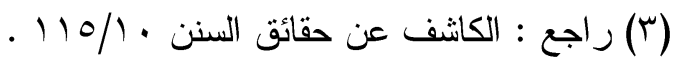


وقد فصل النظم الثريف جملة الثرط : (إن يخرج ، و وأنــا

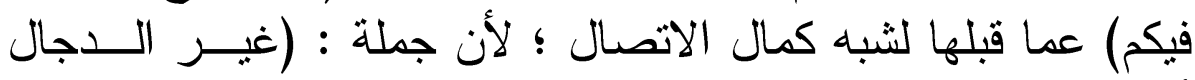

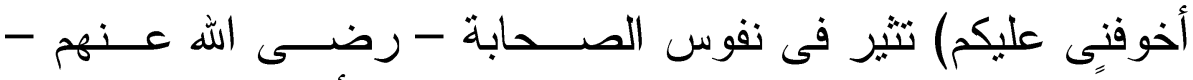

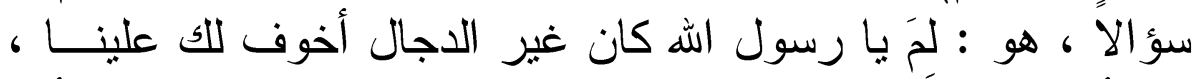

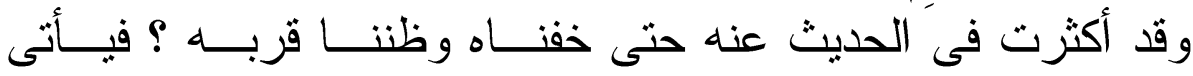

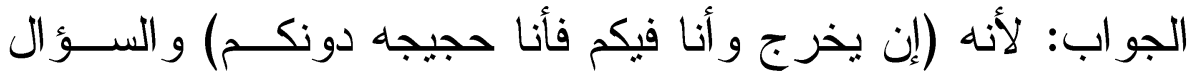

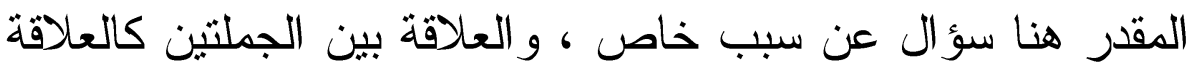

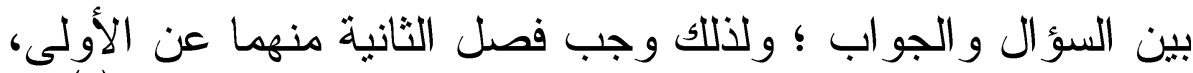

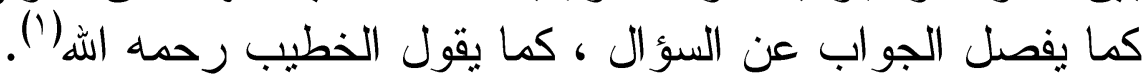

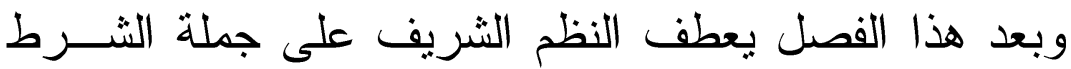

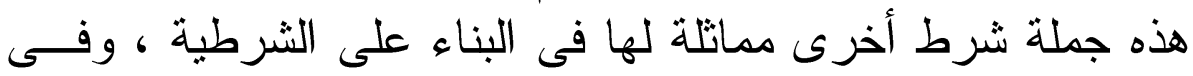

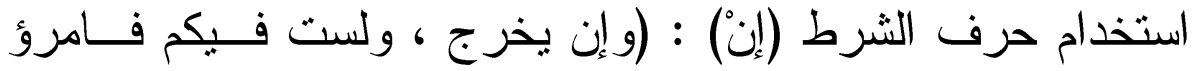

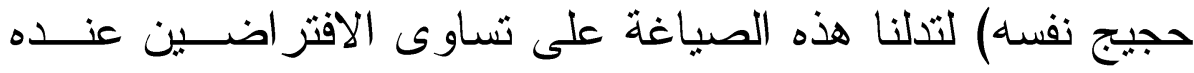

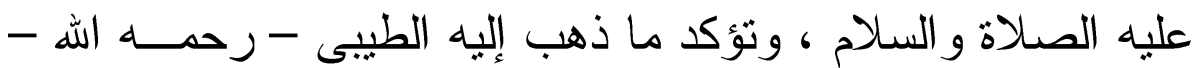

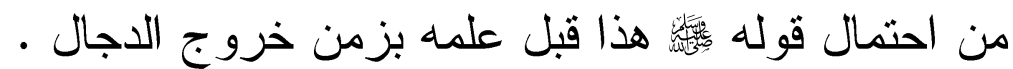

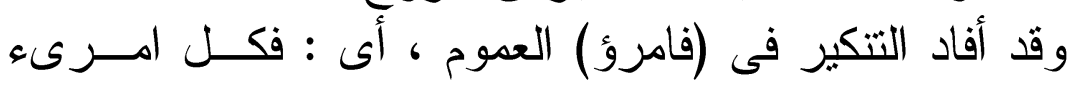

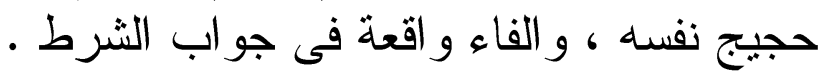

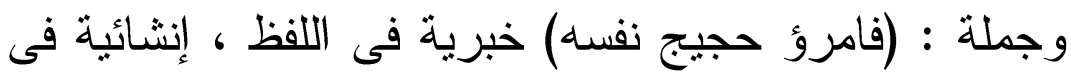

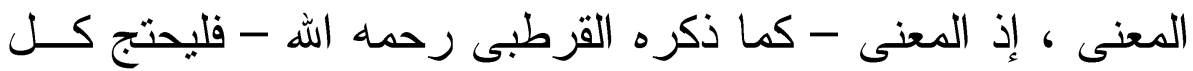

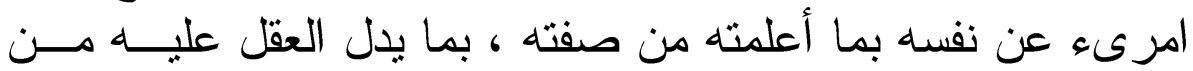

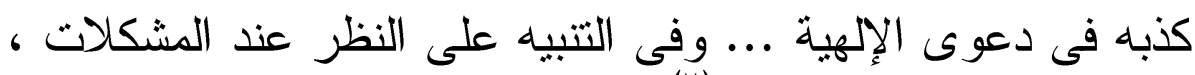
و التمسك بالأدلة الو اضحات الإله (؟).

$$
\begin{aligned}
& \text { (1) راجع : الإيضاح /r/ 119/ }
\end{aligned}
$$

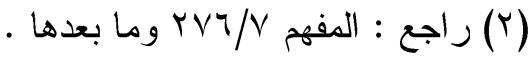


وبين (و أنا فيكم) و (ولسث فيكم) طباق ســلب ، اســتوعب

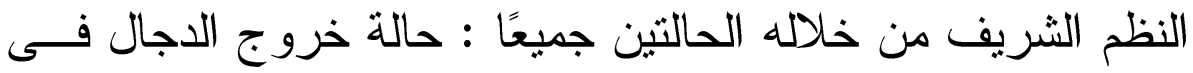

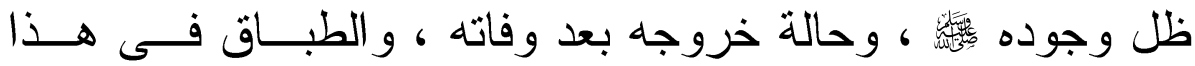

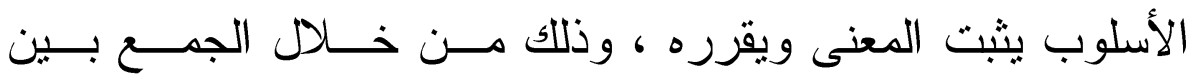
الضدين.

وجملة : (و الله خليفتى على كل مسلم) جملة مســـأنفة فيهــا

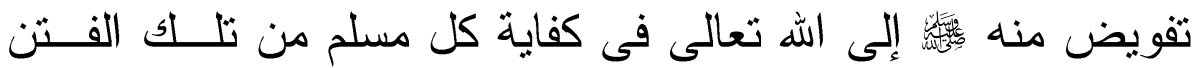

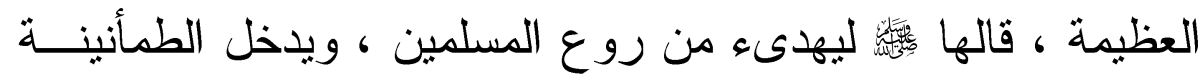
فى قلوبهم

ومن بر اعة النظم فى هذه الجملة الثريفة أن قدم لفظ الجلالة

ليلفت انتباه المسلمين إلى الخبر ، ويشوقهم إليه ، ثم أسند الخبر إلى هـ إهى لفظ الجلالة بطريق الاسمية (خليفتى) لبحيطه بشىء مـــن الثبــات و الدو ام ، ثم أتى بلفظ الإحاطة و الشمول (كل) ليزيد من طمأنينة كل

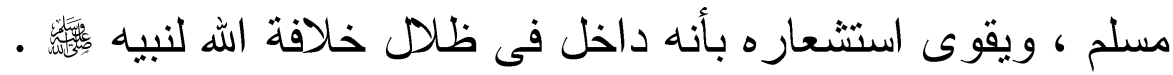

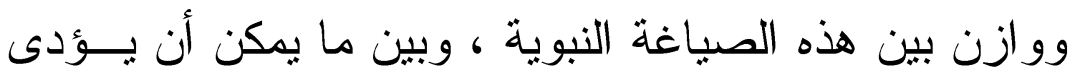

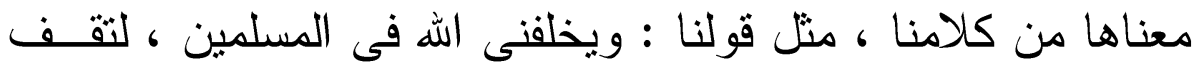

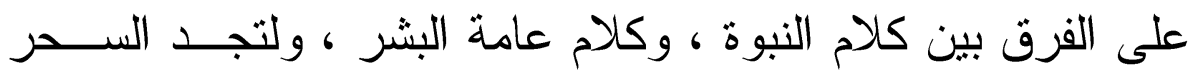
و البراعة التى وجدتها فى الجملة النبوية قد زالت و اختفت ، وكأنها

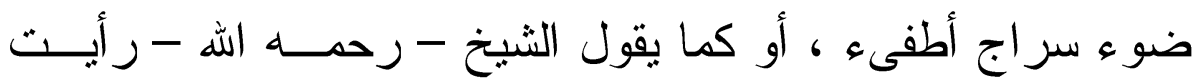

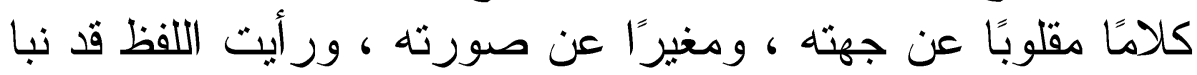

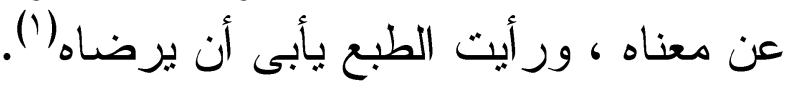




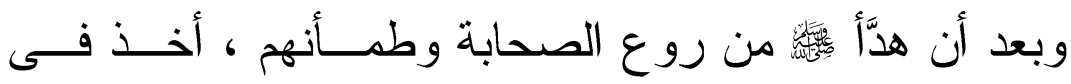

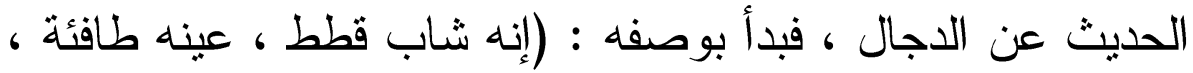

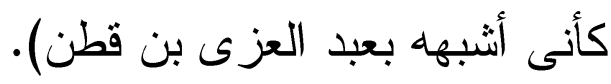

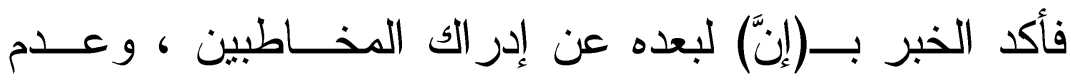

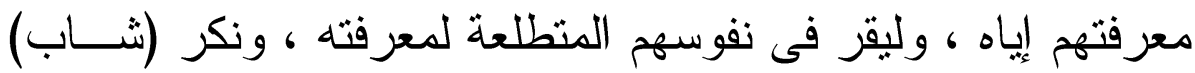
لتفخيم هذا الوصف الذى سيكون عليه الدجال عند خروجهاه .

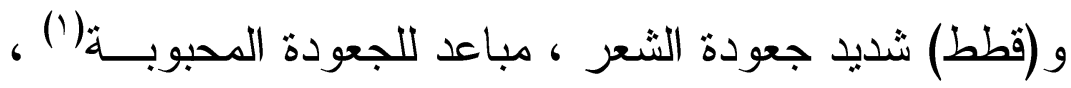

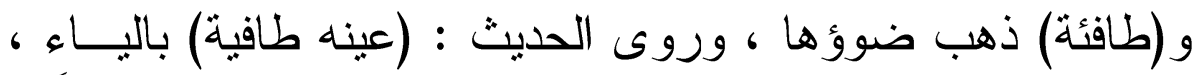

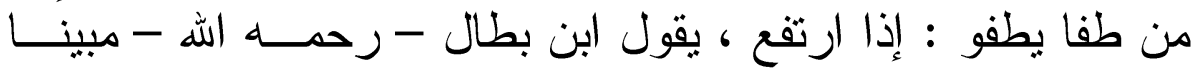

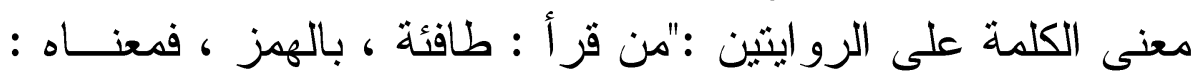

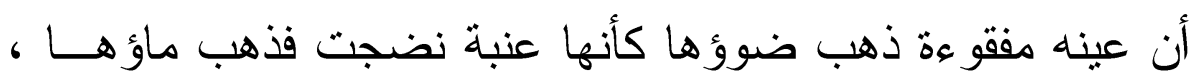

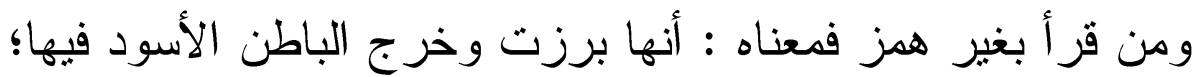

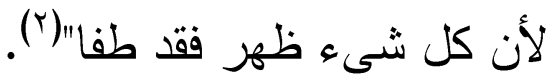

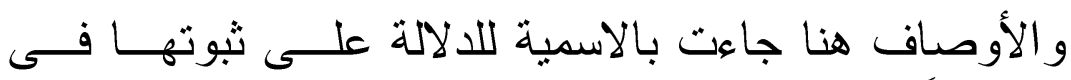

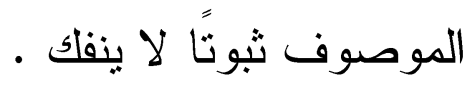
و (كأن) فى قوله فئس

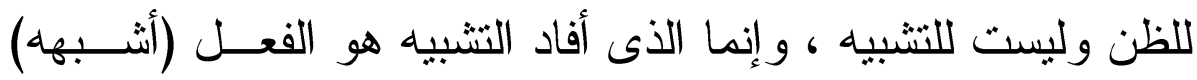

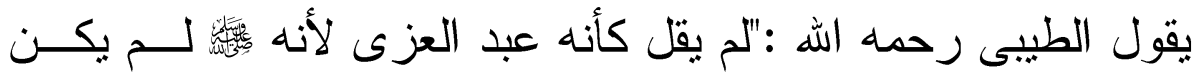

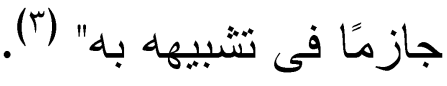

(1) راجع : النهاية فى غريب الحديث الأثر (قطط) .

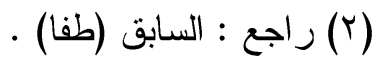

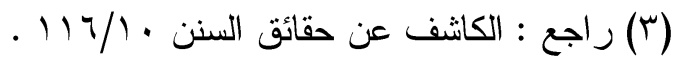




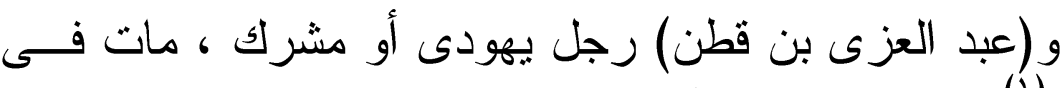

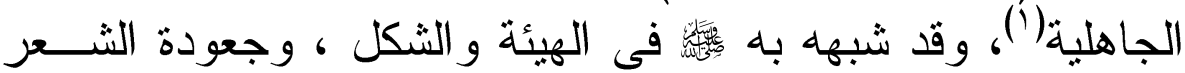

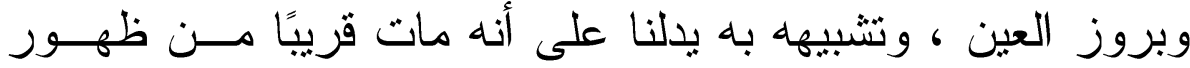

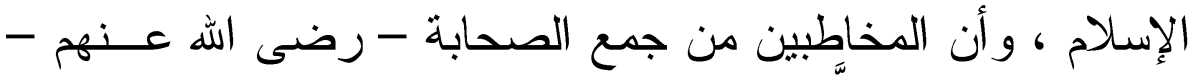

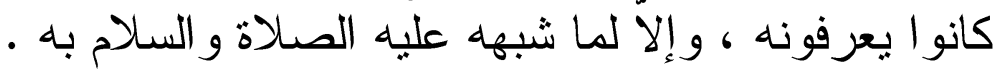

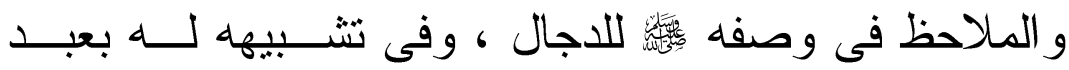
العزى بن قطن ، أنه انحصر فى الأوصاف الحسية المرئية ؛ وذلك لأن الغرض من الوصف و التشبيه هنا هو إظهار الأوصاف التهى فنى

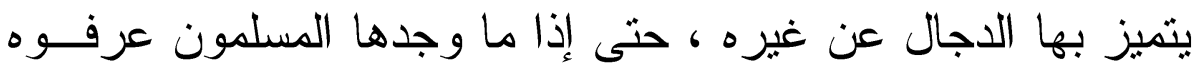

وبعد هذا الوصف و التشبيه ينبه هـ

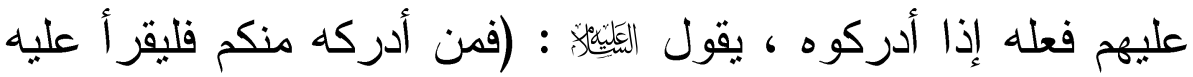

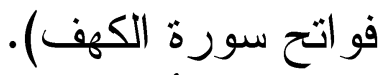
ويبدأ هذه الجملة بفاء الفصيحة التى ســدث مســد شــرط

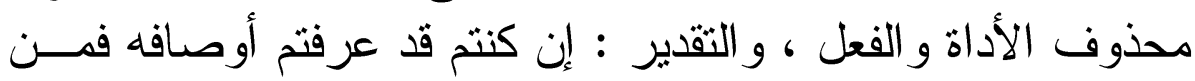

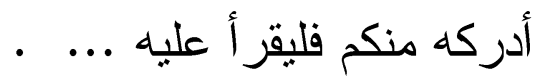
وقد أحدث الحذف هنا إيجازًا فى اللفظ ، و وتقليلاً فى العبارة، و إثارة للخيال نحو البحث عن الجزء المفقود من الجملة . و امثادًا لإثارة الخيال وتتبيه المخاطبين وثشويقهم نحو الخبر

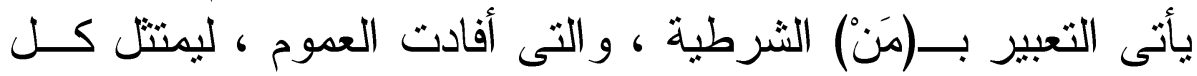

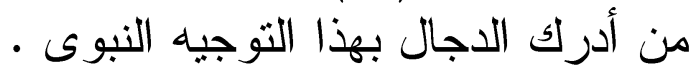

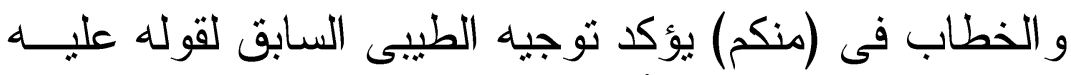
الصلاة و السالام : (إن يخر ج و أنا فيكم ....) . 
ومن المكن حمل الخطاب هنا على العموم ؛ ليدخل فى هذا

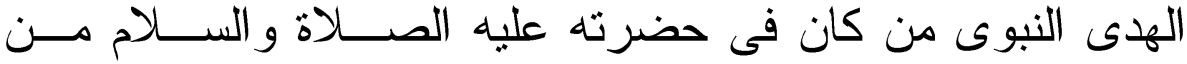

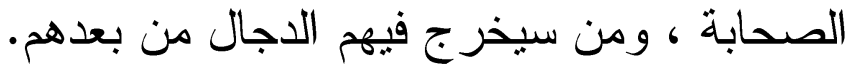

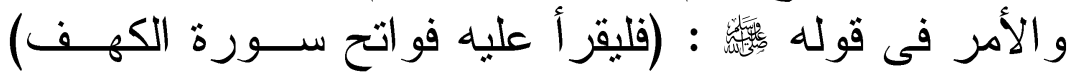

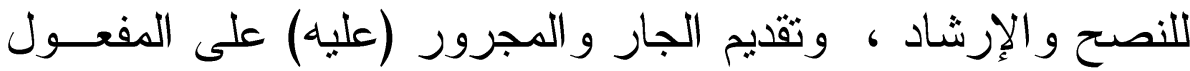

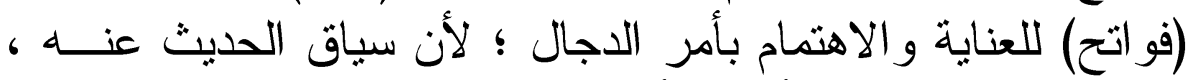

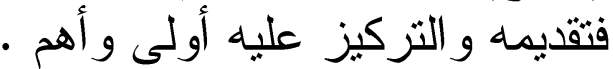

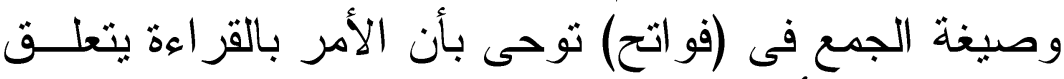

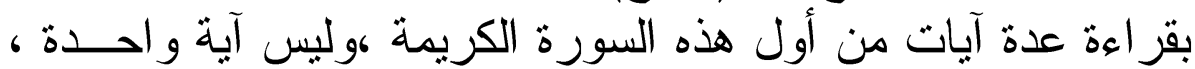

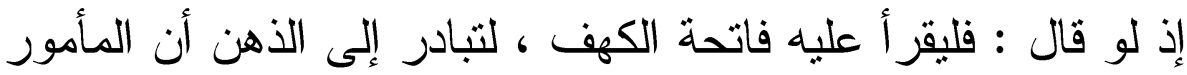

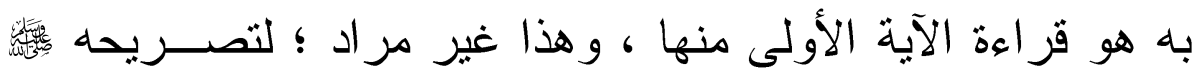
فى رواية أخرى بالعشر آيات (1).

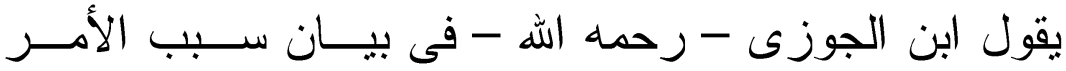

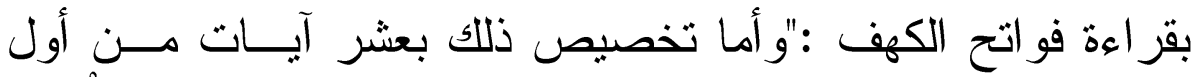

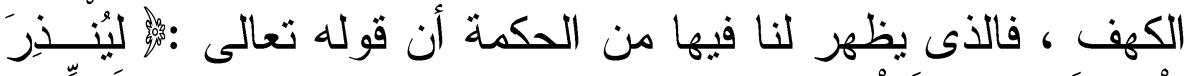

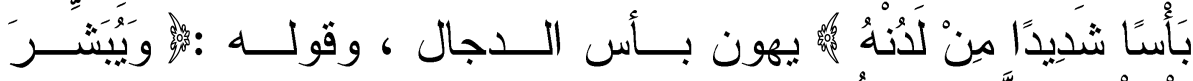

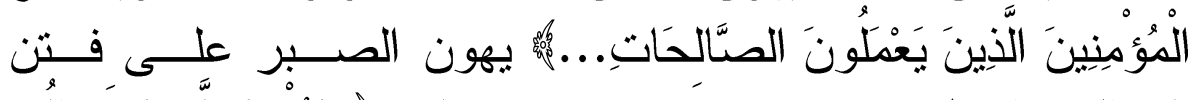

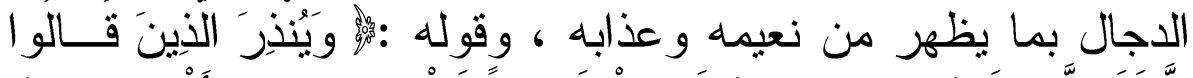

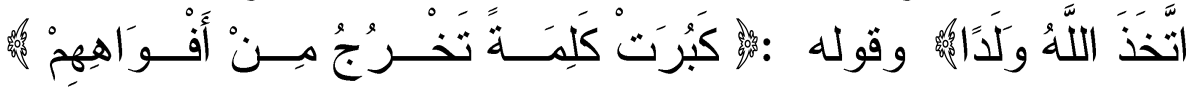
فذم من يدعى له ولدًا و لا مثل له ، فكيف يدعى الإلهية من هو مثل

(1) راجع الحديث فى : مسند الإمام أحمد 197/0 مسند الأنصار -بــرقم : . . IVY.

$$
\text { حديث أبى الدرداء . }
$$

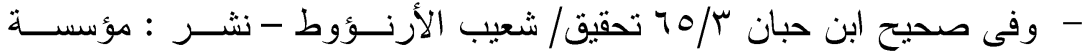

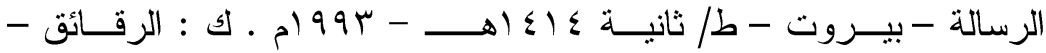


للخلق ... فقد تضمنت الآيات ما يصرف فتنة الدجال إلى قولـــه :

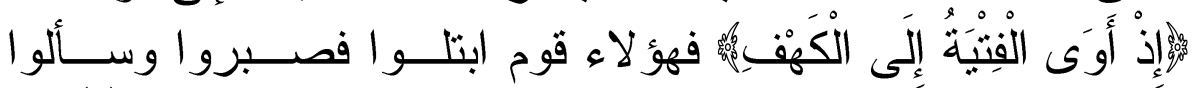

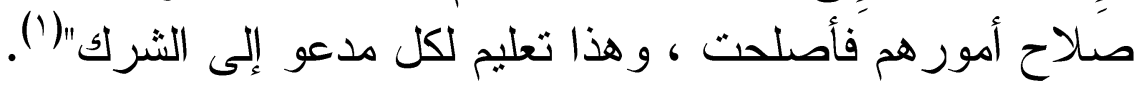

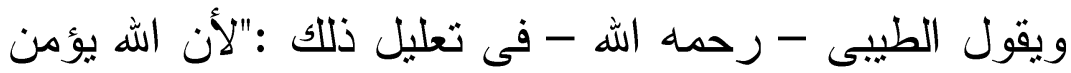

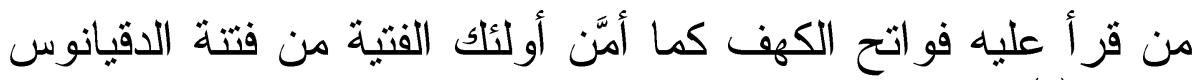

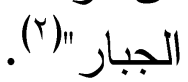

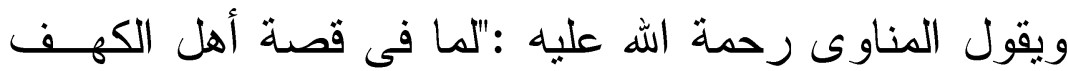

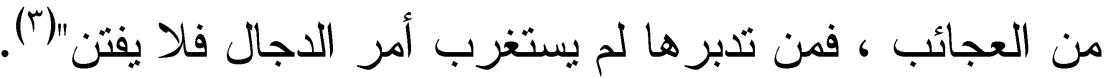

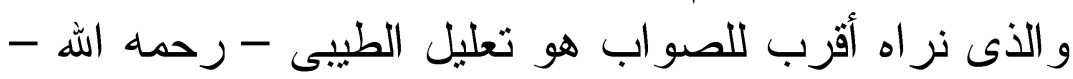

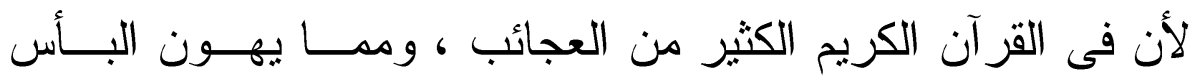

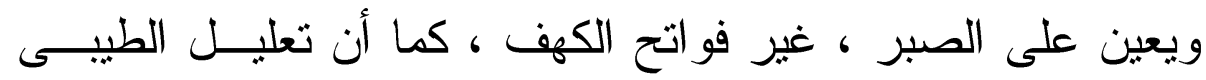

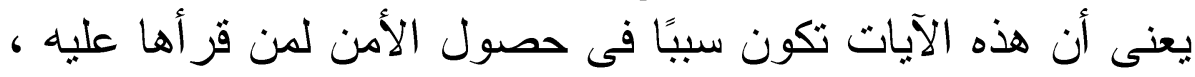

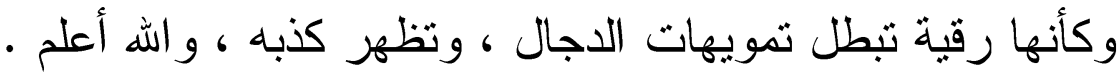

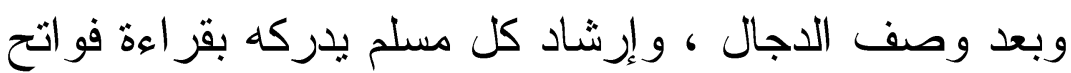

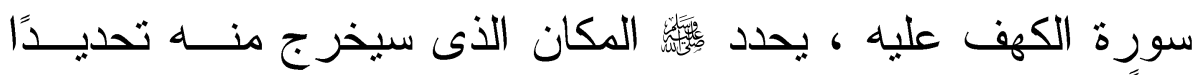

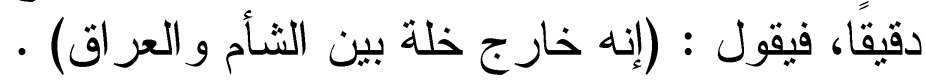

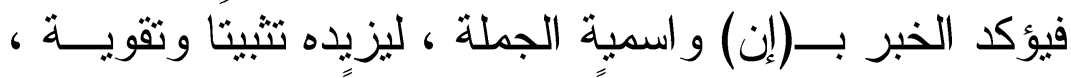

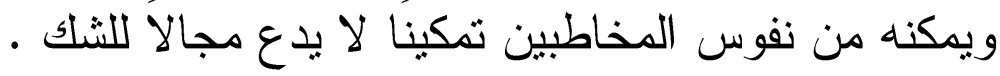

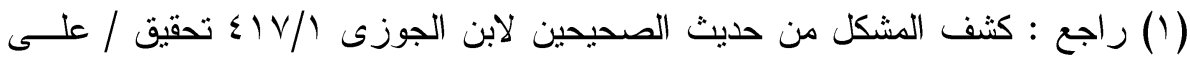

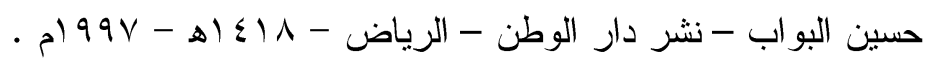

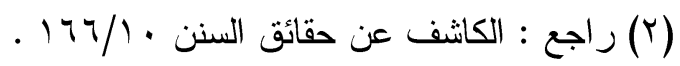

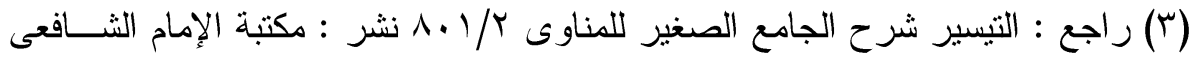

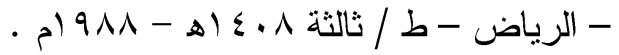


و التوكيد هنا كالتوكيد السابق : (إنه شاب قطط) وكلاهما لم

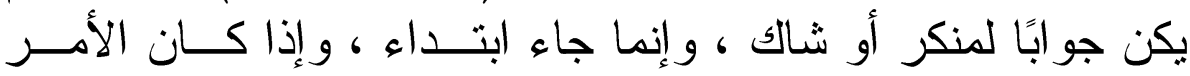

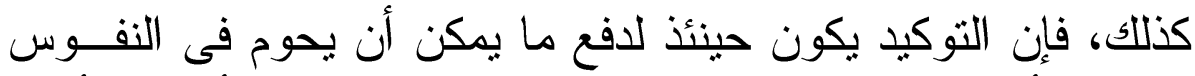

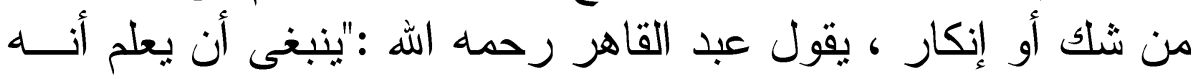

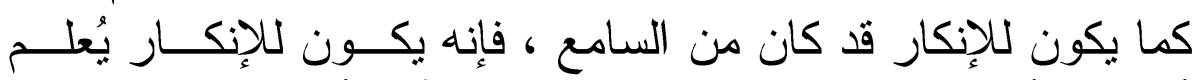

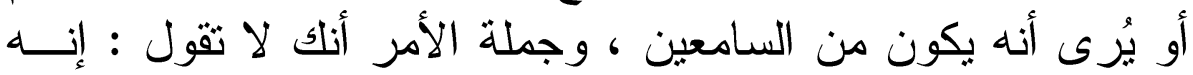

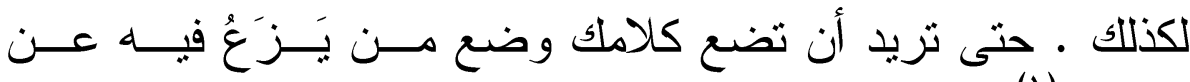

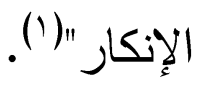

ويقول د / عز الدين على السيد رحمه الله :"والكلام قد يؤكد

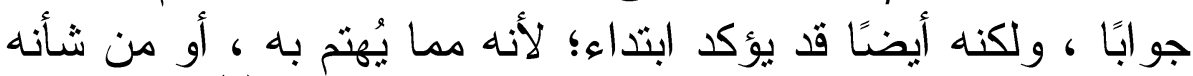

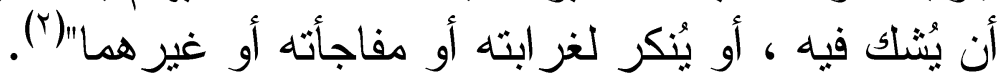

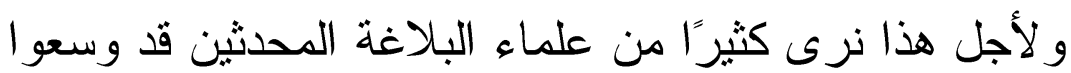

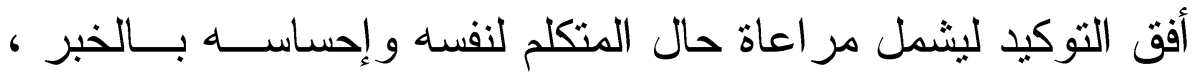

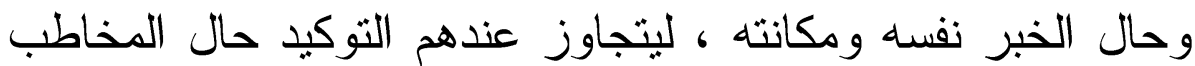
التى حبسه فيها قدامى البلاغيين رحمهم الله" (ب).

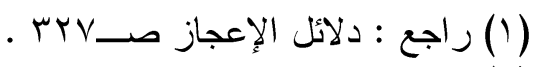

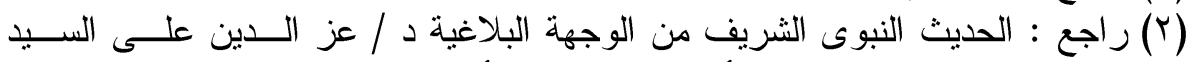

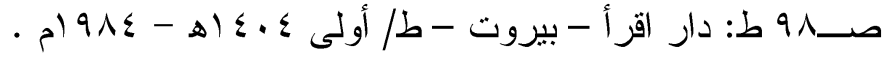

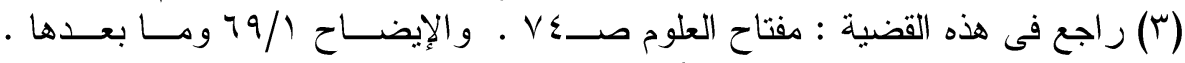

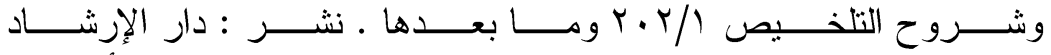

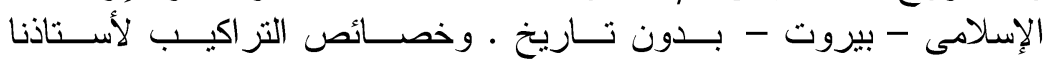

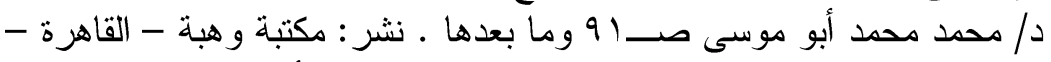

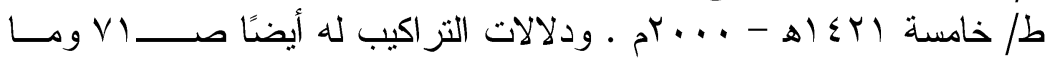

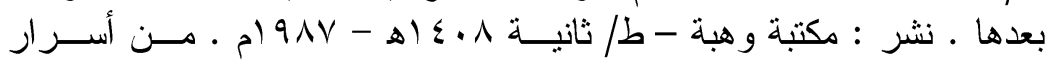

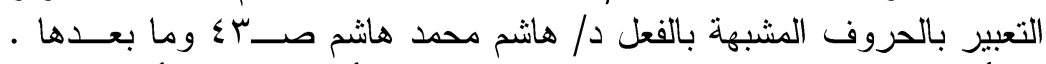

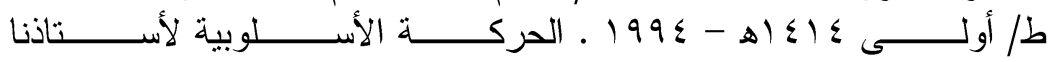

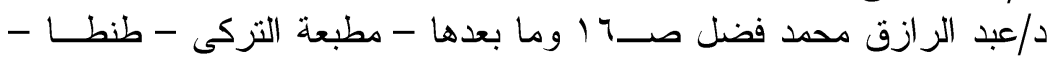


و (خَلَّة) في الحديث الشريف بالخاء المعجمة وتشديد الــلام

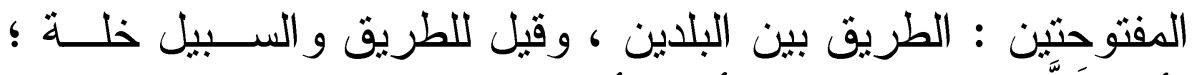

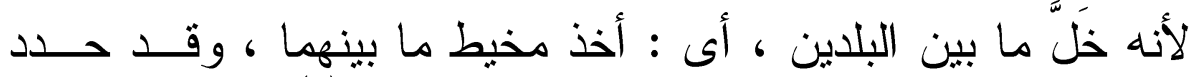

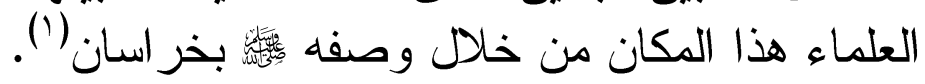

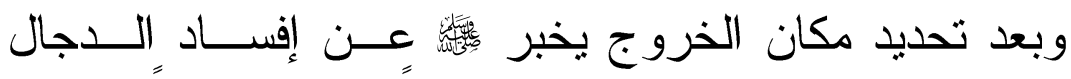

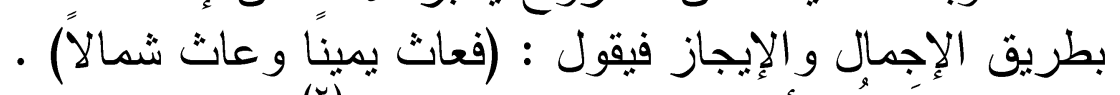

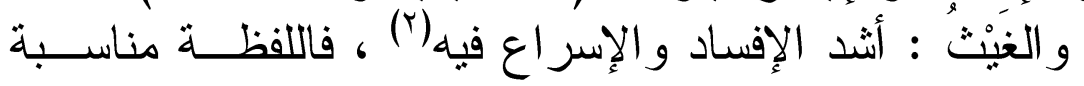

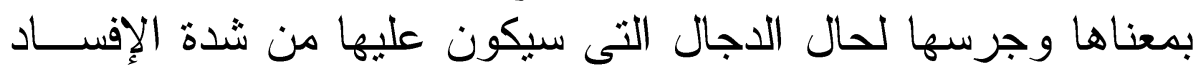

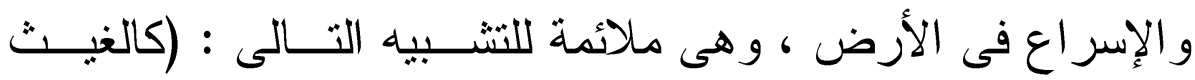

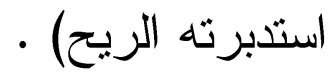

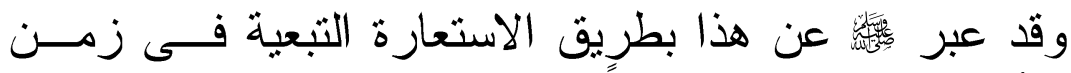

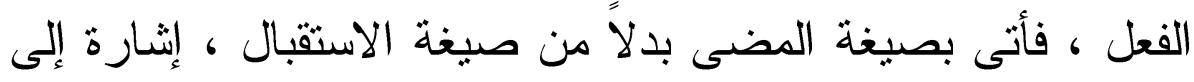

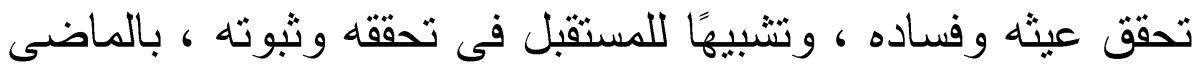

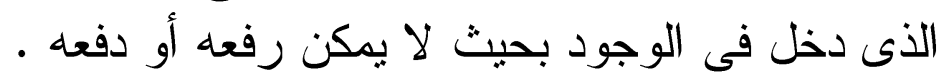

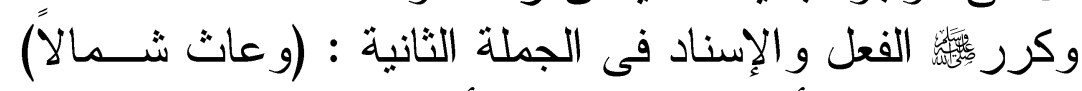
للنص على الفعل مرة أخرى زيادة فى الأناكيد و التحقيق .

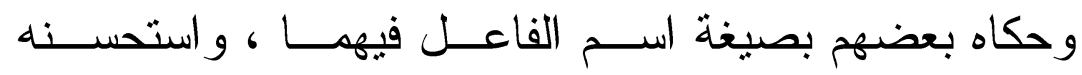

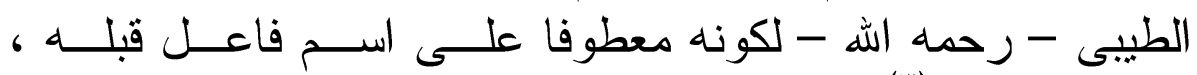
وهو : (خارج) (r).

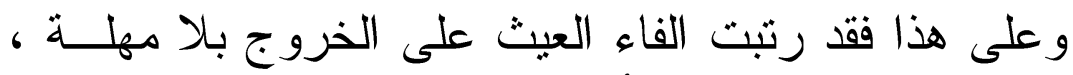
ودلت على سرعة الإفساد فى الأرض بعد ألى الخروج على الخروج

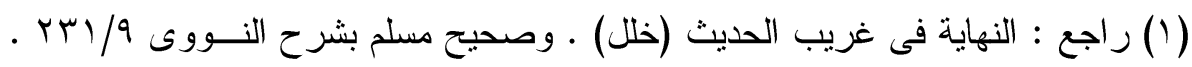

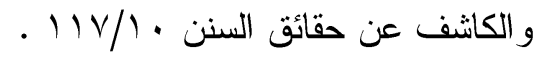

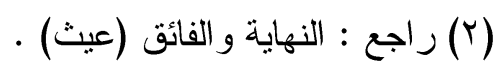

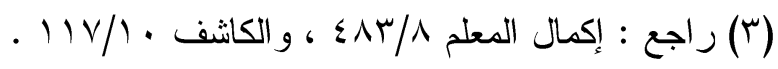


و عبر النظم الثريف بالظرف : (يمينًا وشمالاً) إثـارة إلـى

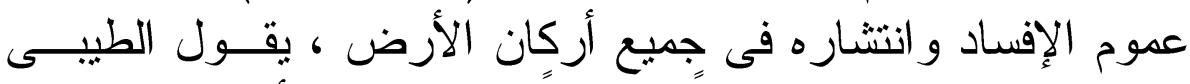

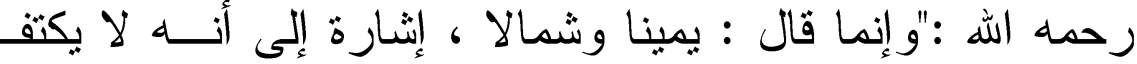

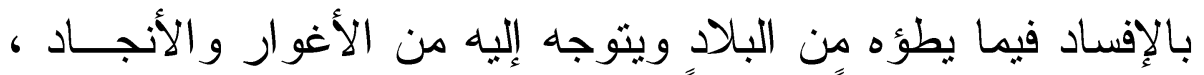

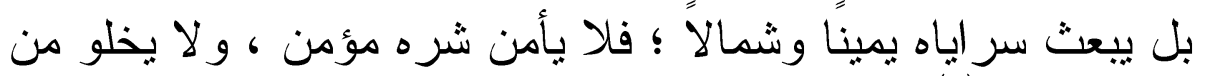

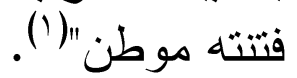

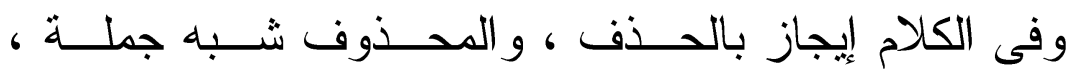

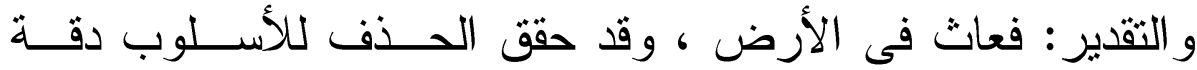

و العطف فى (وعاث شمالاً) للتوسط بين الكمــالين ، حيـــث و وإحكاهًا .

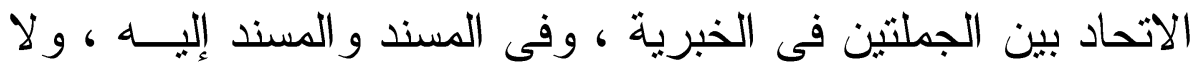
يوجد ثم مانع من العطف "و لا شك أن هذه الصـلات المحكمة بــين

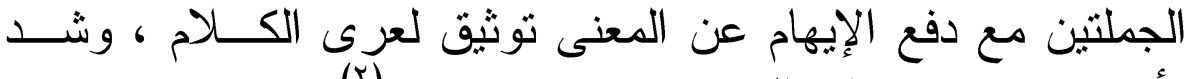

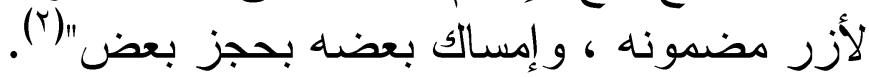

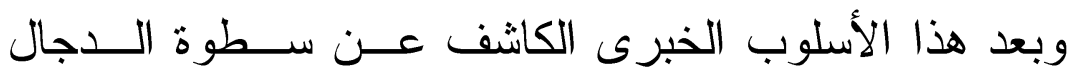

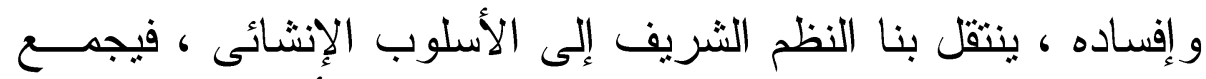

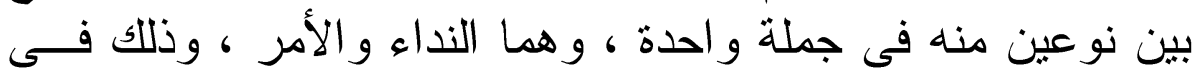

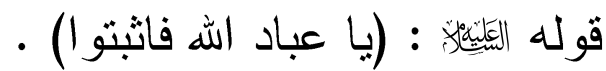
حيث بدأث هذه الجملة الشريفة بالنداء اللافت المنبه للقلوب

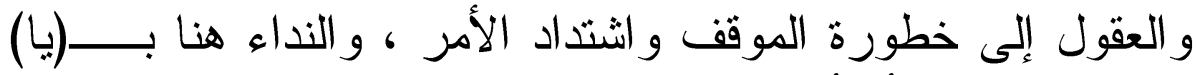
وليس بالهمزة ، أو أى ؛ وذلك لما فى (با) من زيادة اللفت و التنبيه المصاحب لمد الصوث بهذا الحرف ، وما فيه أيضًا من الإشــارة إلى أن ما سيأتى بعده من الأمور المههة التـى بجـــبـ اســتيعابها 
و الاهتمام بها ، أو كما يقول الزمخشرى رحمه اله :"للتأكيد المؤذن

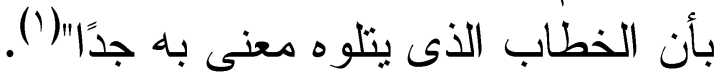

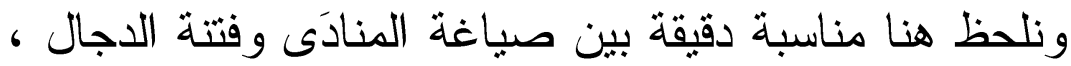

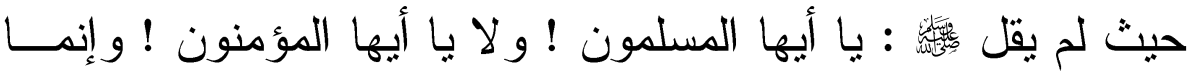

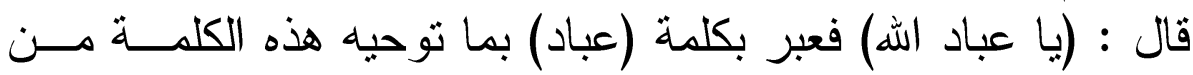

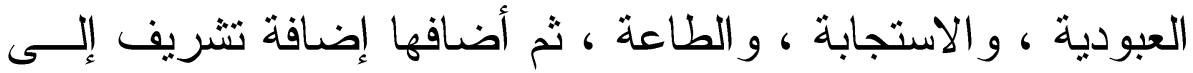

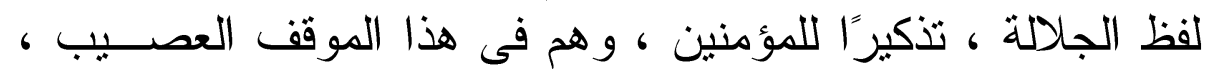

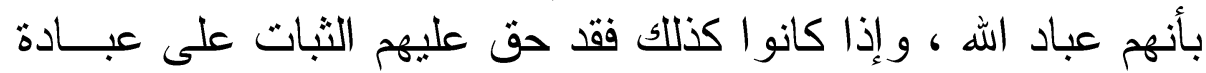

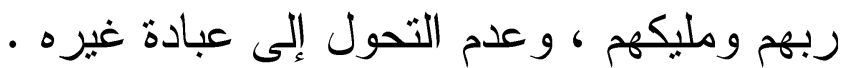

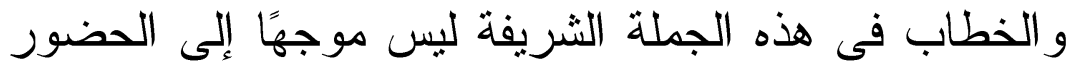

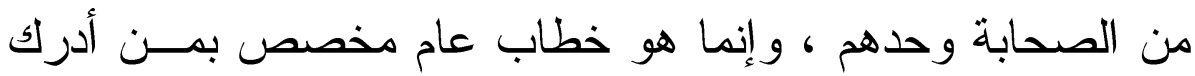

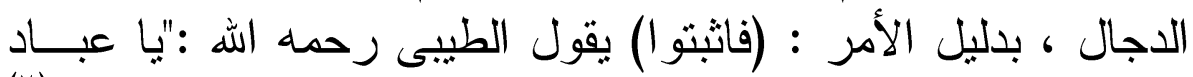

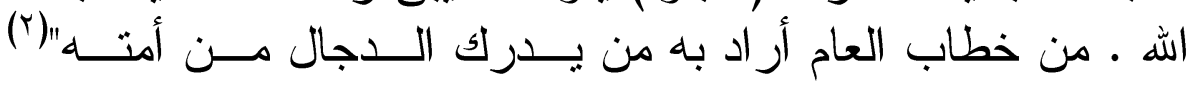

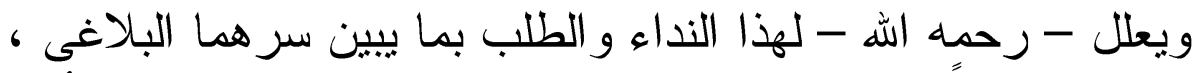

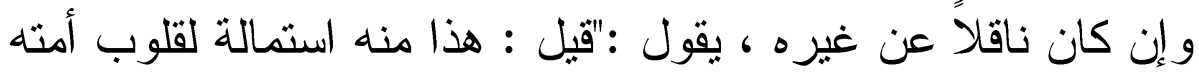

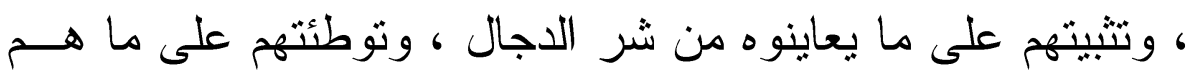

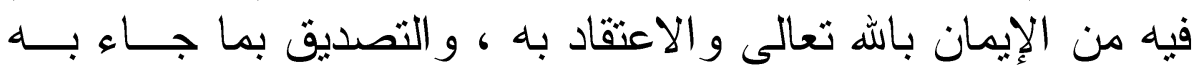

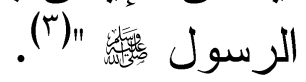

و على هذا تكون صيغة الأمر (اثتبوا) قد خرجت عن معناها

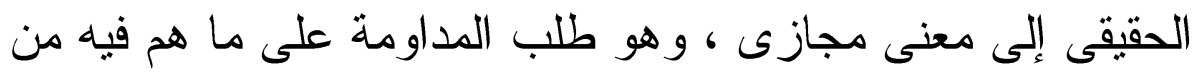

( (1) راجع : الكشاف للزمخشرى 10/1 شرح وضبط / يوسف الحمادى - نشر : مكتبـة

$$
\begin{aligned}
& \text { مصر - الفجالة - بدون تاريخ . }
\end{aligned}
$$

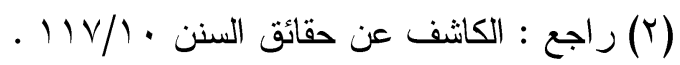

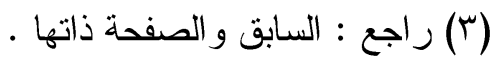


ثبات على عبادة الله وحده ، فيكون المعنى : يا عباد الله ! داومـــوا

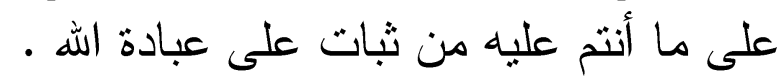

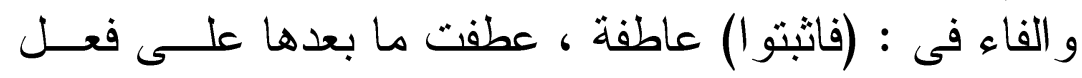

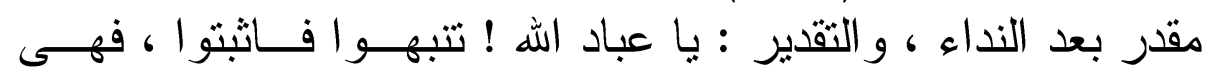

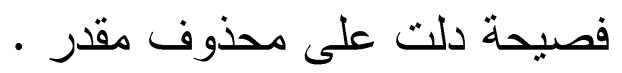

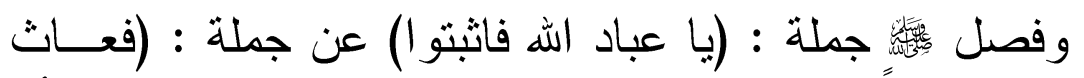

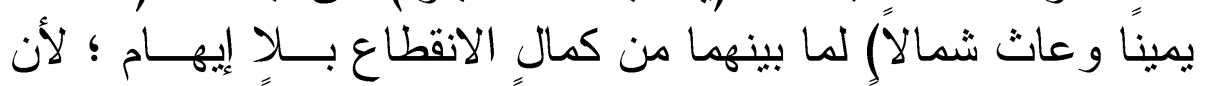

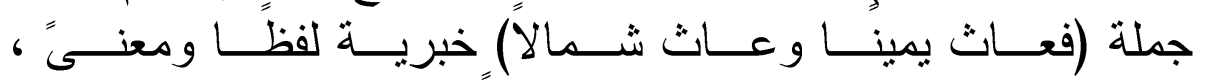

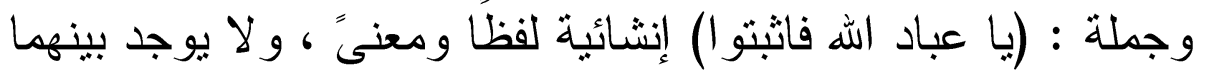

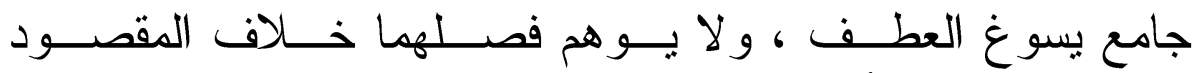

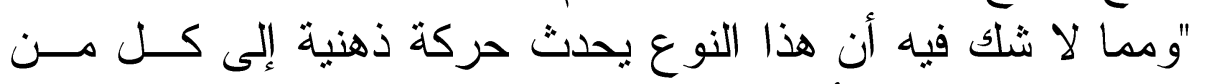

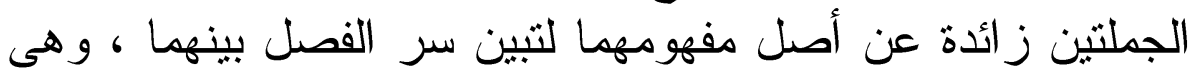

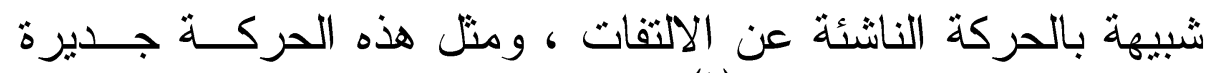
بتقريز المعنى و التتبيه إليه" ('). وبعد هذا التوجيه النبوى يعود الحديث الشريف إليه التى أسلوب

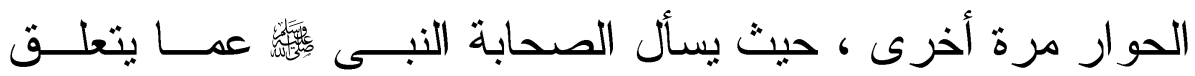

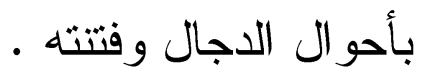

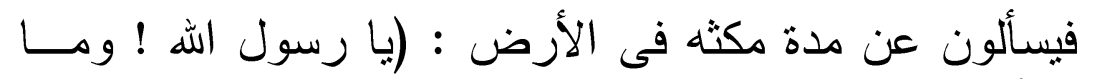

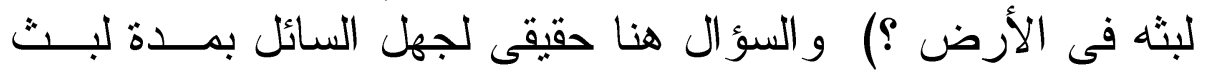

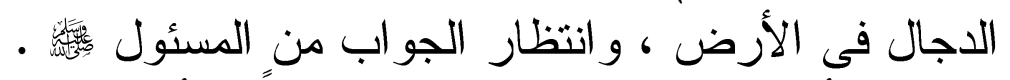

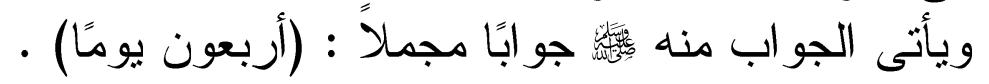

( (1) راجع : إخراج الكلام على خلاف مقتضى الظاهر فى كمالى الانقطاع و الاتصــال .

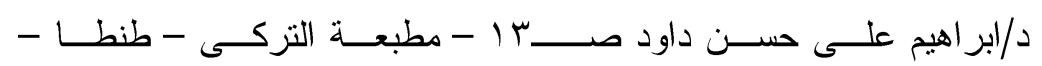

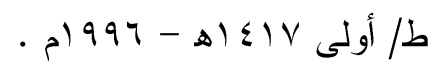


ويبدأ النظم الشريف هذا الجو اب بالحــذف ، حيـــث حـذذف

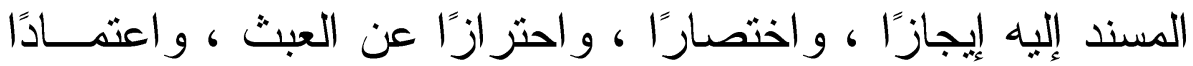

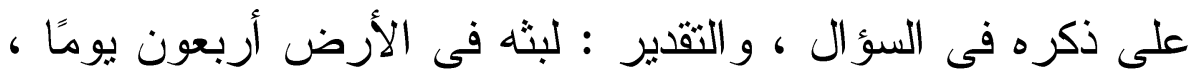

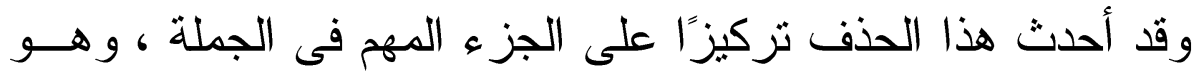
تحديد مدة لبث الدجال فى الأرض ، لأنه الجزء الذى تثعلق به أفئدة

السائلين.

وبعد هذا الجواب المجمل ، يتخذ البيان النبوى البليغ طريق

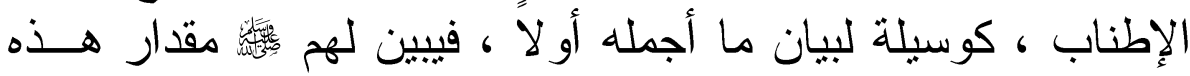

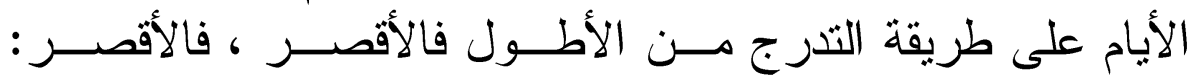
(يوم كسنة ، ويوم كشهر ، ويوم كجمعة ، وسائر أيامه كأيامكم) .

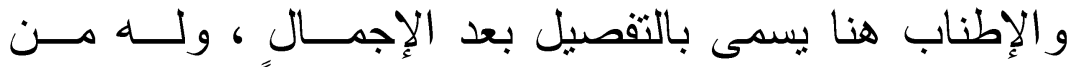

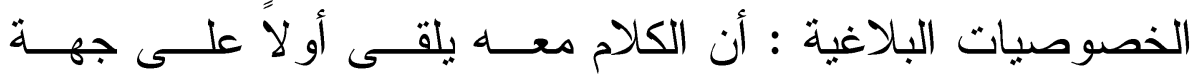
الإجمال ، ثم يفصل ، و المعنى - كما بقول الخطيب رحمــهـ الله -

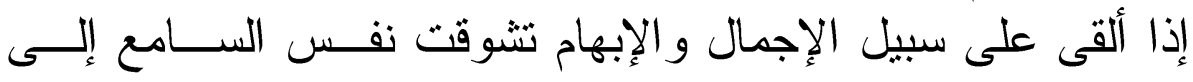

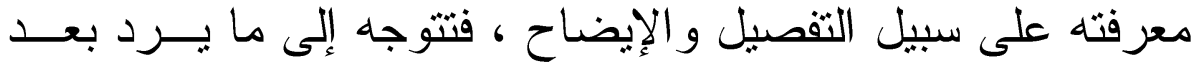

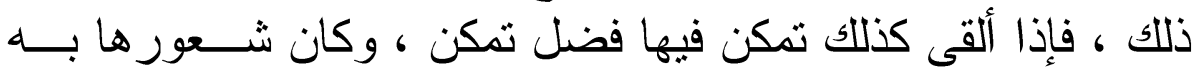

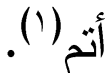

وخلال هذا التفصيل بستخدم النظم الشريف أسلوب التشــبيه

لبيان مقادير هذه الأيام فى الطول ، ويقيسها على الأبام التى بعيشها الناس قبل ظهور الدجال: (يوم كسنة ،ويوم كشهر ، ويوم كجمعة).

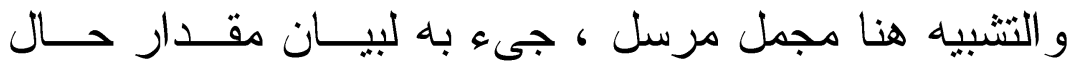

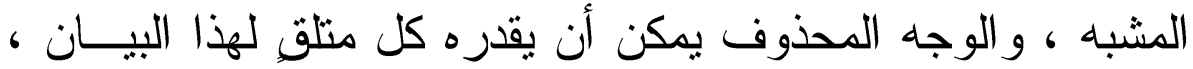
وقد أحدث حذفه للأسلوب نوعًا من الإبجاز و الإثارة . 
وقد اختلف شر اح الحديث حول تفاوت أطو ال هذه الأيام هل

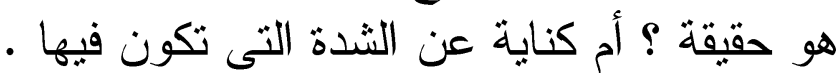

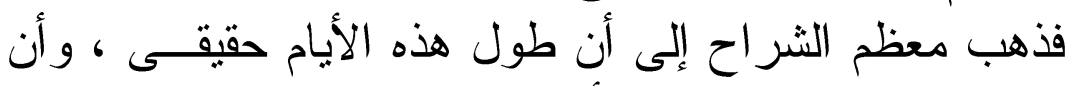

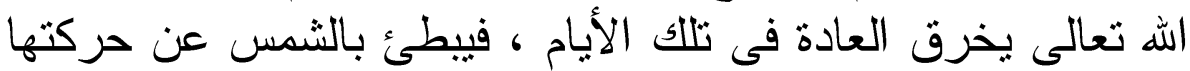

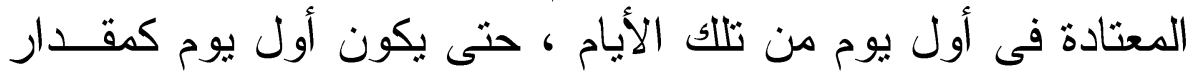

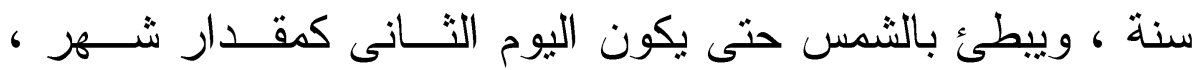

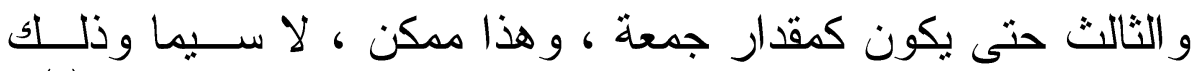

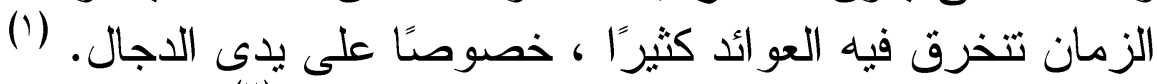

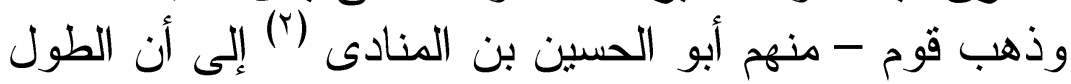

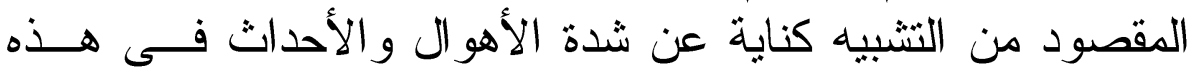

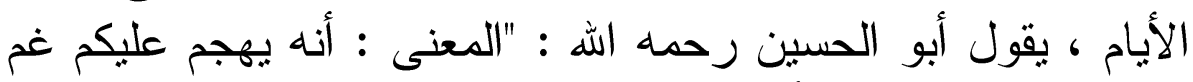

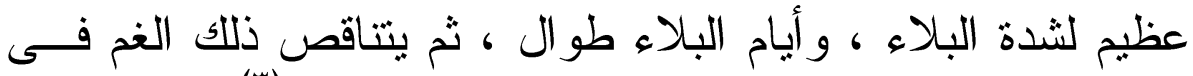

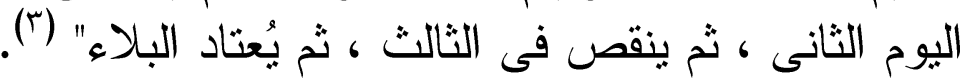

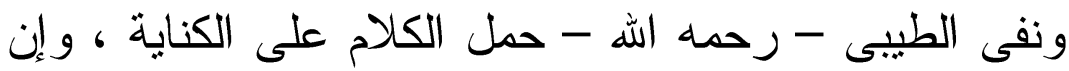
كان لابد ؛ فلا بستقيم ذلك إلا بتأويل ، يقول رحمه الله : "و لا سبيل

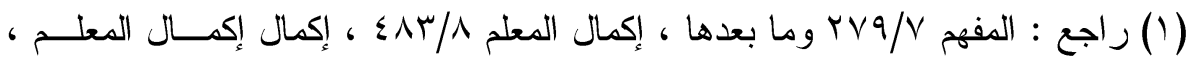

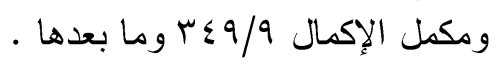

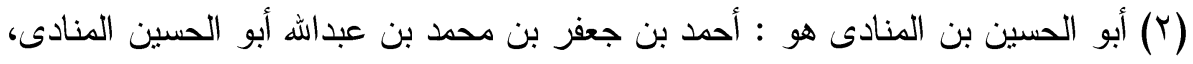

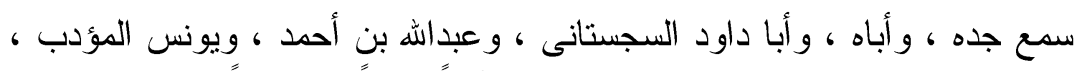

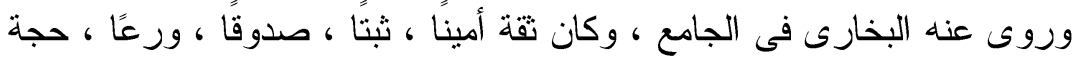

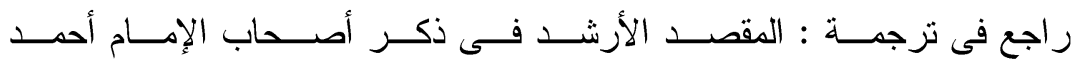

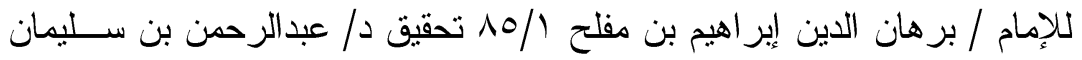

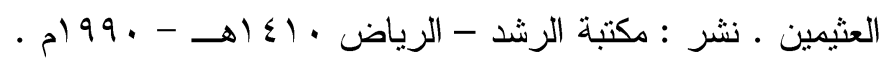

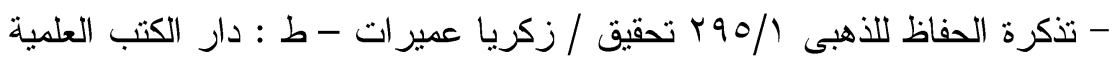

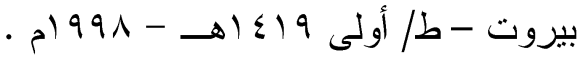

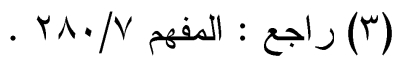


إلى تأويل امتداد تلك الأيام على أنها وصفت بالطول و الامتداد ؛ لما

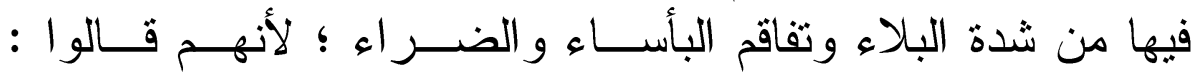

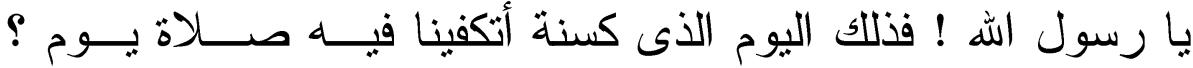

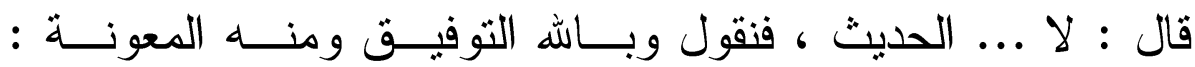

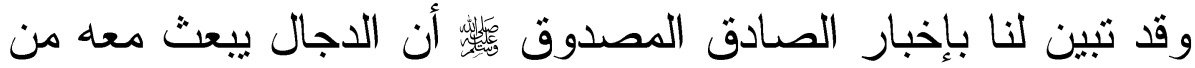

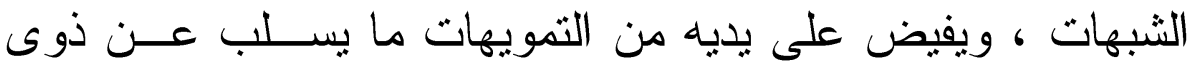

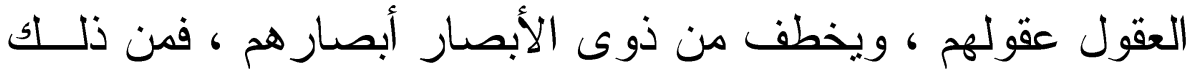

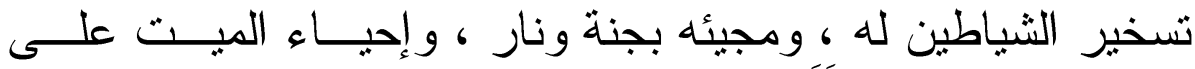

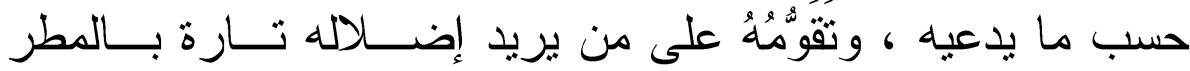

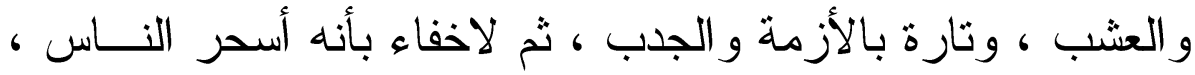

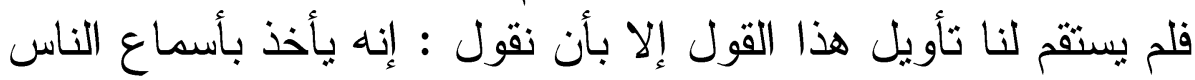

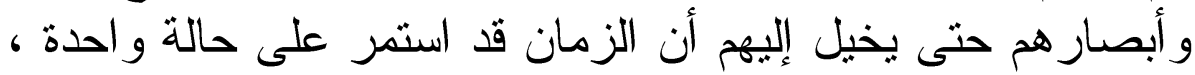

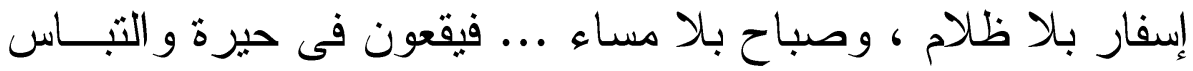

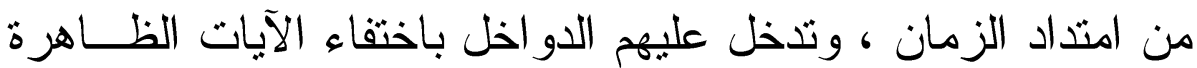

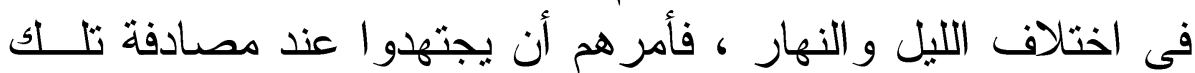

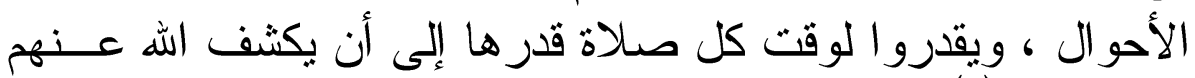

نالك الغمة" (1)

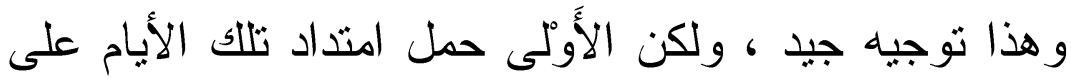

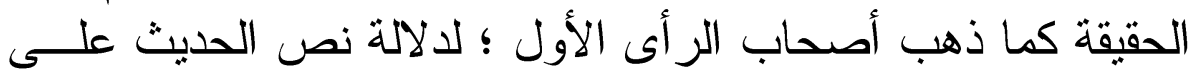

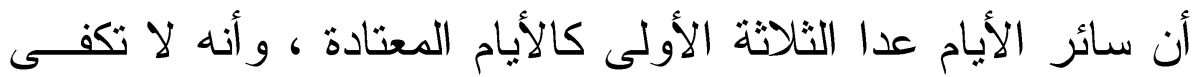

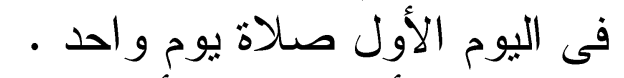
بقى أن نشير إلى أن التنكير فى : (يوم - ســنة - شـــر -

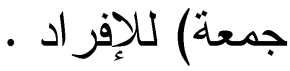

(1) راجع : الكاثف عن حقائق السنن • 1 ال وما بعدها . 


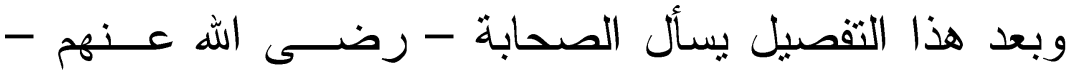

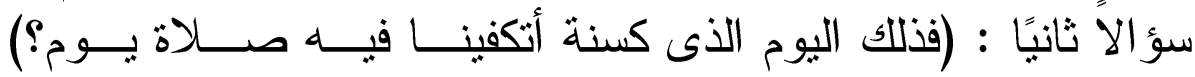

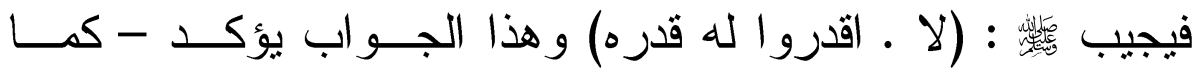

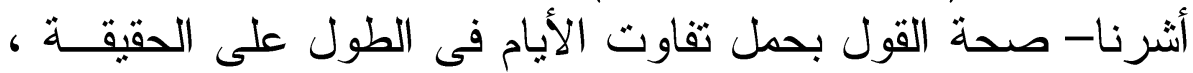

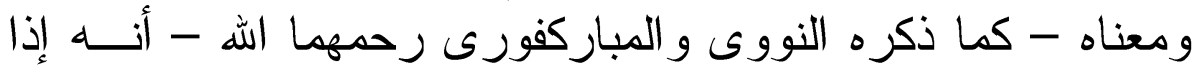

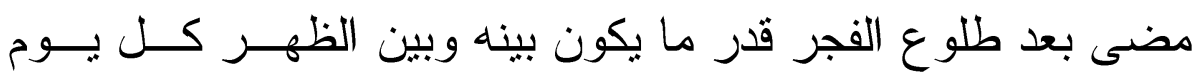

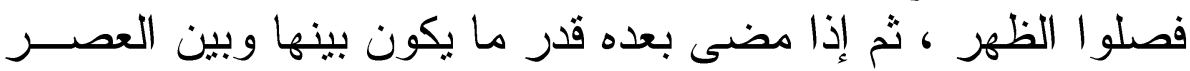

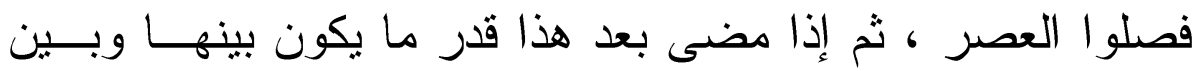

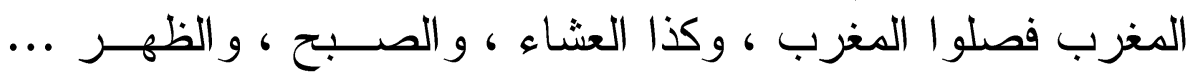

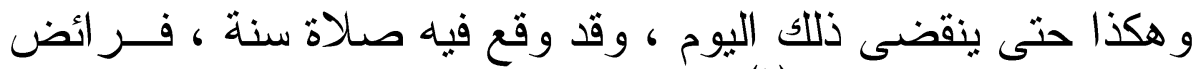

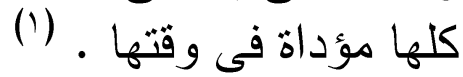

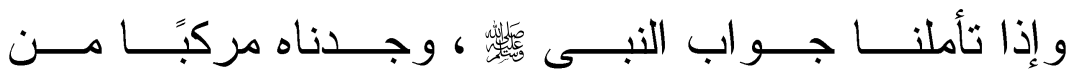

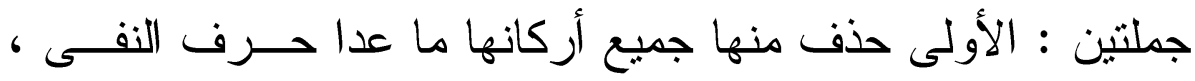

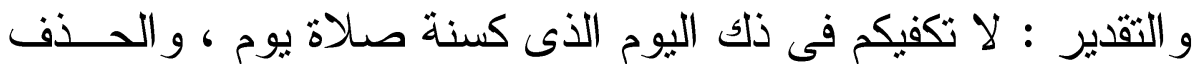

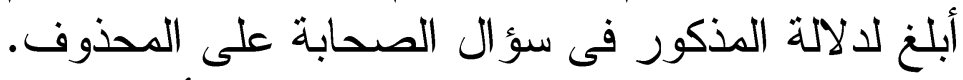

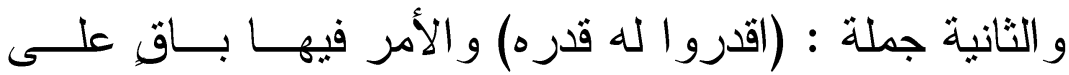

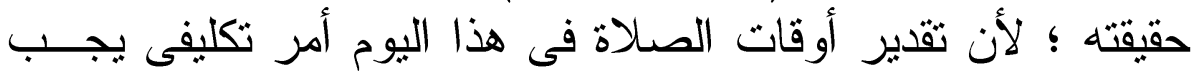

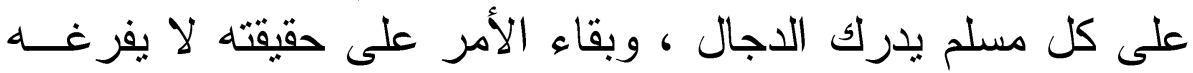
من معنى النصح و الإرشاد الذى يتطلبه حال الصحابة .

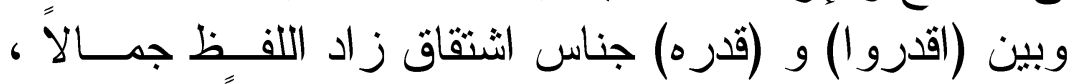
و أكسبه موسيقى ، وجعل المعنى معه أكثر توكيدًا وتثبيتًا .

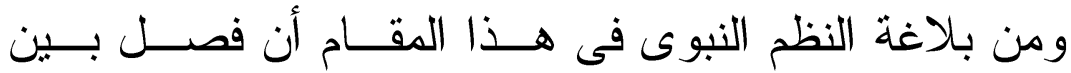

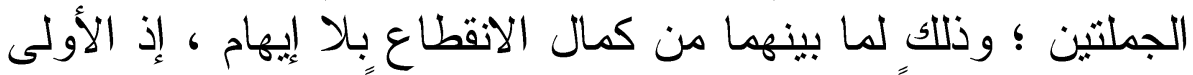

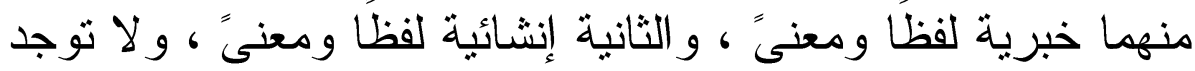


بينهما جهة جامعة تسوغ العطف ، كما لا بوقع الفصل بينهما فـى

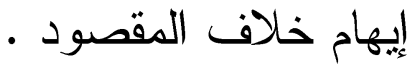

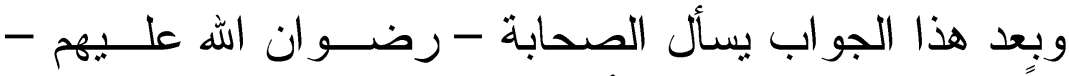

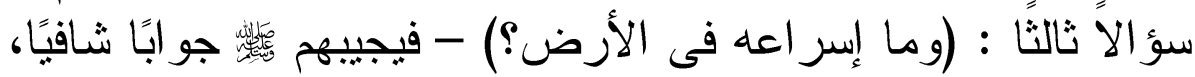

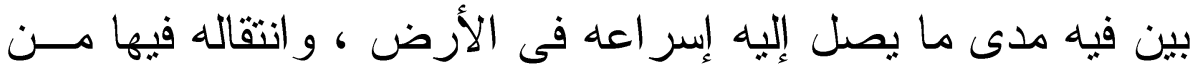

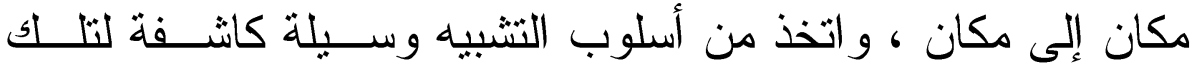

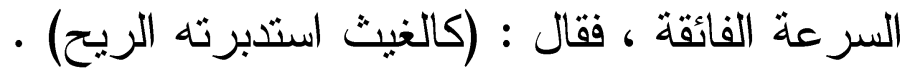

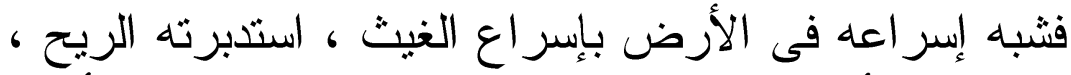

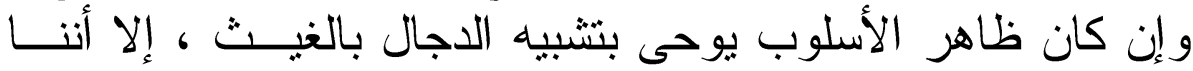

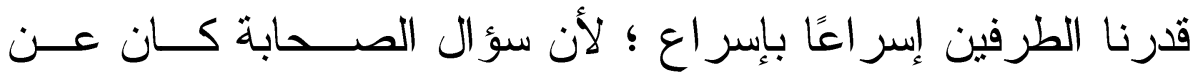

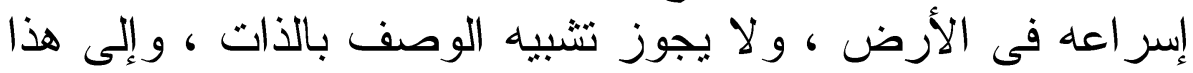

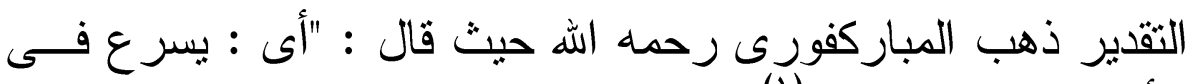

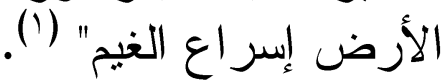

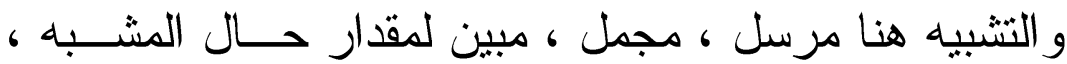

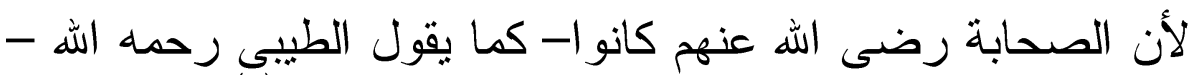
يعلمون أن له إسر اعًا فى الأرض فسألو الهن عن كيفيته (Y).

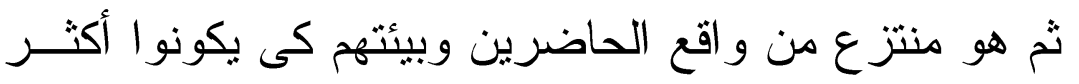

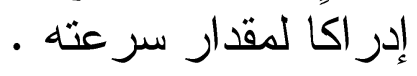

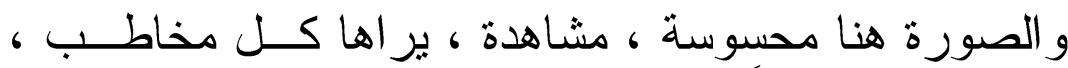

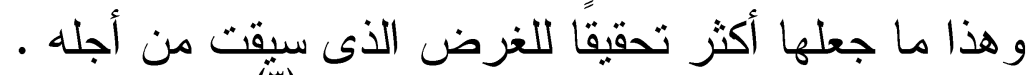

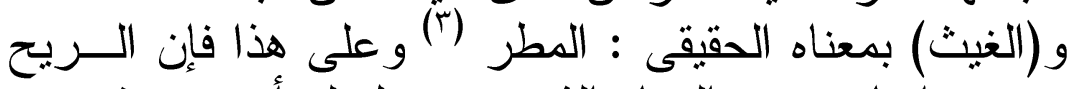

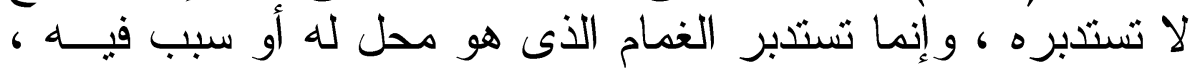

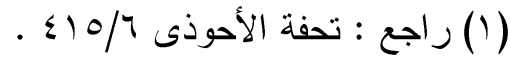

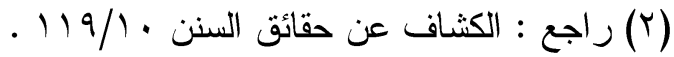

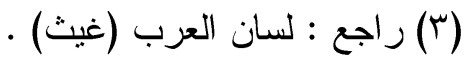




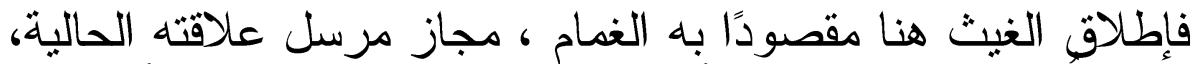

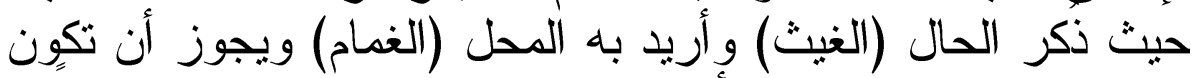

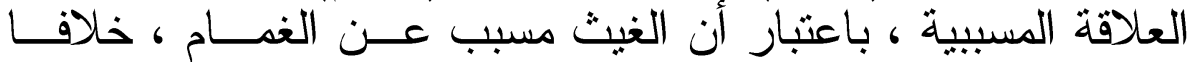

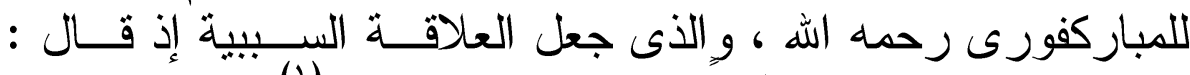

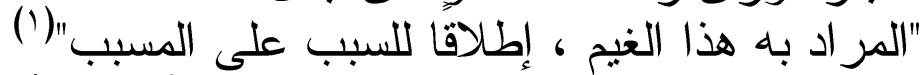

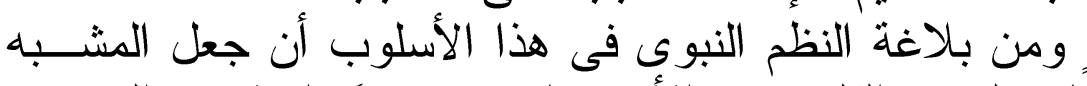

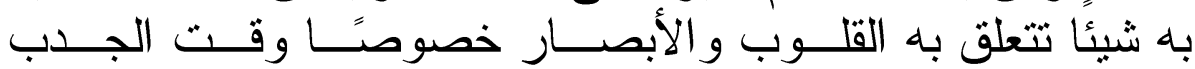

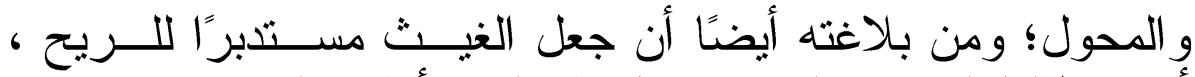

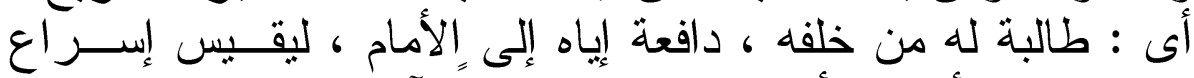

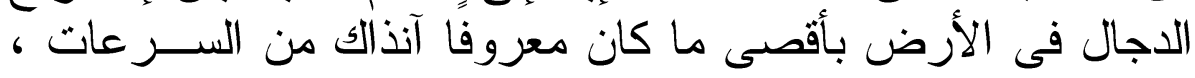

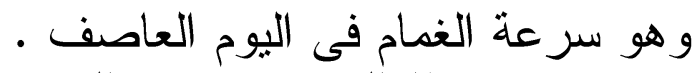

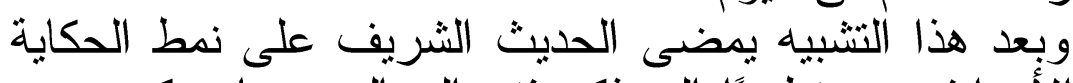

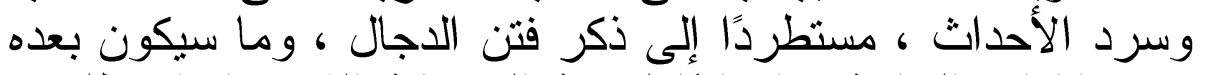

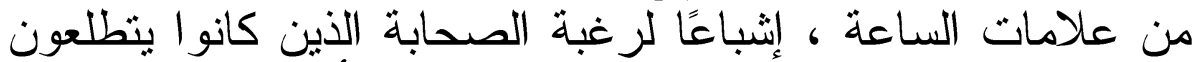

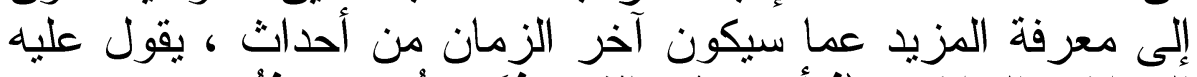

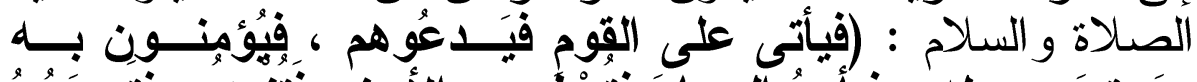

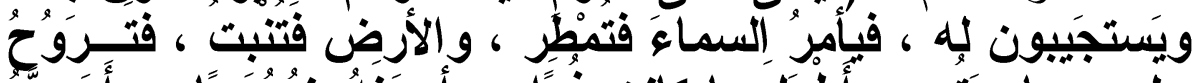

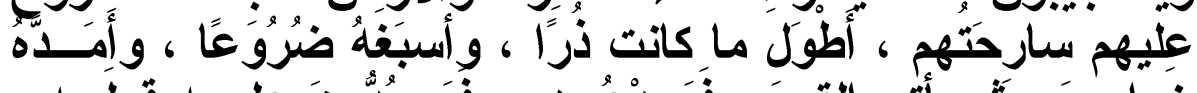

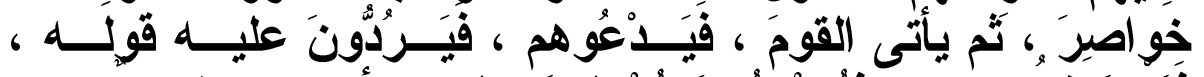

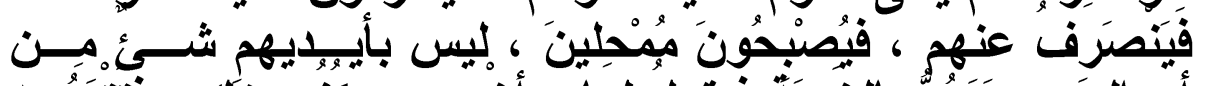

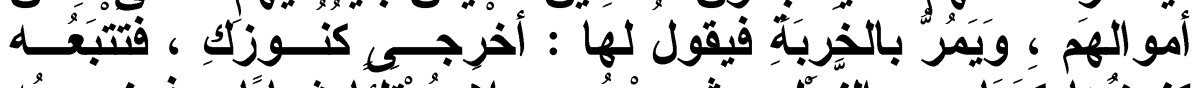

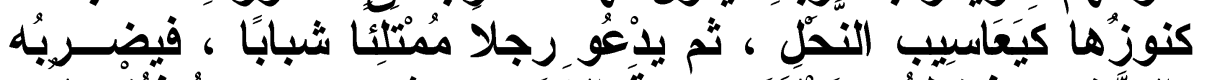

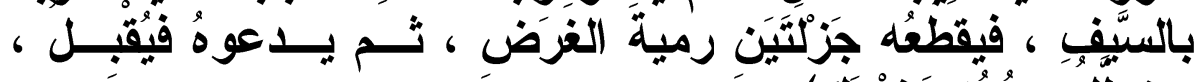

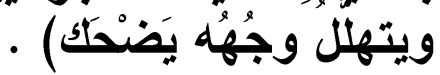

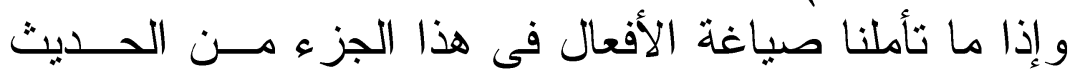

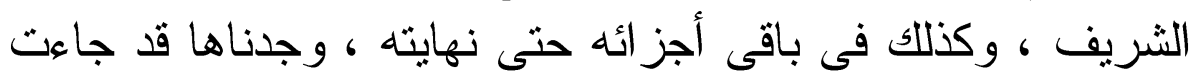

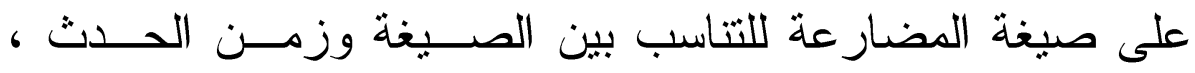




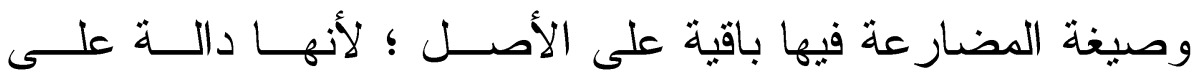

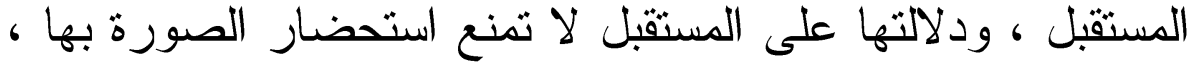

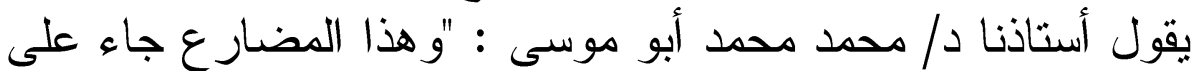

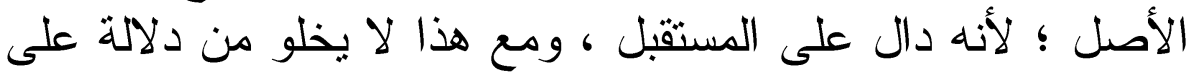

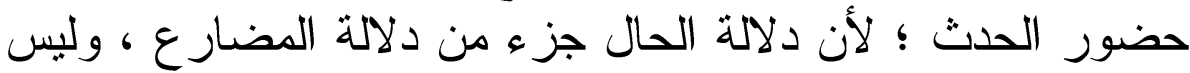

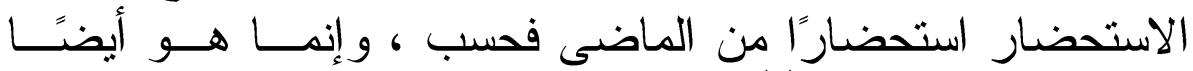
إحضار من المستقبل" (1)

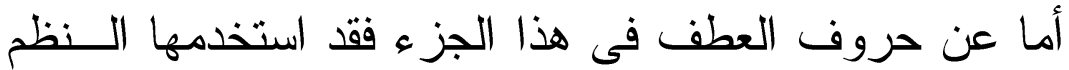

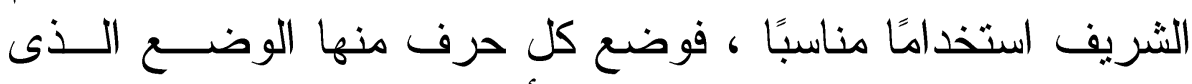

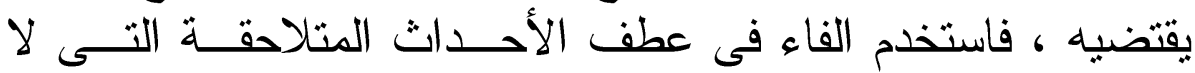

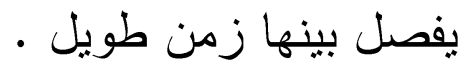

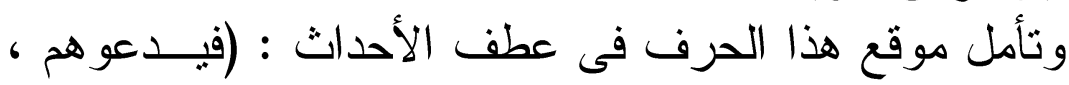

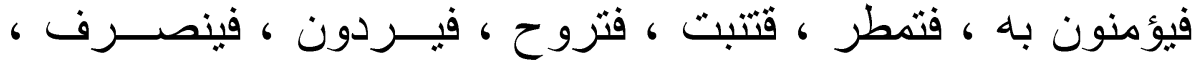

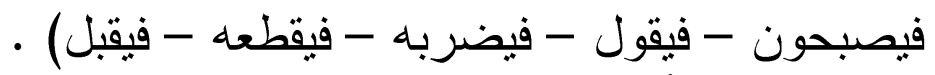

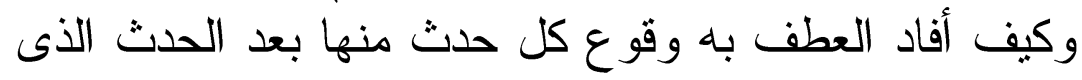
قبله مباشرة دون فاصل زمنى .

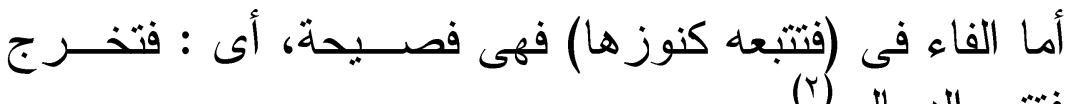

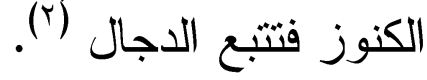
وحينما ير اد الجمع بين الأحداث نرى النظم الشريف بيتخدم

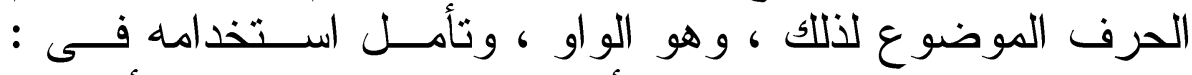

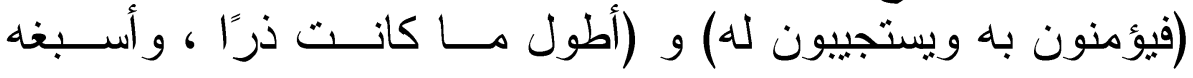

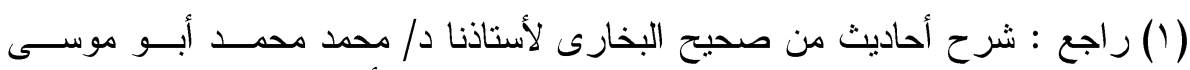

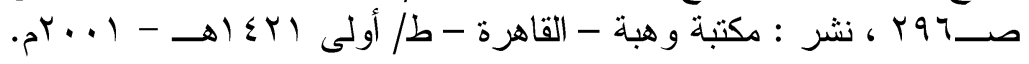

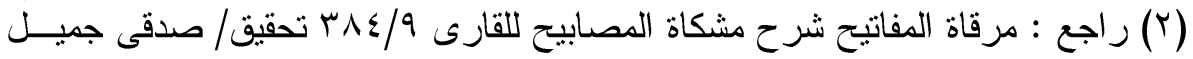

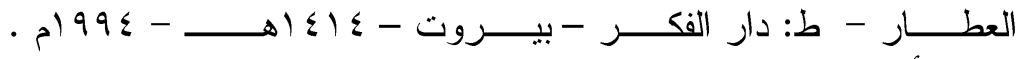

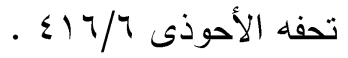




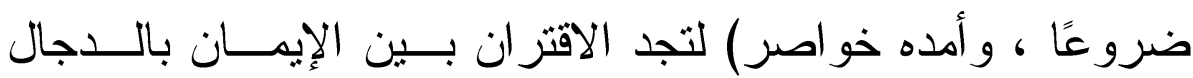

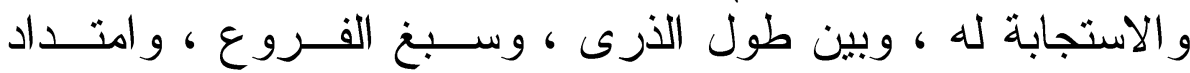

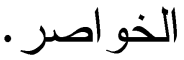

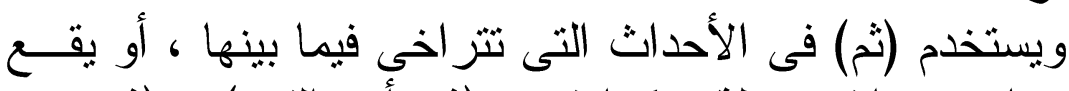

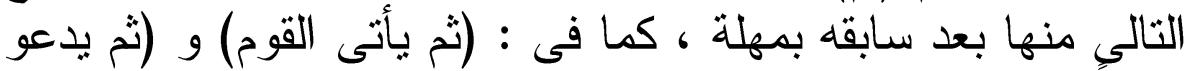

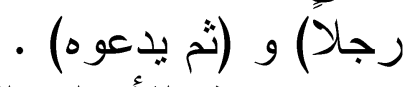

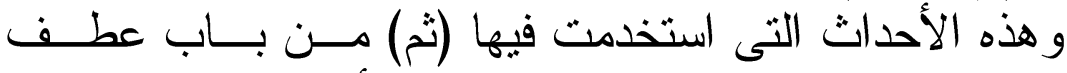

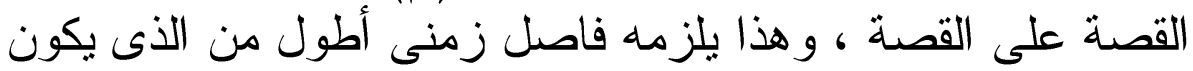

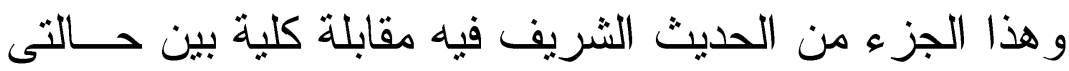

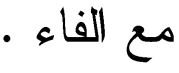

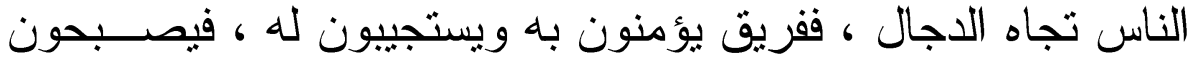

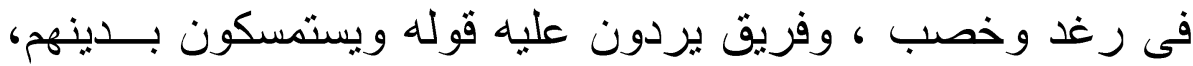

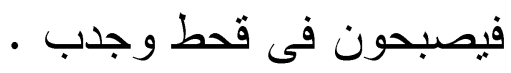

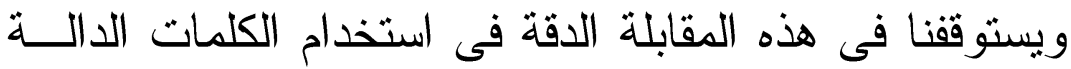

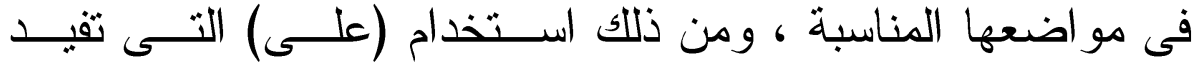

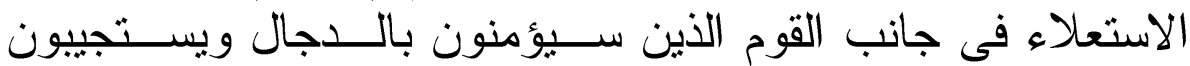

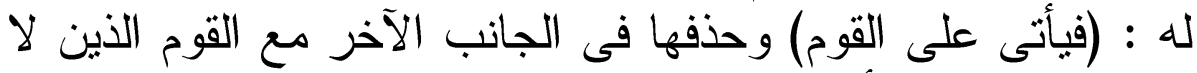

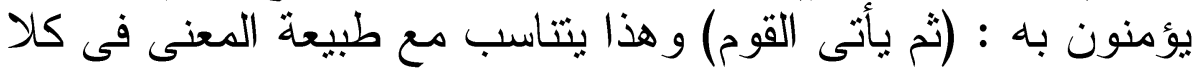

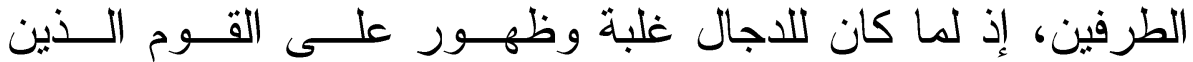

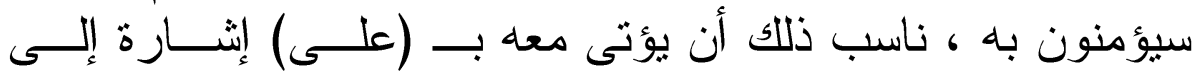

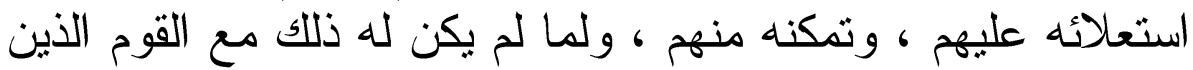

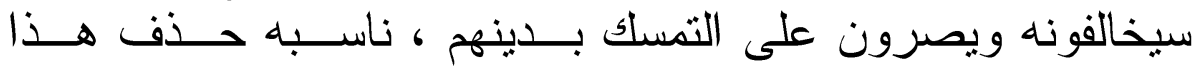

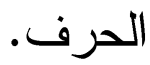

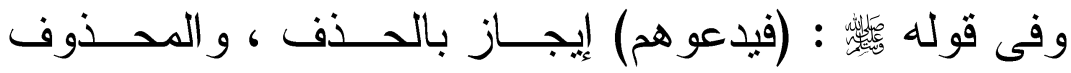

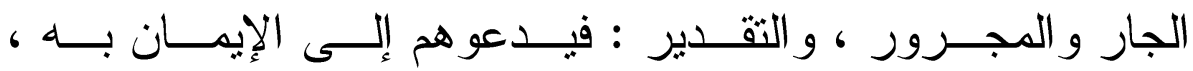

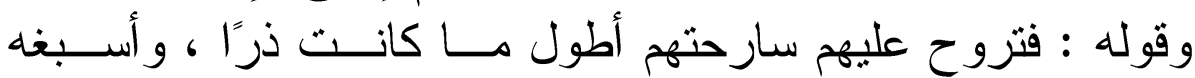

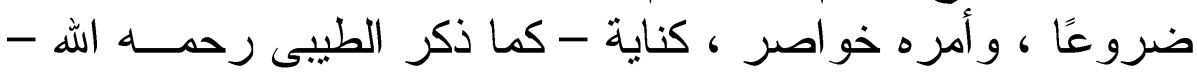


عن الامنلاء وكثرة الأكل و اللبن (') و الكناية هنا تلويحيه بعيدة انتقل فيها النظم الثريف من كثرة النبات و ازدهار الأرض بالخضــرة ،

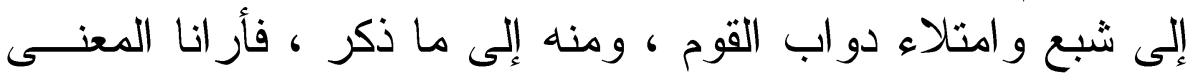
بطريق لطيف لا تز اه فيه - كما يقول أستاذنا د/ أبو موسى - يدنو

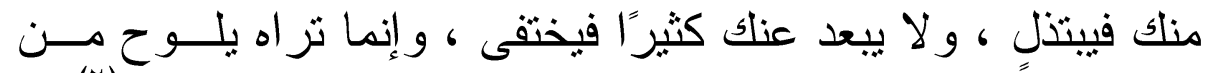

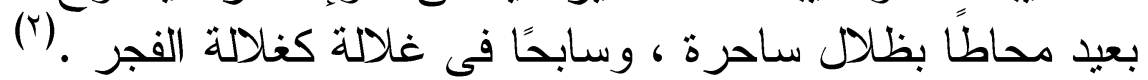

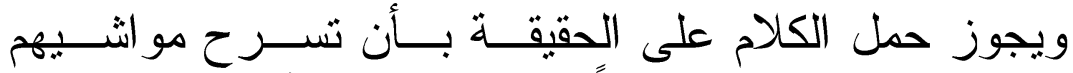

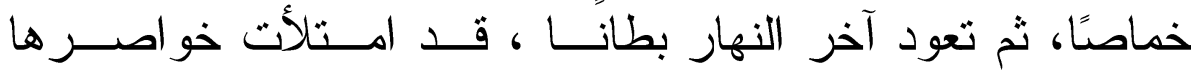

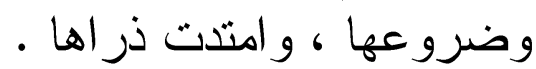

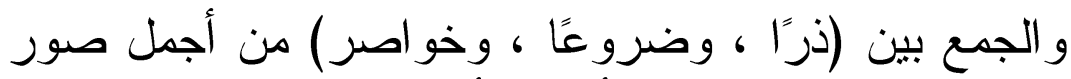

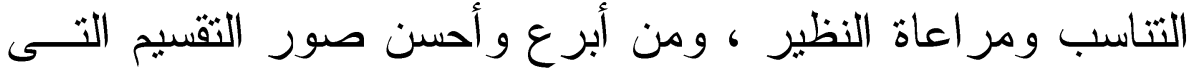

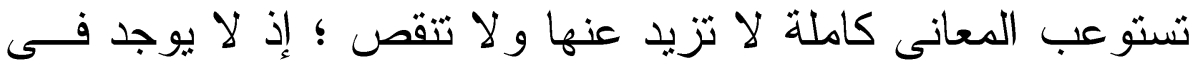

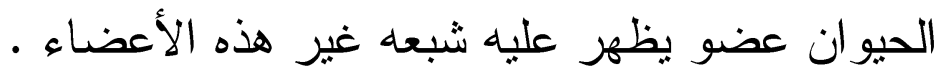

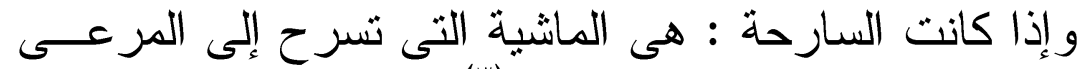

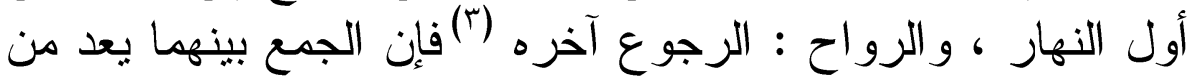

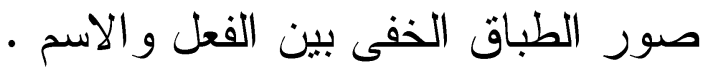
و التعبيز باسم الفاعل (سارحة) بدلاً من : مو اشيهم أو دوابهم

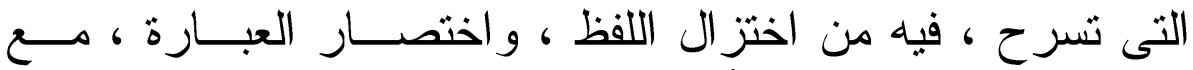

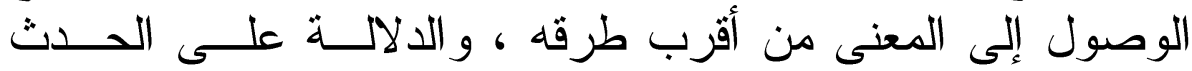

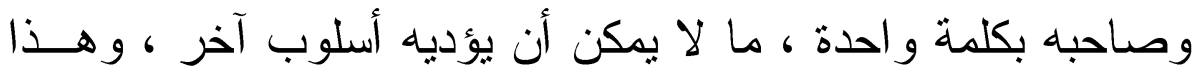

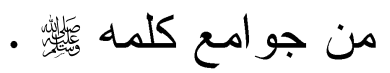

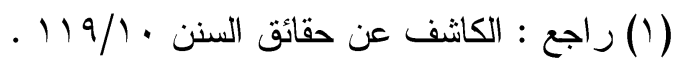

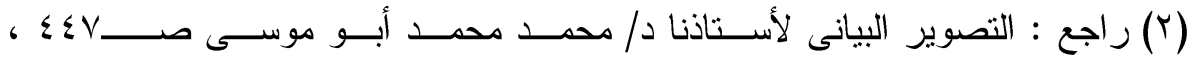

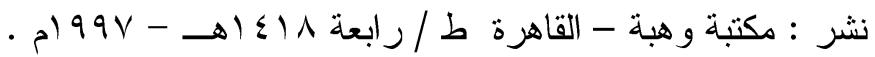
(ب) راجع : لسان العرب : (سرح - روح) : لشئه 


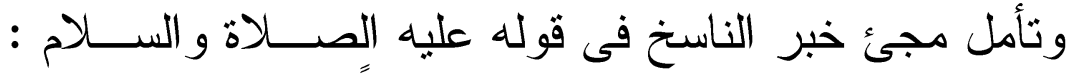

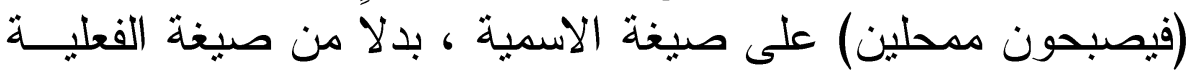

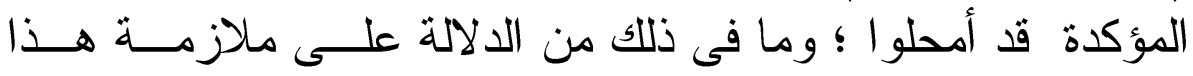

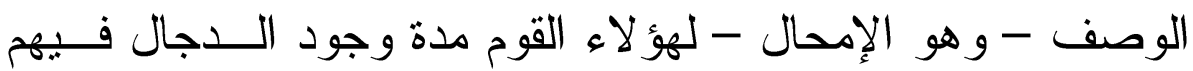

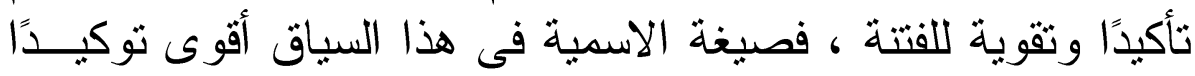

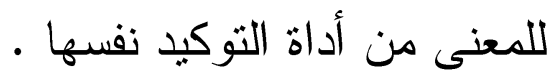
وتأمل روعة البيان النبوى وبلاغته في تصويل تصوير حالة البؤس

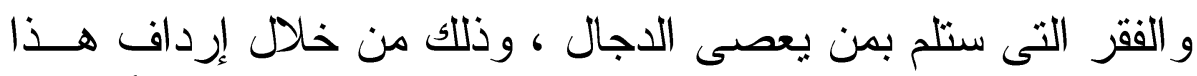

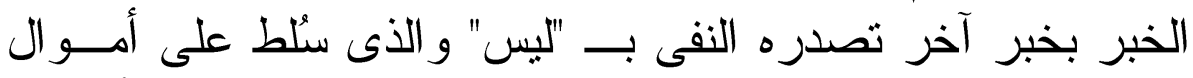

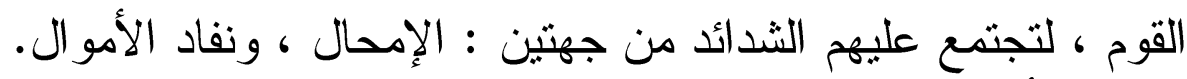

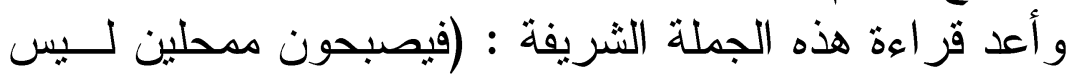

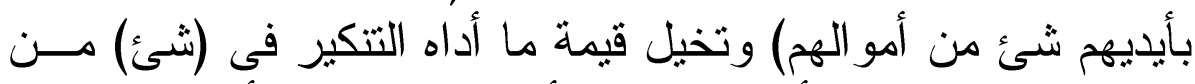

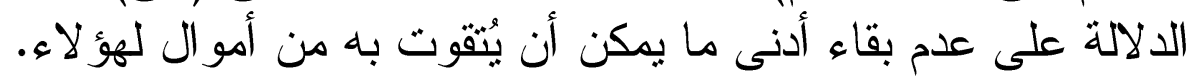

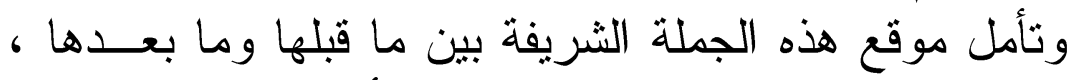

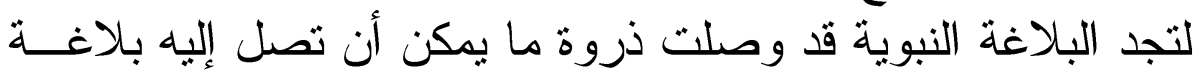

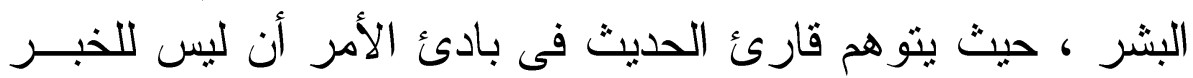

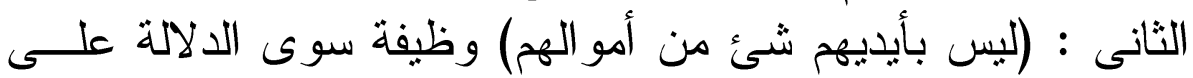

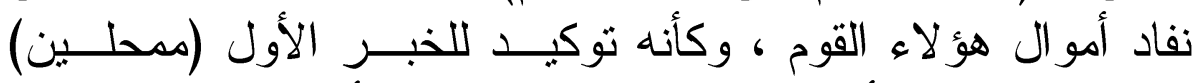

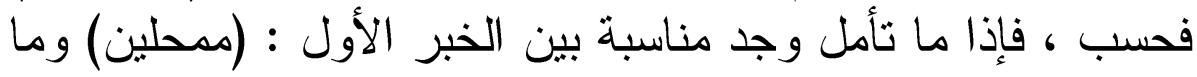

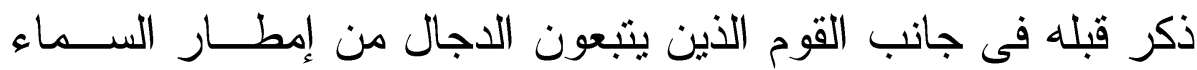

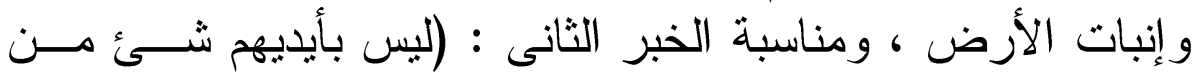

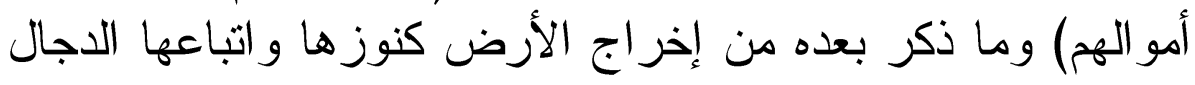

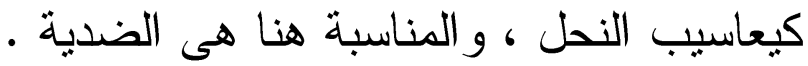

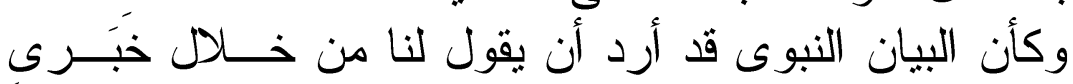

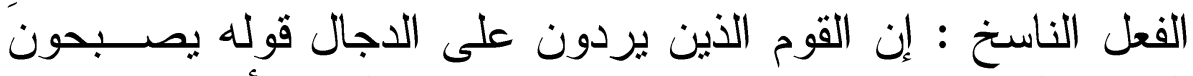
(ممحلين) فى حال خصب ونماء من يتبعونه (ليس بأيديهم شئ من لأن 


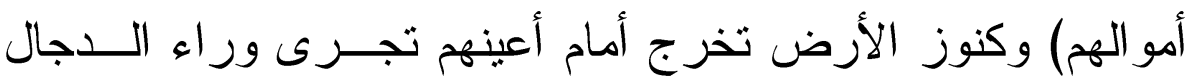

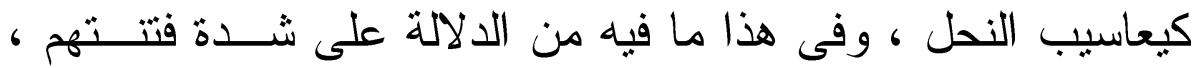

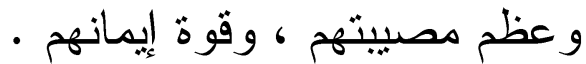

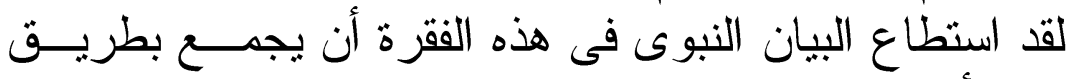

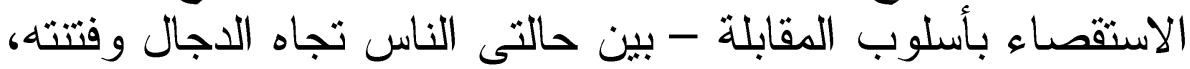

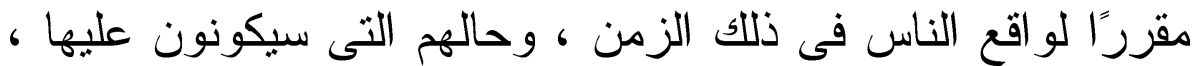

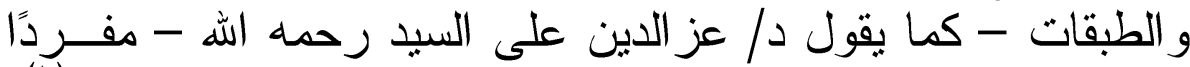

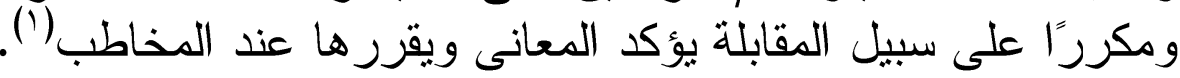

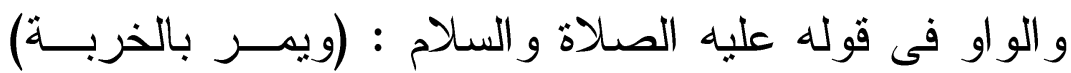

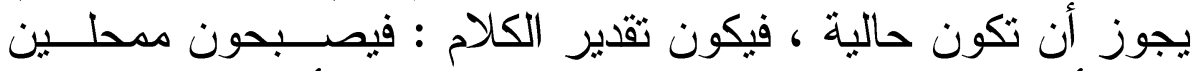

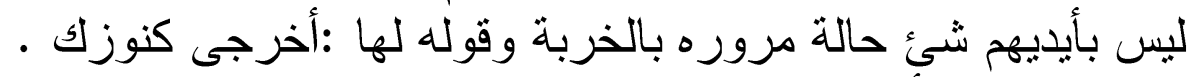

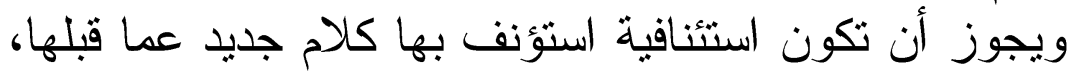

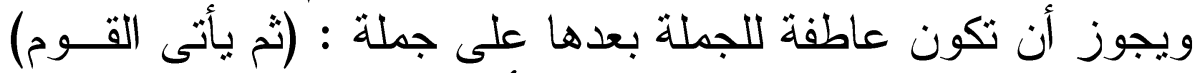

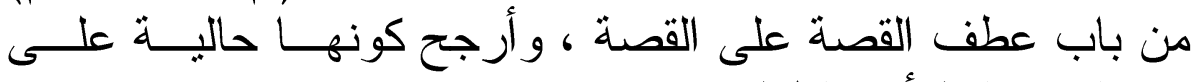
كونها استئنافية أو عاطفة الفهة . وفى قوله عليه الصلاة و السلام : (ويمر بالخربــة إيجـة إيجـاز

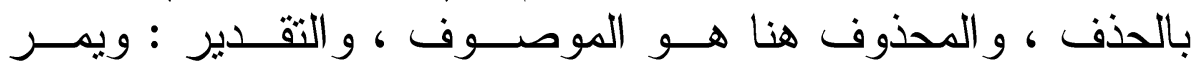
بالأرض الخربة ، و السر البلاغى من ور اء هذو هذا الحذف هو التركيز

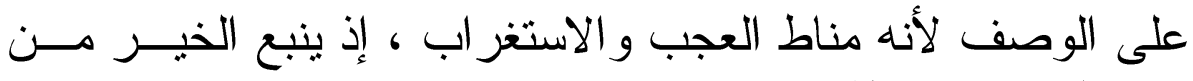

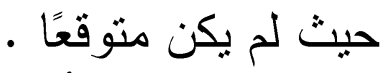

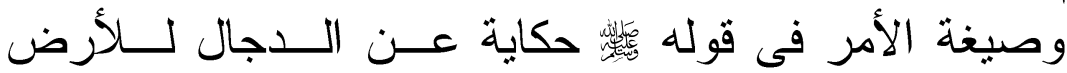

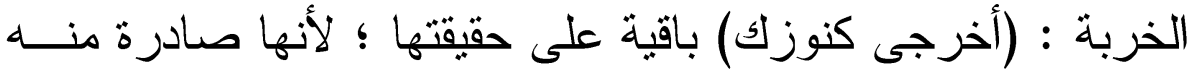

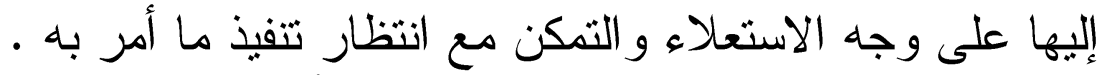

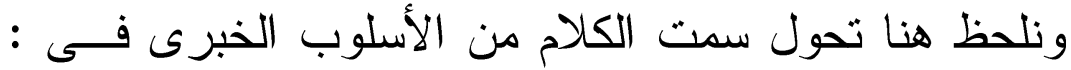

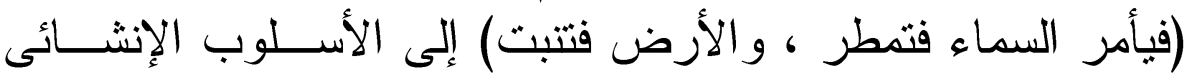


الصريح : (أخرجى كنوزك) إذا لو جرى الكلام على سمث و احد ،

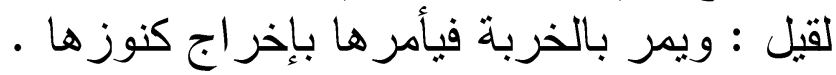

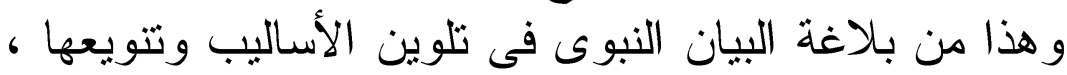
كى تجذب الانتباه ، وتستحوذ على مجاهع الحسـ و الإدر الك لـدى لـونى المثلقى

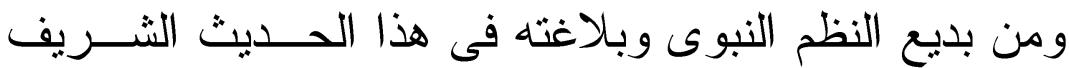

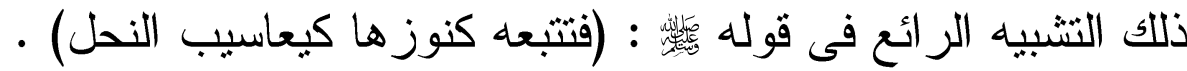

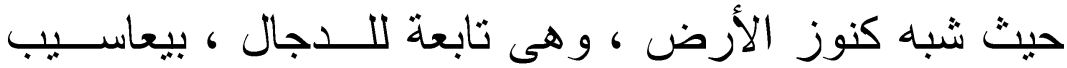
النحل ، وهو تشبيه مرسل ، مجمل ، مبين لحال المشبه من الكثرة،

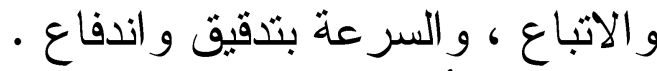

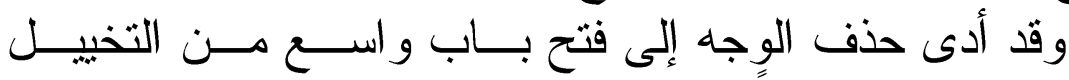

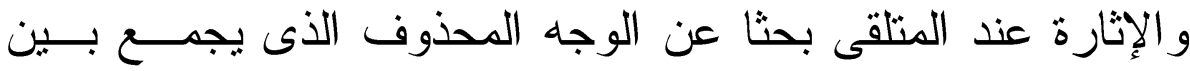
الطرفين ؛ لتذهب فى تقديره كل نفس المذهب الذى تر اه ، مع تقليل اللفظ ، و إيجاز العبارة .

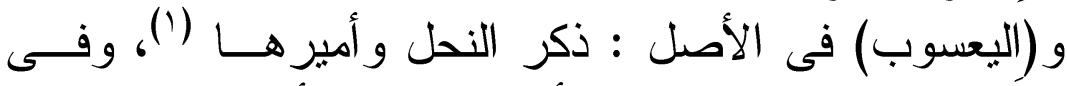
المثل : بكر بُكور البعسوب ، يربد أمبر النحل ؛ لأنها تثبعه غــدوة إلى عملها (r) ونظرًا لأن التشبيه بالعيسوب نفسه لا يحقق الغــرض مــن

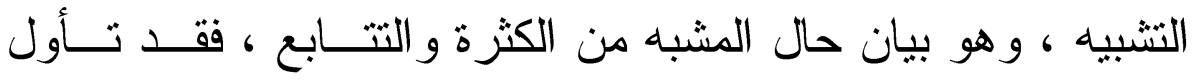

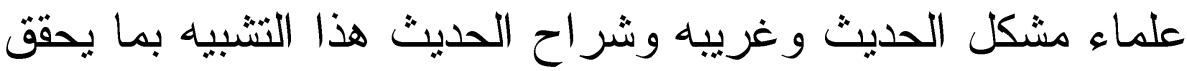

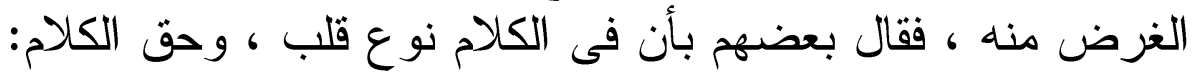

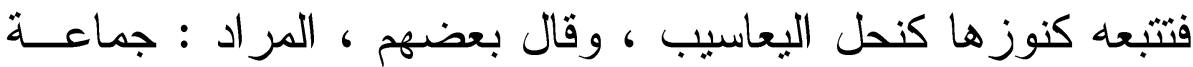

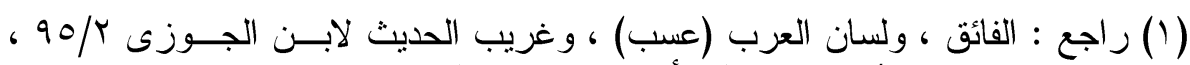

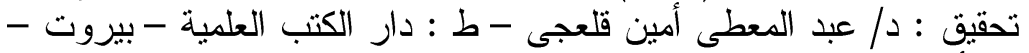

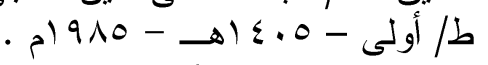

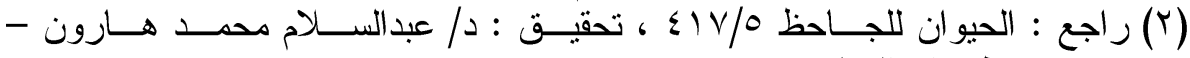

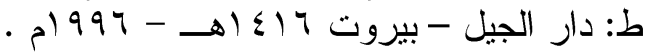


النحل لا ذكورها خاصة ، لكنه كنى عن الجماعة بالعيسوب ، وهو

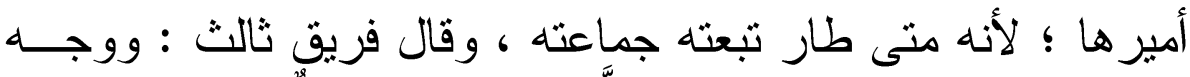

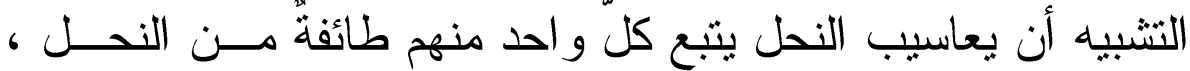

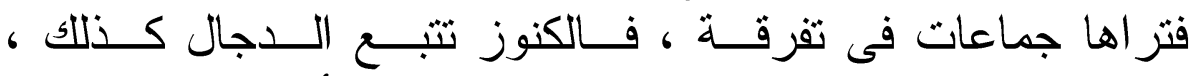

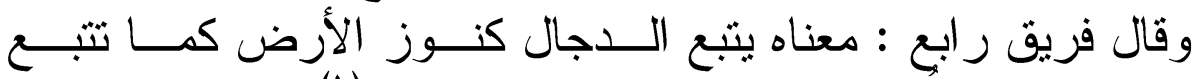

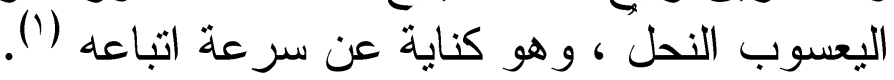

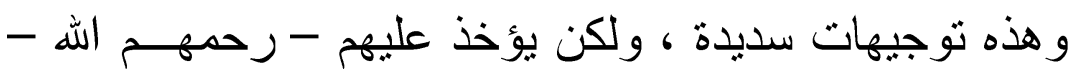

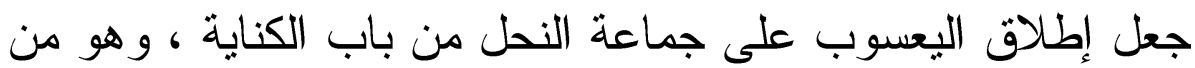

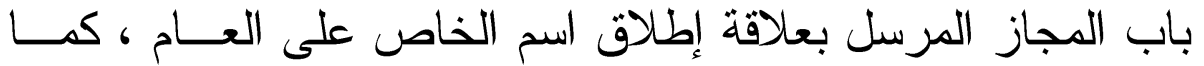

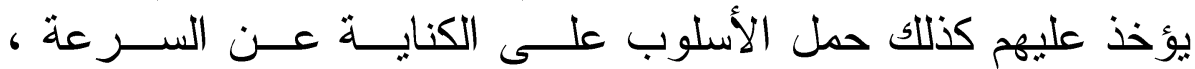

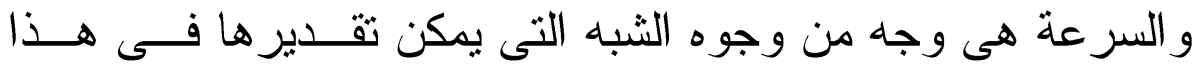

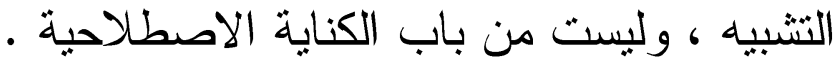

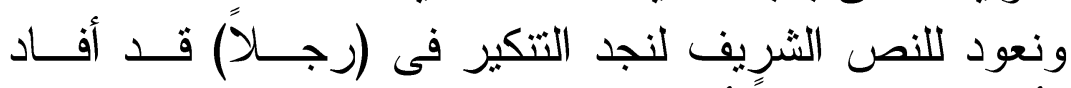

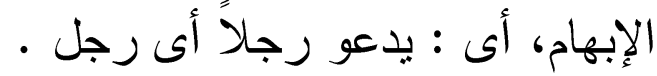

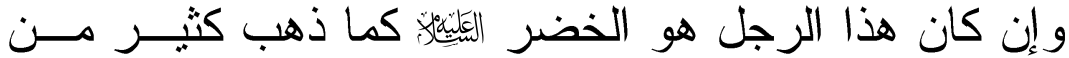

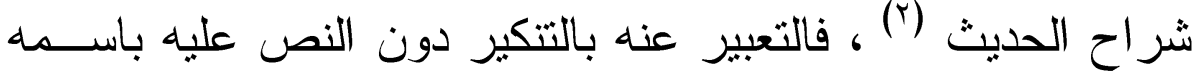

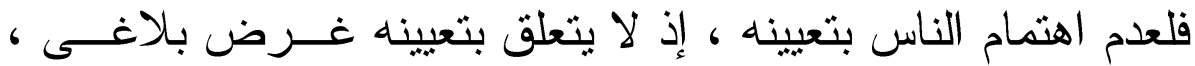
و إنما الاهتمام هنا بالحدث دون الأشخاص الذين سيقع عليه .

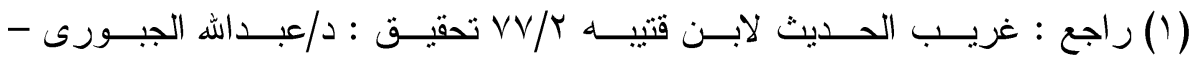

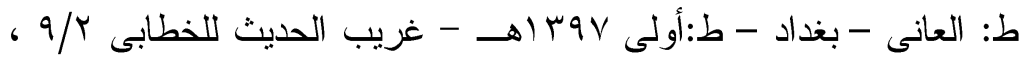

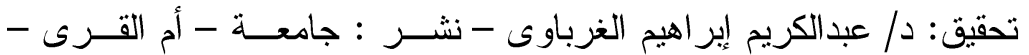

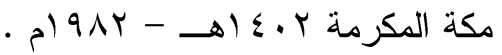

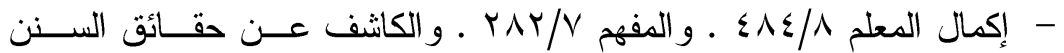

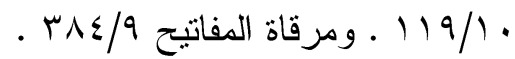

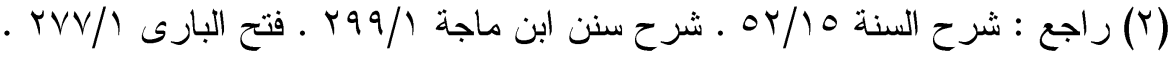




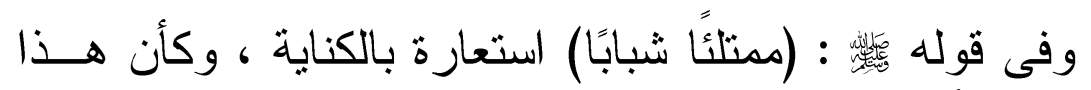

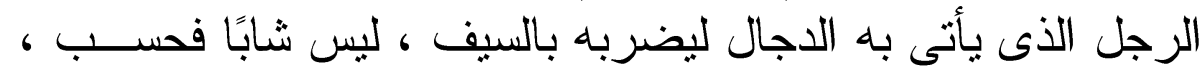

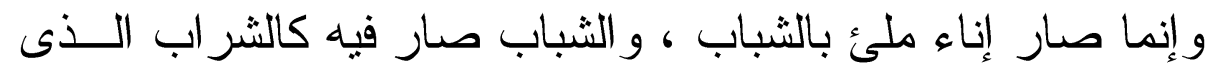

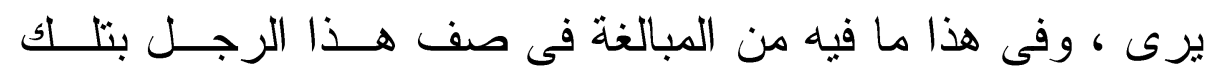

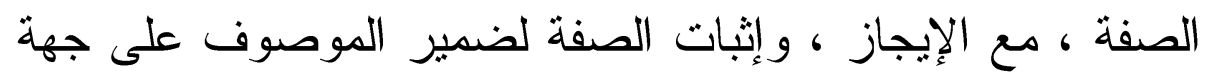

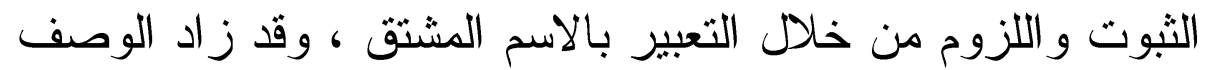

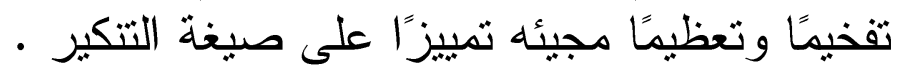

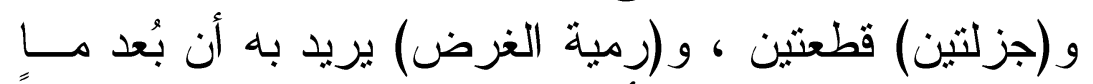

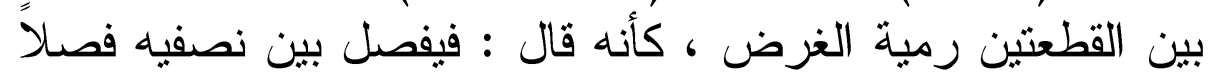

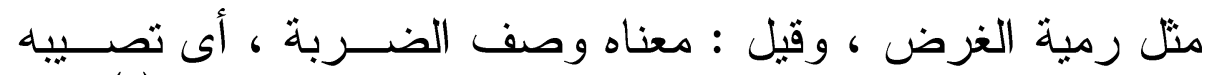

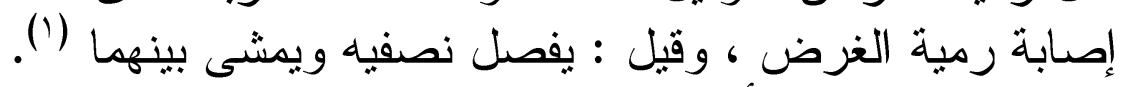

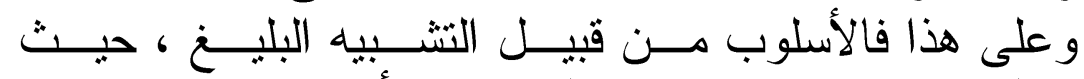

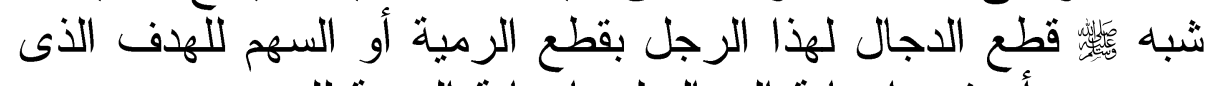

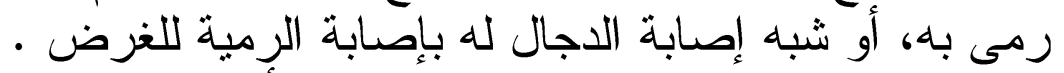

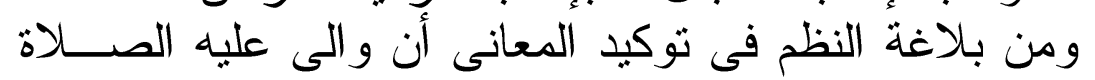

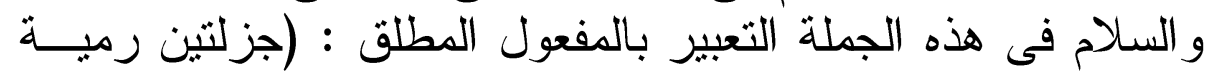

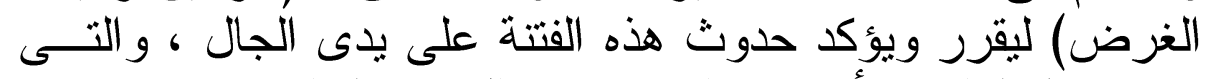

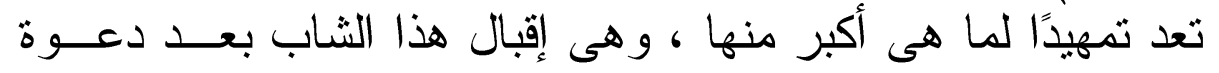

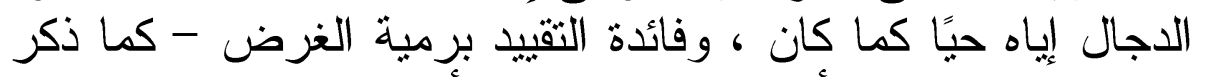

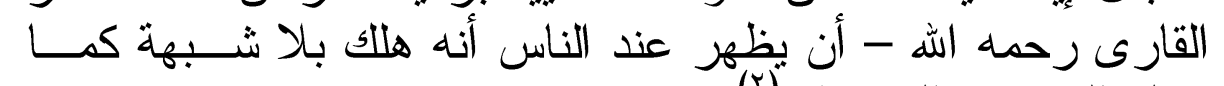

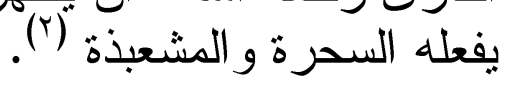

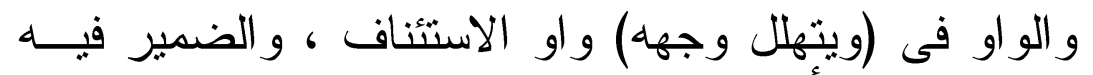

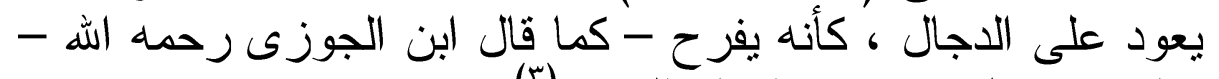

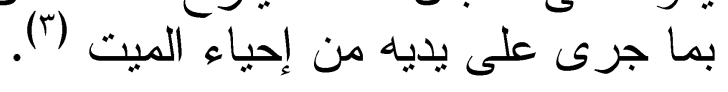

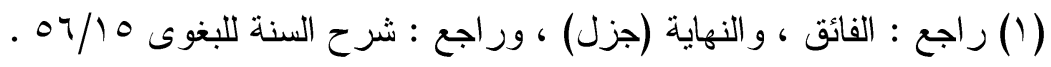

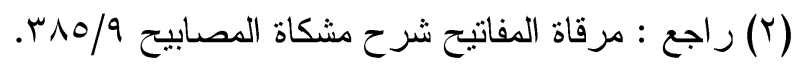

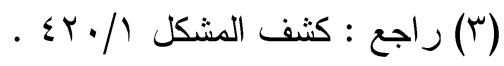




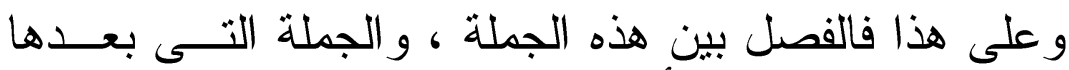

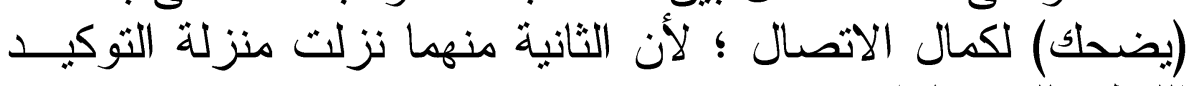

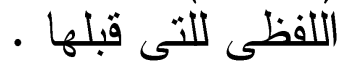

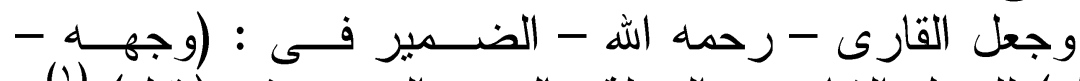

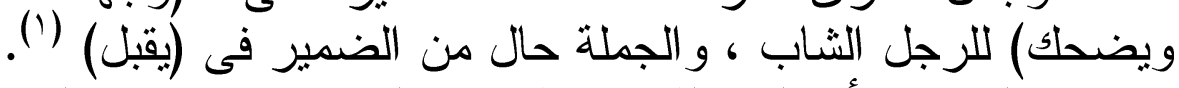

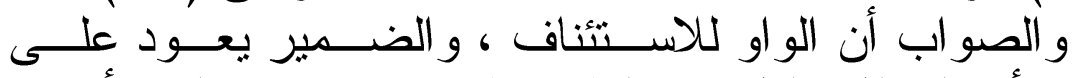

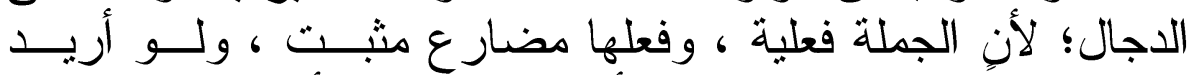

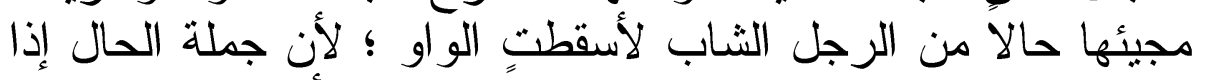

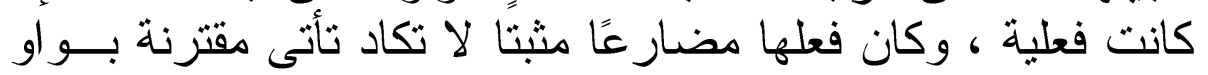

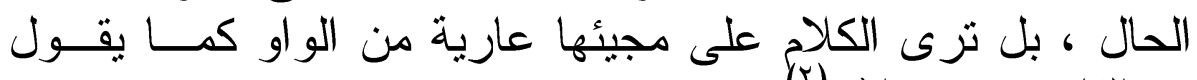
عبدالقاهر رحمه اله ب( برى 


\section{نزول عيسى المغيم وقتله الدجال \\ وخروح يأجوح وهأجوح ونهايتهم}

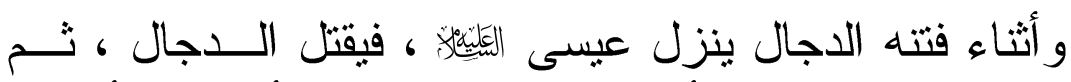

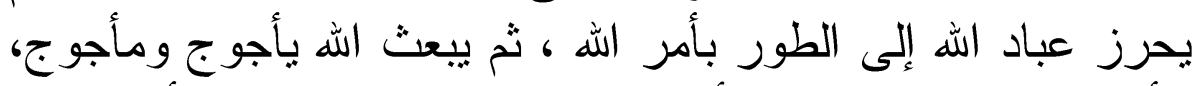

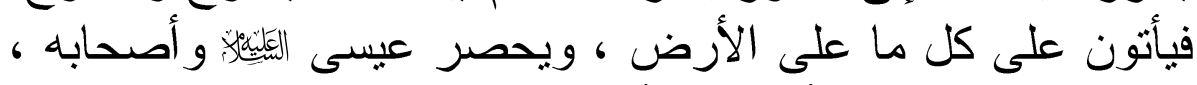

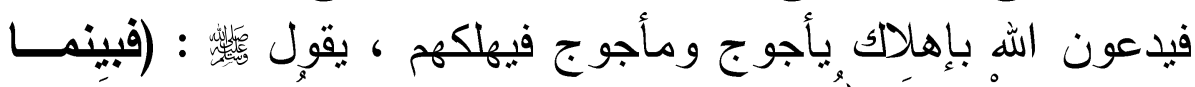

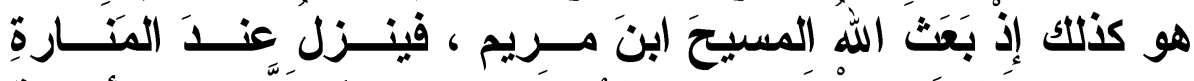

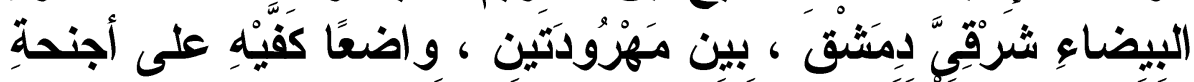

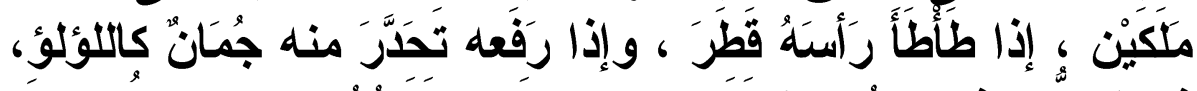

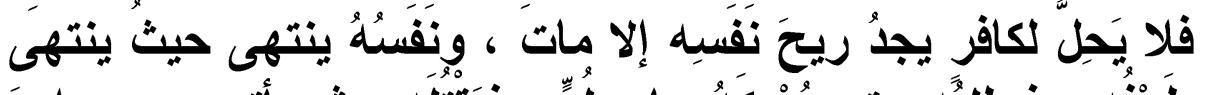

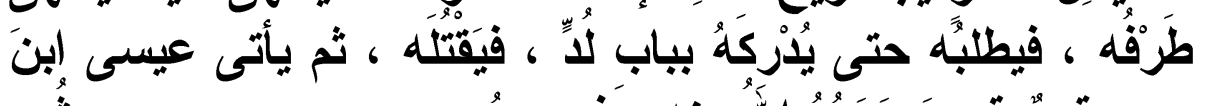

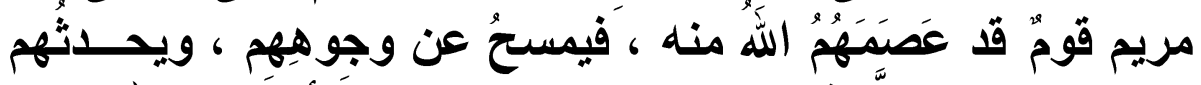

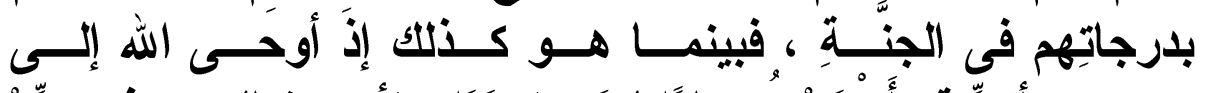

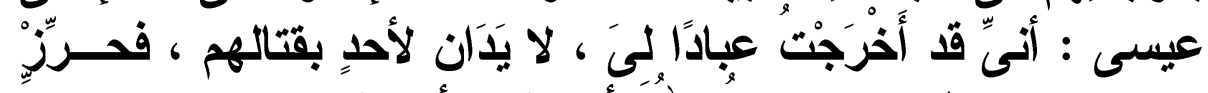

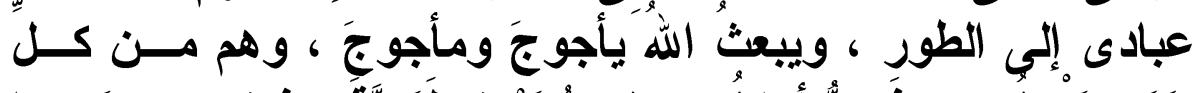

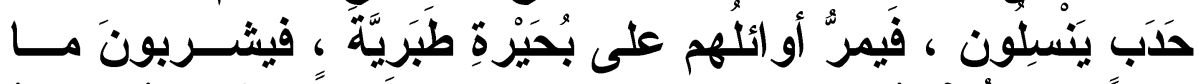

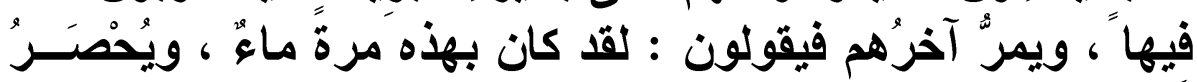

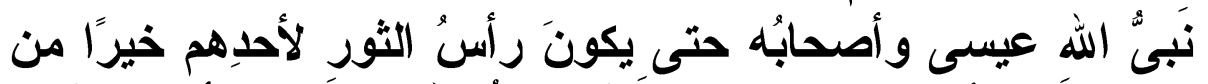

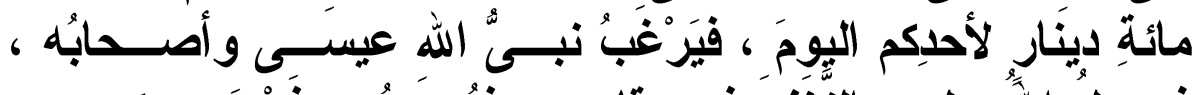

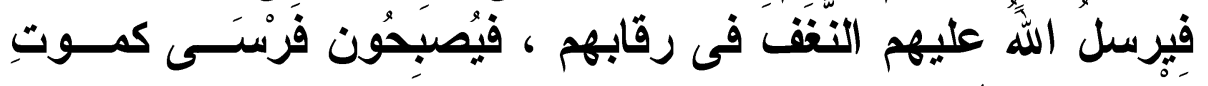

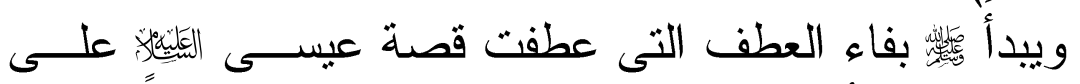

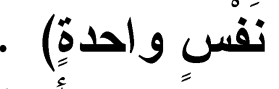

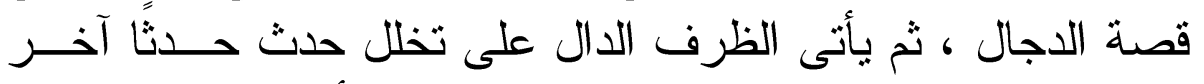

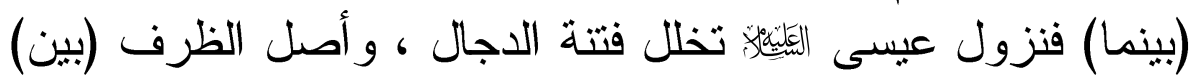




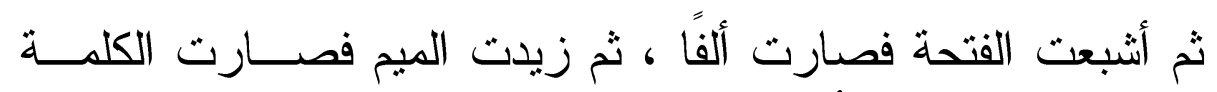

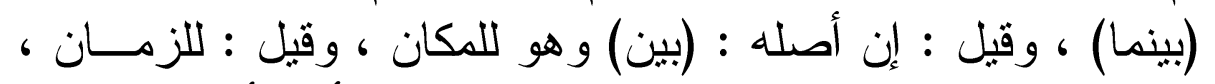

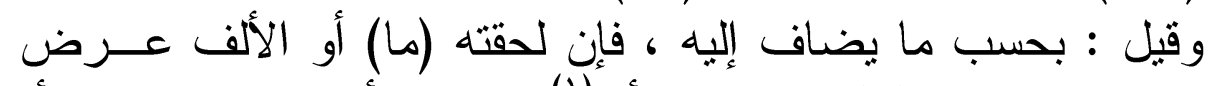

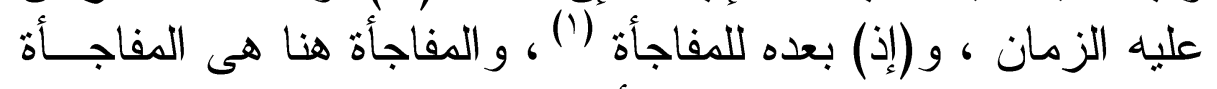

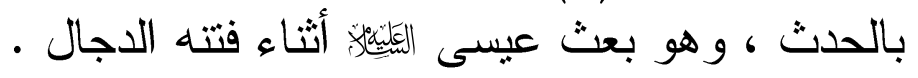

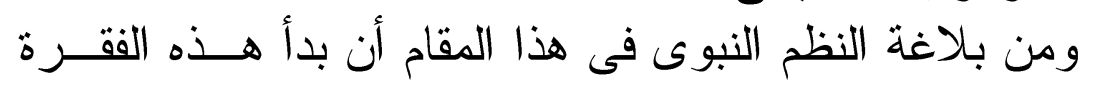

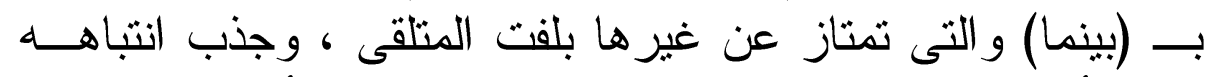

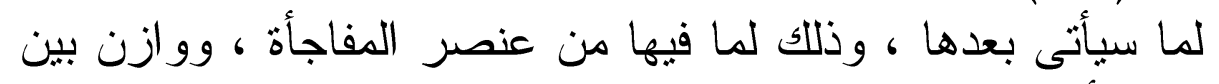

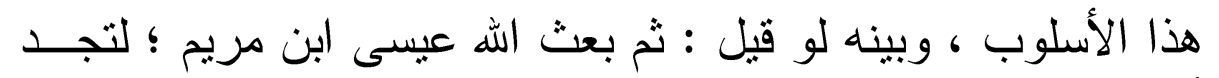

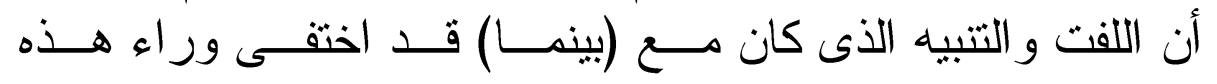

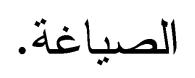

وتأمل قيمة التعبير بصيغة المضى فى (بعث) وما أضفاه من

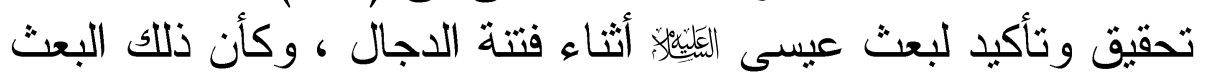

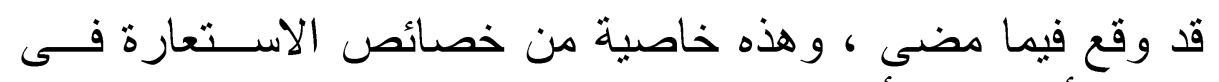

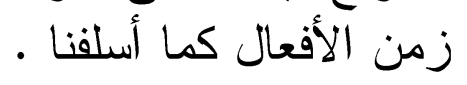

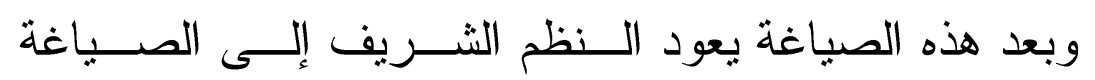

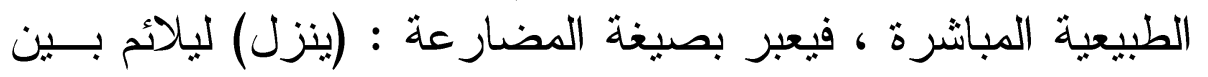

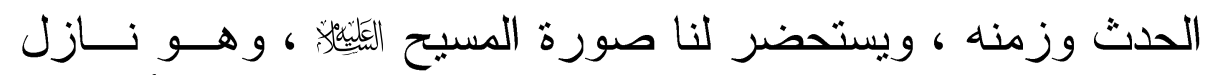

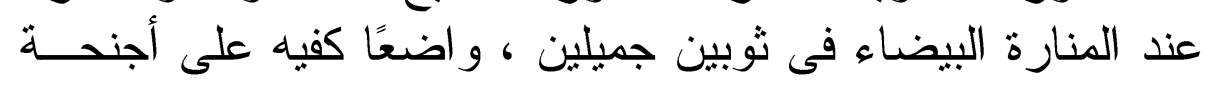

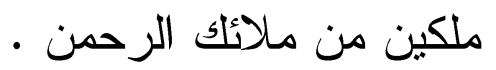

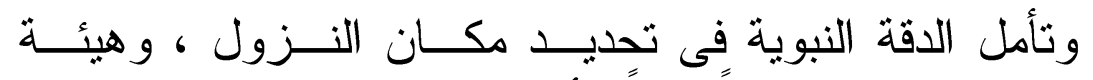

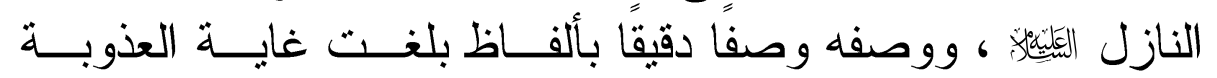

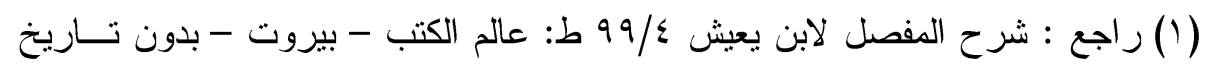

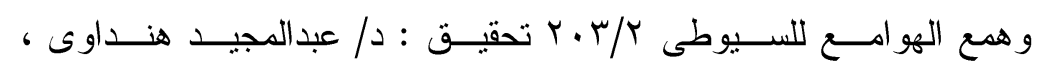

نشر : المكتبة التوفيقية - مصر - بدون تاريخ ل 


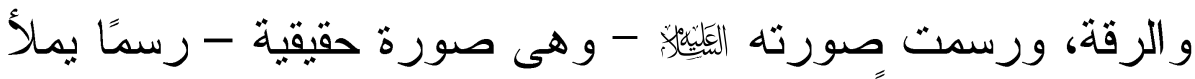

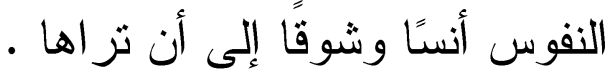

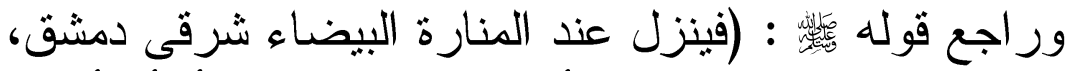

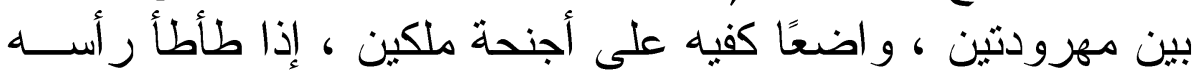

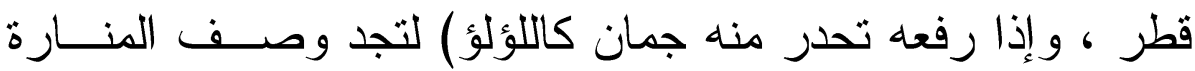

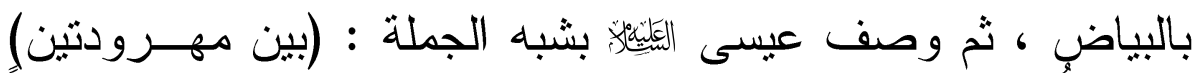

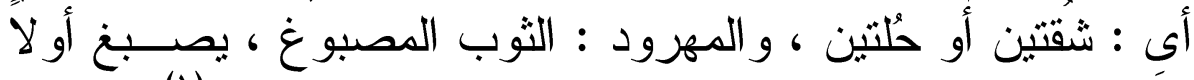

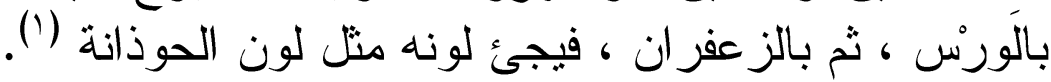

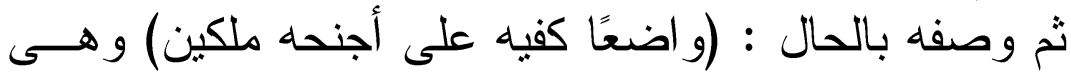

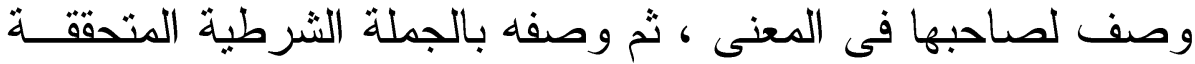

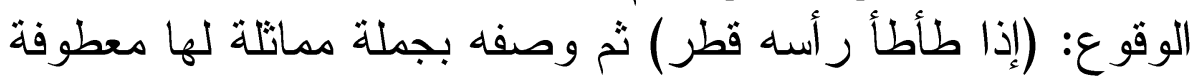

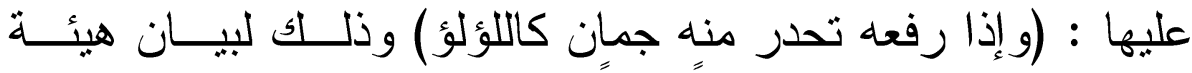
عيسى التى سينزل عليها بيانا دقيقا .

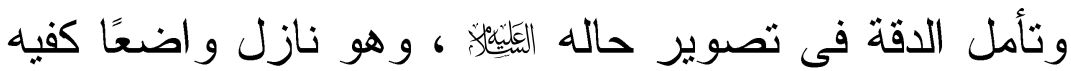

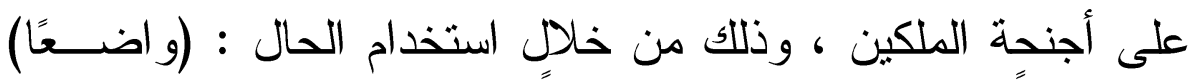

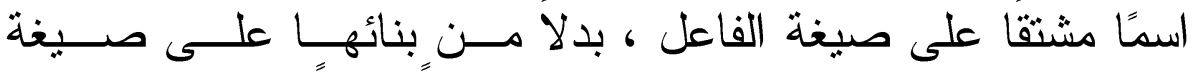

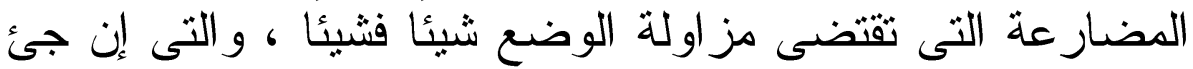

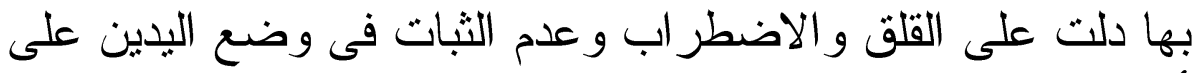
أجنحة الملكين.

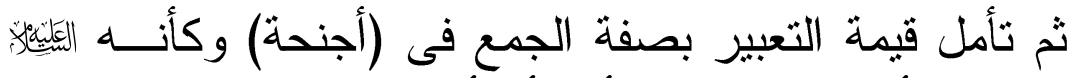

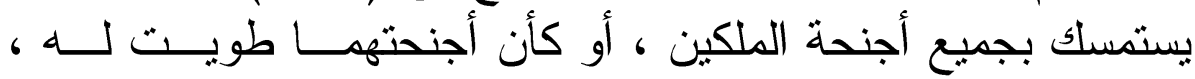

( (1) راجع : الفائق ، و النهاية (هرد) و الورس : شئ أصفر مثل اللطخ يخرج على الرمث

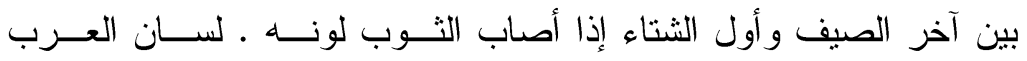

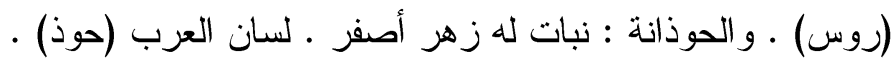




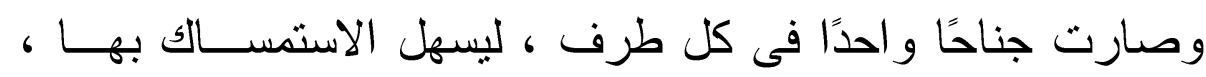

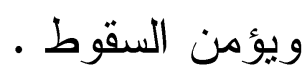

وتأمل روعة اللِيان النبوى فى بناء جملتى الشرط ، و واختبار

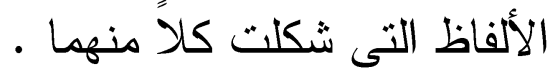

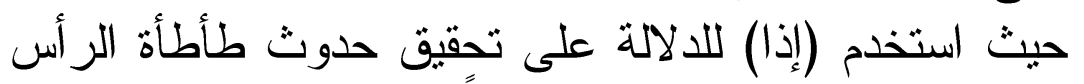

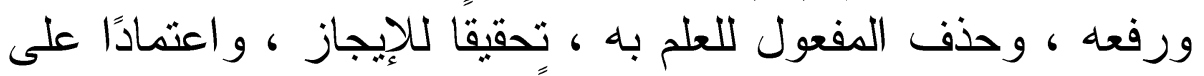

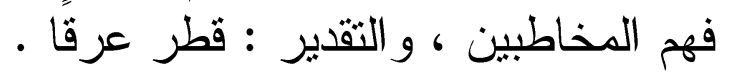

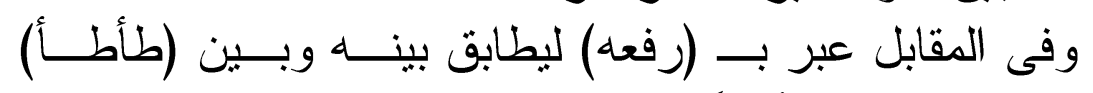

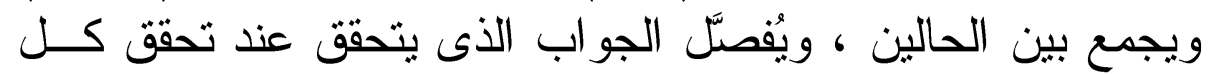

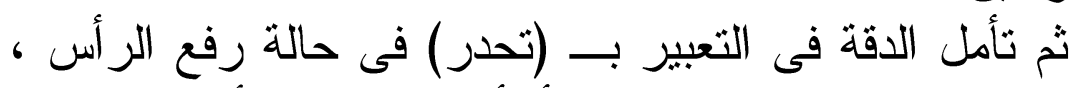

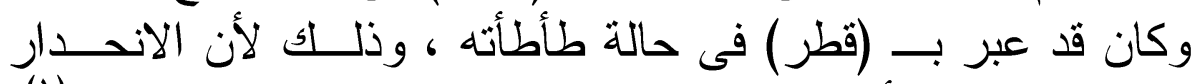

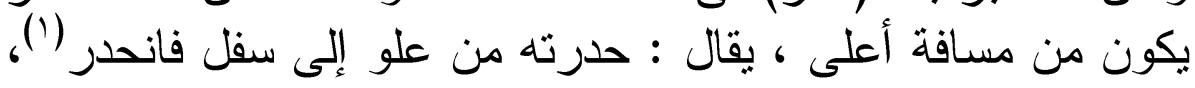

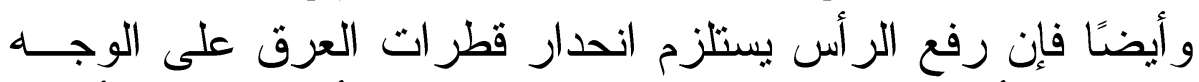

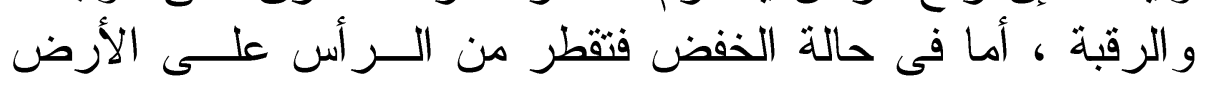

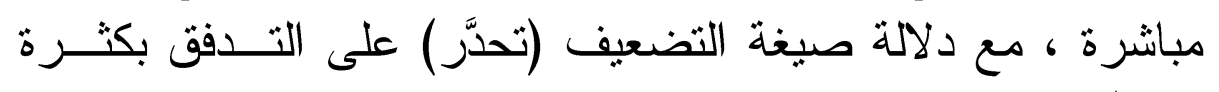

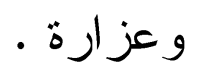

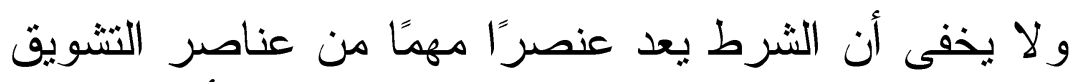

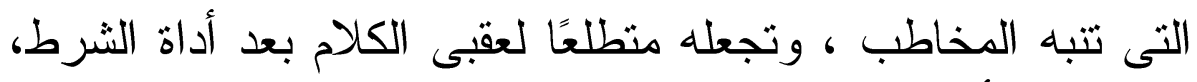

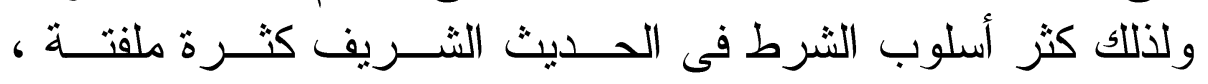

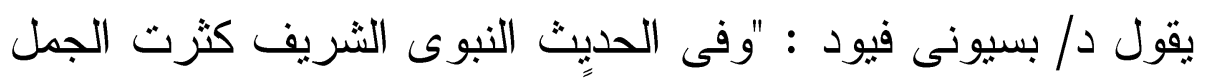

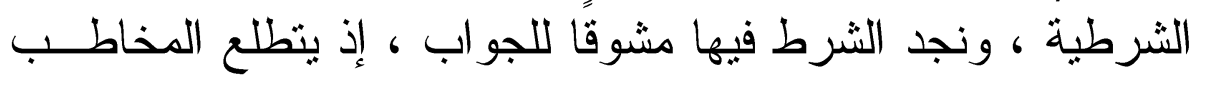

(1) راجع : أساس البلاغة للزمخشرى (حدر) . 


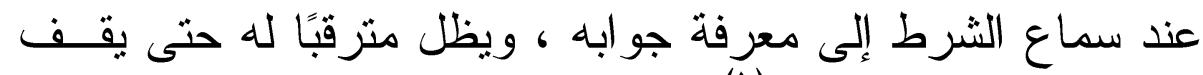
(1) عليه فيتمكن فى ذهنه الفرطه

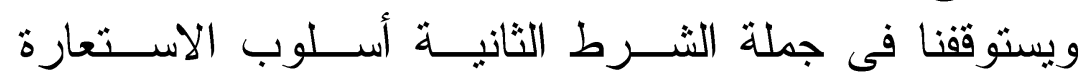

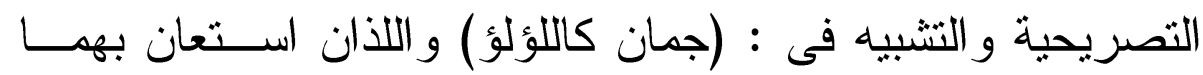

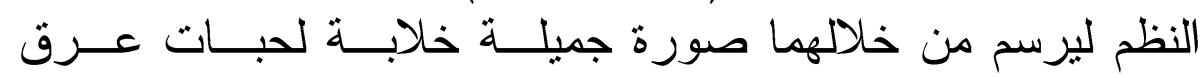

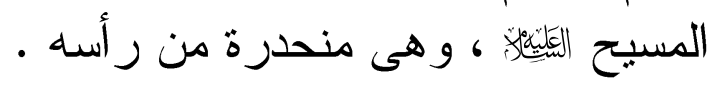

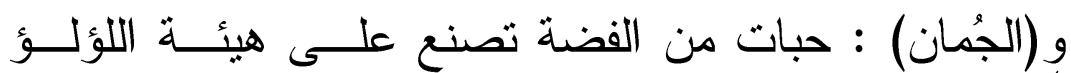

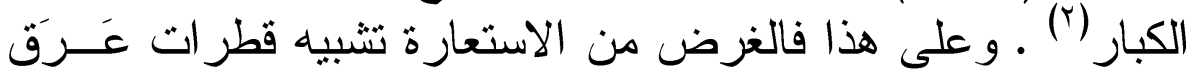

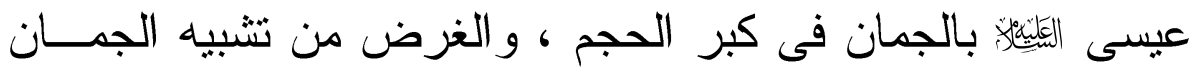

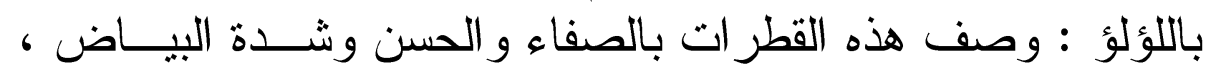

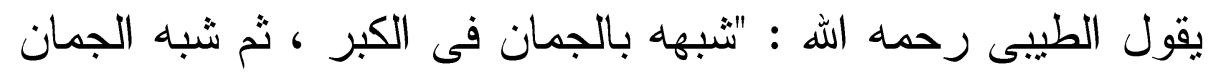

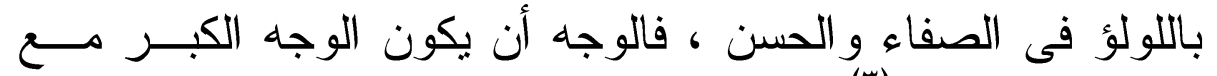

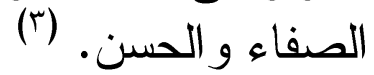

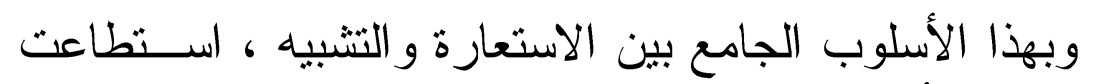

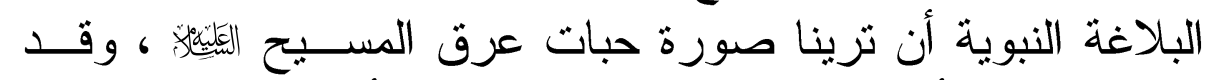

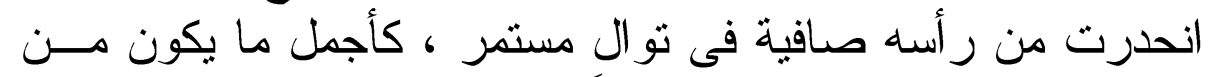

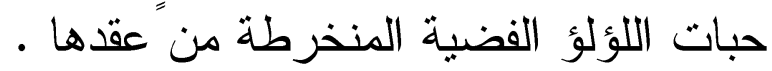

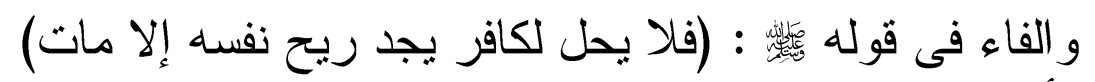

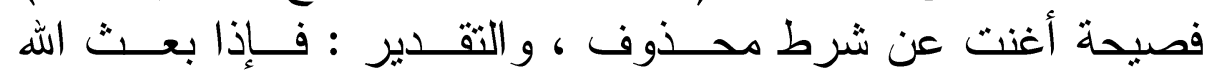

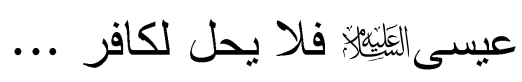

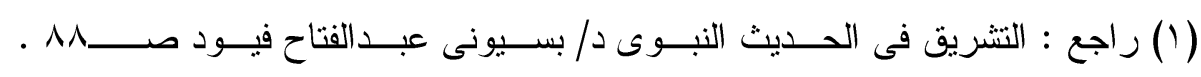

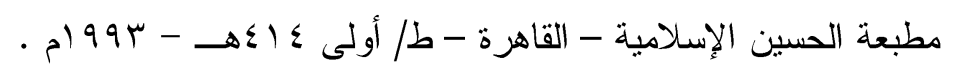

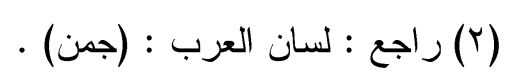

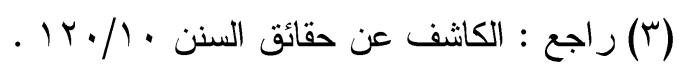




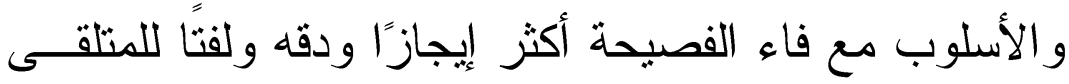

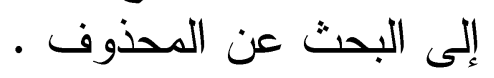

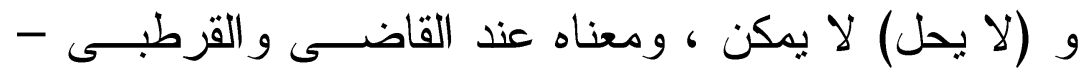

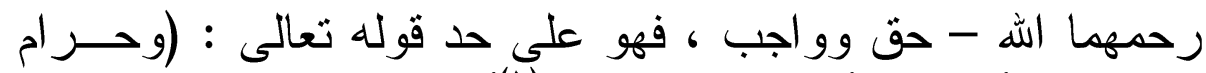

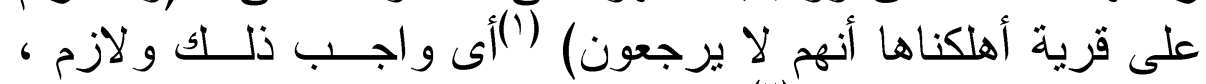

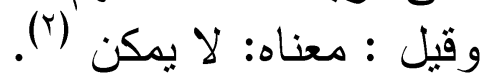

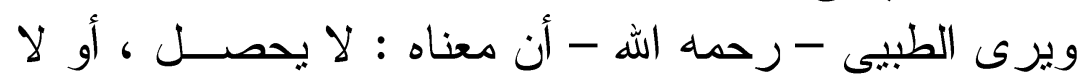

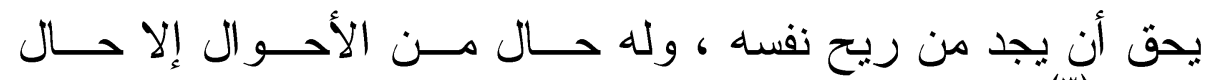

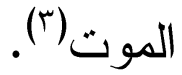

و على هذا فأسلوب القصر فى الجملة الشريفة من باب قصر ،

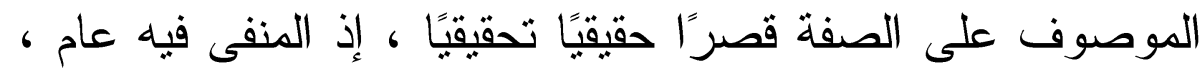

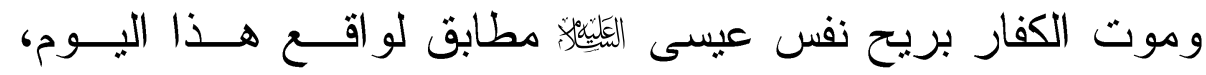

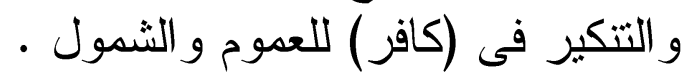

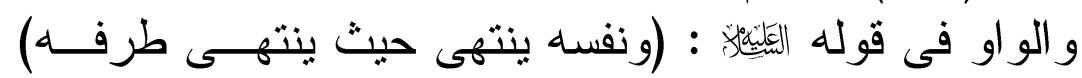
و او الحال ، وجئ بالجملة بعدها لبيان حال انتشار نفس عيسى اليَّلِّنَ)

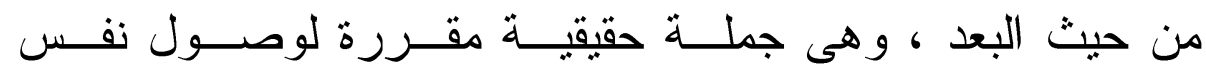

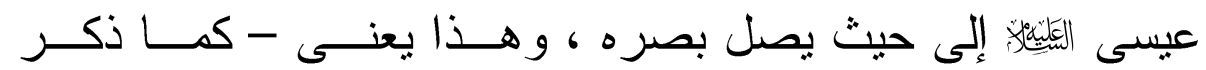

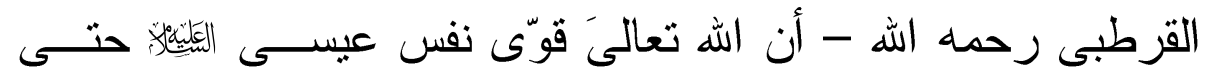

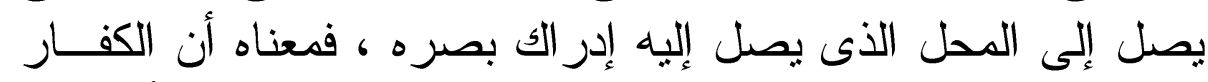

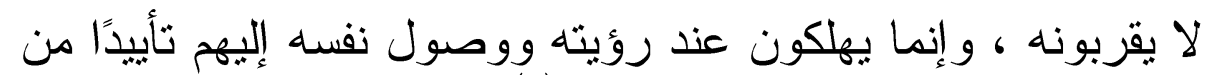

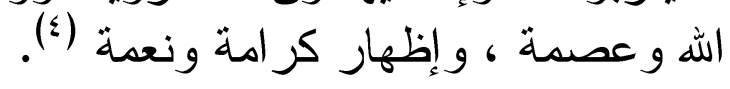

$$
\text { (1) (1) الأنبياء : (1) }
$$

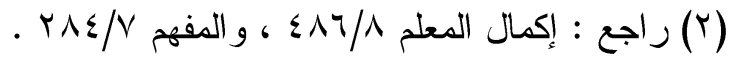

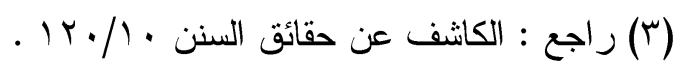

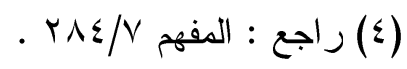


و الفاء فى قوله عليه الصلاة و السلام : (فيطلبه حتى يدركه

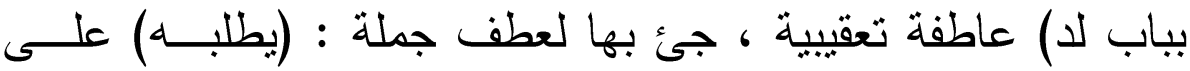

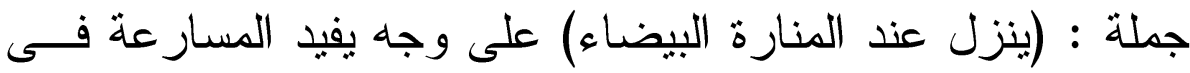

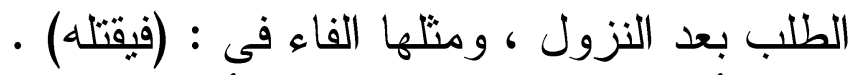

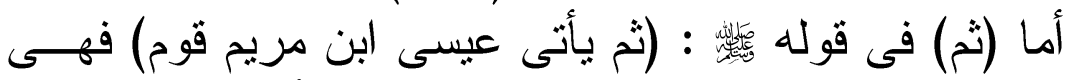

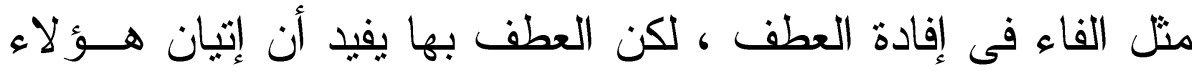

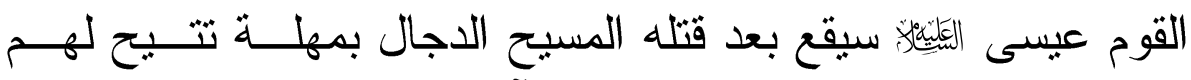

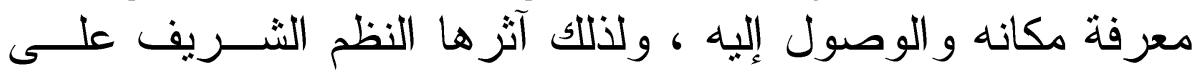
الفاء . معز ومن بلاغة النظم النبوى فى هذه الجملة أن قــدم المفعــول

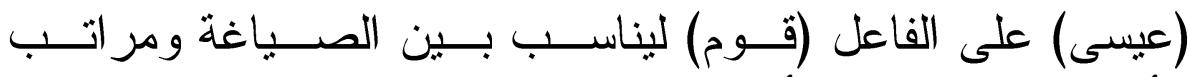

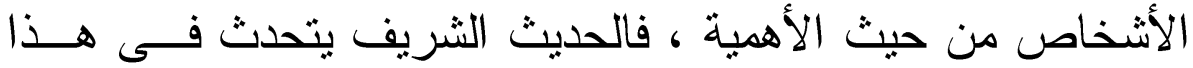

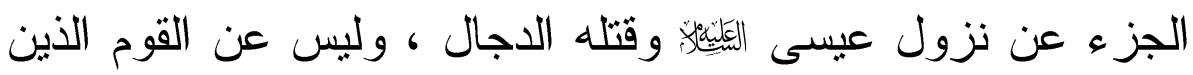

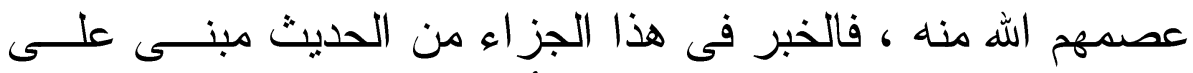

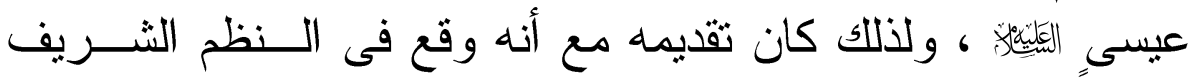

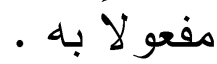
وللك أن تتخيل ما أداه التتكير فى (قوم) من تعظيم وتقخــيم

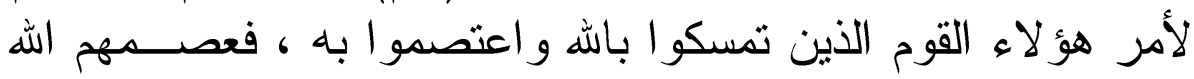

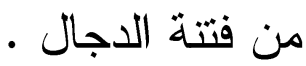

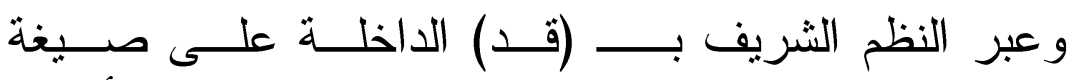

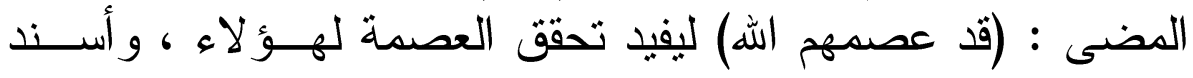

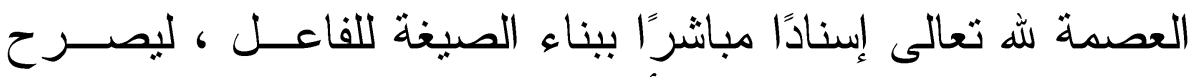

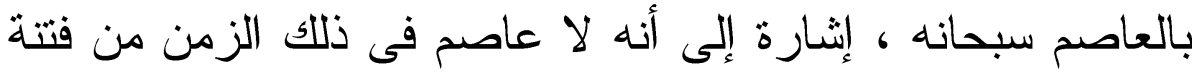

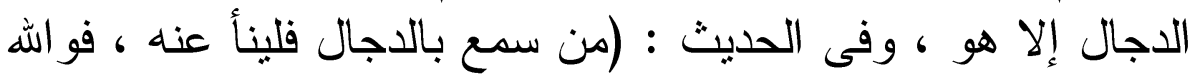


إن الرجل ليأتيه ، وهو يحسب أنه مؤمن فيتبعه مما يبعث به مــن

الشبهات) (')

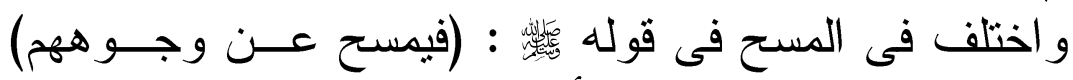

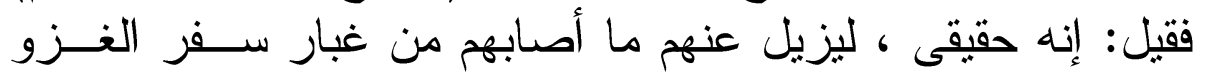

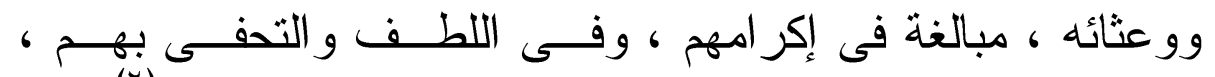

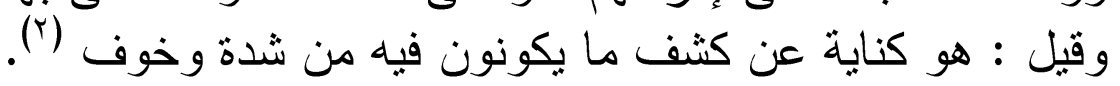

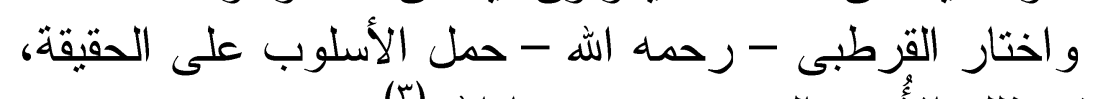

وتبعه فى ذلك الأبى و السنوسى رحمهما الله (r).

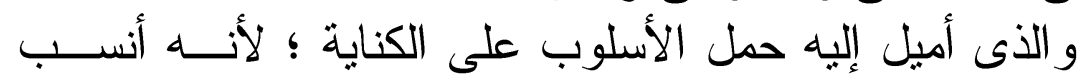

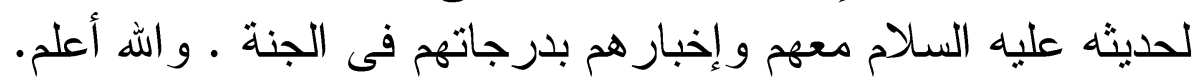

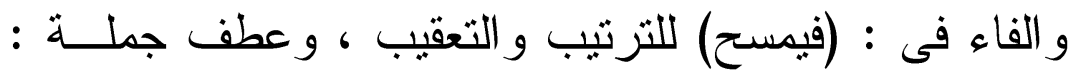

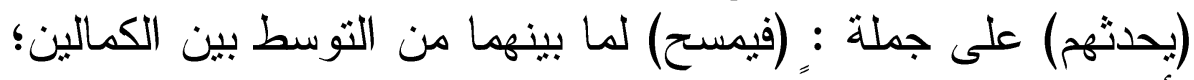

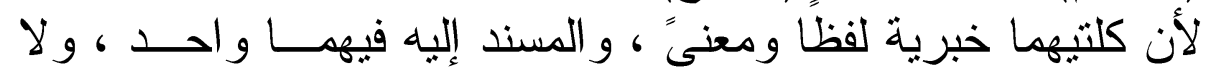

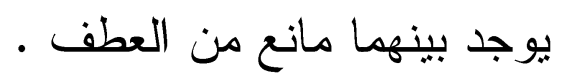

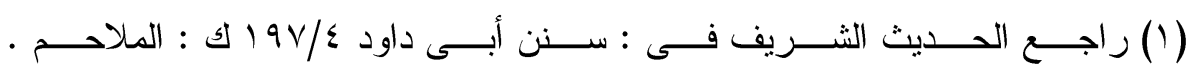

ب: خروج الدجال - نشر : دار الكتاب العربى - بيروت - بدون تاريخ -

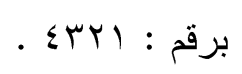

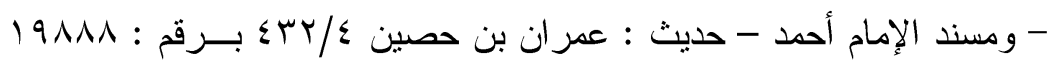

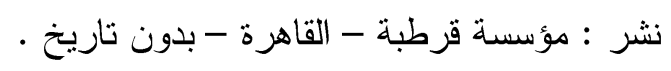

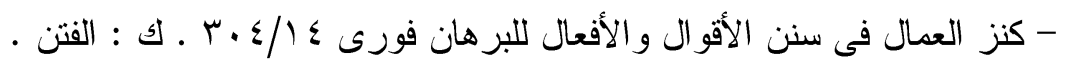

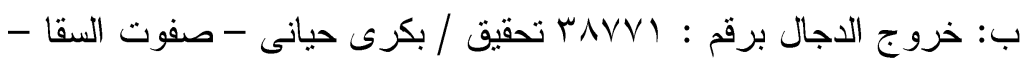

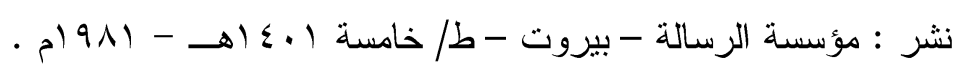

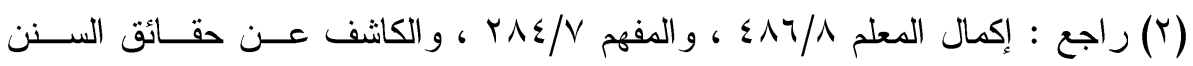

$$
.141 / \text {. }
$$

(ז) راجع : إكمال إكمال المعلم ، ومكمل إكمال الإكمال 9/.. .؟ . 
ومن بلاغة النظم النبوى فى هذا المقام أن عبــر بالتحــديث.

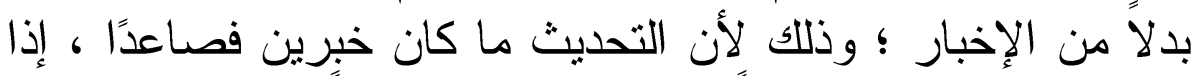

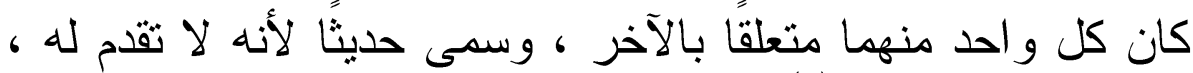

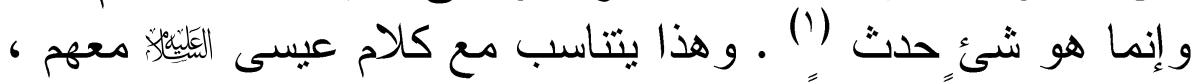

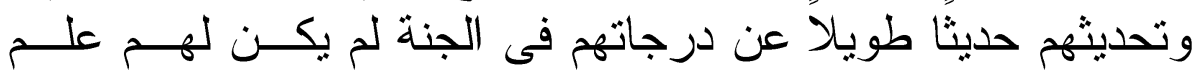

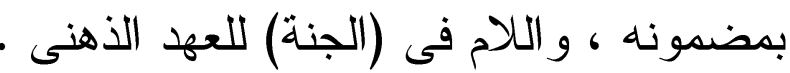

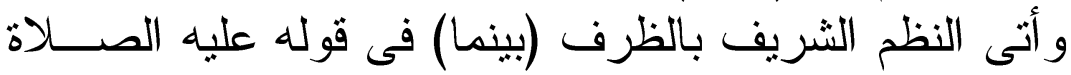
و السلام : (فيينما هو كذلك إذ أوحى الله إلى عيسى) ليشير إلـى أن أن إنى وحى الله إلى عيسى بخبر هؤلاء العباد كان أثناء مسحه على وجوه

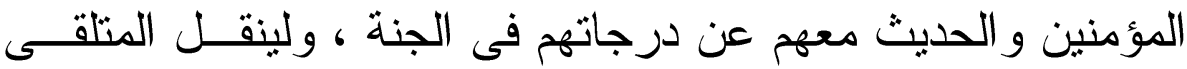

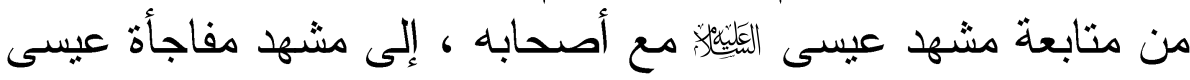

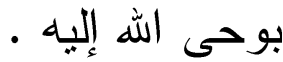
وتأمل مناسبة التعبير بالاسم الظاهر بـــلاً مــن الضـــير

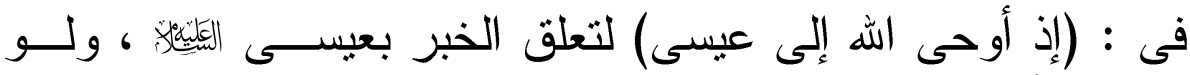

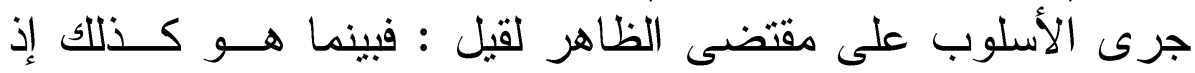
أوحى الله إلبه . الإنوى

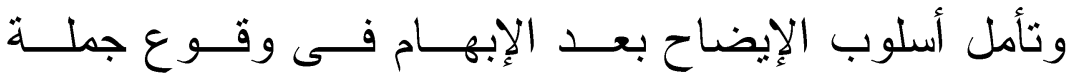

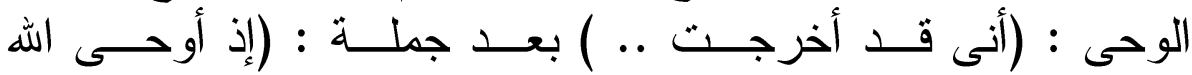

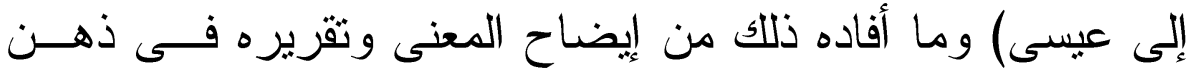

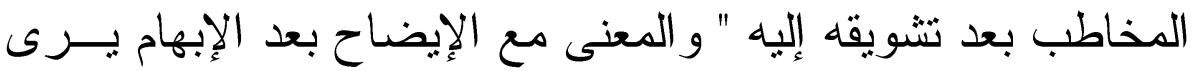

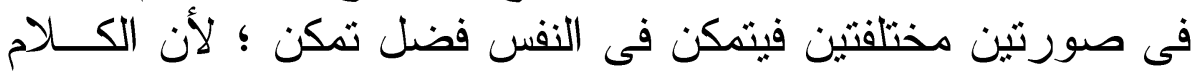

(1) راجع : الفروق اللغوية لأبى هلال العسكرى صــاس تحقيق/ عماد زكى البارون نشر : المكتبة التوفيقية - القاهرة - بدون تاريخ. 
إذا قرع السمع على جهة الإبهام ذهب السامع فيه كل مذهب ، وفي ، فإذا وضح تمكن فى النفس فضل تمكن ، وكان شعور ها به أتم" ( ().

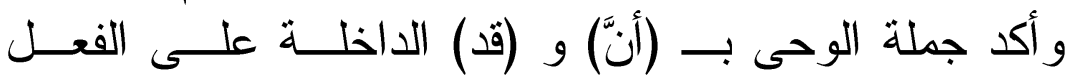

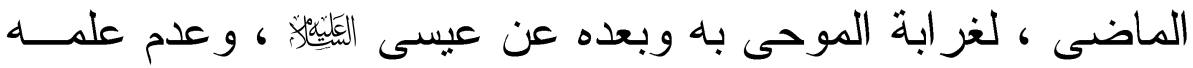

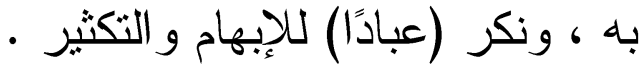

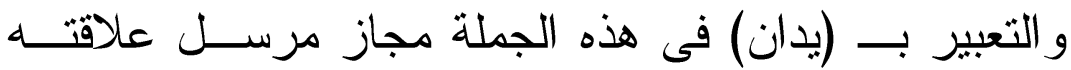

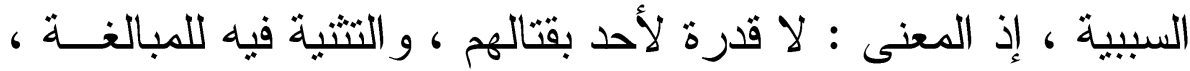

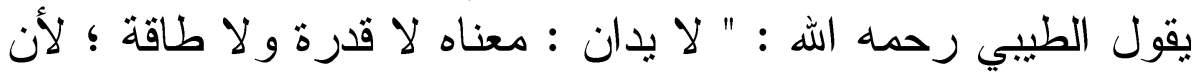

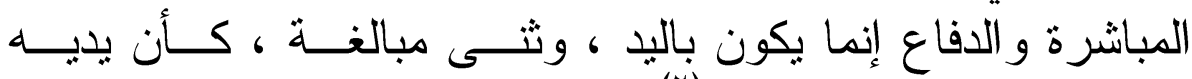

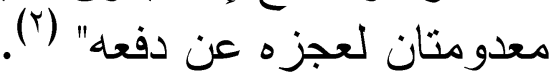

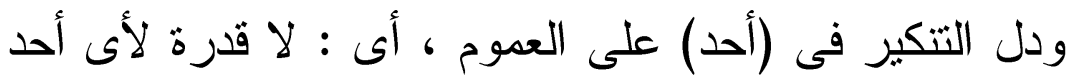

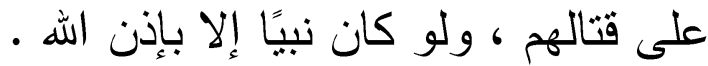

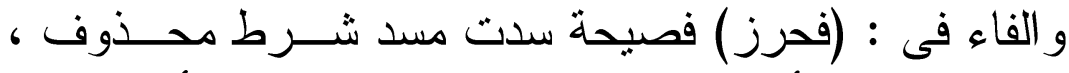

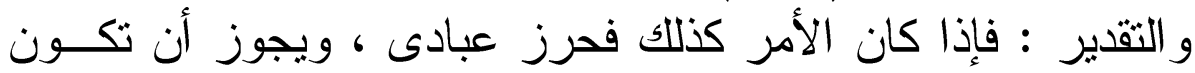

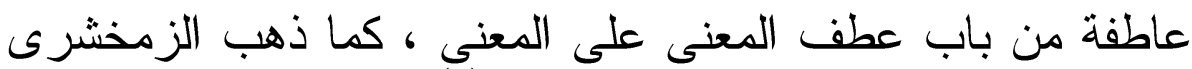

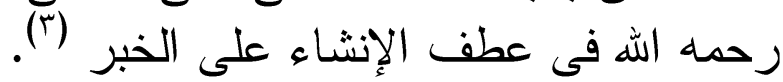

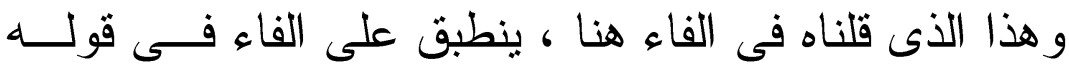

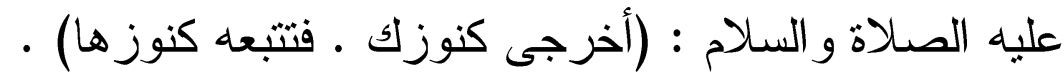

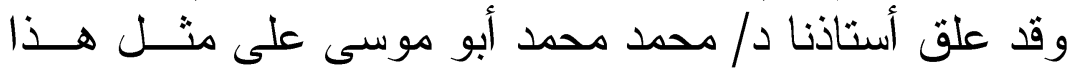

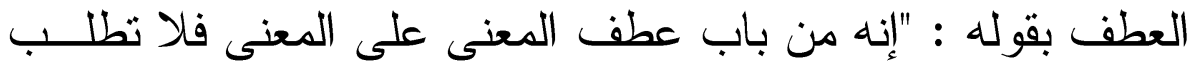

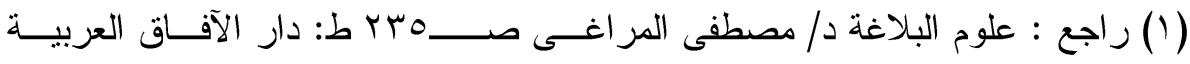

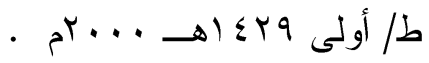

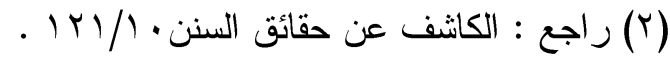

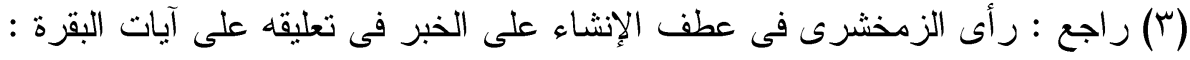

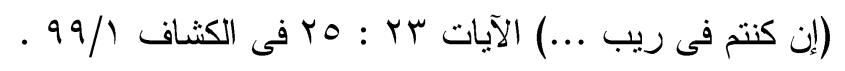


فيه المشاكلة بين المعطوف و المعطوف عليه ، وفى هذه الفاء دعنى الترتيب ، ومعنى السببية" (1) و الأمر فى (حرز) باق على حقيقته ، و اجب التبفيذ للنجـــاة

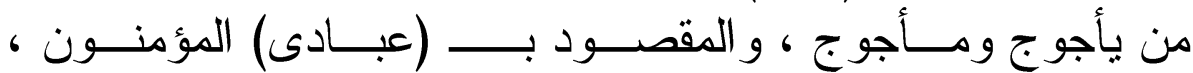

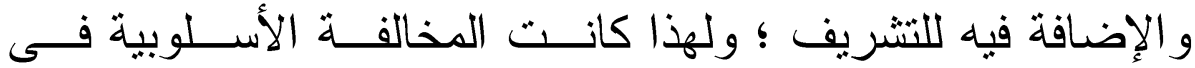

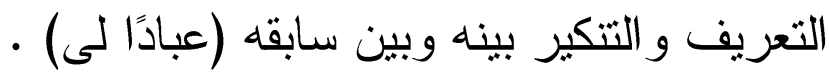

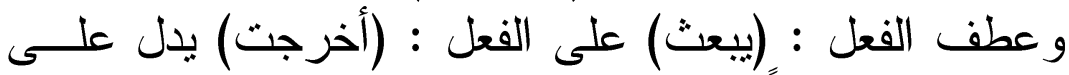

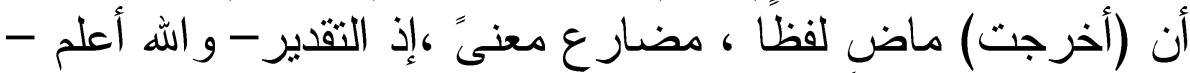

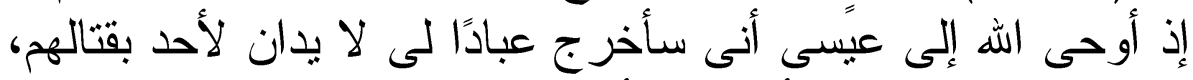

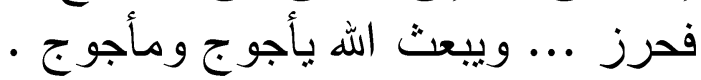

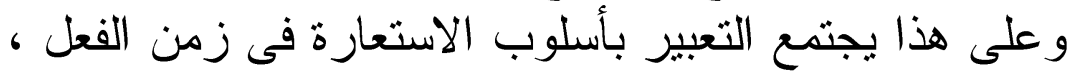

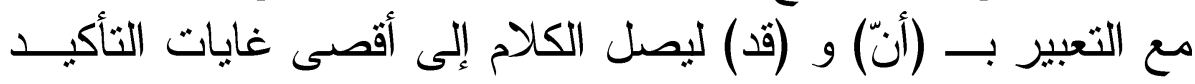
و التحقيق.

وفى الكلام إيجاز بالحذف ، و المحذوف هنا جملة كاملــة ،

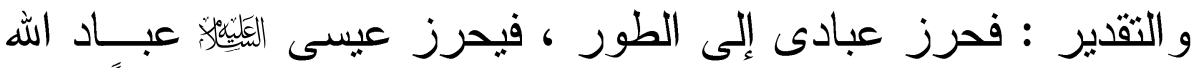

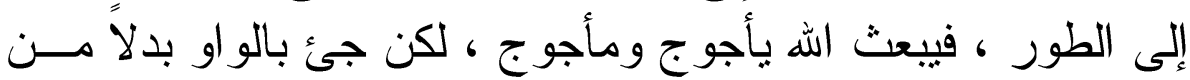

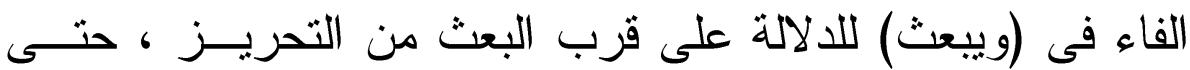

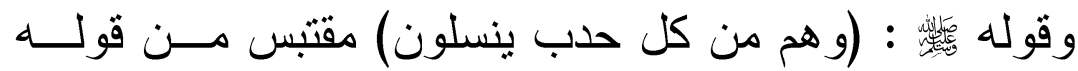

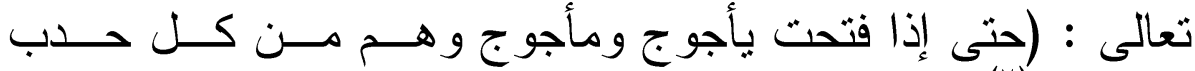

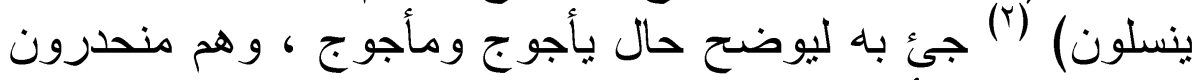

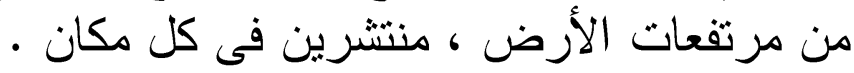

(1) راجع : شرح أحاديث من صحيح البخارى ، صــr"1 . 97 : 97 : (r) الأنبياء 


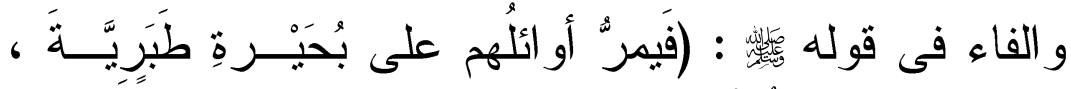

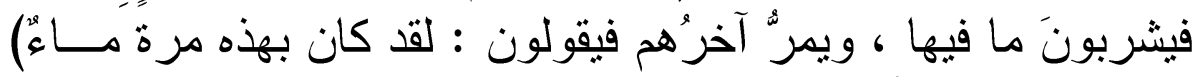

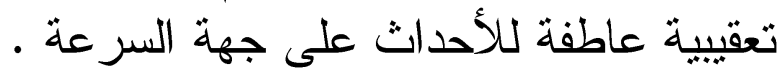

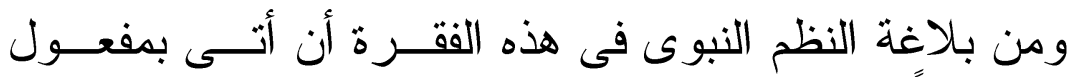

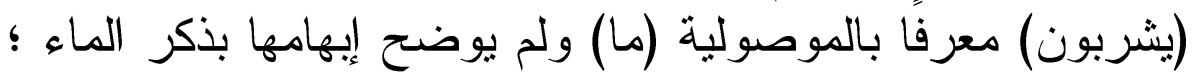

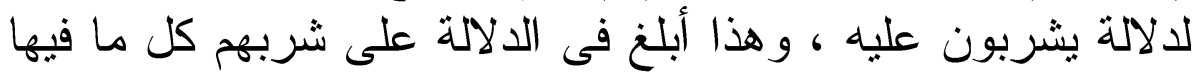

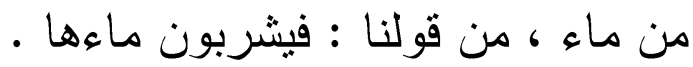

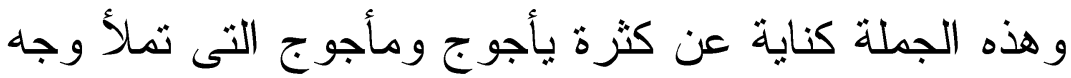

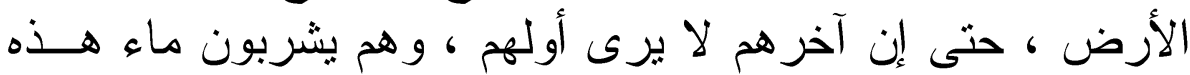

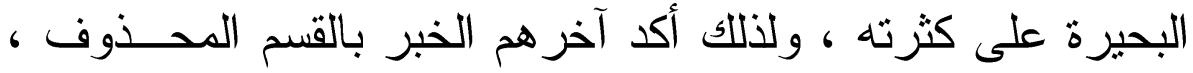

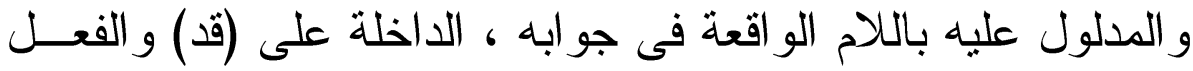

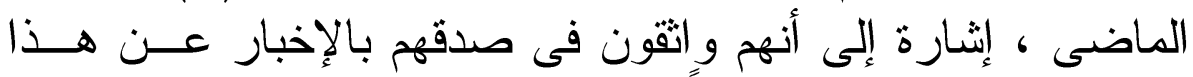

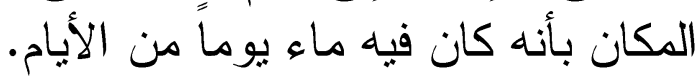

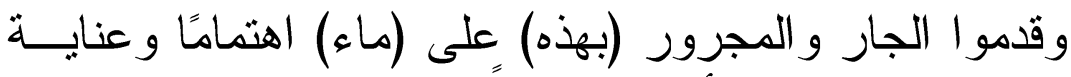

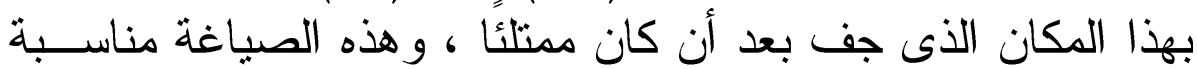

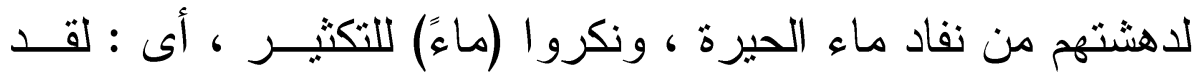

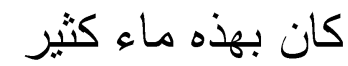
و عطف النظم الشريف جملة : (يمر آخرهم) على جملـــة :

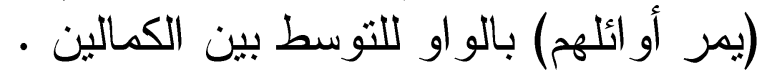

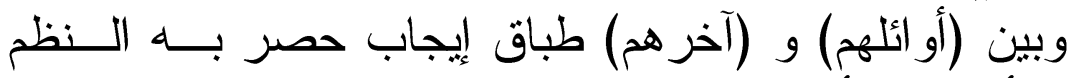

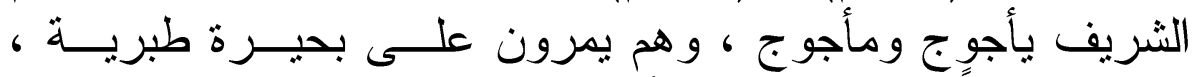

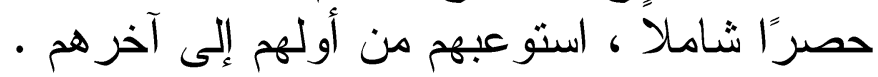
ومن بلاغة النظم النبوى فى هذه الفقرة أن أن جمع : أو أوائلهم)

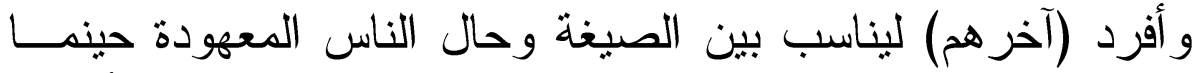
يتواردون إلى الماء ويتدافعون إليه ، فيكون المتقدمون منهم أكثــر من المتأخرين المين 


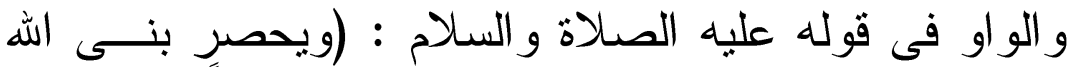

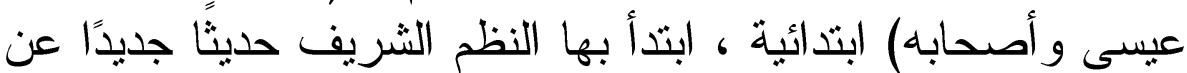

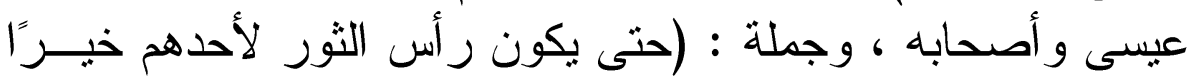

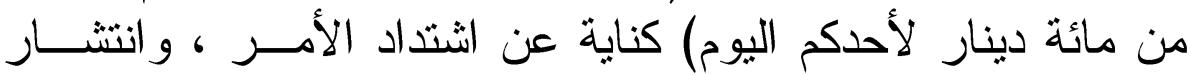

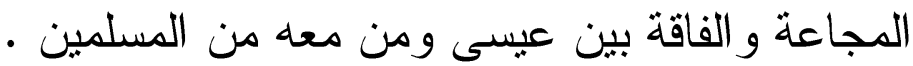

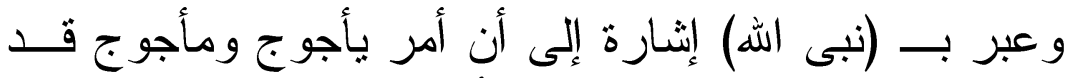

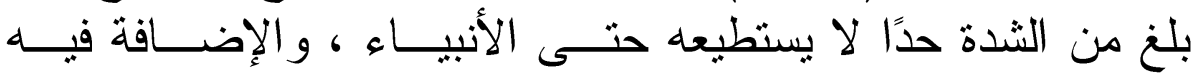
للتشريف دن

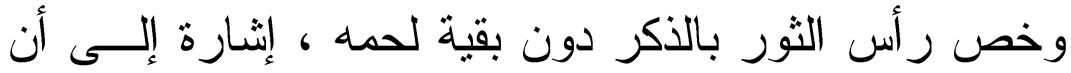

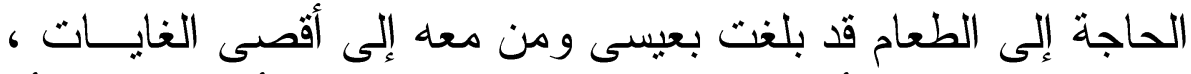

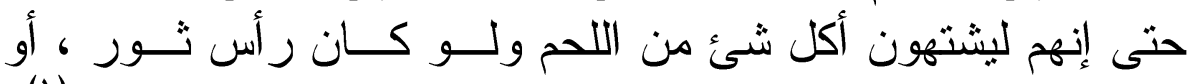

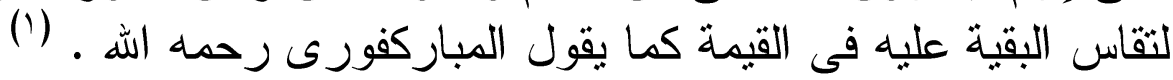

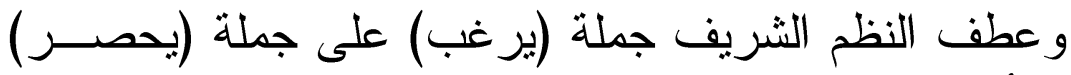

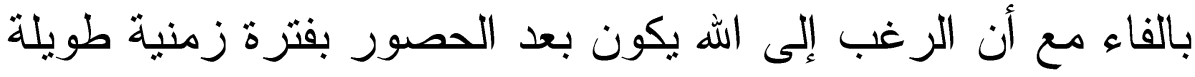

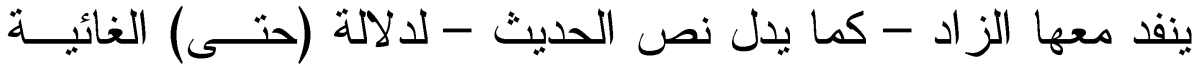

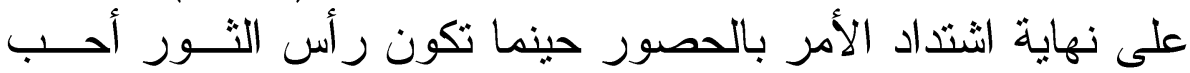

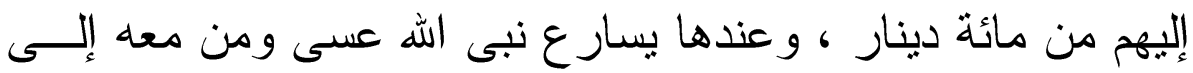

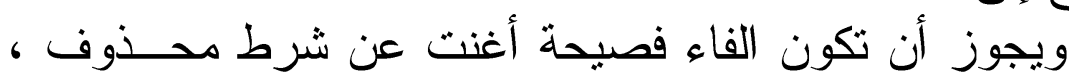
التضر ع إلى الله من دئائل

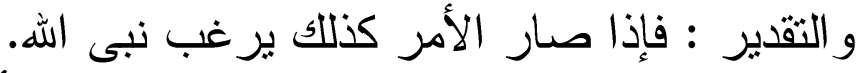

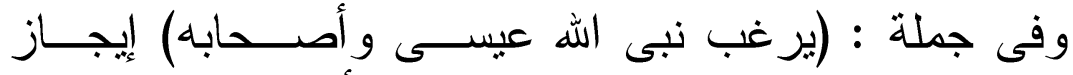

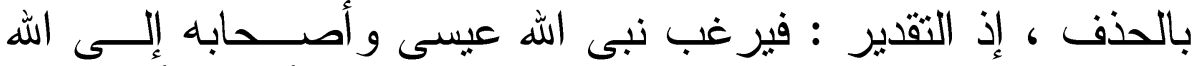

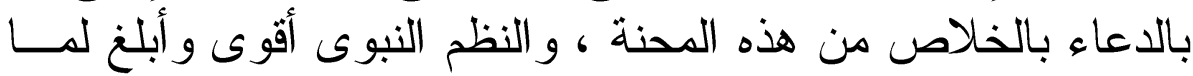

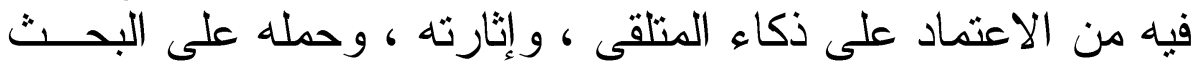


عن الجزء المفقود من الجملة ، فإذا ما وقف عليه حصلت المتعــة و النشوة .

ثم ثأنى استجابة الله تعالى لنبيه عيسى و المؤمنين : (فيرسل

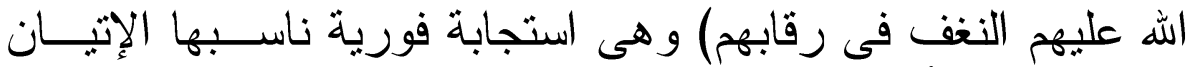

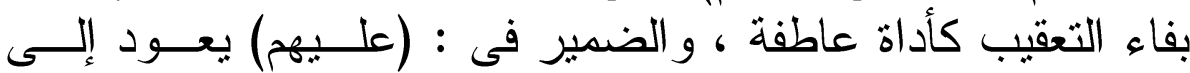

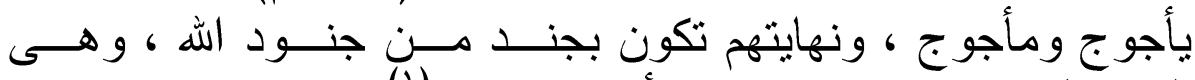

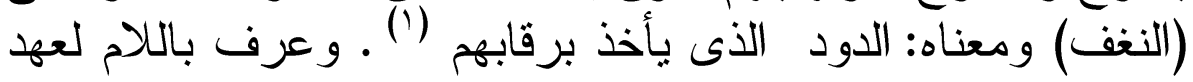

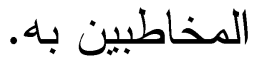

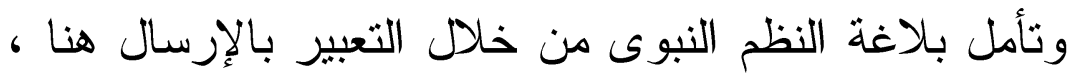

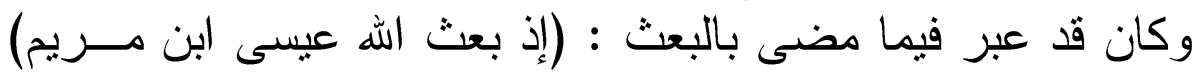

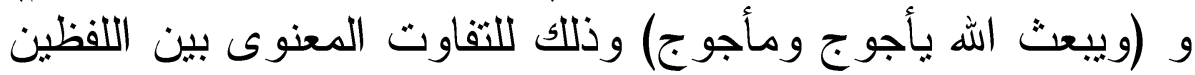

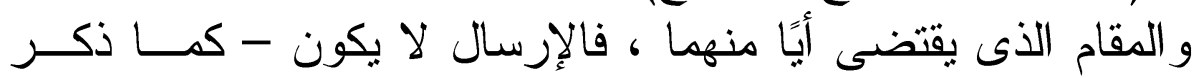

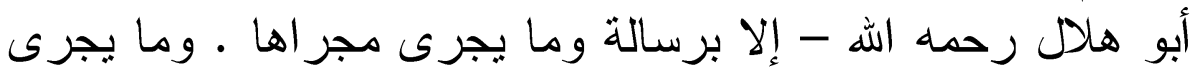

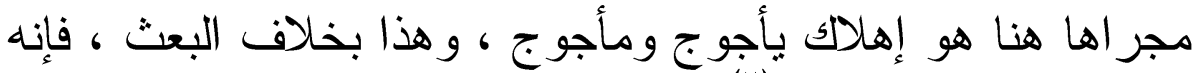

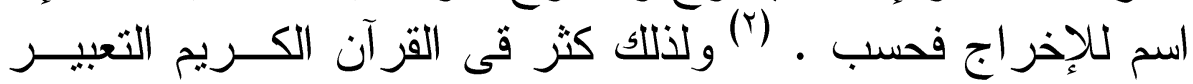

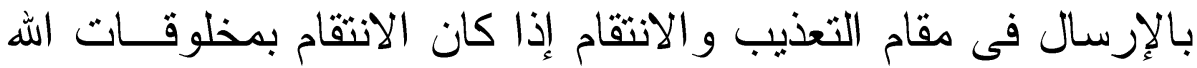

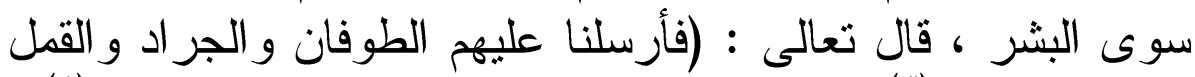

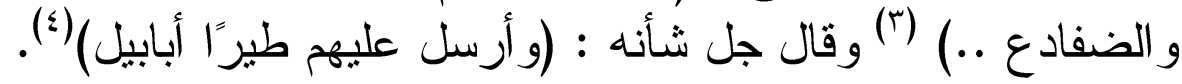

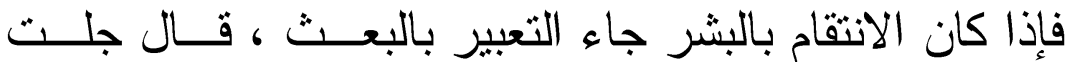

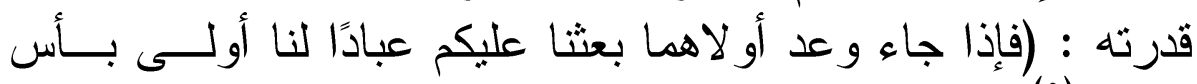

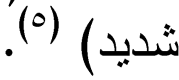

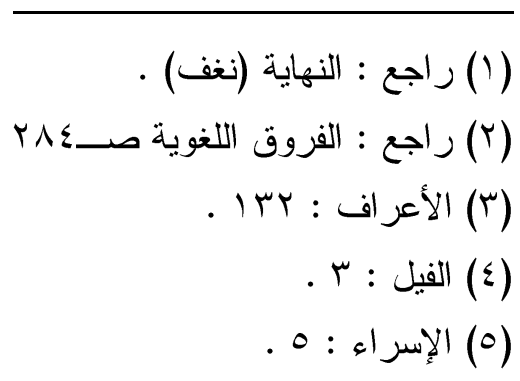




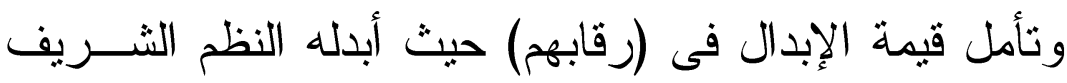

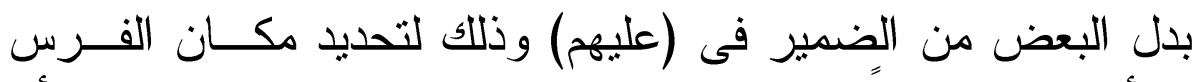

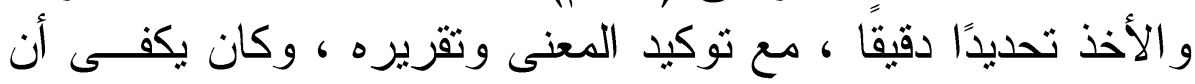

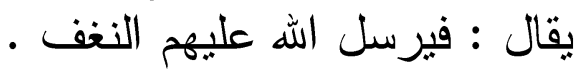

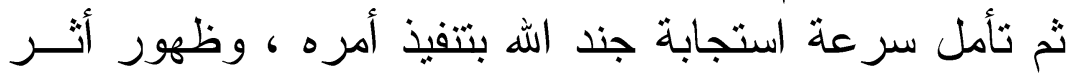

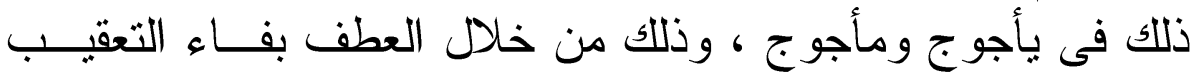

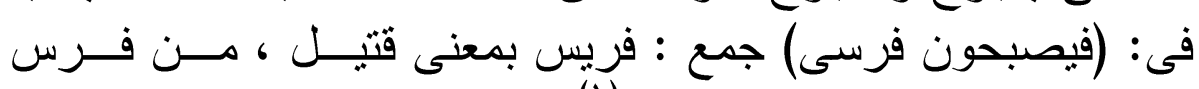

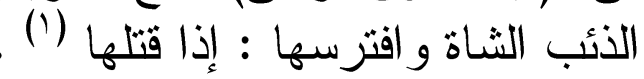

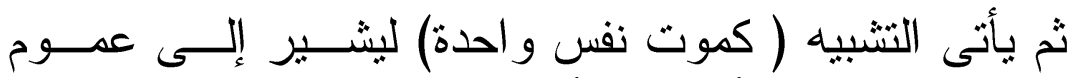

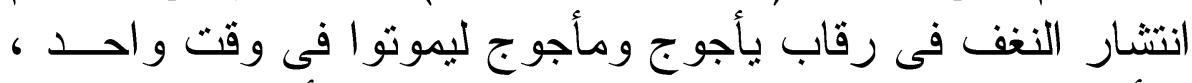

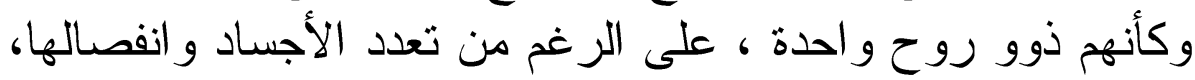

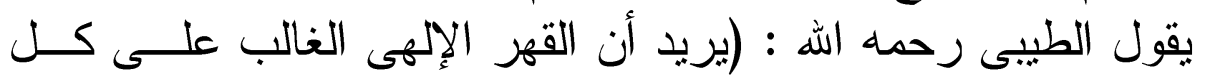

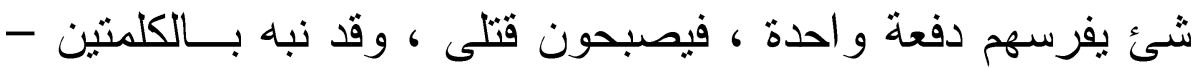

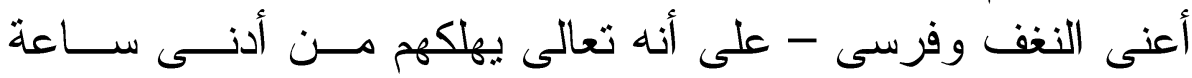

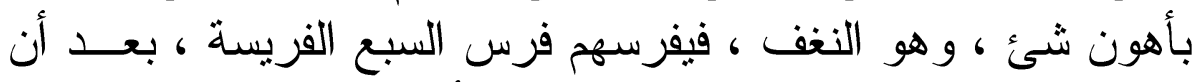

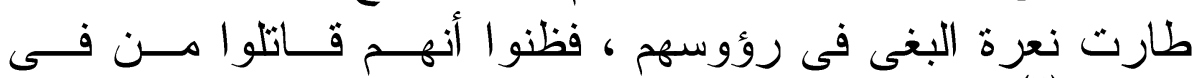

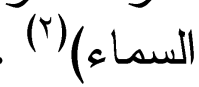
هذا وقد دل التتكير فى (نفس) على الإفراد ، و أكــدت هــذه

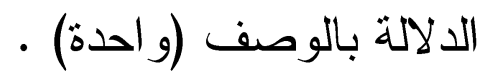

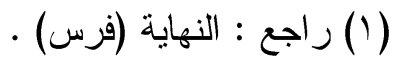

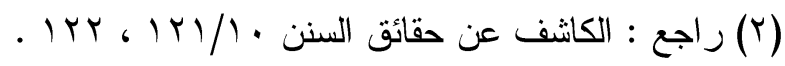




\section{إلى الأرض البك وأصحابه}

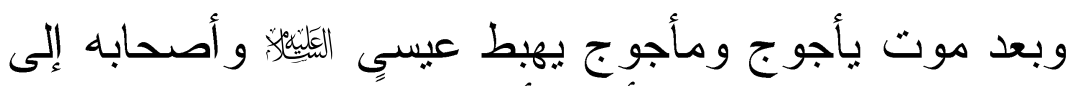

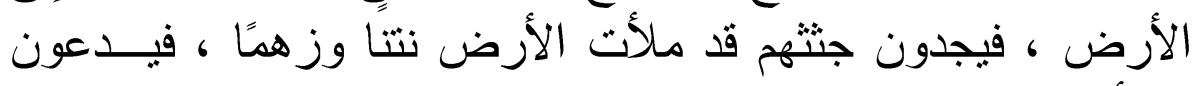

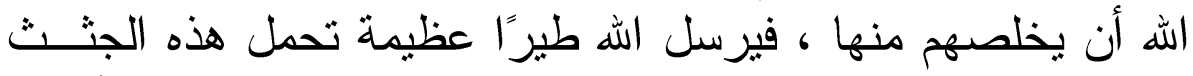

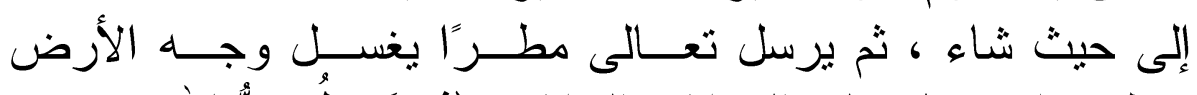

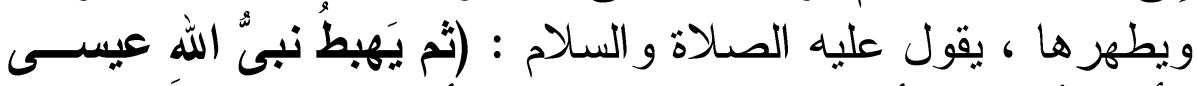

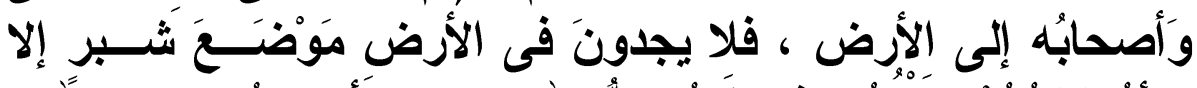

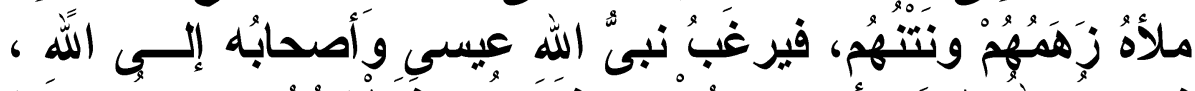

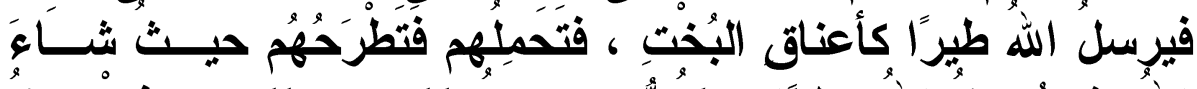

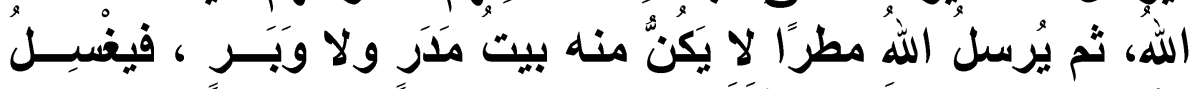

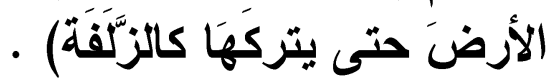

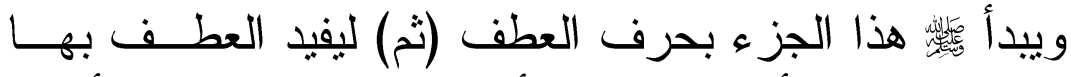

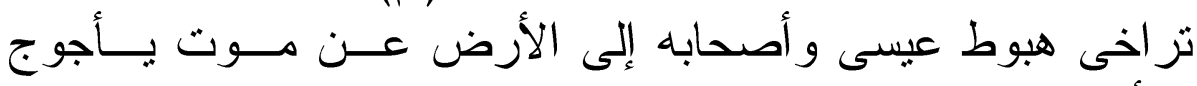

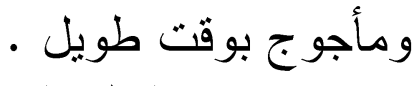

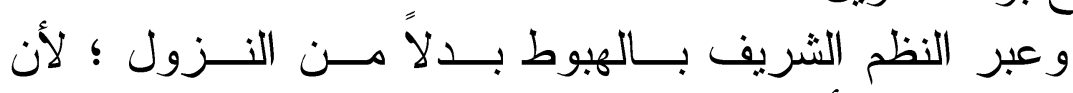

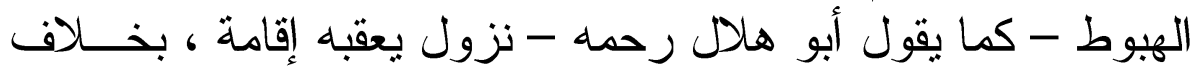

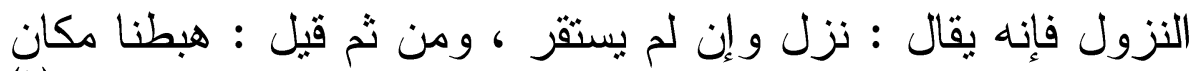

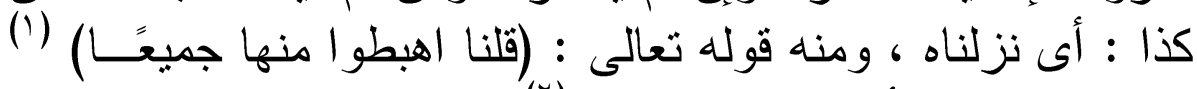

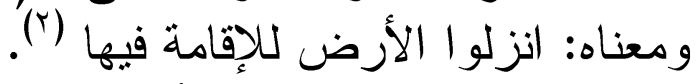

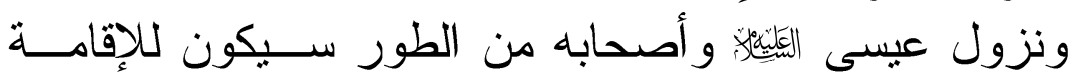

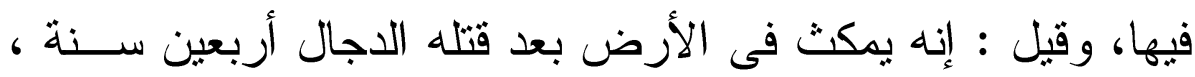


ثم يموت ويصلى عليه المسلمون ('). ومن ثم آثز النظم الثـــريف التعبير بالهيوط دون النزول أو غيره مما يدل على على معناه.

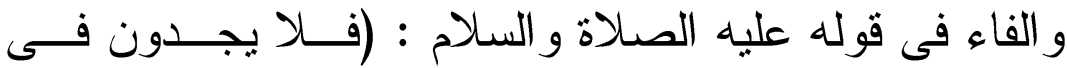

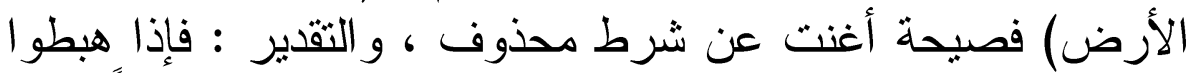

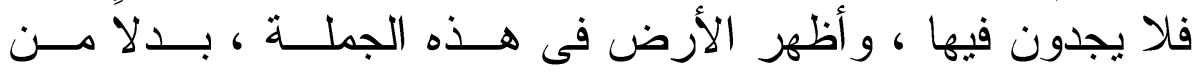

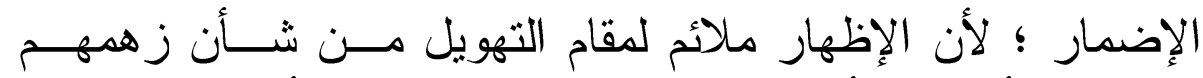

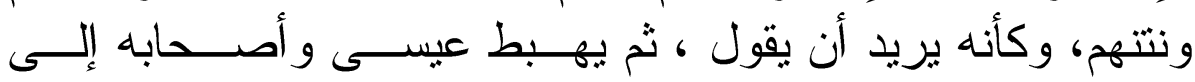

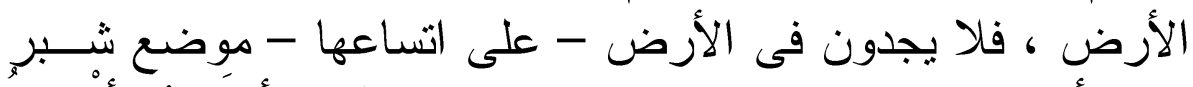

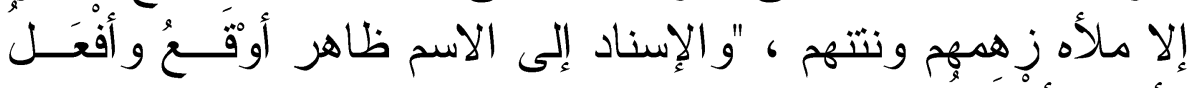

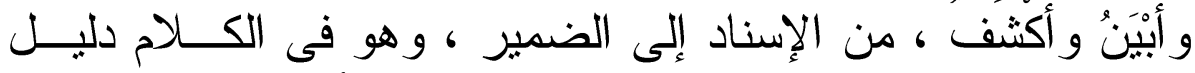

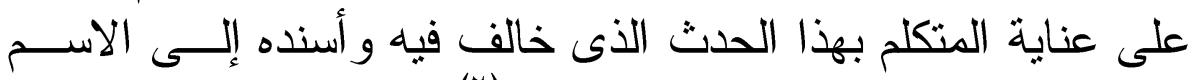

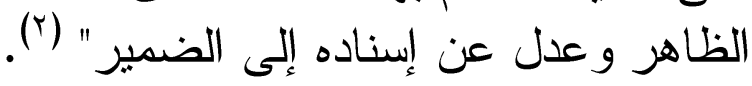

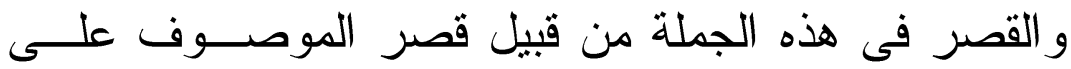

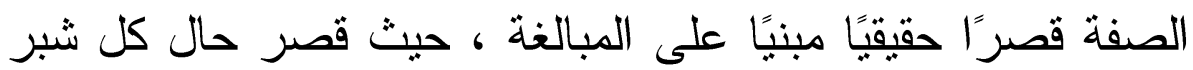

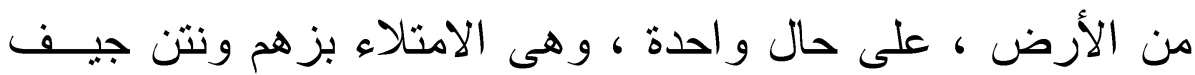

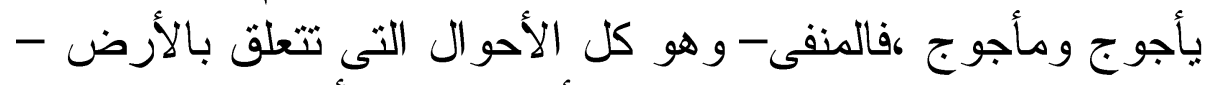

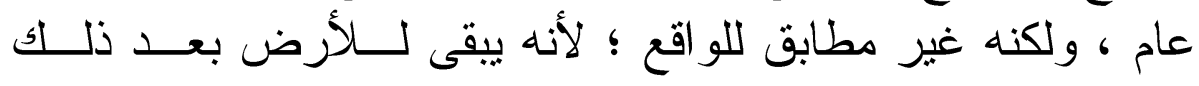

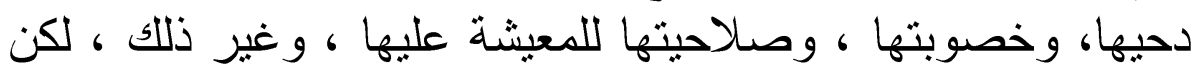

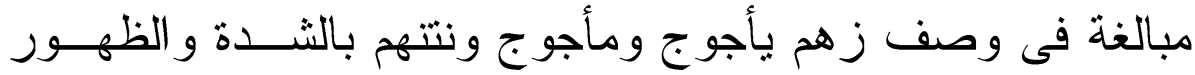

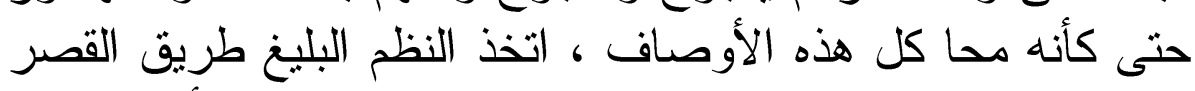

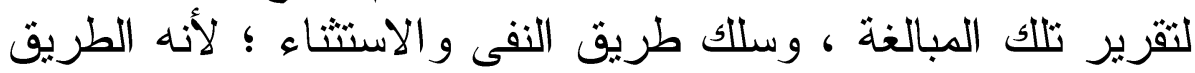

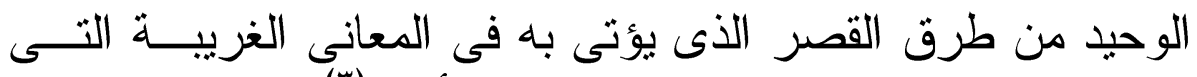
تحتاج فى إثباتها إلى مزيد من التقرير و التأكيد (؟).

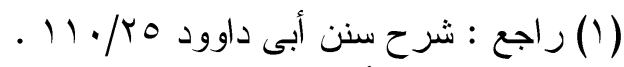

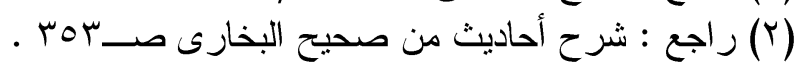

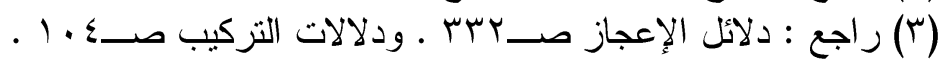




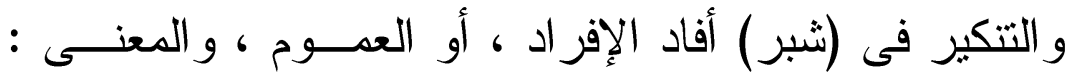

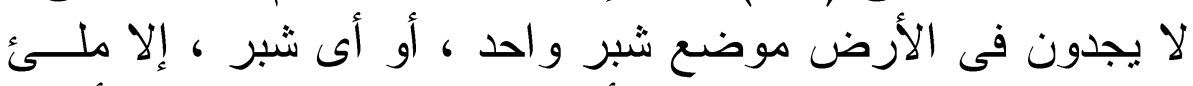

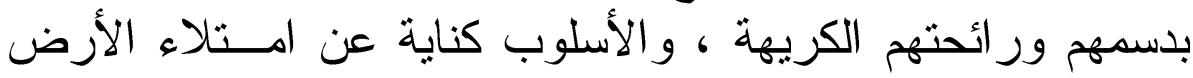

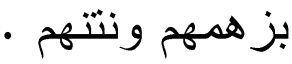

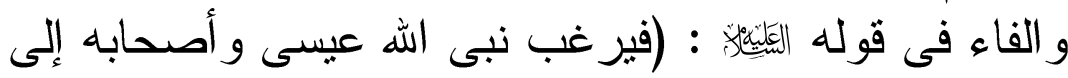

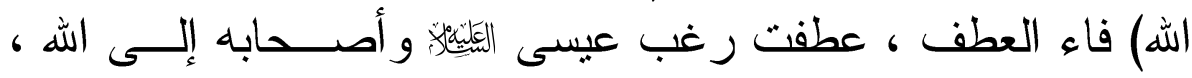

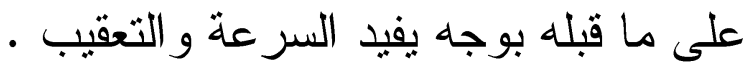

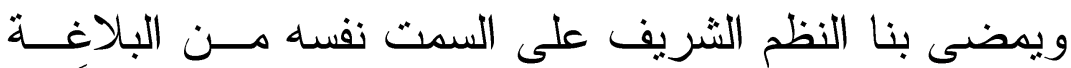

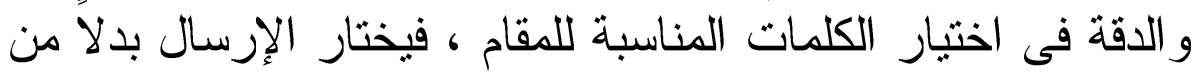

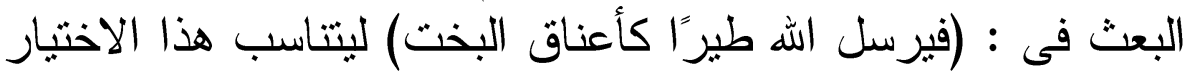

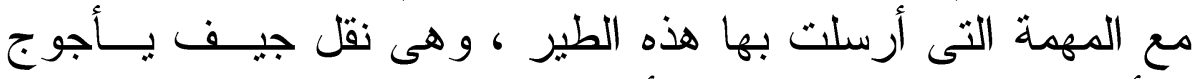

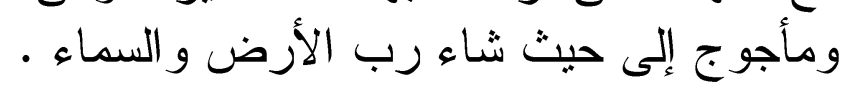

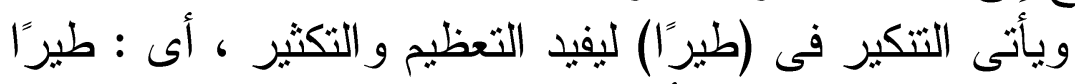

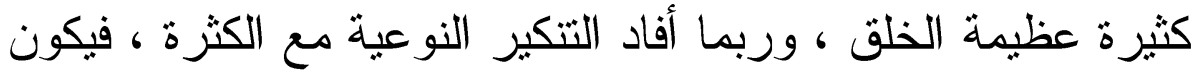

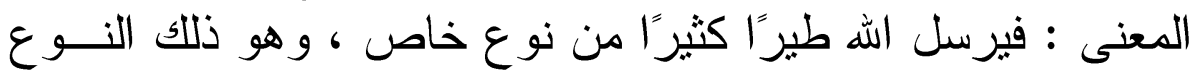

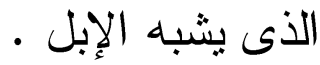

و (البخت) إبل طو ال الأعناق (') ـ فتشبيه الطير بها يلحقهــا

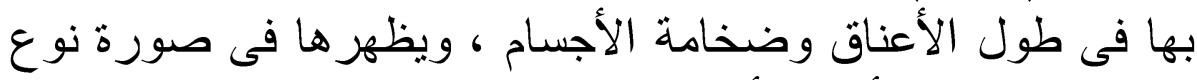

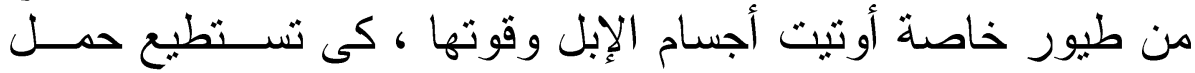

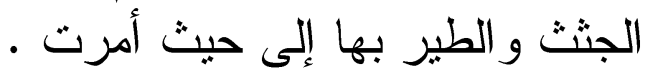

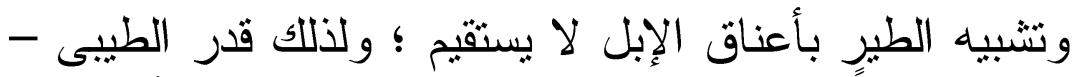

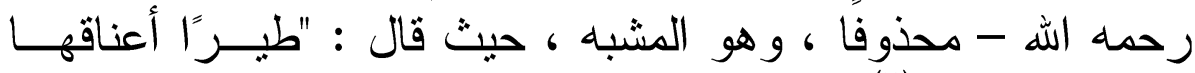

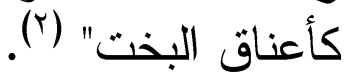

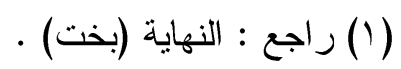

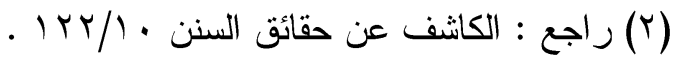




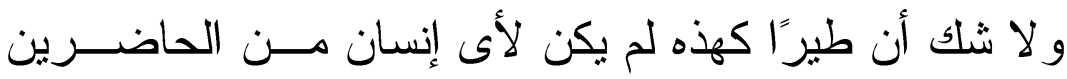

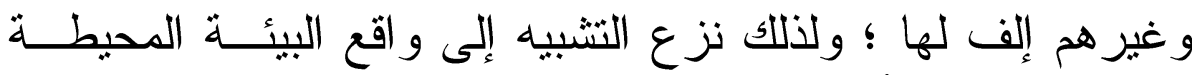

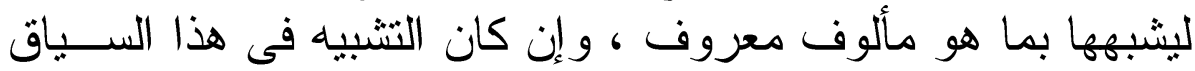

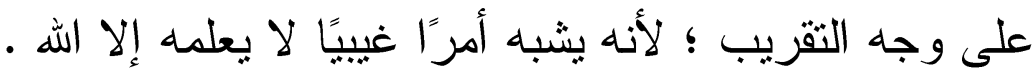

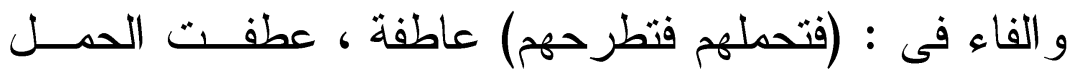

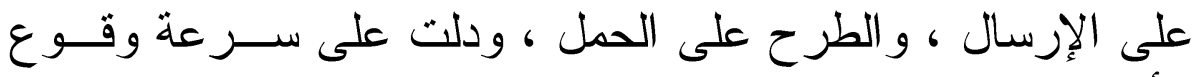

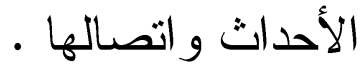
وتأمل موقع (ثم) فى قوله له

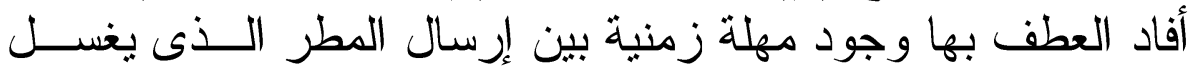

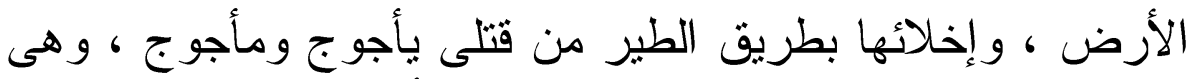

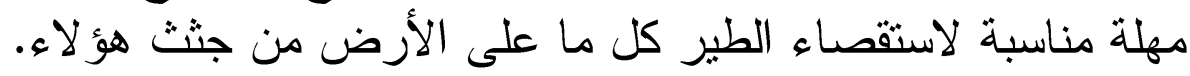

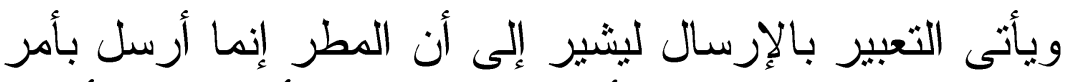

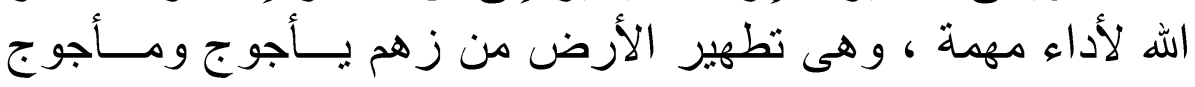
ونتنهم. ثم يأنى التنكير فى (مطر) ليوحى بالكثرة و الغز ارة ، مدـــا

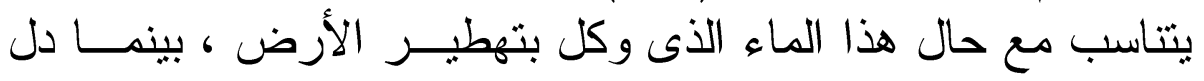

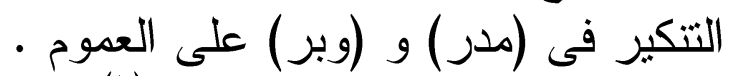

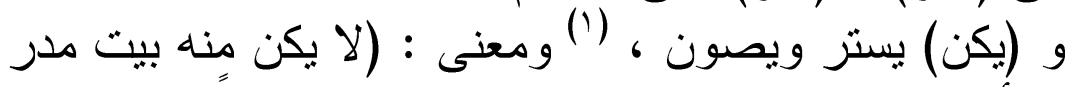

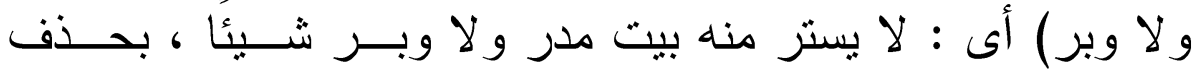

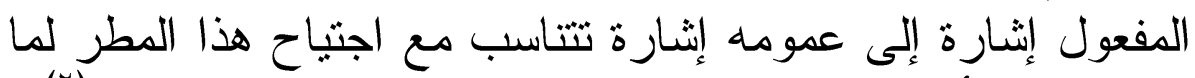

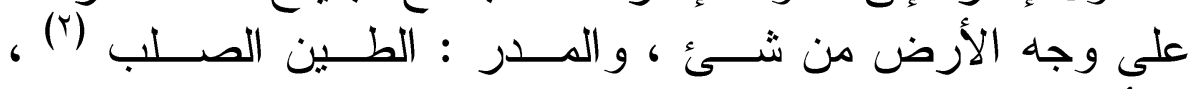

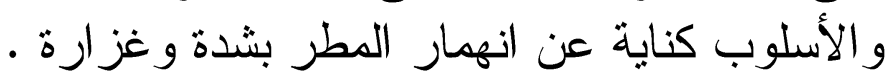




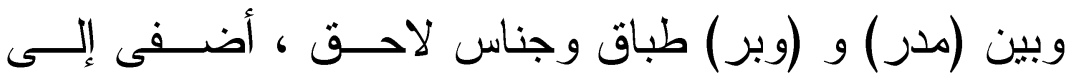

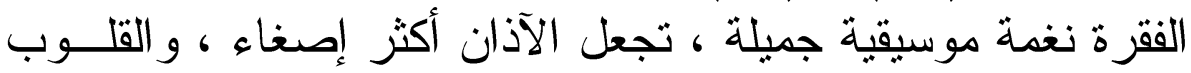

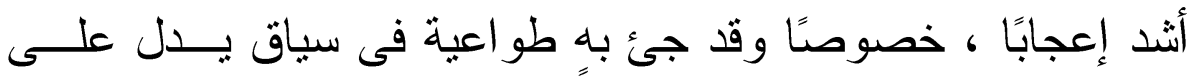

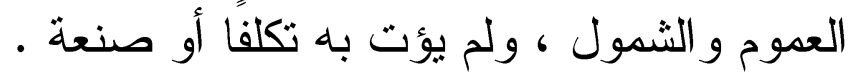

و الطباق و الجناس وسائر المحسناث البديعية إذا جاءت وكؤه وكذا

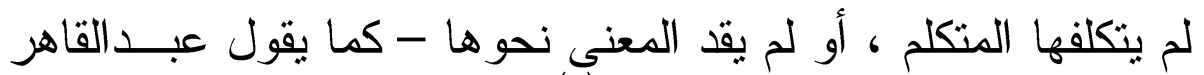
رحمه الله - كانت حسنة محمودة (1).

و المتأمل فى هذه الفقرة يجد فيها ذكر لفظ الجلالة بطريــق هُه وضع المظهر موضع المضدر أربع مرات ، إذ لو جرى الأسلوب

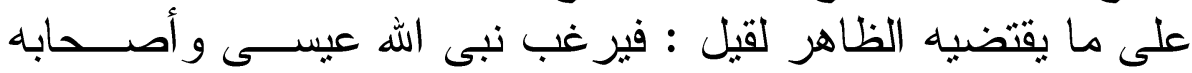

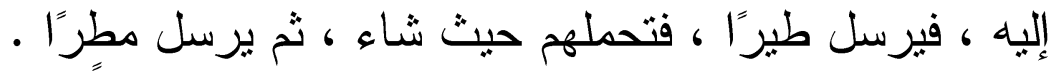

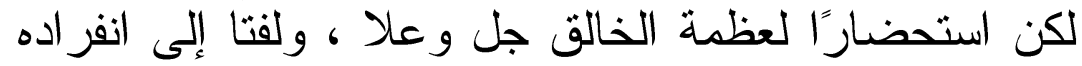

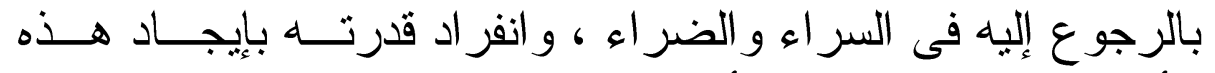

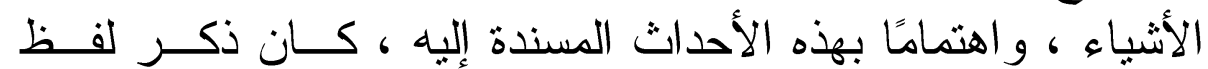

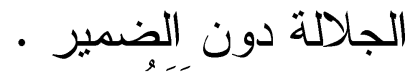

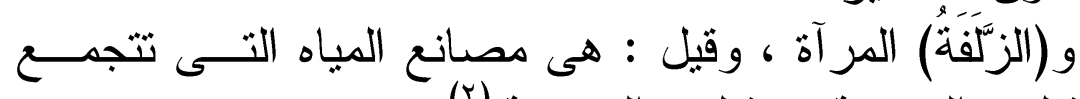

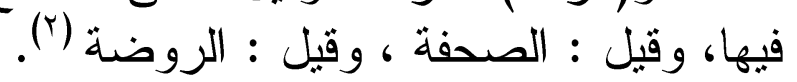

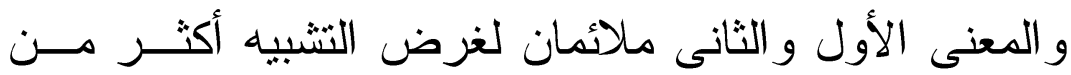

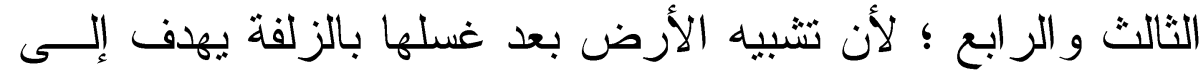
بيان حالها من النظافة و الصفاء على وجه يفيد المبالغة و التأكبــد كما هو الحال فى كل تشبيه - فالأرض تصبح بعد غسـلـل المطــر

(1) راجع : أسرار البلاغة للإمام عبدالقاهر صـــ ا تحقيق الثيخ/ محمود محمد شــاكر

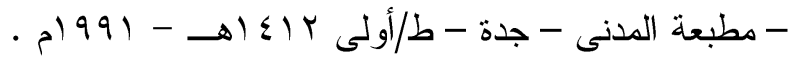

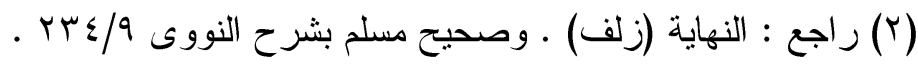




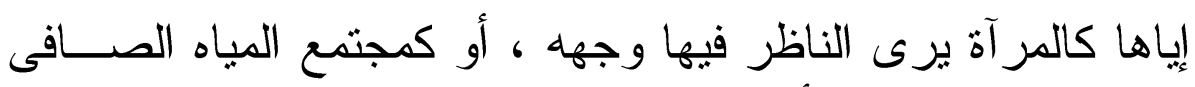

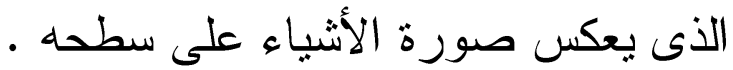

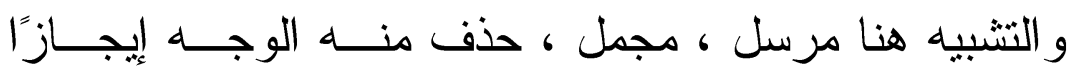
واختصارًا ، ولتذهب فيه كل نفس المذهب الذیى تر اه أمس رحمًّا

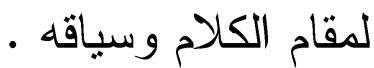

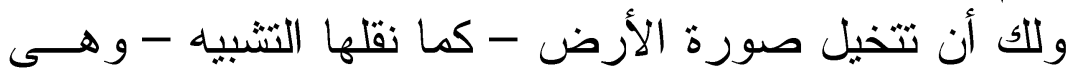

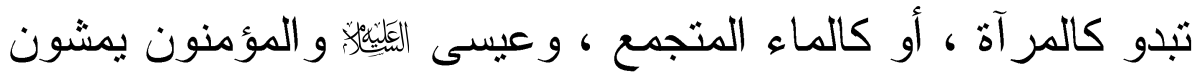

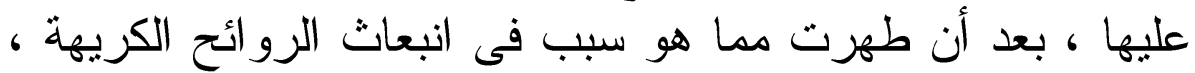

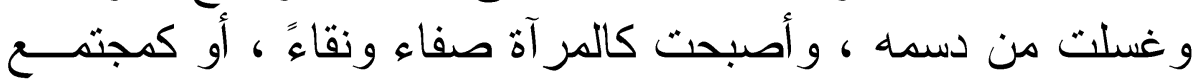
الماء عكسًا لصورة من ينظر فيه ـ ولهيه

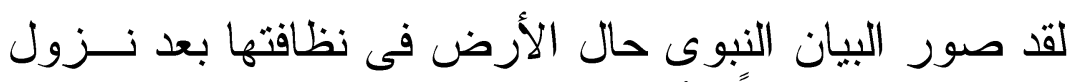

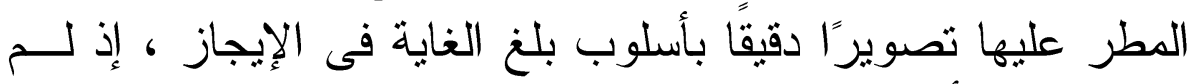
يتطلب من الألفاظ إلا ثيلاثة . 


\section{هلول البركة فى كل شئ قبل قبض المؤهنين}

\section{9 \\ قيام الساعة على شرار الظلق}

بعد تطهير الأرض من جثت يأجوج ومأجوج وما تبقى مسن

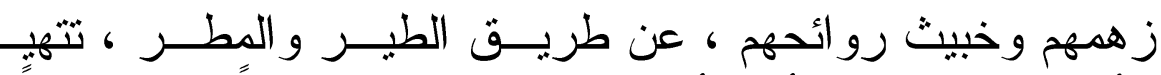

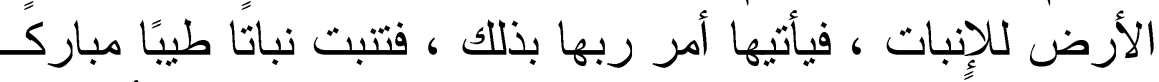

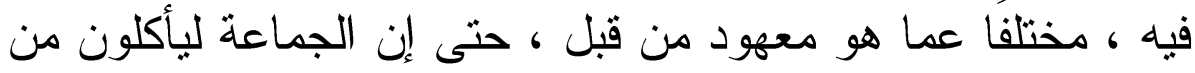

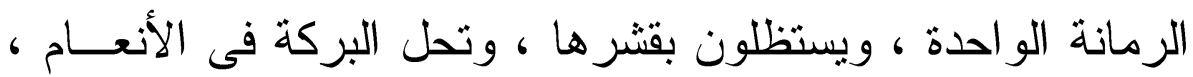

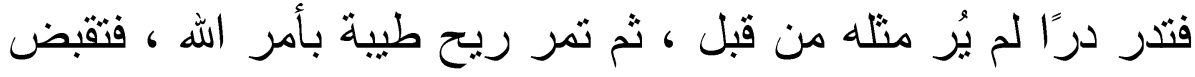

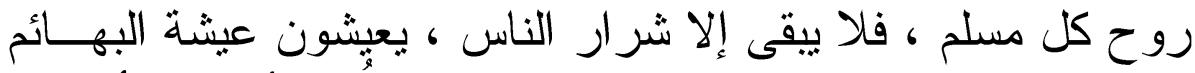

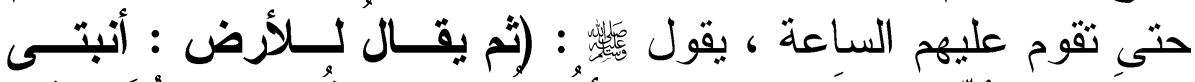

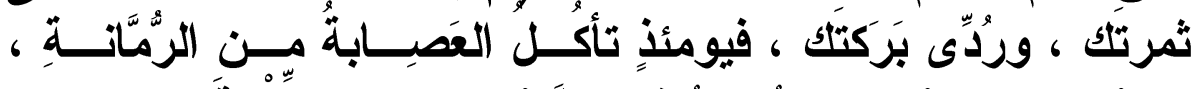

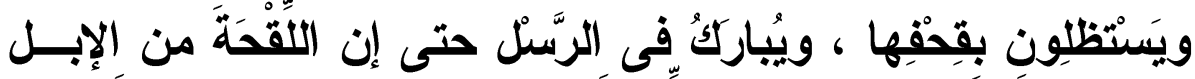

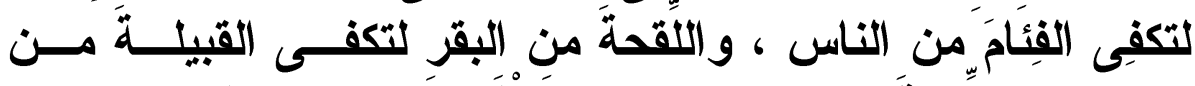

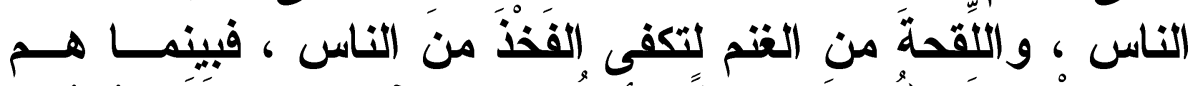

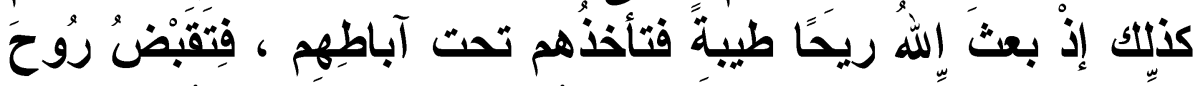

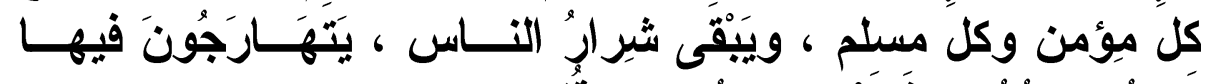

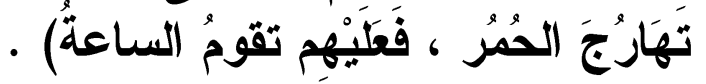

ويبدأ النظم الثريف هذا الجزء بحرف العطف (ثم) و الــذى الإلى

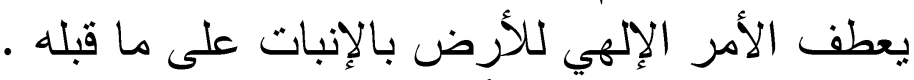

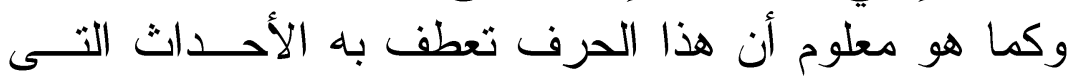

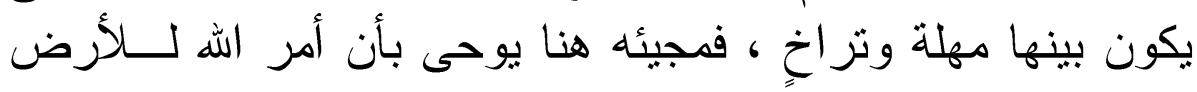


بالإنبات يكون بعد غسل المطر إياها بفتزة تثيح لسطحها أن يجـــ

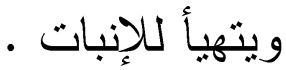

ثم يجرى النظم الثريف على ما تقتضيه البلاغة فى صياغة

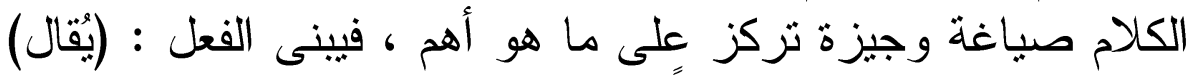

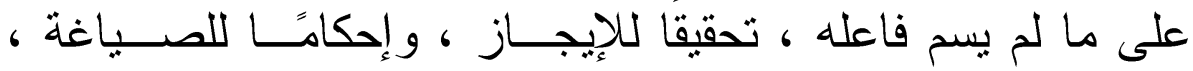

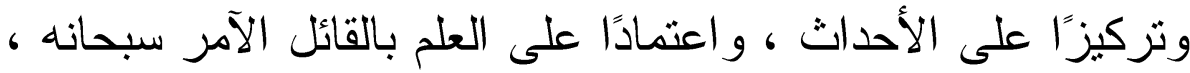

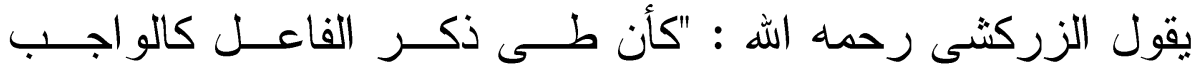

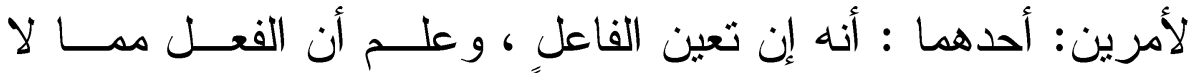

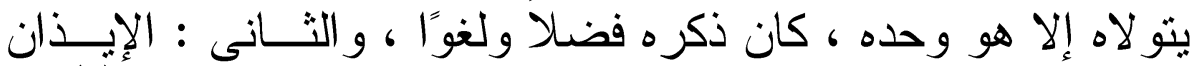

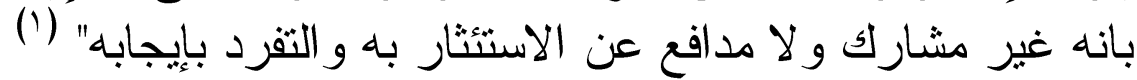

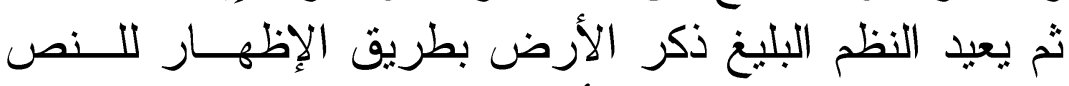

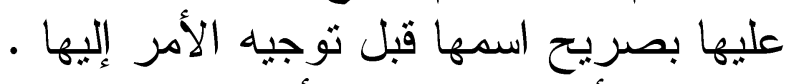

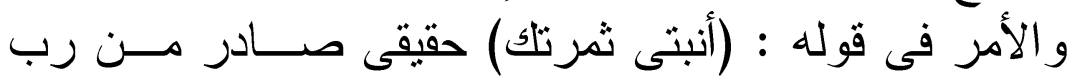

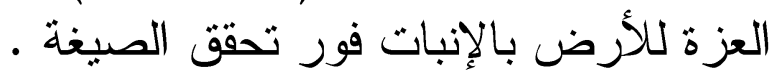

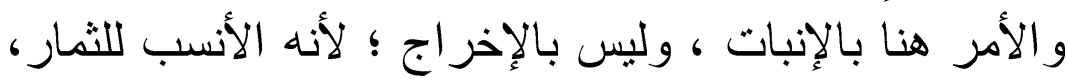

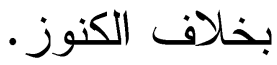

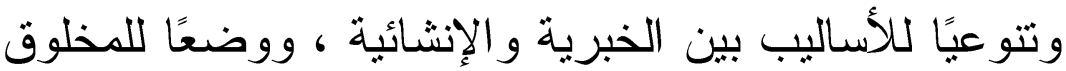

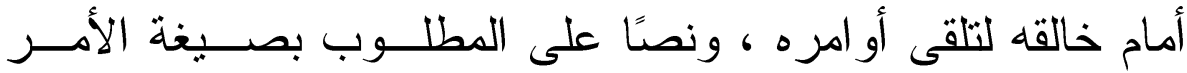

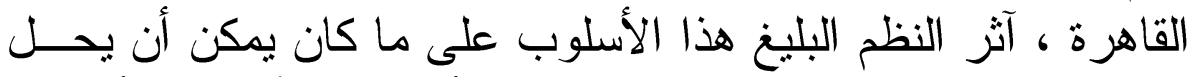

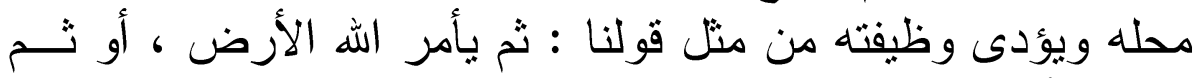

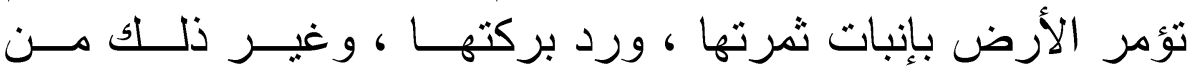

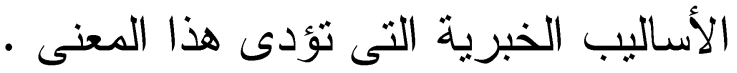

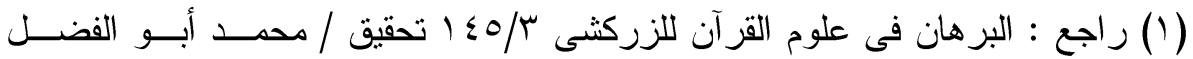

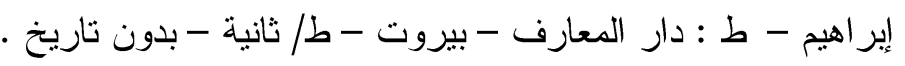


و المالاحظ هنا تعدى الأمر بالإنبات إلى الثمار ، وليس إلـى

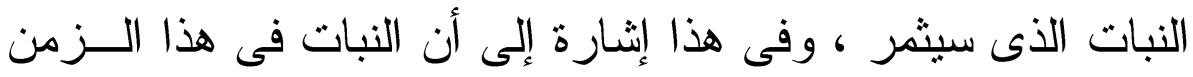

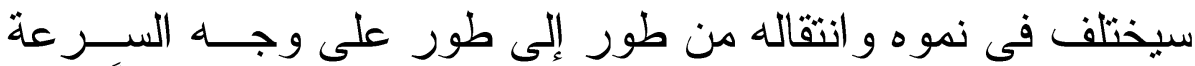

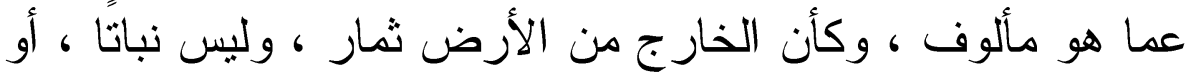

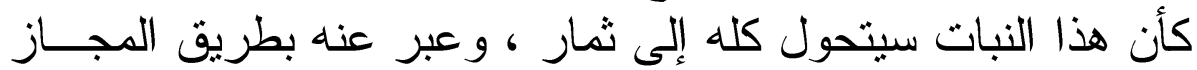

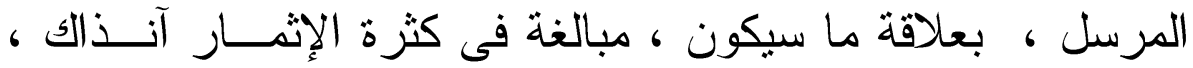

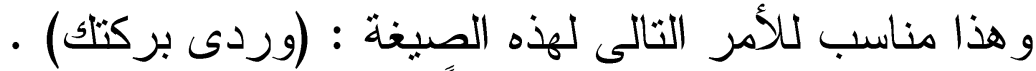

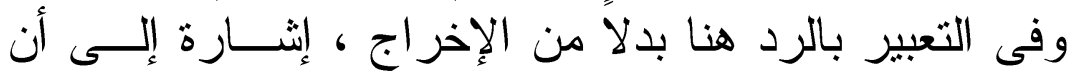

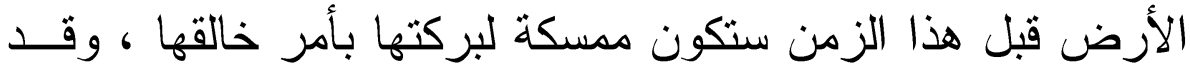

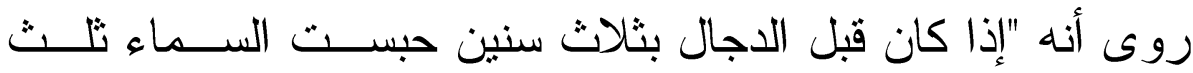
قطر ها وحبست الأرض ثلث نباتها ، فإذا كانت السنة الثانبة حبست السماء ثلثى قطر ها وحبست الأرض ثنثى نباتها ، فإذا كانت الســنة الثالثة حبسث السماء قطر ها كله وحبست الأرض نباتها كله ..."(1).

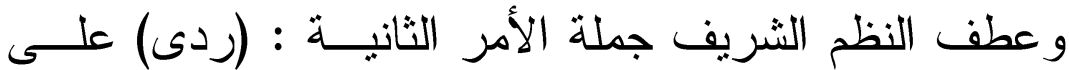

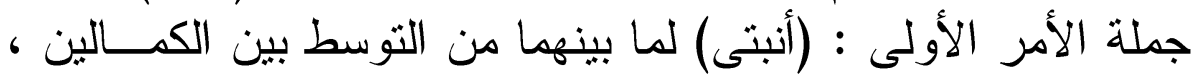

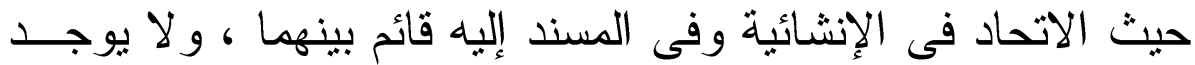

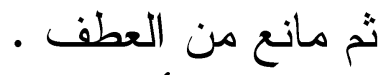
وقد أحدث ختامٍ الجملتين بروى و احدٍ ، مع اتحاد الفاصلتين

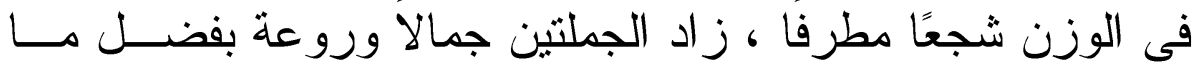

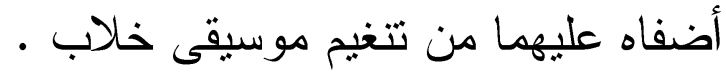

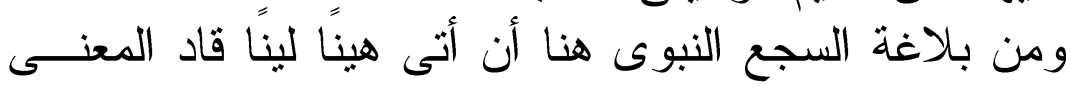

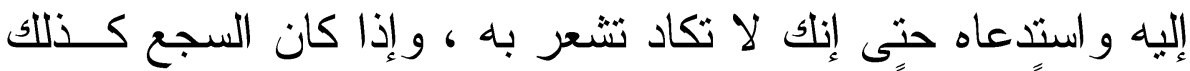
كان حسنا مقبو لا ، يقول ابن سنان رحمه الله : "و المذهب الصحيح

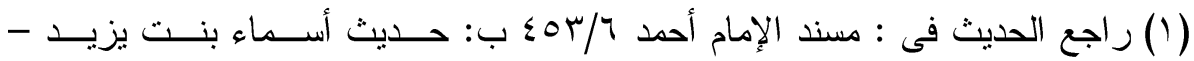
رقم:9VT 
أن السجع محمود إذا وقع سهلاً متيسرًا بلا كلفة و لا مشقة ، وبحيث

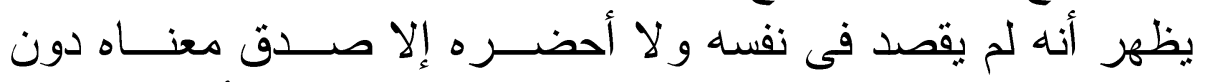
مو افقة لفظه ، و لا يكون الكلام الذى قبله إنما يتخيل لأجله ، والا وورد

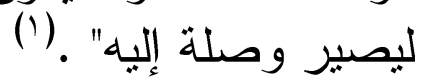

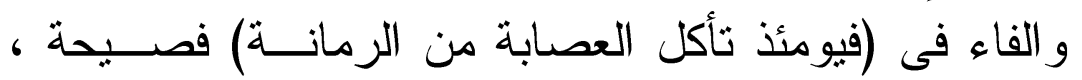

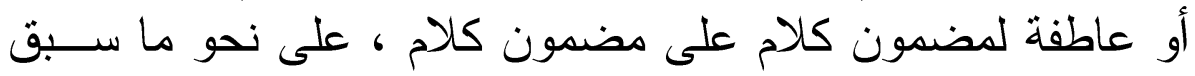

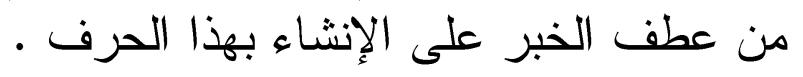

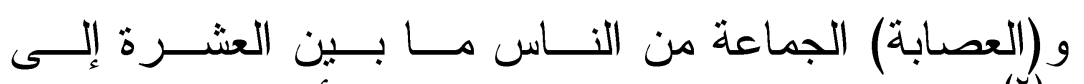

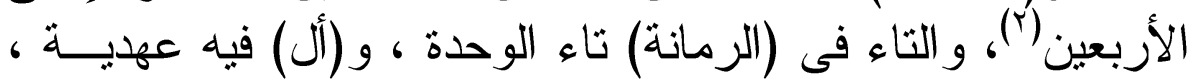

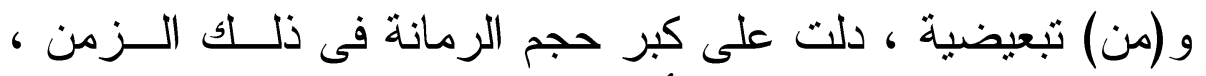

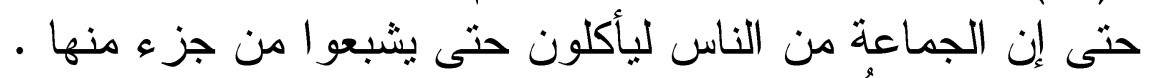

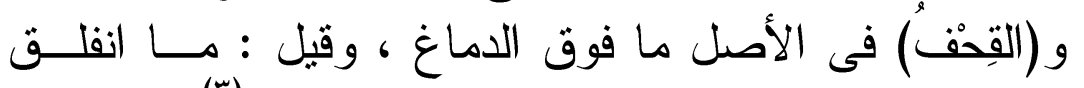

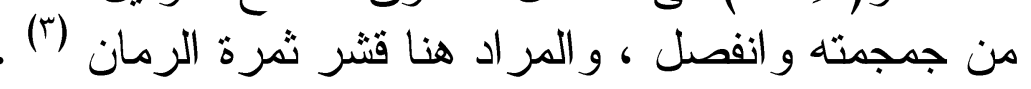

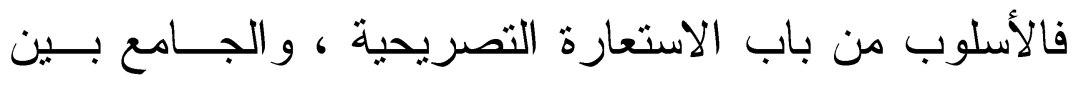

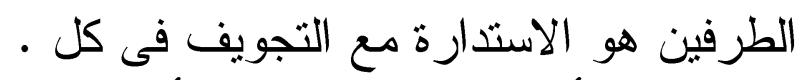

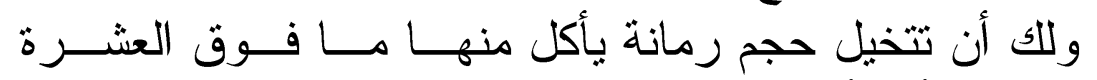

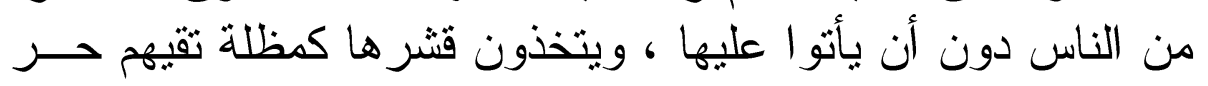

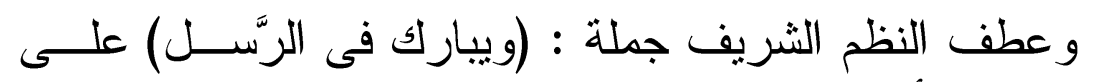
جملة : (يقال للأرض) لما بينها من التوسط بين الكمالين ، ويجوز

(1) راجع : سر الفصاحة لابن سنان الخفاجى / W/ ط ط : دار الكتب العلمية - بيروت

$$
\begin{aligned}
& \text {. }
\end{aligned}
$$

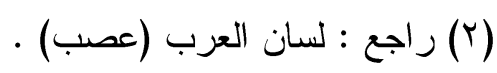

$$
\begin{aligned}
& \text { (ب) راجع : النهابة (قحف) }
\end{aligned}
$$




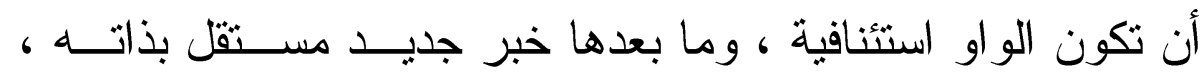

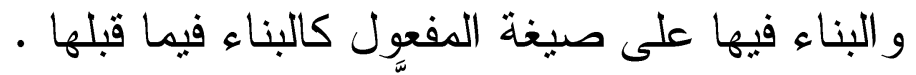

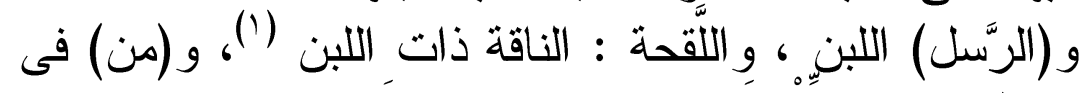
قولِهِ

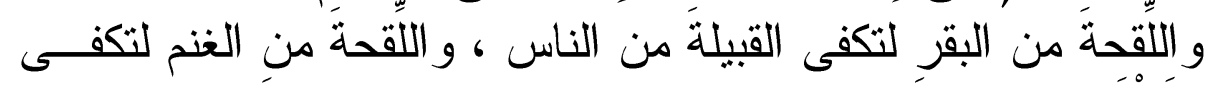

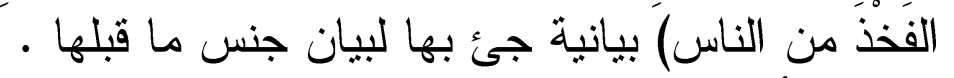

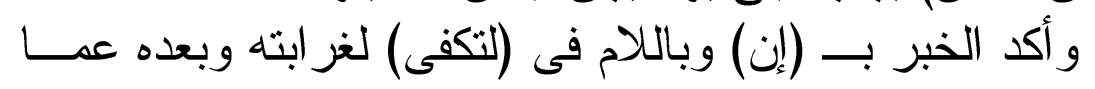

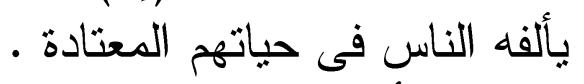

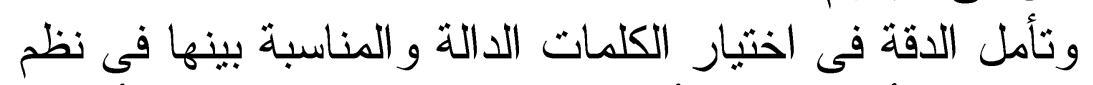

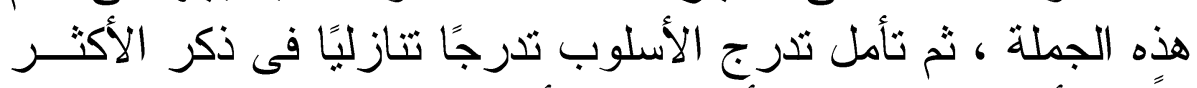

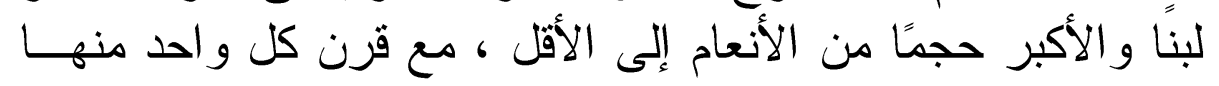

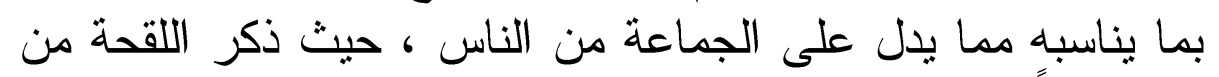

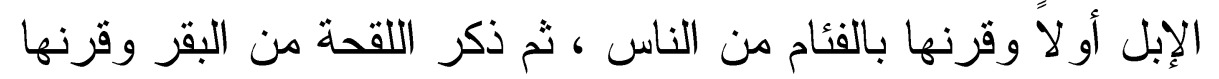

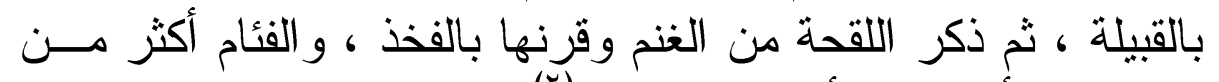

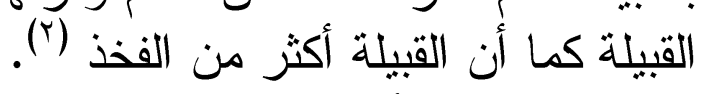

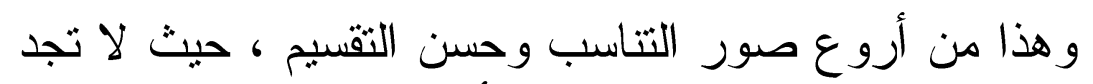

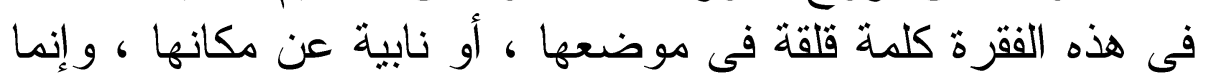

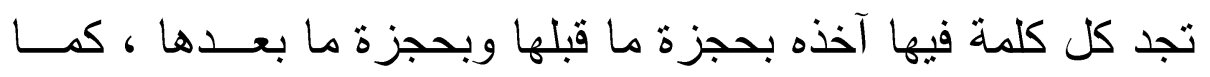

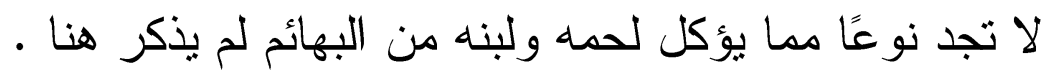

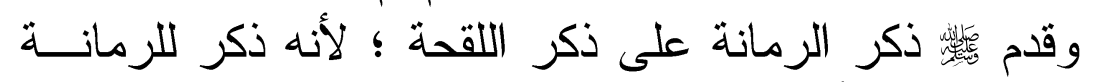

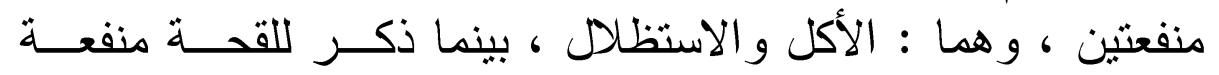

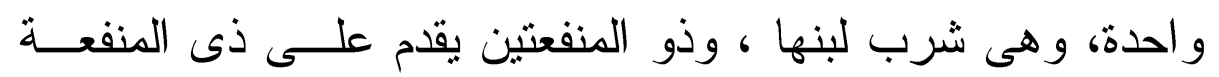

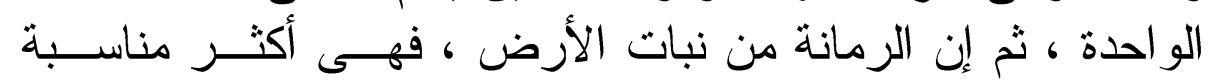

$$
\begin{aligned}
& \text { (1) راجع : النهاية (رسل) . }
\end{aligned}
$$

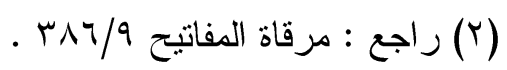




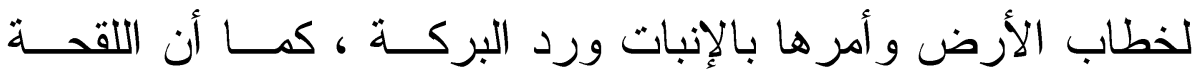

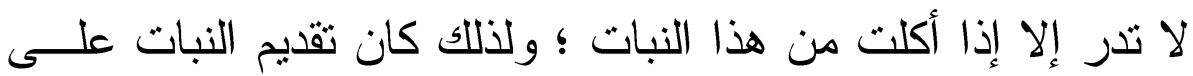

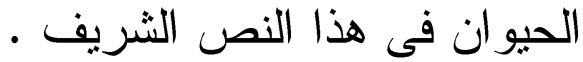

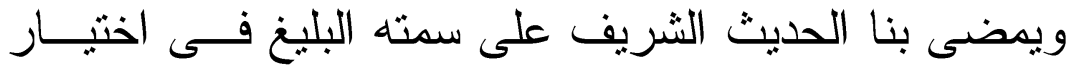

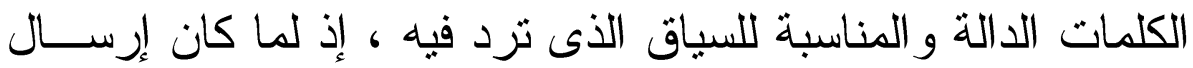

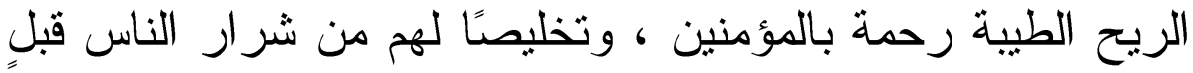

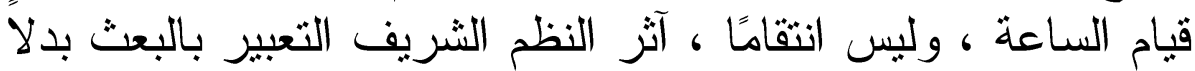

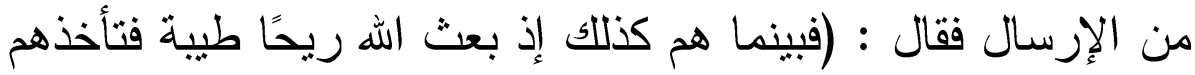
تحت آباطهم ، فنقبض روح كل كل مؤمن وكل مسلم).

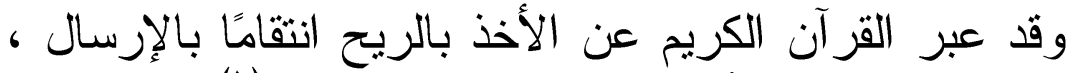

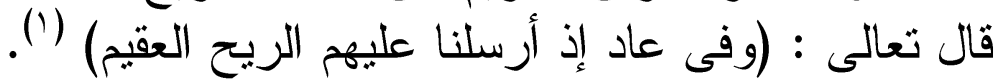

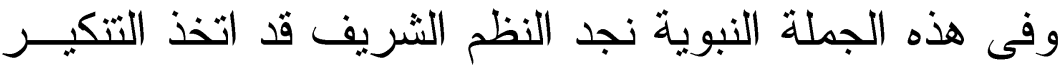

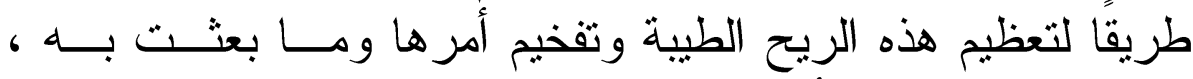

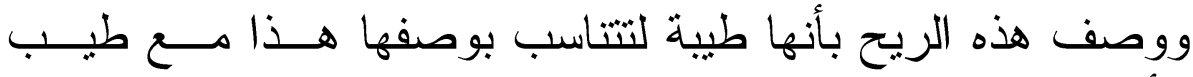

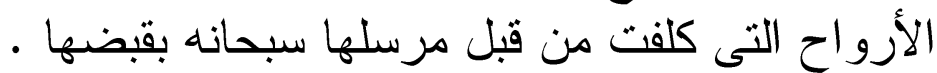

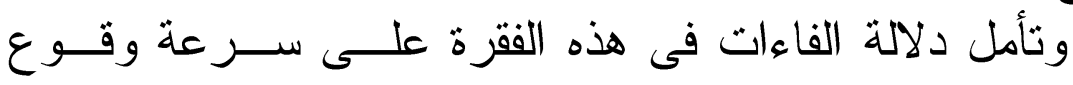

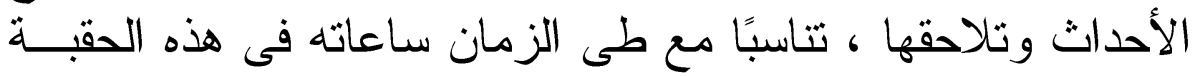

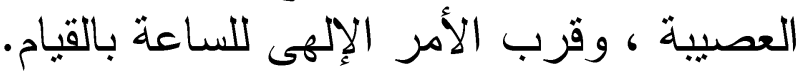

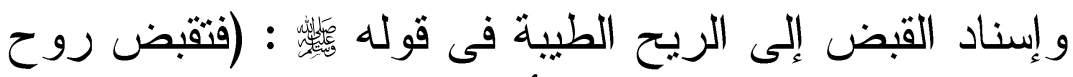

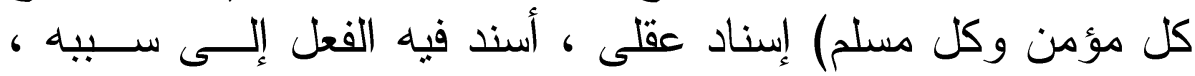

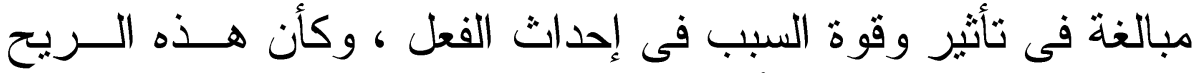

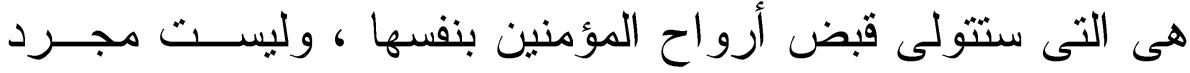
سبب فيه . 


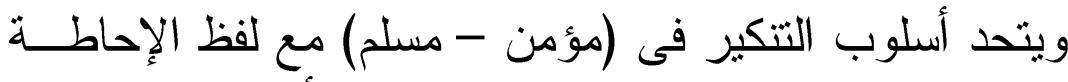

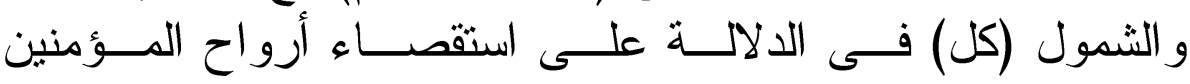

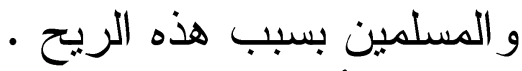

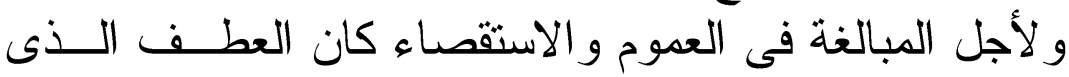

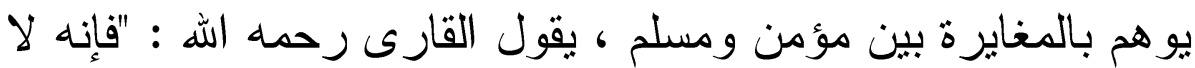

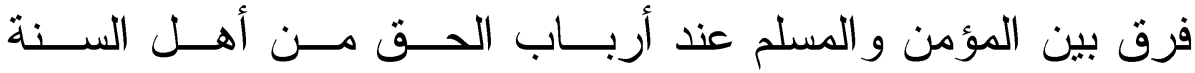

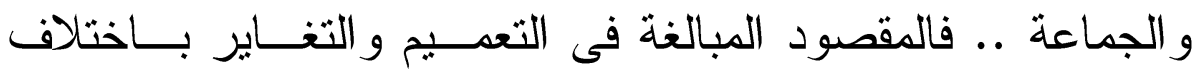

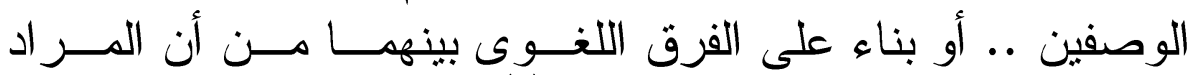

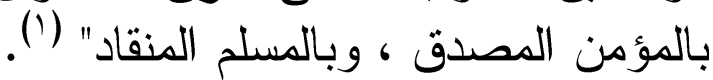

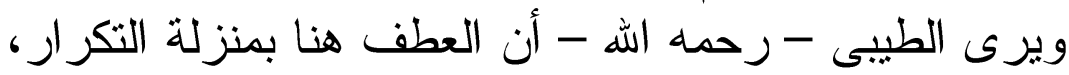

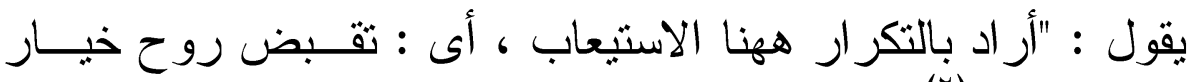

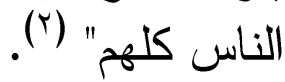
و الو اوفى قوله عليه الصـلاة و السلام : (ويقى شرار النـاس

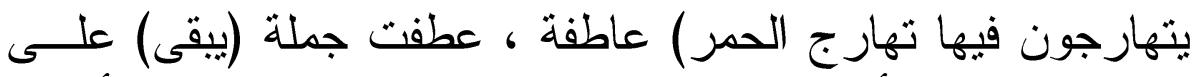

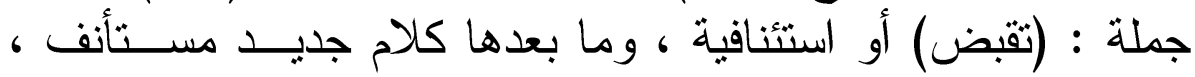
أو حالية .

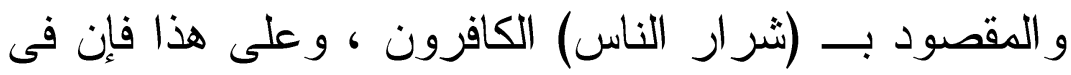

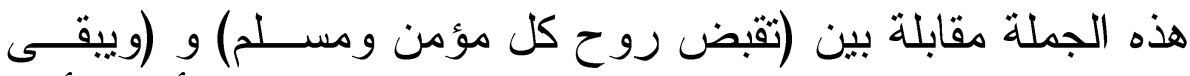

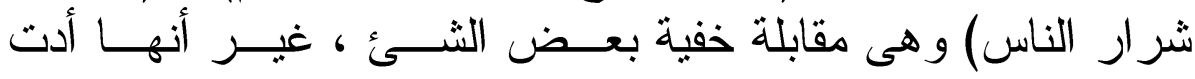

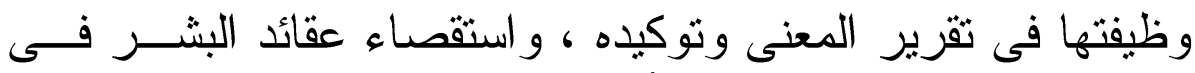
ذلك الزمن وحالهم من الموت أو البقاء.

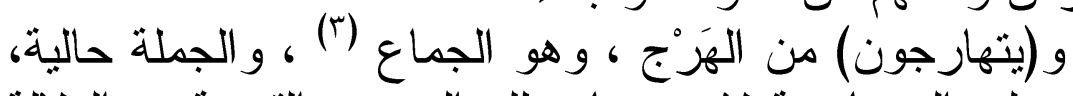
صيغت على المضار عة لاستحضار تلك الصورة الصناع القبيحة ، و الدلالة 
على تجدها و استمر اريتها ، إثنارة إلى أن هذا الفحش سيقع مــنهم

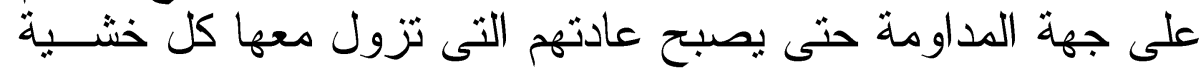
وحياء.

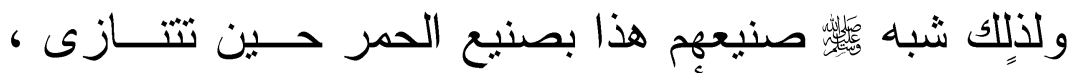

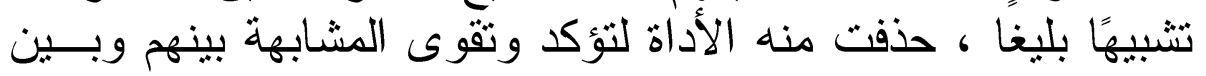

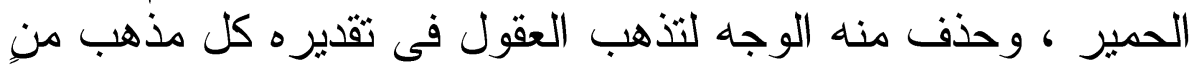

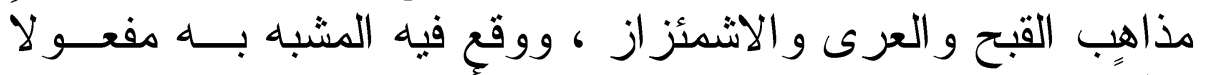

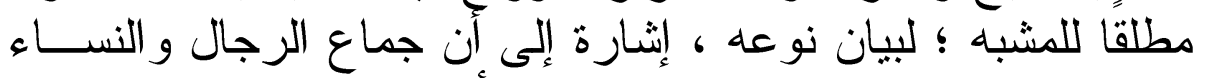

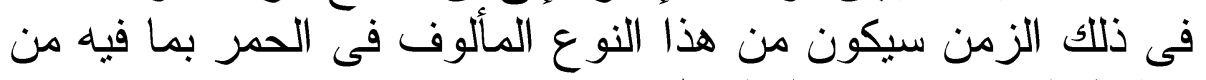

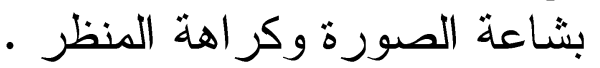

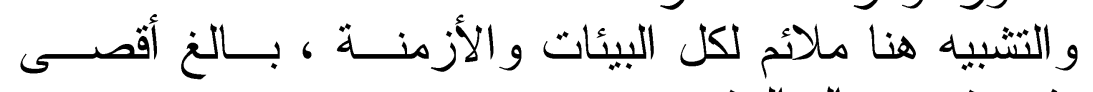

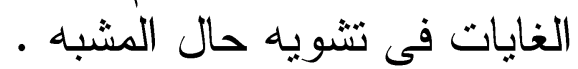

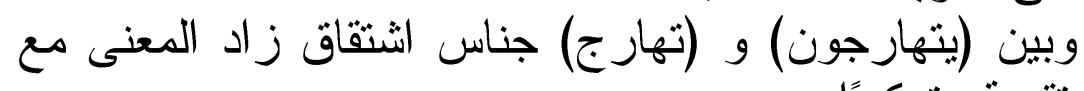
التشبيه تقوية وتوكيدًا .

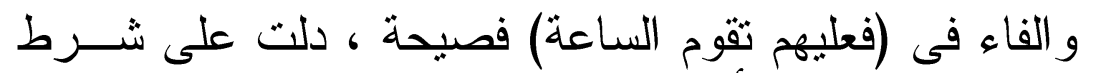

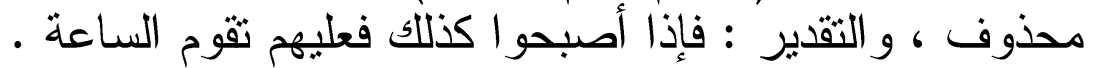

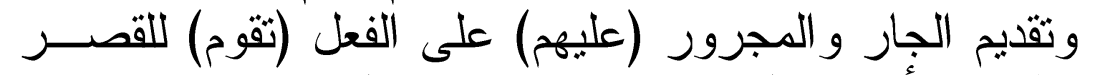

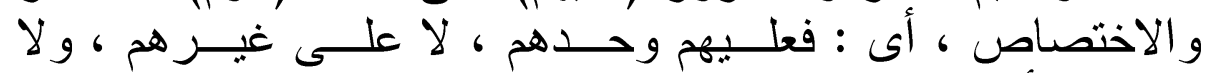

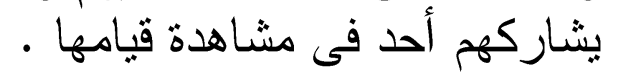

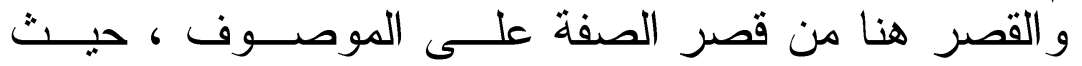

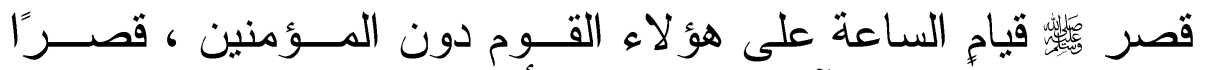

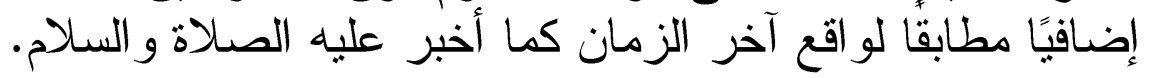

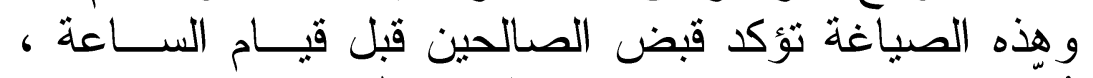

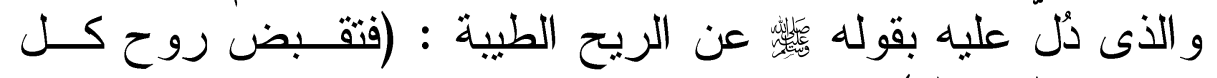
مؤمن وكل مسلم).

وصل اللهم وسلم على سيدنا محمد ألمدين وعلى آله وصحبه أجمعين 


\section{خاتمهـة البحـــث}

الحمد الله رب العالمين ، و أصلى وأسلم على خاتم الأنبيـــاء و المرسلين ، سيدنا محمد ، و على آله وصحبه و التابعين .

\section{وبندــ}

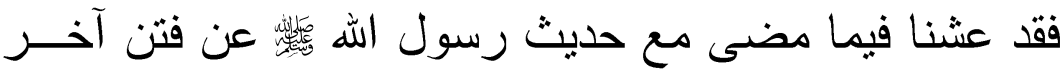

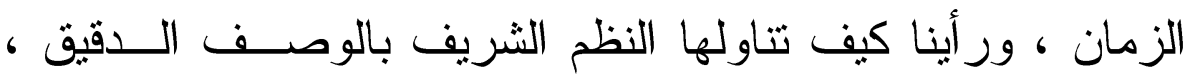
و التصوير الكاشف ، و الأسلوب الوجيز ، و العبارة الو اضحة . وقد انتهينا من خلال هذه الارسة إلى النتائج التالية :أولاًا : اتسام ألفاظ ومعانى الحديث الشريف بالفصاحة و الوضوح .

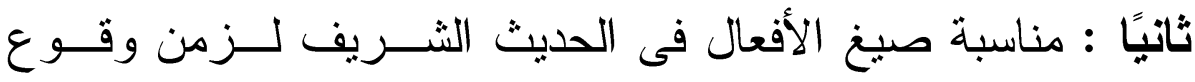
الأحداث ، حيث جاءت على صيغة المضار عة ، إلا قوله له

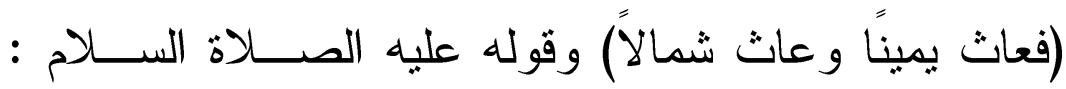
(إذ بعث الله عيسى ابن مريم) وقوله : (إذ أوحسىى الله إلـى • عيسى)

ثالثًا : حرص البيان النبوى على إخراج هذه الحقائق الغيبية التـى اشتمل عليها فى صورة مقررة محققة ، وذلك مسن خــلال إل استخدام بعض أساليب التوكيد . 
رابعــا: اعتماد البيان النبوى في هـــا الحــديث الثــريف علــى الأسلوب الخبرى أكثر من الأسلوب الإنشائى ؛ وذللك لأن

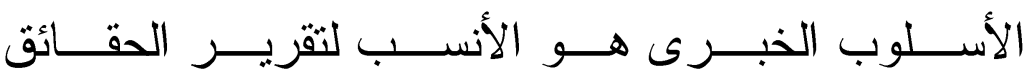

الغييية الدقطوع بوقوعها بعيدًا عن الإثارة و التهييج. خامسًا : ميل الأسلوب فى هذا الحديث الشريف إلى الإيجاز الثديد

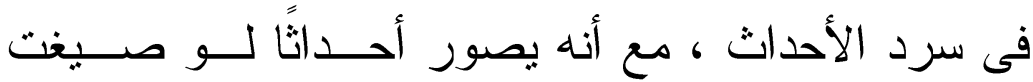
بطريق التفصيل لاحتاج الوفاء بها إلى أضعاف هذا النص النص

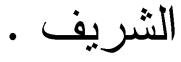
سادسًا : استخدام البيان النبوى فى هذا الحديث الشريف لأسـاليب التشبيه ، و المجاز ، و الكناية ، لإيضاح بعـض النس الدعـانى وتقريرها ، وعرضها في صورة محسوسة مألوفة .

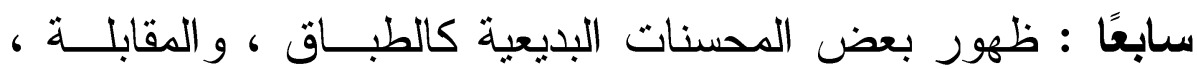
ومر اعاة النظير ، و الجناس ، والسجع ، بصورة عفوية قاد إليها المعنى و استخعاها دون تكلف ، و هذا ما يجعل قـارئ الحديث لا يكاد يشعر بوجودها .

وآخر دعوانا أن الحمد الله رب العـالمين - - مان 


\section{المصادر والمراجع}

1- إخر اج الكلام على خلاف مقتضى الظاهر د/ إبر اهيم داود

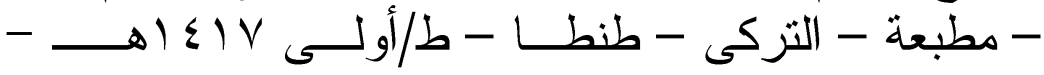
.1997

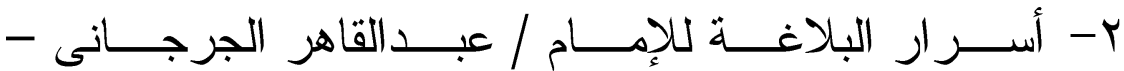

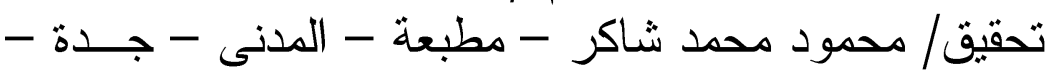

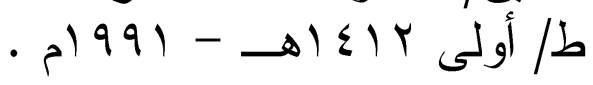

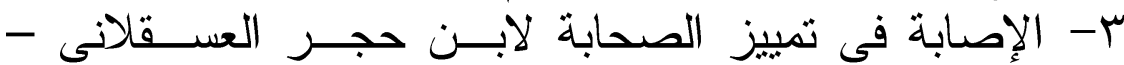

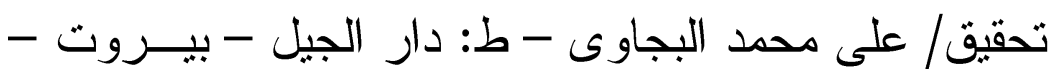

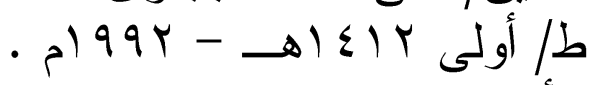

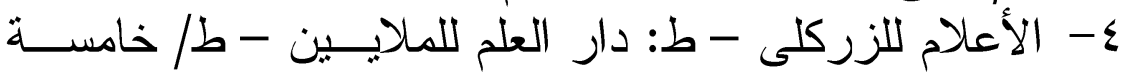

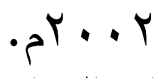

0- إكمال إكمال المعلم للأبى هع مكمل الإكمال للسنوسـى -

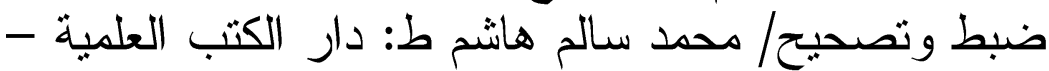

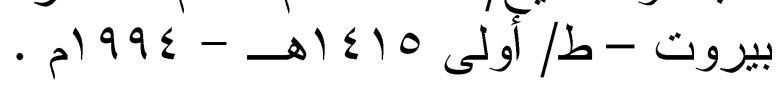

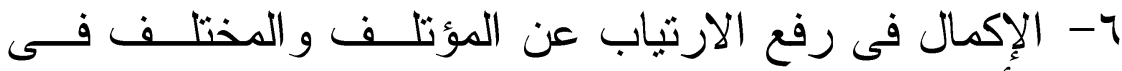

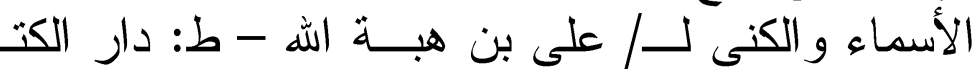

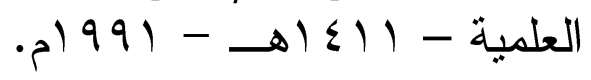

-V

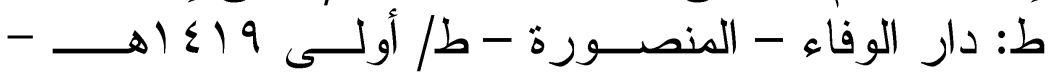

$$
\text { - } 991
$$

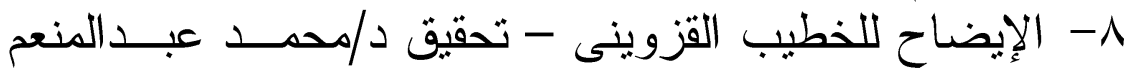

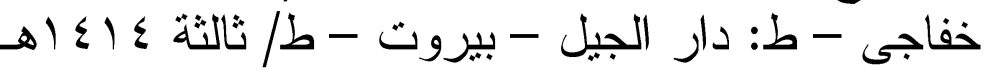

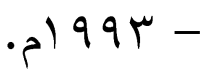

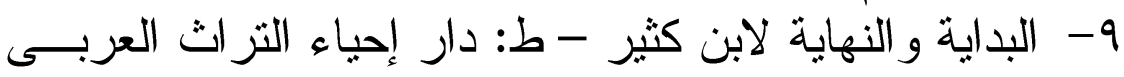

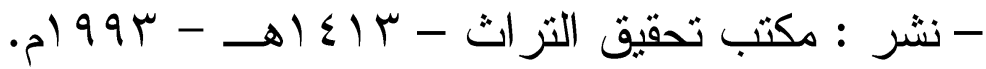




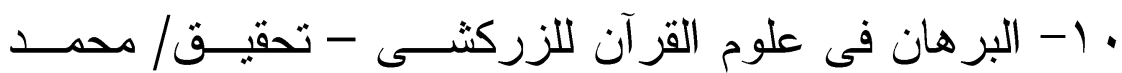

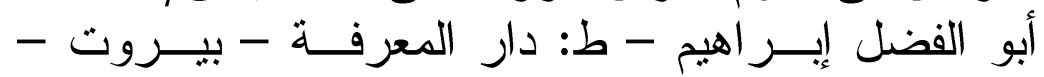
طا ثانية - بدون تاريخ.

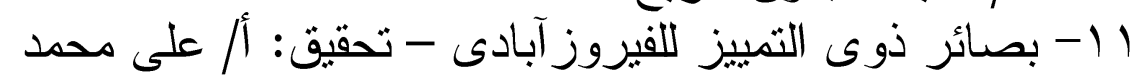

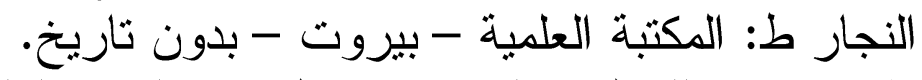

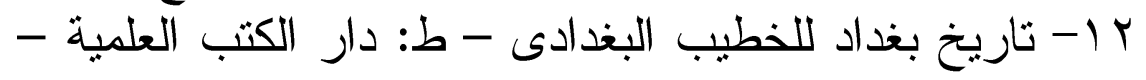

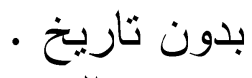

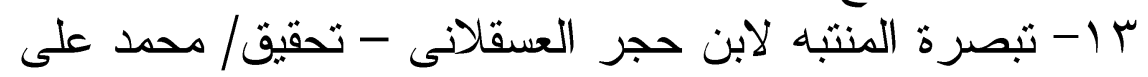

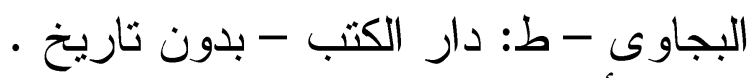

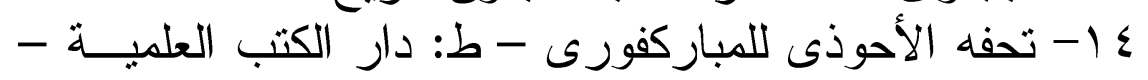
بدون تاريخ.

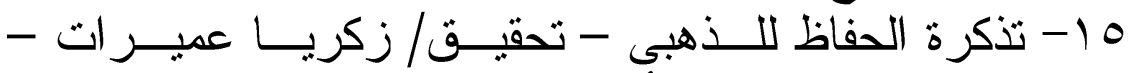

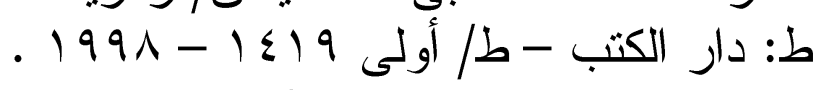

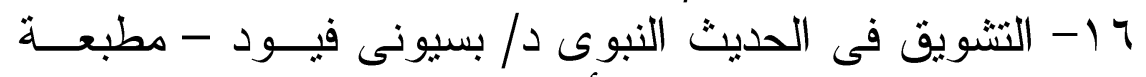

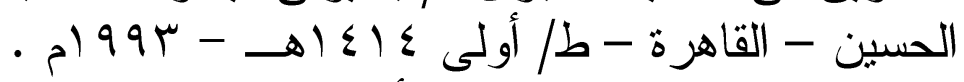
IV

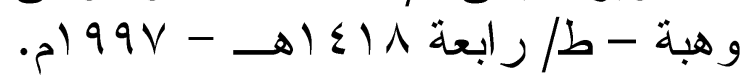

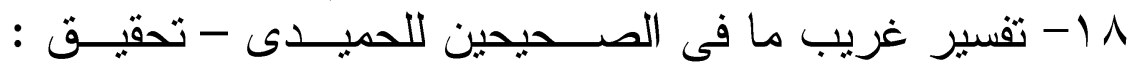

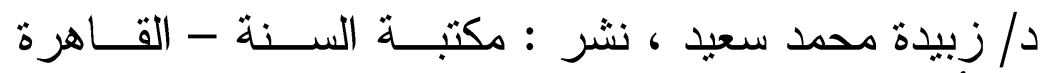

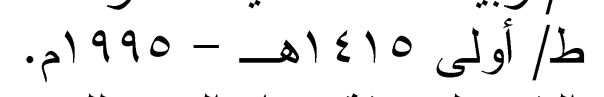

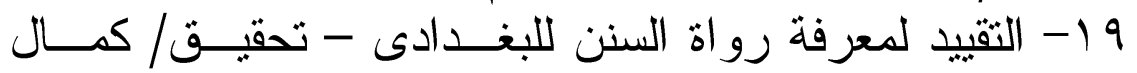

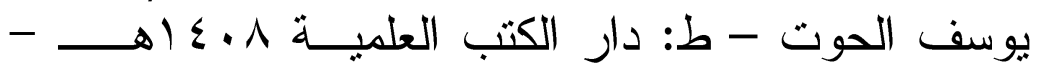
- 911

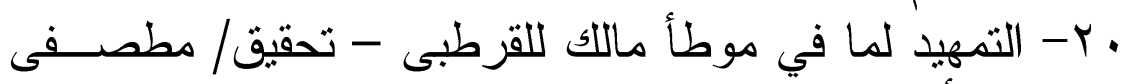

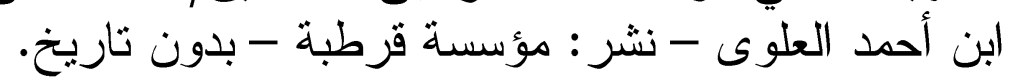
ا اY- تهذيب التهذيب لابن حجر العسقلانى - مطبعة : دائـــرة

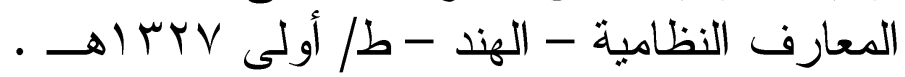




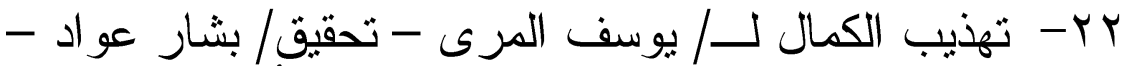

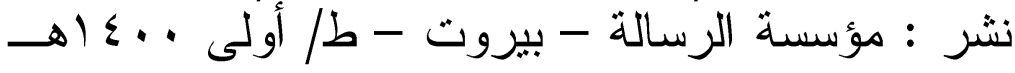

$$
\text { - } 919 .-
$$

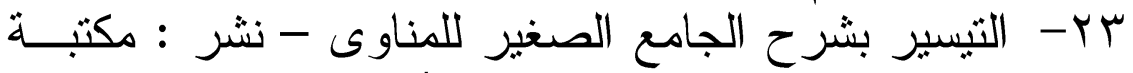

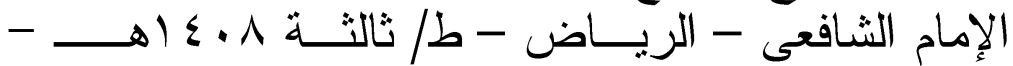

$$
\text { - } 911
$$

ع ؟- الثقات لابن حبان - تحقيق/ السبد شرف الدين - ط: دار

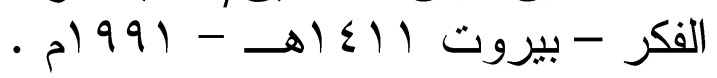

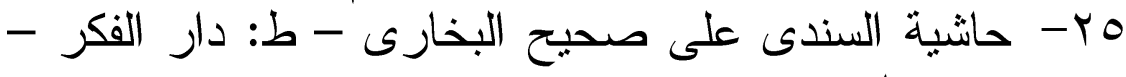

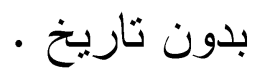

ب ب- الحديث النبوى الثريف من الوجهة البلاغية د/ عز الدين

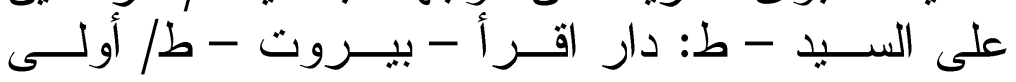

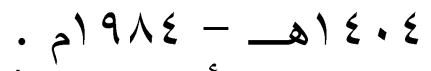

- YV

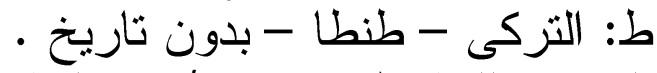

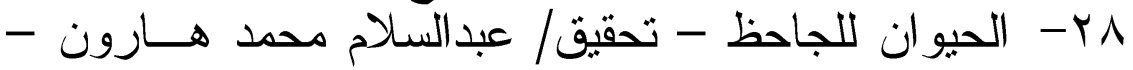

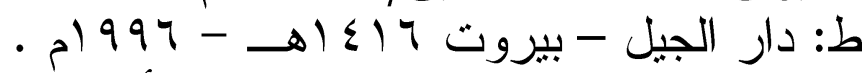

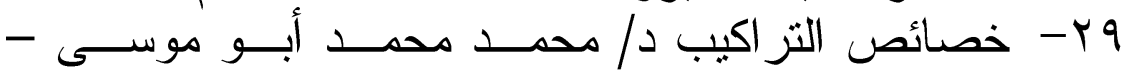

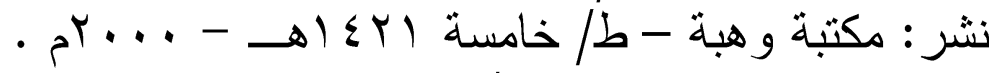

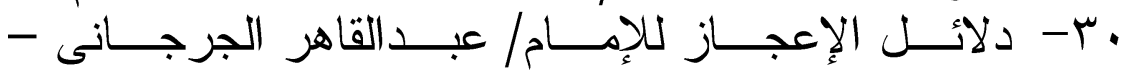

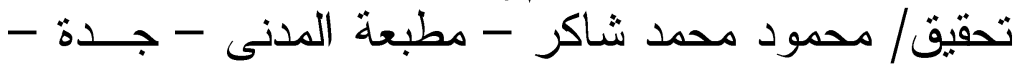

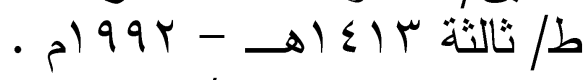

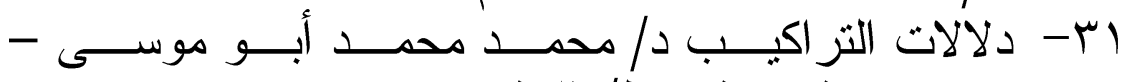

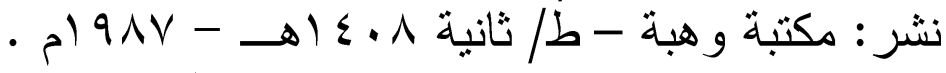

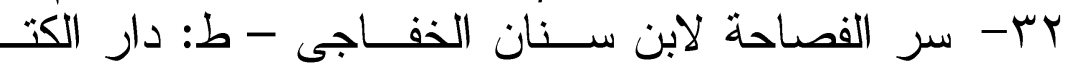

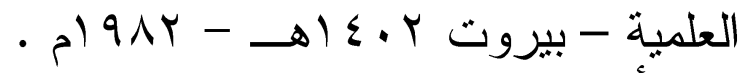

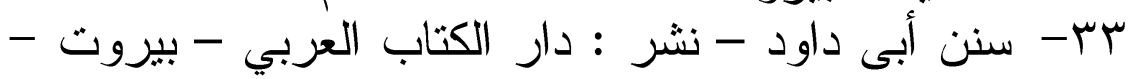
· بدون تاريخ ل 


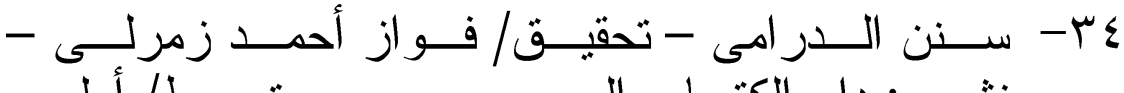

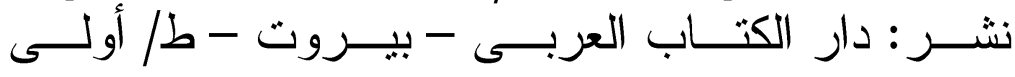

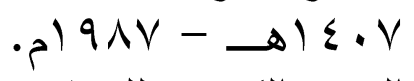

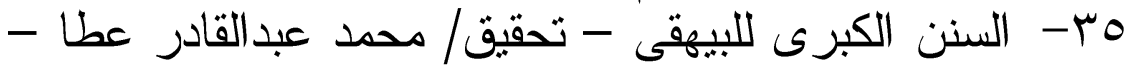

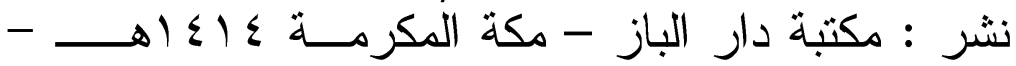

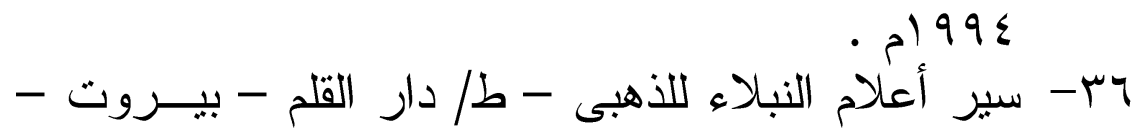

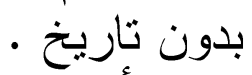

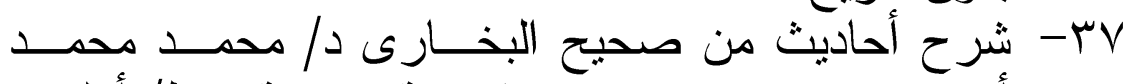

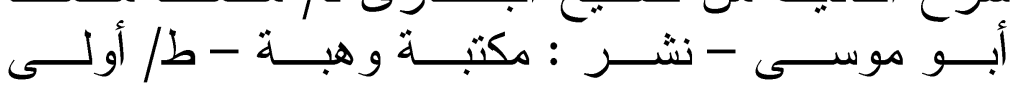

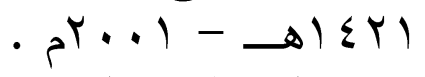
مب- شرح الزرقانى على موطأ مالك - طا دار الكتب العلمية

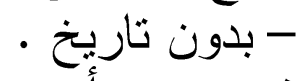

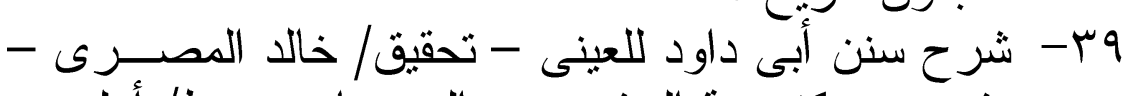

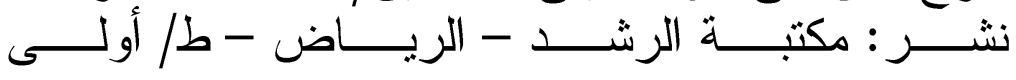

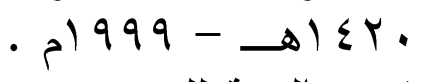

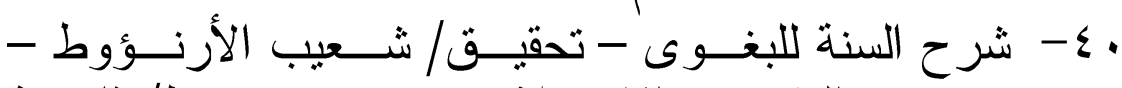

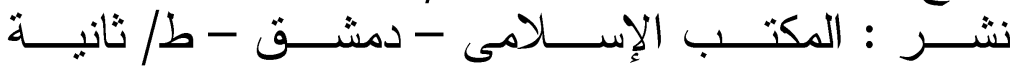

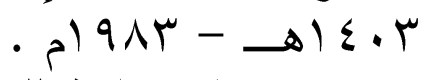

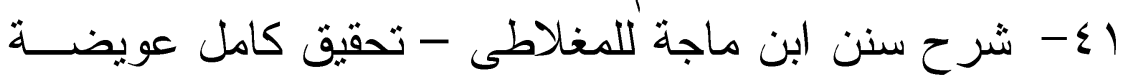

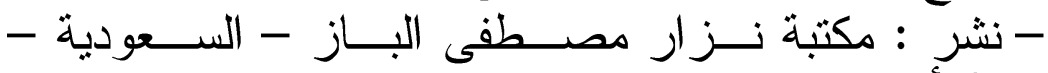

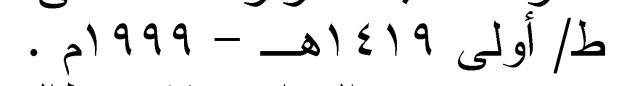
r

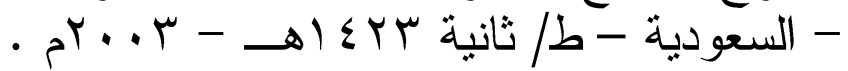

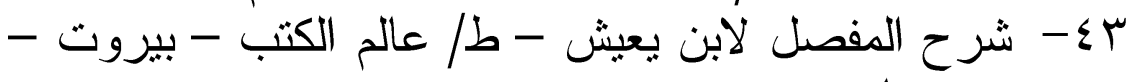
• بدون تاريخ ؟ - شروح التلخيص - طاردار الإرشاد الإسلامى- بيروت •بدون تاريخ 


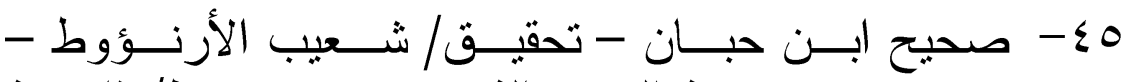

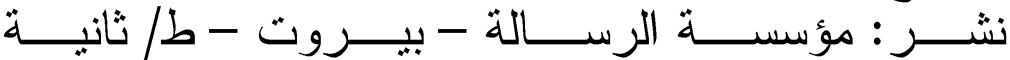

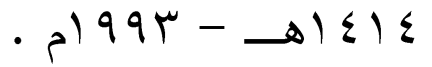

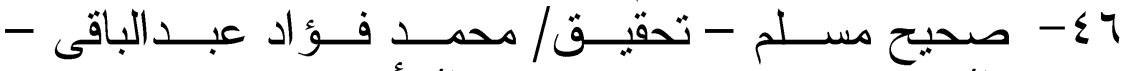

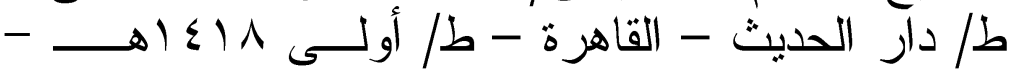

$$
\text { - م) } 99 \mathrm{~V}
$$

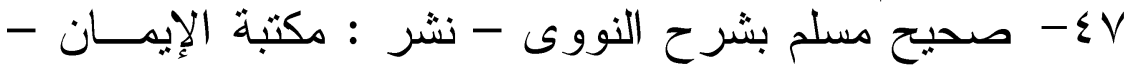

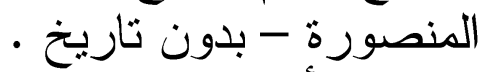

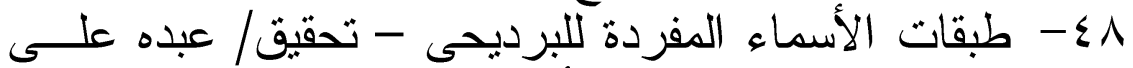

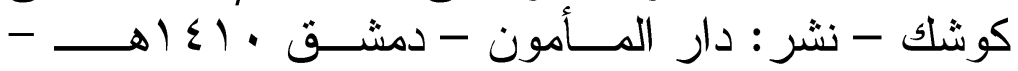
. 99 .

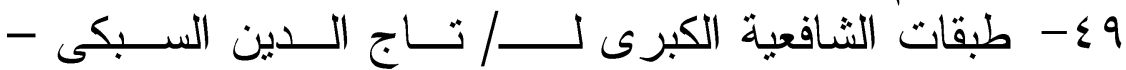

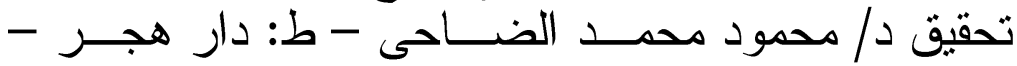

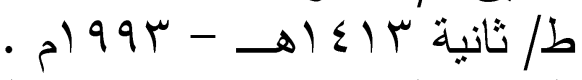

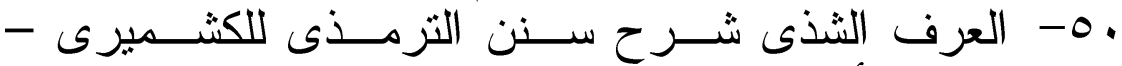

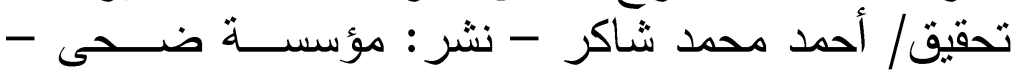

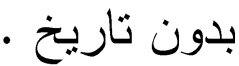

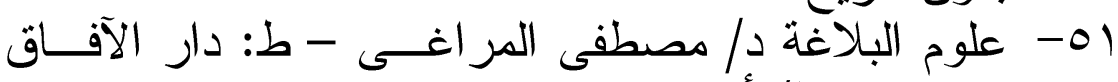

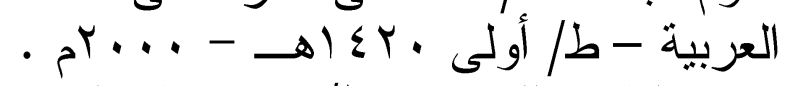

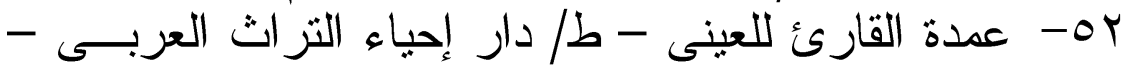
• بدون تاريخ الفئ

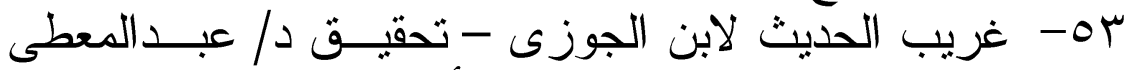

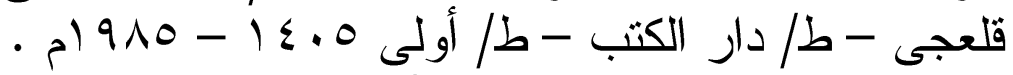

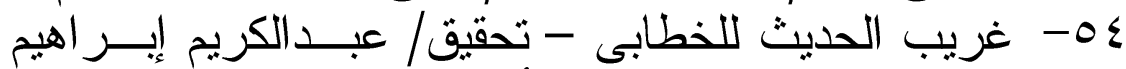

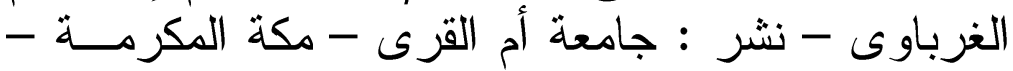

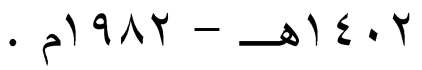

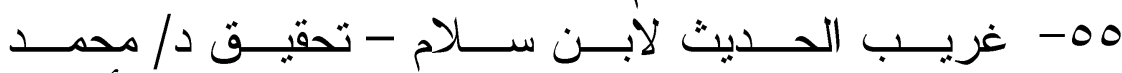

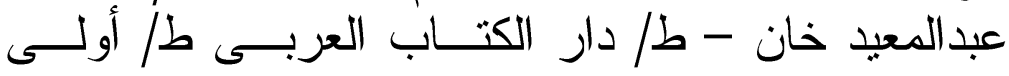

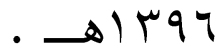




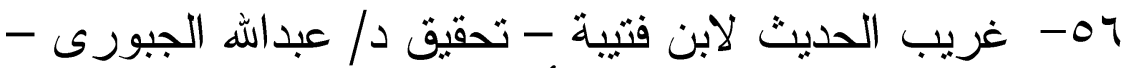

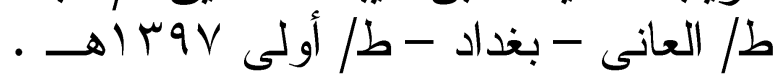

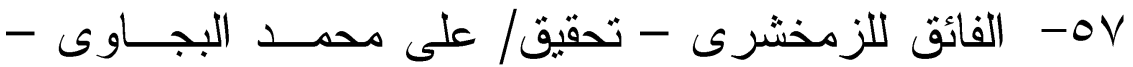

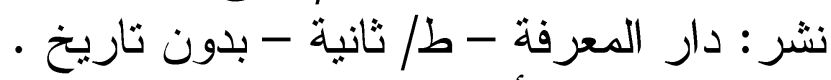

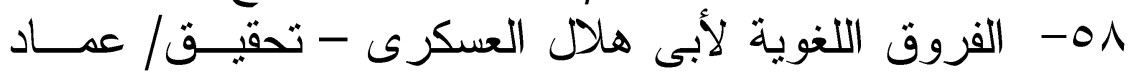

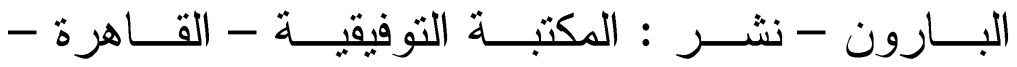
بدون تاريخ.

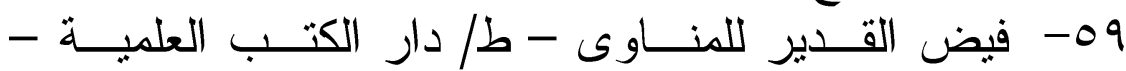

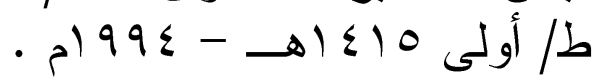

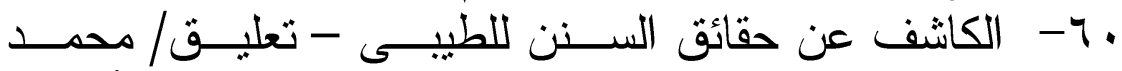

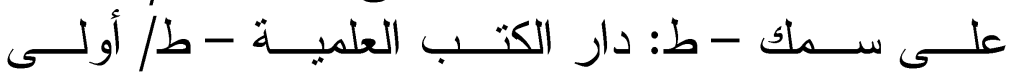

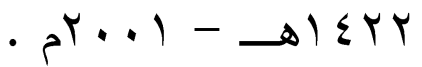

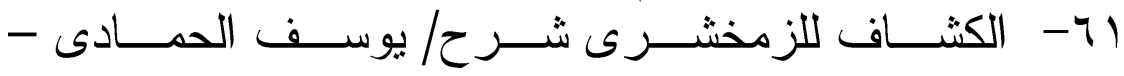

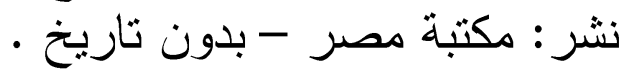

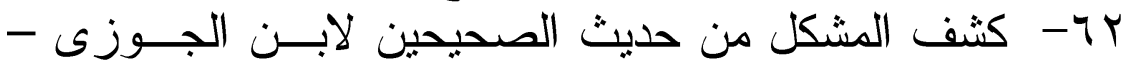

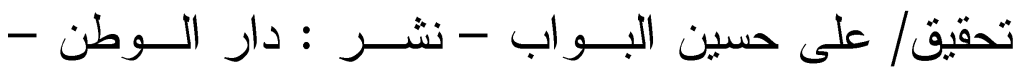

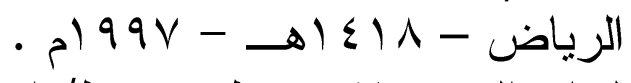

سج- لسان العرب لابن منظور - طادار الحديث - القاهرة -

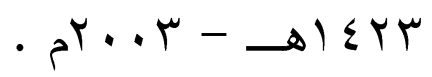

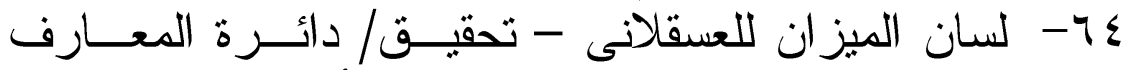

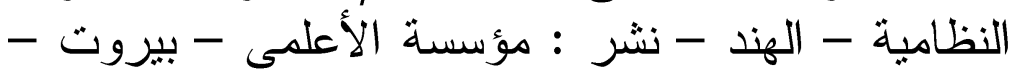

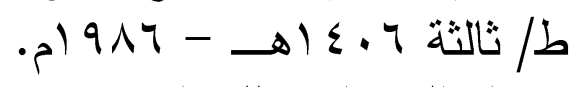

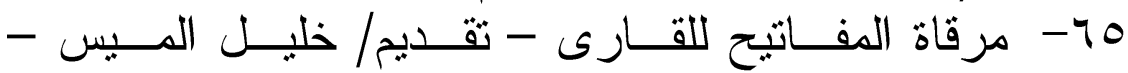

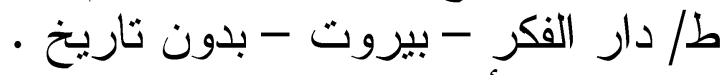

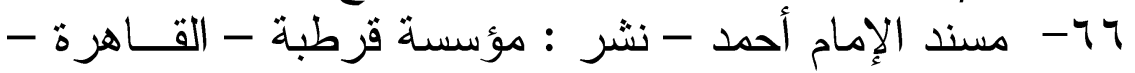

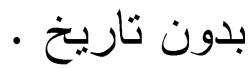




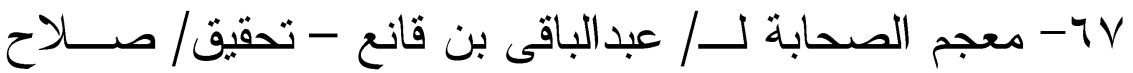

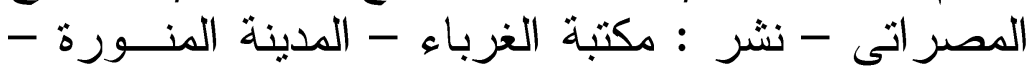

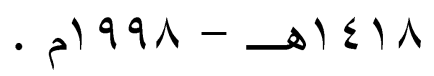

1 • تاربخ

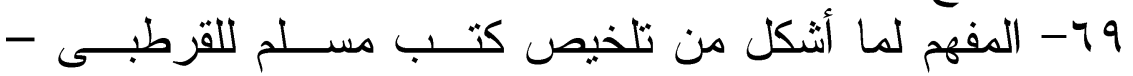

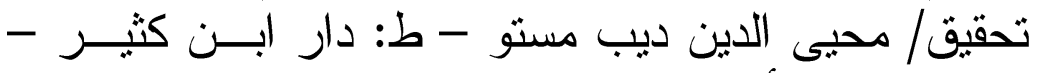

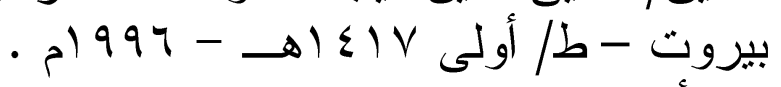

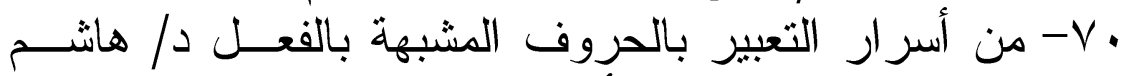

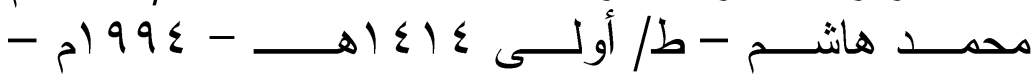

بدون نشر

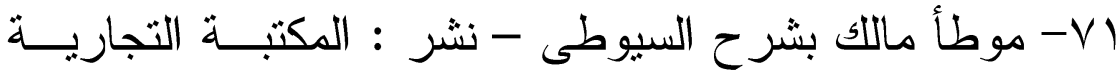

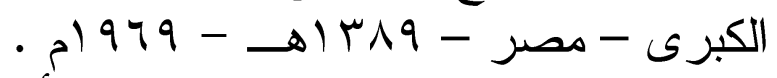

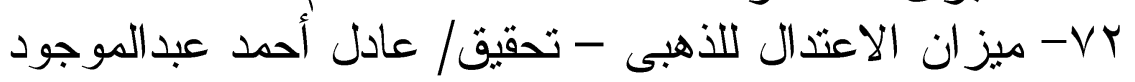

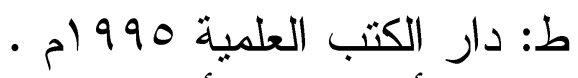

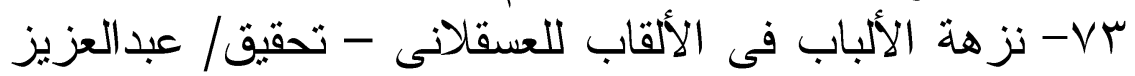

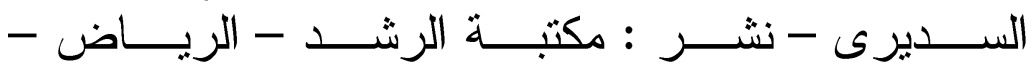

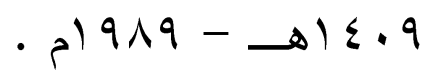

ـ - النهاية فى غريب الحديث و الأثر لمجد الدين بن الأثير

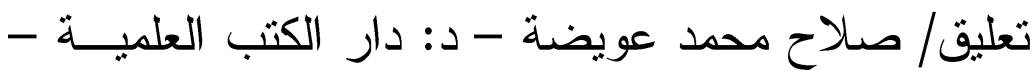

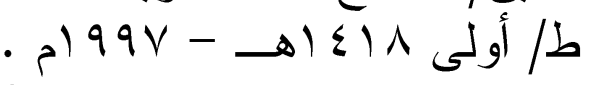

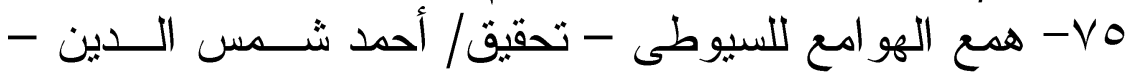

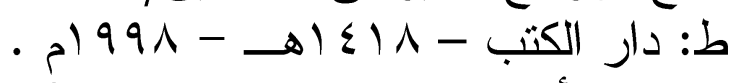

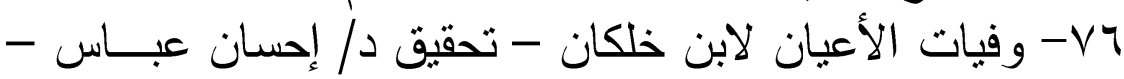

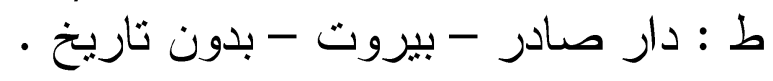

